\title{
The Impact of Teen Magazines on Adolescent Girls in North Cyprus
}

\section{Yonca Aybay}

Submitted to the

Institute of Graduate Studies and Research

in partial fulfillment of the requirements for the degree of

Doctor of Philosophy

in

Communication and Media Studies

Eastern Mediterranean University

September 2017

Gazimağusa, North Cyprus 
Approval of the Institute of Graduate Studies and Research

Assoc. Prof. Dr. Ali Hakan Ulusoy Acting Director

I certify that this thesis satisfies the requirements as a thesis for the degree of Doctor of philosophy in Communication and Media Studies.

Assoc. Prof. Dr. Agah Gümüş

Dean, Faculty of Communication and Media Studies

We certify that we have read this thesis and that in our opinion it is fully adequate in scope and quality as a thesis for the degree of Doctor of philosophy in Communication and Media Studies.

Prof. Dr. Süleyman İrvan Supervisor

Examining Committee

1. Prof. Dr. Süleyman İrvan

2. Prof. Dr. Ömer Özer

3. Prof. Dr. Serdar Öztürk

4. Assoc. Prof. Dr. Nurten Kara

5. Asst. Prof. Dr. Pembe Behçetoğulları 


\begin{abstract}
This empirical study aims to investigate the image of beauty standards constructed by the Turkish teen magazines and its relation with the beauty understanding of Turkish Cypriot teenagers. Other issues investigated are the consumption behavior of teenagers who read teen magazines and the body satisfaction of teenage girls.
\end{abstract}

This study employs three different methodologies. Firstly, a content analysis covering 12 issues each spanning 4 years is performed on two popular Turkish teen magazines, Hey Girl and Cosmo Girl, read by Turkish Cypriot girls. Then a questionnaire is applied to 156 girls, for investigating how teen magazines affect the beauty understanding, various behaviors and value judgments of teenage girls. The questionnaire includes a body satisfaction inventory section. Finally, a focus group study is performed with six different groups of girls aged 12-17 years discussing with them their beauty standards, body satisfaction, consumption habits and magazine reading habits. The findings indicate that the ideal beauty concept of Turkish Cypriot girls is very similar to the ideal Western beauty and teen magazines contribute to this as well as other sources of media. Teen magazines are also affecting the consumption behavior of girls. Girls read magazines to get rid of their worries and to get information on fashion and beauty trends and products. Girls show signs of body dissatisfaction especially with regards to their weight.

Keywords: Teen magazines, Body Satisfaction, Beauty Standards, Consumption Habits, Feminism, Cultivation Theory. 


\section{$\ddot{O Z Z}$}

Bu nicel çalışma, Türk genç kız dergilerinin oluşturduğu güzellik standartlarını ve bunun Kıbrıslı Türk genç kızların güzellik anlayışları ile ilişkisini incelemektedir. Bunun yanında, genç kız dergilerini okuyan genç kızların tüketim alışkanlıkları ile genç kızların bedenlerinden ne ölçüde memnun oldukları da incelenmiştir.

Çalışmada üç ayrı araştırma yöntemi kullanılmıştır. İlk olarak, Türkçe olarak yayımlanan Hey Girl ve Cosmo Girl genç kız dergileri üzerinde 4 yıllık süreyi kapsayan 12'şer sayı için içerik analizi yapılmıştır. İkinci olarak 156 genç kıza bir anket uygulanarak, genç kız dergilerinin kızların güzellik anlayışlarını ve değer yargılarını ne ölçüde etkilediği belirlenmeye çalışılmıştır. Uygulanan anket içinde beden memnuniyeti envanteri de yer almıştır. Son olarak 12-17 yaş arasındaki genç kızlarla 6 gruptan oluşan odak grup çalışması gerçekleştirilerek dergileri okuma alışkanlıkları, güzellik standartları, beden memnuniyetleri ve tüketim alışkanlıkları detaylı olarak tartışılmıștır. Çalıșmanın bulguları, Kıbrıslı Türk genç kızların ideal güzellik anlayışının batılı güzellik anlayışına çok yakın olduğunu ve buna diğer medya kaynakları ile birlikte genç kız dergilerinin de etki yaptığını göstermektedir. Dergiler ayrıca genç kızların tüketim davranışlarını da etkilemektedir. Genç kızlar dergileri dertlerini unutmak ve moda ve güzellik konularında yeni eğilimler ve ürünler hakkında bilgi almak için okumaktadırlar. Genç kızlar özellikle kiloları konusunda memnuniyetsizdirler.

Anahtar Kelimeler: Genç kız dergileri, Beden memnuniyeti, Güzellik standartları, Tüketim alışkanlıkları, Feminizm, Yetiştirme Tezi. 


\section{DEDICATION}

To my Family... 


\section{ACKNOWLEDGEMENT}

I would like to thank my thesis supervisor Prof. Dr. Süleyman İrvan and for his continuous support and guidance in the preparation of this study. Without his invaluable supervision, all my efforts could have been short-sighted.

Special thanks go to Assoc. Prof. Dr. Nurten Kara, for the long hours she dedicated to me and for her endless patience. Her contribution as a member of my Ph. D. Followup Committee, definitely led to the improvement of the quality of this work.

I would also like to thank Assistant Prof. Dr. Pembe Pehçetoğulları, who was also a member of my Ph.D. Follow-up Comittee, for her constructive criticisms and interesting suggestions.

Special thanks also go to my dissertation jury members Prof. Dr. Ömer Özer and Prof. Dr. Serdar Öztürk for their important contributions and suggestions which improved the final version of this thesis and which will help me in my future studies.

I would like to thank Ms. Canay Ataöz and other library staff members for their great efforts in helping me to find documents and papers difficult to reach.

I would like to thank my mother and father, my husband and my children who supported me all throuought my studies. Without their understanding, love and motivation, this study would never have been finished. 
Thanks also to my colleagues for their support, especially to my dear friend Asst. Prof.

Dr. Nazan Doğruer for her help in statistical analysis.

Special thanks go to all Turkish Cypriot teenager girls who willingly took part in this study, and to the administrations and teachers of schools, especially to Mrs. Emine Unku, who permitted the conduction of the questionnaire and focus group studies. 


\section{TABLE OF CONTENTS}

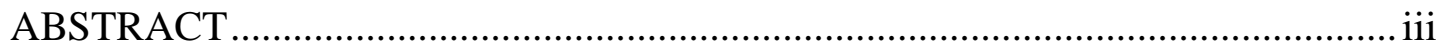

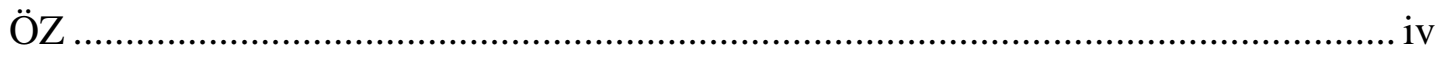

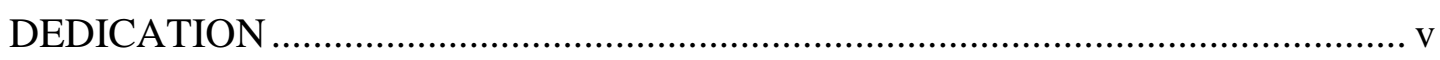

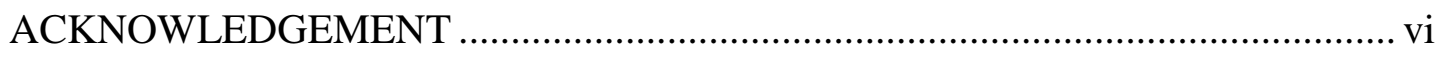

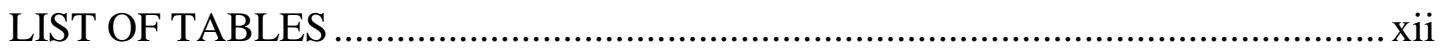

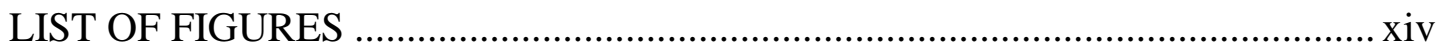

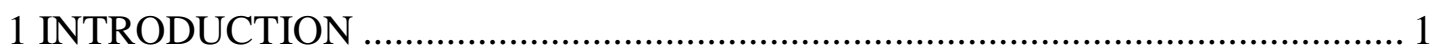

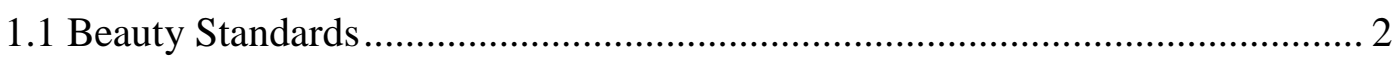

1.2 Representation of Women in Media.............................................................. 4

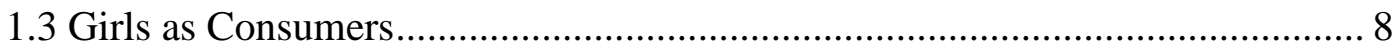

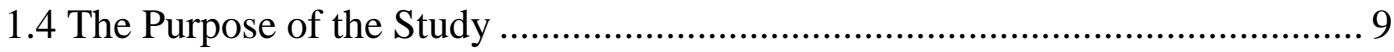

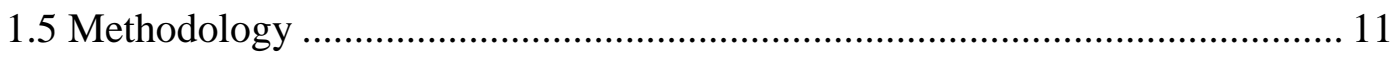

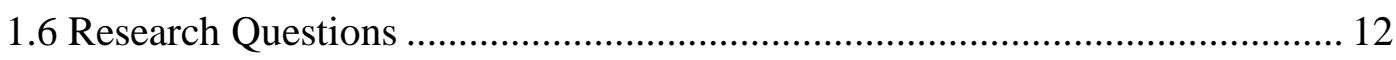

1.7 Limitations and the Significance of the Study ........................................... 12

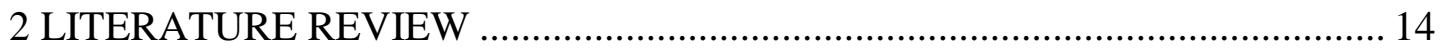

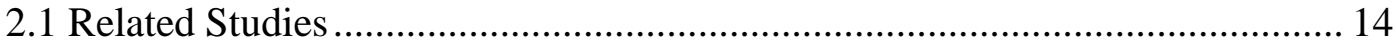

2.1.1 Studies on Teen Magazines ............................................................... 14

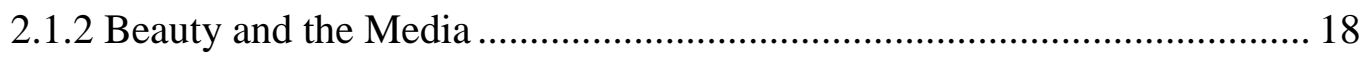

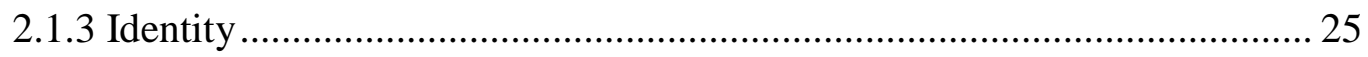

2.1.4 Body Image / Body Satisfaction ........................................................... 31

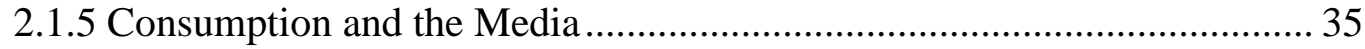

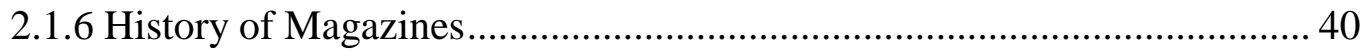




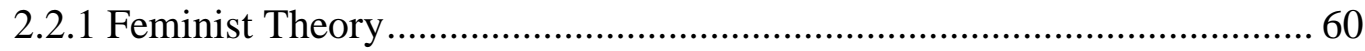

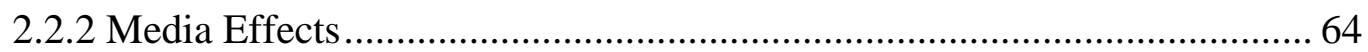

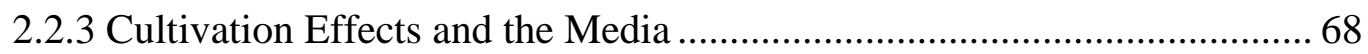

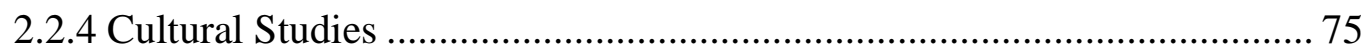

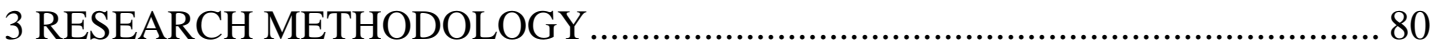

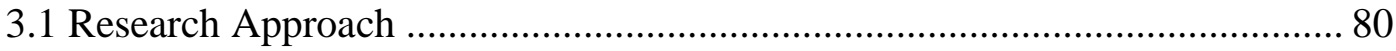

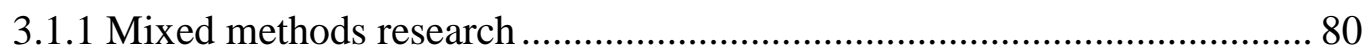

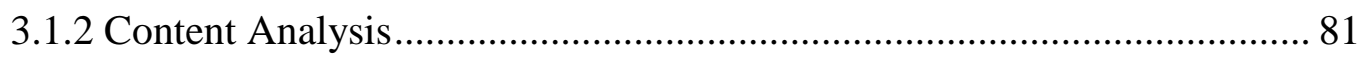

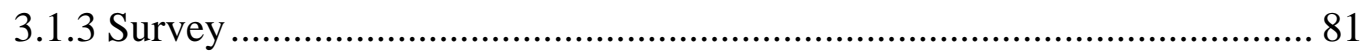

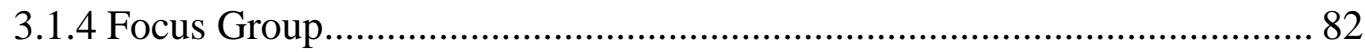

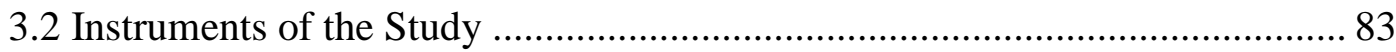

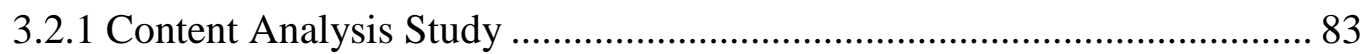

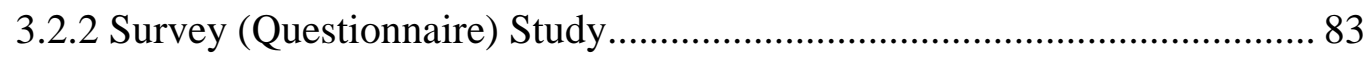

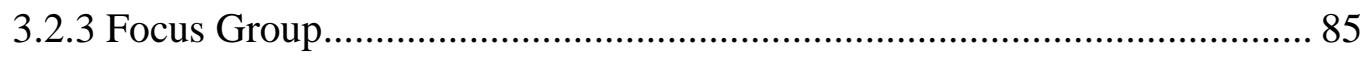

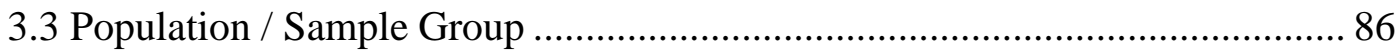

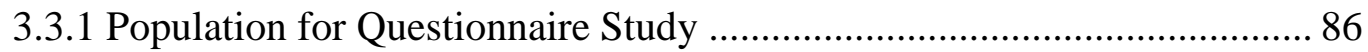

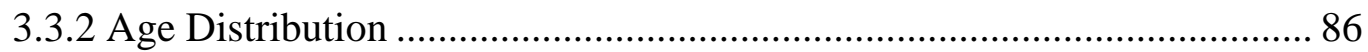

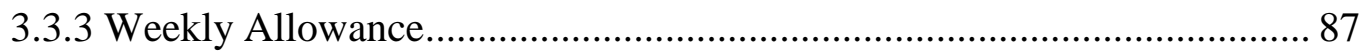

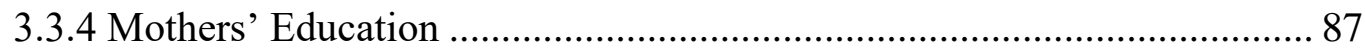

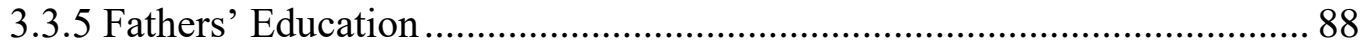

3.3.2 Sample Group for Content Analysis Study ......................................... 88

3.3.3 Population for Focus Group Study ..................................................... 90

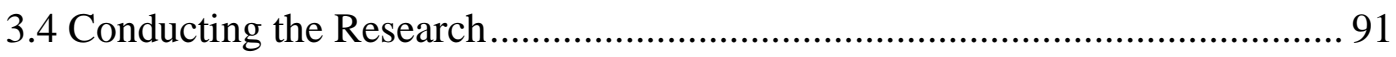

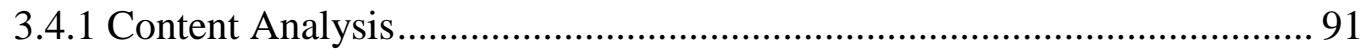




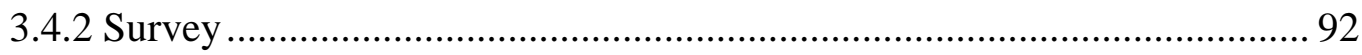

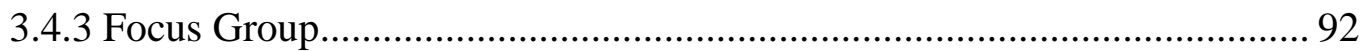

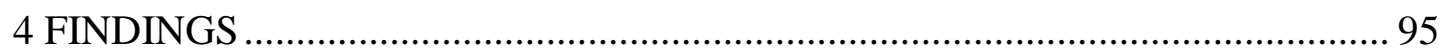

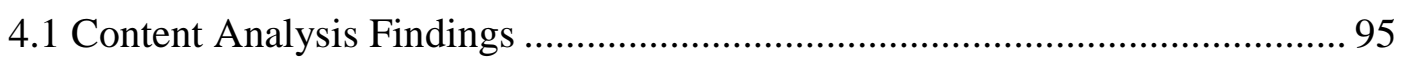

4.1.1 Coverage of Hey Girl and Cosmo Girl Magazines.................................. 95

4.1.2 Content Analysis of Teen Magazine Covers ........................................ 105

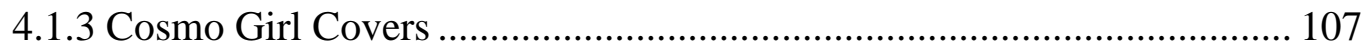

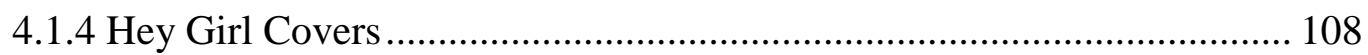

4.1.5 Comparison of Cosmo Girl and Hey Girl covers ................................. 109

4.1.6 Comparison of Cosmo Girl-Turkey and Seventeen-USA Magazines ..... 110

4.1.7 General Remarks on Magazine Contents ............................................ 114

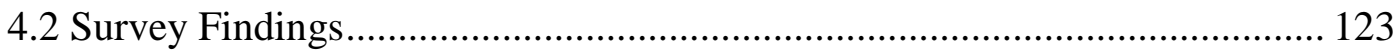

4.2.1 Shopping from Supermarkets for the Family ...................................... 123

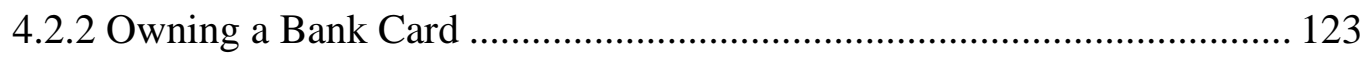

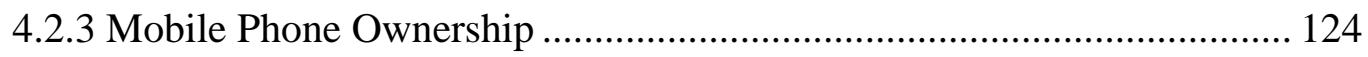

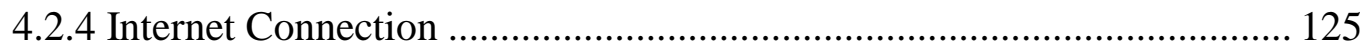

4.2.5 Satellite Receiver and Satellite Music Channels Watched ..................... 126

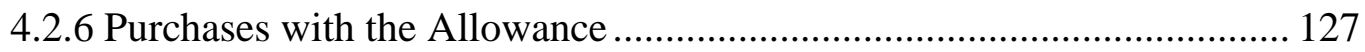

4.2.7 Purchasing Plans for the Near Future ................................................ 128

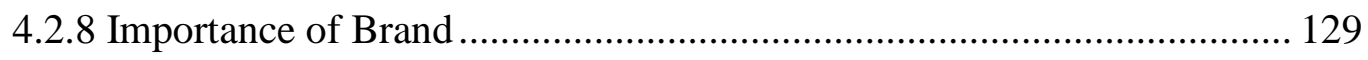

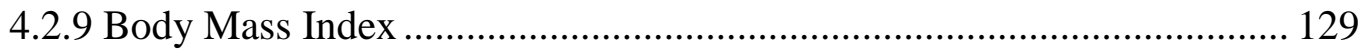

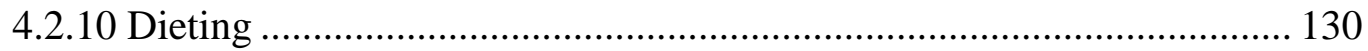

4.2.11 The Most Beautiful Eye and Hair Colors ............................................ 131

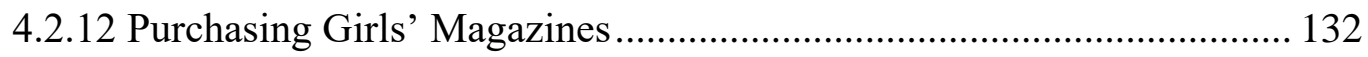

4.2.13 Reasons for not Purchasing Girls' Magazines .................................... 133 
4.2.14 Girls’ Magazines Purchased

4.2.15 Informing the Family about Purchasing Girls' Magazines................... 134

4.2.16 Favorite Place for Reading Girls’ Magazines....................................... 135

4.2.17 Most Favorite Girls’ Magazine .............................................................. 135

4.2.18 Magazine Reading in the Last Week ................................................. 136

4.2.19 Factors Affecting the Purchase of Girls' Magazines ............................ 136

4.2.20 Factors Affecting Shopping of Girls ................................................ 137

4.2.21 Sections Liked Most in Girls' Magazines .......................................... 137

4.2.22 Type of clothes that appear most in girls' closets............................... 138

4.2.23 Girls' Magazines and Daily Lives of Girls......................................... 139

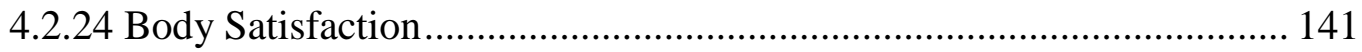

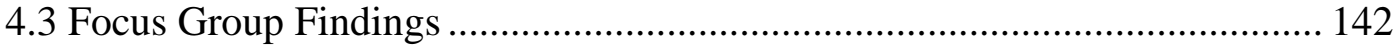

4.3.1 Reading and Use of Teen Magazines ................................................... 142

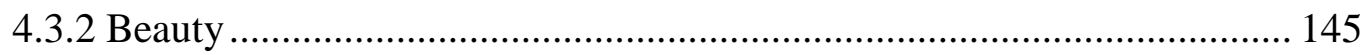

4.3.3 Consumption: Fashion, Beauty, and Brand Products ........................... 151

4.3.4 Teen Magazines as the Secret Garden of Adolescent Girls.................... 156

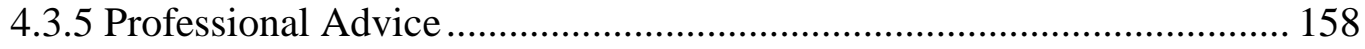

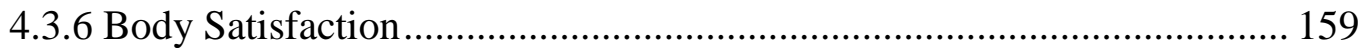

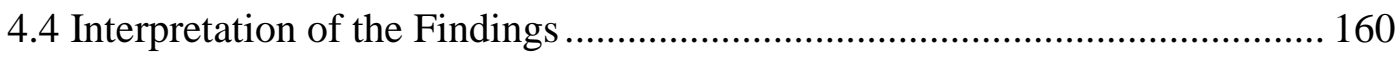

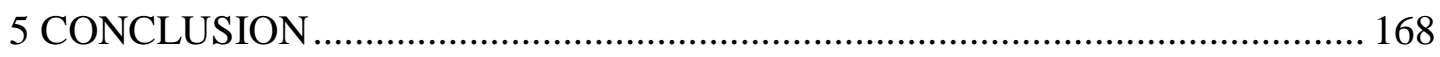

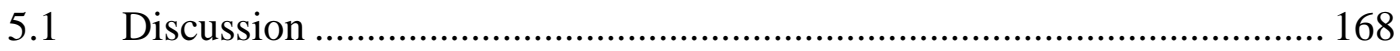

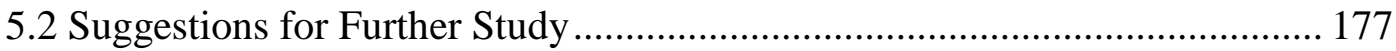

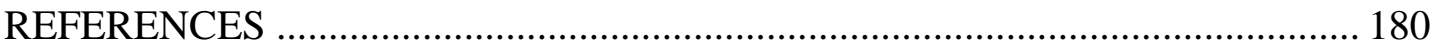

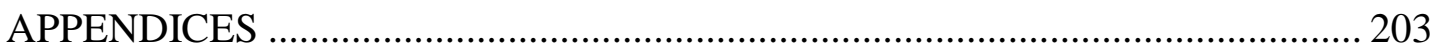




\section{LIST OF TABLES}

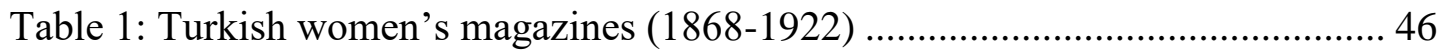

Table 2: Turkish teen magazines (Until 2007)..................................................... 59

Table 3: Age distribution of questionnaire respondents ..................................... 86

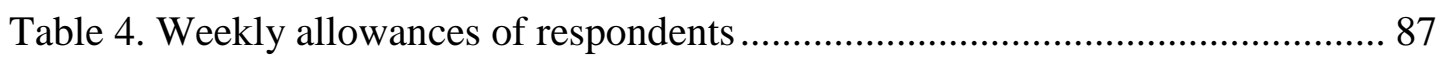

Table 5. Education level distribution of mothers ................................................ 87

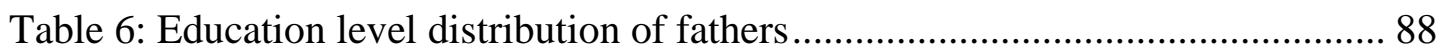

Table 7: Overall category averages of the content analysis study ........................... 97

Table 8: Distribution of advertisements among product categories....................... 101

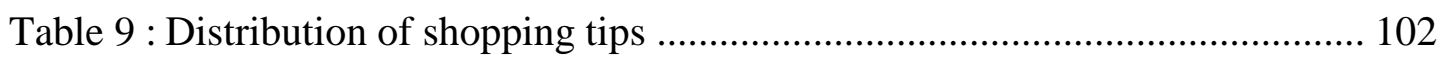

Table 10 : Distribution of celebrities among celebrity categories .......................... 103

Table 11 : Content analysis results of Cosmo Girl covers …................................. 106

Table 12: Content analysis results of Hey Girl covers........................................ 107

Table 13 : Shopping from supermarkets for the family ....................................... 123

Table 14 : Ownership of personal bank card..................................................... 124

Table 15 : Do you have a personal mobile phone? ............................................... 124

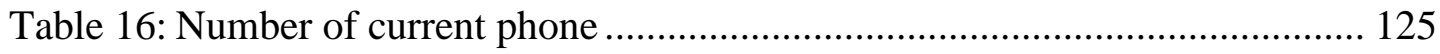

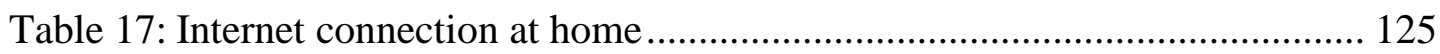

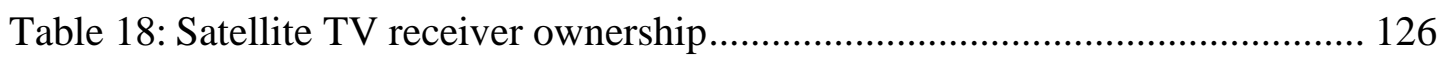

Table 19: Satellite TV music theme channels most watched............................... 127

Table 20 : Item purchased most with allowance ................................................ 127

Table 21 : Item To Be Purchased In The Near Future .......................................... 128

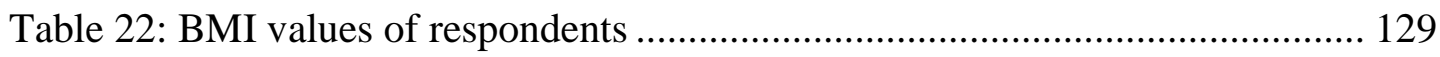




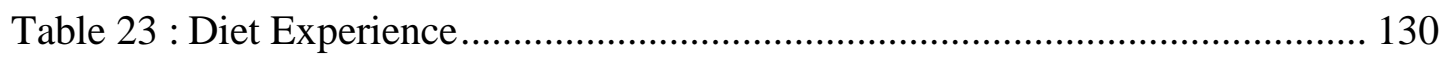

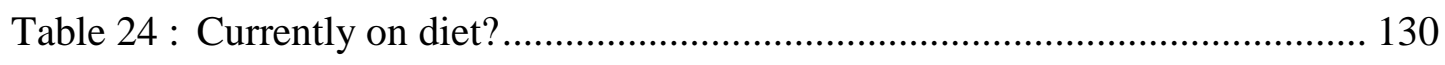

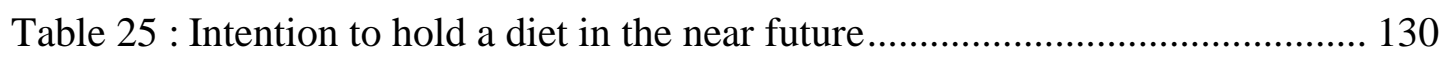

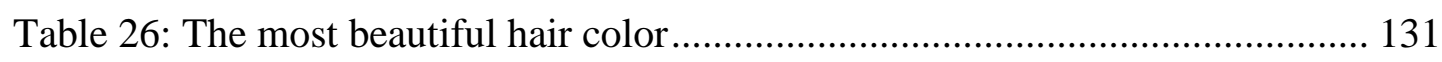

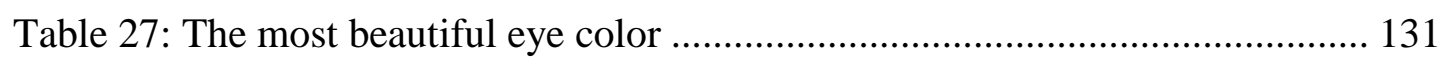

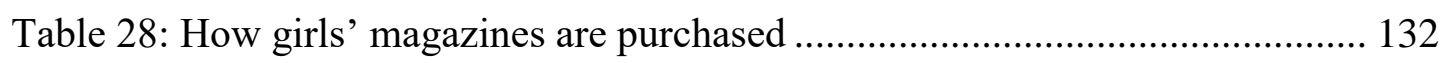

Table 29: The reasons for not purchasing girls' magazines................................. 133

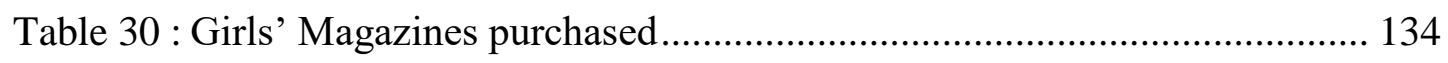

Table 31 : Informing the Family about Purchasing Girls' Magazines ..................... 134

Table 32 : Favorite place for reading girls' magazines ....................................... 135

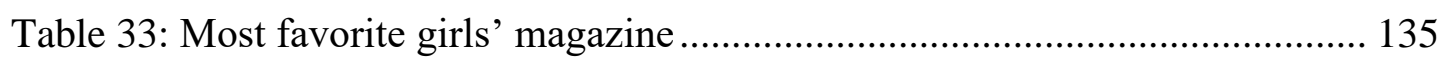

Table 34 : Have you read a magazine in the last week? ...................................... 136

Table 35: Factors affecting the purchase of girls' magazines ................................ 136

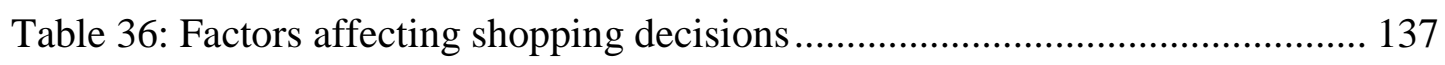

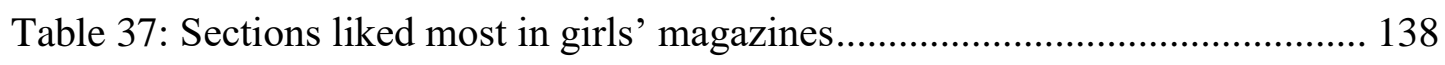

Table 38 : Type of clothes that appear most in girls' closets................................ 139

Table 39: Magazines entertain me and help me forget my worries ........................ 140

Table 40 : Magazines help me correctly direct my mother or sisters ..................... 140

Table 41 : The clothes I wear fit me perfectly as much as celebrities .................... 141 


\section{LIST OF FIGURES}

Figure 1: The Female Spectator and Godey's Ladies Book .................................... 42

Figure 2: Cosmopolitan Magazine, May 1896, Sample Cover................................ 43

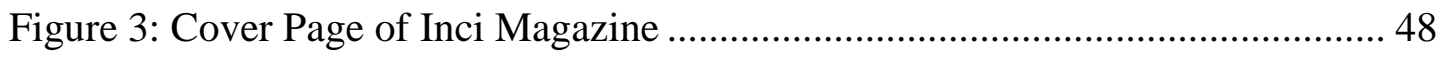

Figure 4: Sample Covers of Yelpaze, Sevgilim and Hafta Magazines..................... 51

Figure 5: Sample Cover of an Early Edition of Seventeen Magazine (1944)............ 55

Figure 6: Overall Percentage of Categories in Magazines....................................... 99

Figure 7: Overall Percentage of Advertisements with Respect to Categories ......... 102

Figure 8: Overall Distribution of Shopping Tips ............................................... 103

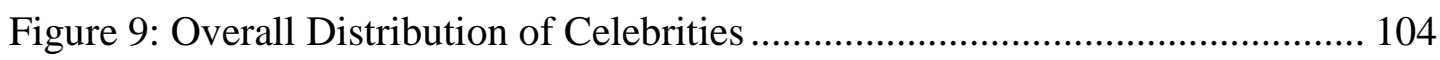




\section{Chapter 1}

\section{INTRODUCTION}

This empirical study aims to investigate the ideal beauty image constructed by the Turkish teen magazines and whether there is any common beauty standard among Turkish Cypriot teenagers. Other issues taken into consideration are the consumption behavior and the body satisfaction of teenagers who read teen magazines.

The motivation for this study can be explained as follows: I studied child development and education and I am the mother of a girl who was a teenager when I started my $\mathrm{PhD}$ studies. One day, I saw teen magazines on her desk, and I noticed that the cover girls were almost all blonde and thin. Then, I noticed that my daughter and her friends were questioning their looks compared to the cover models. I realized that these teen magazines, among other factors, may be influencing young girls with regards to their beauty ideals and I decided to conduct this study.

Most of the female teenagers in the developed world read popular teen magazines, which is also true for teenagers living in Turkey and North Cyprus. Therefore, teen magazines may play an important role in shaping identities, promoting consumption and influencing teenager behavior.

This study is performed with a mixed-method approach and it employs three different research methodologies. Firstly, a content analysis is performed on two popular 
Turkish teen magazines with highest circulation: Hey Girl and Cosmo Girl, read by Turkish Cypriot girls. The content analysis study has taken into consideration 12 randomly selected issues of each of the mentioned magazines published in 2007-2010. On the other hand, using the survey approach, a questionnaire is applied to 156 girls, to understand their magazine reading experiences and to investigate how teen magazines affect the beauty understanding, and consumption habits of teenage girls. The questionnaire includes a body satisfaction inventory section. Finally, a focus group study is performed with six different groups of girls aged 12-17 years, discussing with them their beauty standards, body satisfaction, consumption habits and magazine reading habits.

The study includes a literature review to discuss similar studies on teen and women's magazines, beauty standards and body satisfaction. One part of the literature review on beauty standards, the representation of women in media and girls as consumers is in this Introduction chapter, and the other part is in section 2.1.

A study on teen magazines should include an analysis from consumption point of view. Results discussed in our content analysis of popular teen magazines include the amount of coverage given to advertisements, shopping tips and beauty products. It is shown that the total price of all goods and products advertised sums up to a very high value.

\subsection{Beauty Standards}

When you ask the following question to teenagers: "how should a beautiful girl look like?" the answers you receive reflect the beauty standards valid among teenagers in that society. If you ask the same question in another society, you may expect to get different answers. However, is it really the case? If not, and if the answers we get in 
different societies do not differ much, then can we talk about a 'global beauty concept'?

Where do these beauty standards come from? How is it possible that most of the teenagers give exactly the same answers in defining beauty? It seems that the beauty concept is established as a part of our culture. So, how is this concept cultivated? To understand this, one has to analyze the development of the beauty concept in history.

Since ancient times, feminine beauty have carried great importance and women have tried to meet beauty ideals of their society. The definition of beautiful woman changes: it changes in time within the same society; it changes from one culture to the other at the same moment in history (Davis, 2000; Felski, 2006). In addition, different societies have had different local beauty standards. Even nowadays, different societies may have different standards for beauty. For example, although in general being thinner is believed to be more desirable in many regions of the world, Azawagh Arabs of Niger believe that fat women are more beautiful (Felski, 2006, p. 278). Sculptures from early Greek civilization display women with larger body. Considering the Ottoman Empire, women with larger hips and medium weight were considered to be beautiful. However this changed in time, and in the modern Turkish society, beauty ideals demand women to be slim. Similarly, it has been shown that ideal waist-to-hip ratio of women has changed over time in western societies from $500 \mathrm{BC}$ to today (Bovet \& Raymond, 2015).

Women sometimes choose painful methods to get closer to the beauty standards set by their cultural environment. For example in ancient China, women with little feet were 
considered to be beautiful, so there was a foot-binding practice among women to keep their feet small. Also, in some African tribes, women put metal circles on their necks one after the other because women with longer necks are considered beautiful.

In early times, travel to other countries was not common, and transportation to long distances was difficult. Therefore, societies were not affected from each other's beauty standards, as there was no direct interaction between cultures. After the Industrial Revolution, the invention of the steam engine made travelling to long distances by train or ships possible. With the beginning of the 20th century, traveling became more convenient as better railroads and highways were constructed. International travel became easier and much faster with the invention of the airplane. With all these advances, the level of cultural and economic interaction between people, cities and nations grew higher and higher. Thus, with the western culture becoming more dominant, non-western societies began to be influenced by western beauty standards.

However, it should be added that beauty does not only have a cultural perspective. It also has, biological, anthropological and aesthetic dimensions, which are not covered in this study.

\subsection{Representation of Women in Media}

In the second half of the twentieth century, the "globalization" process, which started aiming to create a single "world market" from an economic point of view, has resulted in a single world "with increased, even unavoidable contact" (Featherstone, 1996, p. 47). New media technologies such as radio, telephone and television "eliminated time and space factors in human associations, creating involvement in depth" (McLuhan, 2006, p.108). Media also became globalized, and television broadcasting was widely 
spread over the whole world in the second part of the 20th century. In his book "Understanding Media", McLuhan pointed out how electronic communication was changing the way we perceive ourselves and our world. "Technologies such as telephone, radio, and television were shrinking distances, accelerating communication, and giving us a world far different from that which previous generations had experienced." (p. 109). McLuhan used the phrase "global village" to highlight his observation that "an electronic nervous system (the media) was rapidly integrating the planet -- events in one part of the world could be experienced from other parts in realtime, which is what human experience was like when we lived in small villages." (p. 109).

Local newspapers and magazines started giving more and more coverage to international events, news and celebrities like movie, television or music stars. Accordingly, a global beauty standard, predominantly white, blonde and thin, started being promoted in women and girls' magazines, TV series, magazine programs, and various other media types. Consequently, many societies such as China, Japan, and other Asian countries, and even African-Americans "revised" their local beauty standards and adopted Western standards of beauty (Bordo, 1993; Darling-Wolf, 2004; Gordon, 2004; Gane, 2007; Xu, 2007; Crawford, 2008). Consequently, many women and teenagers, especially those living in countries where the white Anglo-Saxon culture was not historically dominant, are now not happy with their looks.

Mass media refers to TV sitcoms, music shows and dramas, movies, books, newspapers, magazines, music DVD's and the like, created and disseminated for wide consumption. In recent years, some researchers have studied how women are 
represented in mass media. Marian Meyers (1999), who edited a book on mediated women, indicates that the first book which discusses the representation of women in mediated popular culture was written in 1978 by Tuchman, Daniels and Benet titled "Hearth and Home: Images of Women in the Mass Media". Meyers states that compared to the end of 1970's there are now more magazines on the market targeting specialized consumer groups like young audiences (teen magazines), young women, working mothers, and brides.

Meyers concentrates on finding out how media texts promote particular understandings of women's lives and roles, and indicates that media images define and reinforce white, middle-class standards of feminine beauty and desirability. She mentions women that appear in media content "tend to be young and pretty, defined in relation to their husband, father, son, boss and other men, and they are portrayed as passive, indecisive, submissive and dependent" (p. 10). Similar remarks are made by Coleman (2008) indicating "a homogenization of western cultural images of female bodies as young, white thin, attractive, healthy, heterosexual and middle class" ( $\mathrm{p}$. 164).

Another quantitative study on the representation of women in media is Nancy Signorielli's (1997) content analysis across six media, which are heavily used by teenage girls. She shows that media represents both positive and negative images of women. This gives conflicting messages to adolescent girls about their own potential. Many of the female characters she studied in her study were strong, independent, intelligent and honest girls, but physical appearance and relationships were of primary concern to them. On the other hand, her study showed that for male characters, jobs 
and careers were much more important. The major message of media is that girls/women can be strong, independent, and intelligent as long as they remain at home and within their relationships, while also maintaining traditional standards for female beauty.

It has also been reported that adolescent girls get pleasure from reading teen magazines, which, in addition to other types of media, affect the adolescent girls by communicating messages about ideal beauty and stereotypical gender roles (Radway, 1991; Ballentine \& Ogle, 2005; Nam, Lee \& Hwang, 2011). Studies have also been conducted on the effect of teen magazines on adolescent girls' beauty perception and consumption habits in general (McRobbie, 1993; Gonick, 1997; Duke \& Kreshel, 1998; Gane, 2007; Kim et al., 2011), and in different countries around the world (Silvestre, 2009; Chen \& Jackson, 2012; Nam, et al., 2011). Most of the results of these studies suggest that a western beauty standard that characterizes women as thin, blueeyed, blonde, and with an upturned nose, is promoted globally in women's and adolescent girls' magazines. Being repeatedly subjected to these messages about beauty may cause a cultivation effect on women (Gerbner, 1999). Similarly, feminists claim that society continually forces girls and women to conform to the image of feminine beauty (Wolf, 1991).

The media and advertising industry frequently use idealized images of femininity to further increase the desire to attain ideal beauty. Wolf states that "the modern arsenal of the (beauty) myth is a dissemination of millions of images of the current ideal" (Wolf, 1991, p. 16). The continuous promotion of this standard makes adolescents less happy with their looks, and results in body dissatisfaction (Ballentine \& Ogle, 2005; 
Tiggemann, 2003; Knauss, Paxton, \& Alsaker, 2007; Chen \& Jackson, 2012). Voelker, Reel, and Greenleaf (2015) indicated that adolescence is a critical period in body image development and that media influence body image perception. Likewise, Bucchianeri, Arikian, Hannan, Eisenberg, and Neumark-Sztainer (2013) showed that body dissatisfaction increased during middle and high school years. In addition, Silvestre (2009) found out that the "thin body ideal" promoted in Western society was an important factor in female adolescent body dissatisfaction in Portugal. Sauer and Robles-Piña's (2003) findings show that adolescent girls perceive themselves as overweight even when they are not, and some attempt to become thinner by adopting unhealthy dietary habits.

\subsection{Girls as Consumers}

It is reported that research on consumer theory has not given enough coverage to fashion and beauty expenditures by women, teenager girls and tweens (children with ages between 7 and 12). Youth are covered in some recent cultural studies, but mainly from a subculture point of view. When it comes to children, not much work is reported. Instead, children's roles must be acknowledged and investigated as an important part of consumer culture (Cook, 2008).

McRobbie (1993) stated that adolescent girls are being introduced to and educated into the sphere of feminine consumption through magazines. Other researchers have shown that girls become major consumers of cosmetic products in an attempt to attain an unreachable beauty standard (Martin \& Peters, 2005; Opree, Buijzen, van Reijmersdal, \& Valkenburg, 2014). Ballentine and Ogle (2005) reported that adolescents place higher importance on appearance than adults, and the popular media promote the use of consumer products for achieving the ideal body shape. In a study on teen magazines, 
Evans, Rutberg, Sather, and Turner (1991) showed that advertisements are mostly for beauty products and fashion. The rest of the relationships of girls' consumption habits and teen magazines are discussed in section 2.1.5.

\subsection{The Purpose of the Study}

From the discussion above, it is evident that more research is needed on children, tweens and teenagers, concentrating on their lives, understandings, culture, and consumption habits and the link between teen magazines and the consumer society. This study is conducted taking this lack of research mentioned into consideration. It is mainly an empirical study, it concentrates on Turkish Cypriot girls of the 12-17 years old age group, and it aims to investigate the coverage of ideal beauty concept in girls' magazines, the girls' understanding of beauty and fashion, and their body satisfaction.

Another aim is to investigate the consumption behavior of Turkish Cypriot teenagers, and whether reading magazines influences this behavior.

The research arguments of this study are theoretically based on feminist arguments on physical appearance and body images of women and teenagers, and the impact of teen magazines on the beauty understanding of young girls.

Methodologies selected for the study are content analysis, survey analysis and focus group analysis. Therefore this is a mixed-method research study.

The following issues are considered in conducting the study: What kind of an ideal beauty image is promoted by teen magazines? Is there a common "ideal teenager" image among Turkish Cypriot girls? Do teen magazines play a role in developing an 
image of "ideal teenager"? Do teenager girls take those magazines as a reference in defining the "ideal teenager"? Are teenagers happy with their current appearance? Do teen magazines play a role in driving teenager girls to become heavy consumers through the images they present? The research questions stated in Chapter 3 are shaped around those issues.

This study makes use of the Cultivation Theory as it discusses whether a standard beauty image is cultivated in Turkish Cypriot girls' minds through repeated western thin-white-blonde ideal beauty messages in media. Similarly, I try to find out the impact of frequent advertisements and shopping tips on beauty and fashion products in teen magazines on girls' consumption habits.

It was indicated above that my stance is a feminist one. The main goal of the feminists is "to achieve a state of social equality between the sexes through the validation of diversity, proliferation of free choice, and deconstruction of gender stereotypes" (Tornblom, 2006, p. 1). In this context, drawing attention to the repeated and dominant appearance of traditional sex role stereotypes in magazines is an important task for a feminist study. Also, from the feminist perspective, "in order to illustrate the influence the media has on the lives of women, it is necessary to explore the types of messages put forth by the media" (p. 1), and the impact of such messages on the self-perceptions of women. Accordingly, in this study, a feminist approach is also used in discussing the reasons of body dissatisfaction among adolescent girls.

Feminist researchers state that the society pressures adolescent girls to accept the image of "feminine beauty" (Wolf, 1991; Purdy, 2005) and forces them to use beauty 
products to achieve similar looks, which is actually impossible to attain. This is an important motive resulting in teenagers becoming consumers of expensive brand clothes and beauty products.

The results of this study are expected to contribute to the discussions on if and to what extent girls' magazines create a concept of ideal beauty, cause body dissatisfaction among teenage girls and direct them to spend a lot of money on fashion and beauty products to get closer to the ideal beauty.

\subsection{Methodology}

This study is performed on 12-17 year-old Turkish Cypriot teenager girls. The study is an empirical one with a mixed-methods approach. It is composed of a questionnaire study performed on 156 teenager girls, a content analysis on two popular teen magazines (Hey Girl and Cosmo Girl) published in Turkey, and a focus group study.

The content analysis method is applied to teen magazines to find out the coverage of beauty and fashion topics, and consumerist messages related with the "ideal teenager" concept. Hey Girl and Cosmo Girl magazines are selected for the content analysis study considering the sales of teen magazines in Northern Cyprus for the period 20022010 .

To our knowledge, no researcher has reported the impact of teen magazines on Turkish Cypriot adolescent girls. To fill this gap and to investigate the ways in which adolescent girls in North Cyprus interact with magazines, we used focus group methodology to understand the effect of the messages in teen magazines from a reader's perspective. 


\subsection{Research Questions}

The following research questions are addressed in this research:

1. To what extent do teen magazines influence Turkish Cypriot adolescent girls' perception of ideal beauty?

2. To what extent do teen magazines trigger Turkish Cypriot adolescent girls' consumption behavior in regard to cosmetics and fashion brands?

3. For what reasons do Turkish Cypriot adolescent girls read teen magazines?

4. Are Turkish Cypriot teenagers happy with their current appearance?

\subsection{Limitations and the Significance of the Study}

This study is limited with one type of media: teen magazines. Hey Girl and Cosmo

Girl teen magazines were used in this study as they are the ones which have the highest circulation. Other media types, such as television programs, movies, and newspapers that play roles in the construction of the ideal beauty concept are not considered. Also the study does not consider boys and their magazines as there is no boys magazine published in Turkey for the same age group.

The domain of this study is limited with the Northern Cyprus society. Only teenage girls aged 12-17, living in Northern Cyprus are considered.

The significance of this study can be summarized as follows:

- to our knowledge, it is the first audience side study performed on girls' magazines published in Turkish.

- it covers a gap in social research on teenage girls and teen magazines (Colins, 2011). 
- to our knowledge, it is the first mixed methods study performed on girls' magazines.

The rest of this thesis is organized as follows: In Chapter 2, a literature review is given on related studies and theories. In Chapter 3, the research methodology is explained. In Chapter 4, the findings of the study are stated. The thesis is concluded with the Conclusion chapter which is followed by the Appendix. 


\section{Chapter 2}

\section{LITERATURE REVIEW}

In this chapter, a literature review will be presented discussing studies on teen magazines, beauty and media, identity, body satisfaction, and consumption and media. This will be followed by the history of women's and teen magazines in the world an in Turkey. The chapter will be concluded with the discussion of theories related with this research.

\subsection{Related Studies}

\subsubsection{Studies on Teen Magazines}

The first reported content analysis of teen magazines was performed by McRobbie in 1978 on the British weekly Jackie magazine. Jackie magazine was chosen as it was the best-selling teen magazine for girls in UK for over 10 years at the time of study. McRobbie (1991) reported that Jackie was the "bearer of an ideology, dealing with the construction of teenage femininity" (pp. 81-82), which was basically a conventional look into femininity, "with no interest in improvements of the women's position in society" (pp. 190-191).

Peirce (1993) has carried out a content analysis of fiction articles in Seventeen and Teen magazines. Peirce analyzed 104 fiction stories published in those magazines for the 5 year period 1987-1991. Dependence and occupational status were chosen for analysis because of their prominence in women's magazine research, and because of 
their importance in gender role socialization. She reports that Seventeen and Teen give the following messages to girls: "male-female relationships are more important than just about anything", and that "there really are male and female professions" (p. 65).

A content analysis study (Evans et al., 1991) reported findings similar to that of Peirce (1993). In this study, ten issues each of Sassy, Seventeen and Young Miss teen magazines published in 1988 were analyzed. The study covered articles, columns, fiction and advertisements. One finding is that fashion topics dominated the editorial pages, followed by beauty care as the second widely covered topic. Advertisements were mostly for beauty products and for fashion clothing.

Marnina Gonick (1997) lists some of her findings from her focus group studies with $6^{\text {th }}$ and $7^{\text {th }}$ grade girls of Asian backgrounds in a Canadian public school (p. 69). When Gonick asked teenager girls what kind of teen magazine issues they wanted to work on, girls responded by mentioning issues like fashion, make-up tips, entertainment, and surveys (Gonick, 2003, pp. 38-39). Gonick states that when she tried to convince the girls with whom she was conducting a focus group study to look at an American noncommercial magazine, New Moon, published as an alternative to teen magazines, they rejected it in favor of the regular teen magazines they read (Gonick, 1997, p. 69).

Duke and Kreshel (1998) conducted in-depth private conversations (interviews) with ten girls aged 12-13, who were regularly reading teen magazines Seventeen, Sassy, YM or Teen. They describe how girls interpret the mediated images of femininity targeting them in teen magazines. They claim teen magazines give the message that by trying hard enough anyone can reach ideal beauty. 
Willemsen (1998) performed a content analysis on six issues each of one girls' magazine and one boys' magazine published in the Netherlands. She studied the language use in introductory parts of articles on sex and relationships. Willemsen indicates that the introduction of a general interest magazine called "Webber" for boys in the Netherlands in 1994, created a good chance for performing a comparative study on girls' and boy's magazines. She chose "Yes" as the girls' magazine to study. One limitation of her research is that she used only the editorial pages for her study. Willemsen categorizes fashion, beauty, love and relationship and romantic fiction topics as stereotypically feminine. She then explains that hobbies should also be considered as a gender-specific topic since the two magazines cover completely different hobbies.

In 1999, Kehily, analyzed British teen magazines "More!" and "Sugar”, which discuss sexuality in articles and advice columns. Garner et al. (1998), examined the April and October 1974, 1984 and 1994 issues of YM, Teen, Seventeen, Glamour and Mademoiselle Magazines, and conducted a content analysis on advice columns and stories, investigating messages about social and cultural norms for sex and sexual relationships.

Sauer and Robles-Pina (2003) analyzed the relationship between the contents of magazines that girls read and their perception of beauty. They discuss the layout and design of teen magazines, and major topics covered and they discuss the main messages - both actual and implied - teenage girls take from these magazines. In determining the teen magazines mostly read, Sauer and Robles-Pina used a self-report survey in their study, and collected data from 20 teenagers. 
Ballentine and Ogle (2005) have studied the "making and unmaking of body problems" in 266 editorial articles published in the "Seventeen" magazine from 1992 to 2003. They state that girls are especially interested in messages about the ideal beauty concept since body is a key factor in defining adolescent They also report that adolescents place higher importance on appearance than adults. In their study they found out that media presents idealized images of the body, and emphasizes the desirability of a body which is well-maintained.

Pardun, L'Engle and Brown (2005) published results of an extensive survey on 12-14 years old early adolescents' consumption of sexual content in six media, including print media. They applied a media-use questionnaire to $32617^{\text {th }}$ and $8^{\text {th }}$ grade students in the United States. One of their findings is that body exposure and description of romantic relationships constitute two thirds of all coded sexual content.

Fuller (2005) conducted a content analysis study on thirteen issues of the Seventeen magazine. She reports that physical appearance is the most dominant theme of the magazine. She also reports that the magazine is giving mixed messages.

Kim K. P.J. et al. (2011) performed a comparative content analysis on more than 1,000 articles published in 2008 and 2009 issues of Seventeen and Teen Vogue magazines. Fashion constitutes the largest percentage of content in general. Teen Vogue is concentrating more on celebrities, while Seventeen concentrates on "teen life issues".

Redcross and Grimes (2014) conducted a survey study on teen magazines published after 1980 's. They explain that the most popular topics in teen magazines are celebrity 
gossip, appearance-oriented articles, dating and socialization and this trend has not changed in the last 35 years. The editors continue with these choices because they think this is what the young girls (consumer) wants. One of the results they list is that they believe "the physical, psychological and social development of adolescent girls will be negatively influenced by repeated exposure to ten magazines" (p. 9).

\subsubsection{Beauty and the Media}

In the Introduction chapter, it was stated that societies and cultures have certain standards which define a beautiful woman. These standards are normally passed from generation to generation without much change in short periods. However, there seems to be some stereotyped beauty definition at a certain period in history, although some archeological findings point to beauty understandings similar to today's ideal western beauty in some early civilizations.

Figurines and idols from early Bronze Age discovered in Anatolia indicate that women have been sculptured with body shapes similar to today's ideal women (with small tits, thin, and even reminding today's fashion models). Almost 2000 years later, the sculptors of the ancient Greek civilizations used body measures of the ideally beautiful women of their times when building sculptures of goddesses. (Darga, 2011).

For ideal beauty understandings of more recent centuries, analyzing a painting of a young woman made in the $18^{\text {th }}$ century, Clark (2008) states that

Many of the paintings of women during the $18^{\text {th }}$ century are similar because there is even a stereotyped beauty that adapts to the values and fashion of each period in history.

She continues by criticizing the objectification of the painting: 
She becomes an object to be seen, just like present-day models do when being photographed to sell products. They are not persons anymore, but objects, because their bodies are fragmented - into a good bosom, a beautiful face, a tiny waist, or an angelic being (p. 340).

On the other hand, in the twentieth century, with the globalization of capitalist life style and media, drastic changes were observed in many societies and cultures such as China, Japan and other Asian cultures (Darling-Wolf, 2004; Xu, 2007; Tu, 2007; Crawford, 2008). These changes have been towards accepting the western white (Caucasian) ideal beauty standards instead of the prominent standards of the local culture over hundreds of years. Many researchers have concluded that mass media and in specific, the print media, have played a role in this transformation process of beauty standards.

Cultural ideals of feminine beauty have fed a new beauty system especially after the industrialization period. This system is based on women's desire for body improvement to meet the beauty standards. Women feel that they must look beautiful both to give a good impression to others at work and to be popular in their social environment (Seid, 1994). Women's need for make-up, dieting, cosmetic surgery and fashionable clothes to look good feeds the cosmetic and fashion industry. Media and advertising industry repeatedly present idealized images of femininity to further increase the desire to attain ideal beauty. Print media has played a role in promoting ideal body standards by frequently publishing photographs of thin, blonde models and celebrities, and articles on the necessity to look good and how to look good. 
Other types of media also promote the ideal beauty. Van Zoonen (1994) states that, "in TV game shows, the assistant to the quiz master is the predictively attractive and scantily dressed blonde" (p. 87). Similarly, in the Turkish version of the wheel-offortune program on Fox TV, host Mehmet Ali Erbil's assistants were mostly slim blondes with filthy dresses. The show has launched a sister program called "50 Blondes" where fifty young women, though not all of them originally blonde, appear with blonde hair, and answer questions for one male competitor. Most of those blondes have actually dyed their hair to tones of yellow.

Teen magazines cannot be excluded from this promotion of ideal beauty concept. A quick review of cover pages of teen magazines will reveal that most of the models/celebrities that appear in magazine covers are thin, blonde, or even if not from the white race, carry some properties (like straight hair and light skin color for blacks) that make them look like a white model (Hooks, 1993). Grogan and Wainwright (1996) state that images in teen magazines present a "very restricted range of models for young women and this should be a matter of concern" (p. 672).

In order to adapt to ideal beauty standards, adolescents who are still trying to construct their identity, use fashion and cosmetic products to create a better image of themselves and these products become a part of their lives. In her study on the teenage girl's magazine Jackie, van Zoonen (1994) states that “...it is taken for granted that the adolescent female body is in need of continuous maintenance and improvement, and Jackie provides step by step manuals to achieve self-improvement" (p.26). She adds that clothing and cosmetics are used by girls "to create a particular and recognizable image for themselves" (p. 26). 
Media and advertising industry frequently use over-idealized images of femininity. For example, Wolf (1991) found out that the average weight of fashion models in 1990 was $23 \%$ below that of ordinary women (p.11). Also, models with ideal women body in mostly sexual looks are used to sell products for men. Van Zoonen (1994) reports that Women's bodies are used as "decorative ingredients in advertisements" prepared for the male audience such as drinks, tools, cars (p. 87).

Jean Kilbourne (2014) discusses in a TEDx session the dangers of widespread use of advertisements in media which present women's body as a sexual object. She adds that in those advertisements emphasis is on "physical perfection", and photo-shop and similar programs are used, creating an impossible ideal look. For models of African or Asian origin, the ones that look closest to the ideal white beauty are selected. She states that "adolescent girls exposed to sexualized images are more prone to eating disorders, depression and low self-esteem".

Some other researchers who have studied the relationship between beauty standards and media messages are indicated below.

Duke and Kreshel (1998) describe how girls understand the mediated images of femininity targeted to them in teen magazines, and examine how the discourse of femininity in teen magazines might influence girls' self-concepts. They discuss the traditional feminine role in the USA, which includes "the adherence to cultural fashion and beauty standards". They claim teen magazines give the message that "ideal beauty is within anyone's reach, if one tries hard enough" (p. 48). 
Shields and Mayhew performed a semiotic analysis on how fashion advertising works (Shields, 2001). They state that attractiveness or ideal female beauty can be attached to any item, and this gives the item a higher value.

Labre and Walsh-Childers (2003) conducted a research on the web sites of Cosmo Girl, Teen People, Seventeen and Teen magazines. Their major finding is that the mentioned web sites identify with three major themes: beauty is a requirement, beauty can be achieved only through the purchase of products, and the magazines can help girls find the right products.

Ballentine and Ogle (2005), who conducted a content analysis study on the Seventeen magazine, indicate that since body is a key factor in defining adolescent identity, girls are especially interested in messages about the ideal beauty concept, and they may be affected more by media discourses about the body.

Findings of various studies suggest that teen magazines often contain articles on how various parts of the body (such as hair, nails, skin) should look or smell for a girl to be socially acceptable. This type of advice was often linked to further advices on the use of specific products and brands as a solution of related problems. Ballentine and Ogle (2005) report that the ideal body is described as "smooth, trim, toned, tight, long, lean, flat, strong, young, sexy, healthy, clean, free of odor and certain types of hair" (p. 290). They also report that adolescents place higher importance on appearance than adults, media presents "highly stylized and idealized images of the body", and gives messages that "emphasize the desirability of a well-maintained body" (p. 281). 
In her study on 13 and 14 year-old girls in England, Coleman (2008) conducted focus group and individual interviews. Girls discussed their relations with media images in the focus group and they discussed the relations between their past, present and future bodies in the individual interviews. She argues that "the body/image, subject/object model often relies on and reinforces a relation of media effects" (p. 164).

Rita Felski (2006) analyzed a book by Bonnie Adrian. According to Felski, Adrian's book is a notable contribution to cross-cultural aesthetics and debates over gender and globalization. Adrian mentions gigantic bridal photographs which are obligatory for marrying couples in Taiwan. They are taken before the wedding. The bride has to undergo a long make-up and hair-styling session before the photograph is taken. Breast and hip padding, special lighting and extensive retouching transforms the bride's appearance into a glamorous supermodel.

In an analysis on anthropologist Rebecca Popenoe's book, Felski (2006) states that Azawagh Arabs of Niger consider fatness to be a sign of beauty and the key to being sexually desirable, and they fatten women to the point where they cannot even move. This is contrary to the western beauty standards and it shows that ideals of beauty may vary dramatically across cultures. However, societies likes this are very rare and in all the western societies and in many other cultures around the world, beauty standards are close to the western white beauty definition (Darling-Wolf, 2004; Tu, 2007; Crawford, 2008). 
Interestingly, even when women from the local ethnical minorities (African Americans) in the US are portrayed as objects of beauty, their features are close to the western white Caucasian ideals (Meenakshi, 2005). So, teenagers and women belonging to these minorities are not happy with their racial characteristics like curly hair and dark skin color, and they use beauty products to look like white Caucasian women (Hooks, 1993).

As TV shows and movies produced in the US and Europe started dominating TV programs and movie theaters of other countries, the western standards of beauty white skin, yellow hair, blue eyes, straight hair, and slender bodies - became globally accepted. International women's and girl's magazines also played a role in this.

The study by Darling-Wolf (2004) indicated that although Japanese women criticized media representations of women, their definitions of physical beauty and attractiveness matched the western beauty ideals. One of her subjects, asked how she thought Japanese ideals of feminine beauty had changed since her mother's generation, said the ideal was Japanese earlier, but now it is the Western ideal.

Similar transformations on the ideal beauty concept can be observed in the Chinese society. When China was invaded by the British in the middle of the nineteenth century, traditional notions of Chinese national identity were undermined and white beauty standards "began to displace traditional Chinese beauties as objects of desire". Chinese pictorials "attracted readers with photos of Western beauties". New competitions like beauty pageants (for example, the Miss Shanghai competition, 
starting from 1946) were an "imitation of the Western (culture)" (Xu and Feiner, 2007, pp. 312-313).

Some studies on beauty in Turkish should also be mentioned here. These studies include the research of Atik and Örten (2008) who interviewed women and men of ages 20-30 and report that on one hand, media, fashion, music and cinema industries, on the other hand, family, friends and partners effect the formation of the beauty myth, and the fashion and cosmetics sectors play a bigger role in this. İnceoğlu and Kar (2009) interviewed 30 women who had aesthetic surgery for finding out their understanding of beauty. Their findings show that the articles published in the female magazines on beauty and body are shaping their beauty perception. Also, the most common expectation from plastic surgery operations is the desire for "feeling more beautiful" and \%60 of interviewed people say that they can have another plastic surgery operation.

\subsubsection{Identity}

Theories of identity were first developed in the 1950's. These theories defined identity as a fixed and stable characteristic of a person (Petersen, 2000). Theories developed recently reject this view and define identity as an attribute acquired through the socialization of the individual. Therefore, one's identity is not fixed and there is scope for transforming identity through further social processes. For instance, post-modernist thinkers believe that individual identity is constructed socially, and it is made up of differing and often contradictory components. Identity is multiple and it is changing. Individuals are the product of class, gender, race, ethnicity, nationality, age and so on (Williams, 2003). 
Petersen (2000) mentions one view of identity as follows:

identity is conceived as a fixed and stable characteristic of the person. It reflects the notion that one can know who someone really is. In the second view, identity is ... acquired through socialization or the internalization of imposed social roles. .. identity is not so deeply inscribed in the psyche of the individual, and so there is scope for transforming identity (p. 262).

Human beings develop a social identity early in their lives. This social identity includes our choices in categories like gender and relationships, jobs and profession, political affiliation, ethnicity and religion. (Baron, Byrne \& Johnson 1998). One's social identity may change in time, especially with changing choices or factors.

By looking at identities of others, we decide whether we like them or not. For example, if someone is supporting the same political party, we feel closer to that person. Similarly, if a teenager girl is reader of a certain girls' magazine, she may feel closer to another teenager reading the same magazine. One's behavior is influenced by the gender identity and gender roles developed by one's self. As indicated by Baron et al. (1998):

Perhaps the most pervasive element of personal identity is that portion of social identity in which each of us is assigned to one of two categories: male or female (p. 87).

According to Queer Theory (Petersen, 2000):

Identities are always multiple and there is literally an infinite number of ways in which the components of identity can combine. Furthermore, any specific identity construction is arbitrary, unstable, and exclusionary (Petersen, 2000, p. 263).

In developmental psychology, identity is defined as a mature self-definition. Erikson defines identity as follows "the major developmental hurdle that adolescents face is 
establishing an identity - a firm and coherent sense of who they are, where they are heading, and where they fit into society" (quoted in Shaffer, 2002, pp. 440-444).

On the other hand, some researchers do not agree with this point of view. For instance, Bjornerud mentions that "identity is never a fixed and real thing, but it is always an imaginary identification" (cited in Mutlu, 1998, p.206).

The psychoanalytical theory questions whether identity is a unified and coherent concept or not. For example, gender should be considered to interact with racial, class, ethnic, and sexual factors to shape personal identity (Williams, 2003, p. 60).

James Marcia's work (1966) proposes four identity statuses: identity diffusion, foreclosure, moratorium, and identity achievement. In the identity diffusion status one has not yet resolved or thought about identity issues and also has not identified future life directions. In the second status, foreclosure, the person has made a commitment to an identity, but this lacks the decision on what really suits him/her the best. In the third status, moratorium, individuals start experiencing an identity crisis trying to find what really suit them the best and are looking for answers to questions about life commitments. In the last status, identity achievement, individuals have made their personal commitments about goals, beliefs and values and thus, have resolved identity issues.

Rowe and Marcia (1980) claim that for 12 years old, $70 \%$ are in identity diffusion status, while $30 \%$ are in foreclosure status. For 15 years old, $10 \%$ move to identity achievement status, while the percentage of those in identity diffusion status is reduced 
to $60 \%$. For 18 years old, $40 \%$ are in identity diffusion, $25 \%$ are in foreclosure, $10 \%$ are in moratorium, and $25 \%$ are in identity achievement status.

Philip Meillman measured the identity statuses of males between ages 12-24 (cited in Shaffer, 2002, pp. 440-444). He observed that, contrary to the assumption of Erikson which said identity crisis is often resolved by age 15 to 18 , a big majority of 12 to 18 year olds were identity-diffuse or foreclosed. Even for 18 year olds, only $25 \%$ were in moratorium or identity achievement status.

Steele and Brown (1995) note that use of mass media and identity formation are closely related: "Adolescents' sense of who they are and who they may someday want to become plays a central role in their use of media" (p. 572). So, adolescents choose the media they want to use according to their identity formation.

On the other hand,

Mass media and the cultural views presented by mass media are also an important source for possible identities. In the period which covers childhood to adolescence, mass media and cultural insights presented by them are used heavily in determining both what they can become, and how others conceive them (p. 572).

Shields and Mayhew (2001) discuss how fashion advertising plays a role in producing female identity. They argue that American woman see repeated images of perfect bodies in ads, films, magazines, TV and on billboards. These messages are not just dictating what a woman should look like, but also they are forcing her to buy. Fashion magazines, women's magazines also convey this message through written text. 
Their research suggests that women do want to look like the models they see in the ads, they do many things to achieve the perfect look, including buying clothes and dieting, and their relationships with advertising are highly complex and constitute a "female gaze".

Female images in advertisements mostly contain an invisible, implicit male who approves of the feminine ideal. So, the point-of-view is almost always that of an implied male spectator, referred to by feminists as the "male gaze". Then the female spectator becomes a split-subject: she looks at the object of the sight, but she is also like the object of the sight. Their study shows rather than viewing themselves as subjects of their own femaleness, women view themselves as objects to be improved upon for the "male other". Then, "envy and jealousy become dominant feelings, and women feel a need to emulate, displace or eclipse the beauty of the other women" (p. 244).

Teenagers are in a part of their lives where they are constructing their identity and they have many conflicting identities that must be resolved. They have to take many important decisions for the rest of their lives, for instance, which profession is most suitable for them. In gaining their gender roles, they put a lot of emphasis on stereotype figures and prejudices reflected by the society. In taking these important decisions, they should stay away from stereotypes and prejudiced influences from the society and instead make use of their own judgments, talents and interests.

Teenage girls are still learning about the world. They are in a developmental stage, exploring and forming their identity. So, teenage girls may be particularly vulnerable 
to media messages (Gordon, 2004). She explains that messages given in teen magazines on femininity can 'limit young girls' conception of themselves and the ideas about what it means to be a woman" (p. 11).

Peirce (1993) performed a content analysis of the fiction in Seventeen and Teen magazines. Her research showed that "few of the stories offered anything but traditional socialization messages for teenage girls" (p. 59). In more than half of the stories, the main character but depended on someone else to solve her own problems. Almost half of the problems appearing in stories were about relationships with boys. Also, "all but 2 of the 44 occupations mentioned in the stories were stereotypically portrayed" (p. 59).

There is considerable research indicating that women's magazines and teen magazines promote stereotypes and lack important issues like helping teenagers learn basic properties of professions. As for gender decisions, according to magazines, there is male boys and female girls. In the society we observe people with other types of gender choices like gays and lesbians, but magazines prefer to ignore those people.

Kroger (1997) performed a study to find out whether gender plays a role in issues related to identity structure, content, developmental process, and context. She states that in terms of identity structure, men and women are not different in approaching key identity-defining issues.

However, in a later study, Sally Archer (1993) claimed that identity formation is more difficult and painful for females due to external barriers to development. Archer 
actually pointed out that females are very concerned about balancing career and family demands ( $84 \%$ showed great or some concern), while $75 \%$ of males showed no such concern.

Marnina Gonick $(1996,1997,2003)$ conducted notable research studies on teen magazines, subject positions they offer to girls, and identity construction of teenage girls. She indicates that teen magazines participate in the construction of particular meanings about what it is to be an adolescent girl. Gonick examines contradictory discourses available to girls while they are negotiating their identities.

\subsubsection{Body Image / Body Satisfaction}

This section discusses what kind of body satisfaction concept is imposed upon girls and young women by magazines and why. These two important issues are among the research questions considered in this study.

In old times, cultures assessed women by not only their appearance, but also by their experience (i.e., in giving child birth), inner beauty, and other qualifications in the society. However, after the 1950's, these virtues unfortunately became secondary to the female body appearance, and in consumption societies of today, body image is an issue of major importance (Silvestre, 2009).

The looks promoted in teen and women magazines cultivate an ideal beauty concept in young adolescents. Youngsters believe that a woman looks good only if she carries most of the body properties found in cover models and celebrities. 
Grogan and Wainwright (1996) argue that "young women have learned about the acceptability of the slim body in Western society (and the unacceptability of the body that does not fit the slim ideal)" (p. 671). They add that even at ages as young as 8 , girls speak about dieting as a means of trying to attain a slim body.

They also explain that girls in adolescence period are experiencing changes in their body in terms of shape and size and they may "find it particularly diffcult to challenge dominant cultural representations of femininity at a time when they are still learning about what it means to be a woman in society" (p. 672).

Stice and Shaw found out that after looking at magazine pictures showing ultra-thin models, female university students said they feel depression, stress, guilt, shame, insecurity and dissatisfaction with their bodies (cited in Baron et al., 1998). It is important to find out why girls and young women feel dissatisfaction with their bodies when they come across pictures of models in magazines.

Sauer and Robles-Pina indicate that teen magazine messages like "you must look thin" may cause behaviors such as eating disorders (2003). They try to assess girls' selfperception of attractiveness, and try to assess the effect of articles, advice columns, advertisements and pictures in teen magazines on the perception of the physical self. Their main findings are: the young women surveyed read beauty and fashion magazines about once in a month, mostly perceive themselves as being overweight even when they are not, and some exhibit unhealthy diet habits. 
Another problem teenage girls face is that during the puberty period, girls gain weight in the lower torso, hip and thigh regions. This puts them into a difficult situation as it might be interpreted as a "deviation from cultural ideals of female beauty" (Ballentine \& Ogle, 2005, p. 282).

Teen magazines may contribute to a reduced degree of self-confidence in girls "by inviting self-comparison to textual images of feminine perfection" (Duke, 2000, p. 273). "Girls, who are more likely to judge themselves based on their physical attractiveness, suffer declining self-esteem and estimations of their attractiveness in adolescence" (p. 273). Thus, it seems that in order for a girl to feel satisfied of her, her physical image should also be close to ideal body.

The desire to look thin and beautiful like fashion models, has some side effects. For instance, eating disorders and feeling overweight although having a normal weight are two problems which are becoming more common among teenagers. Women report numerous childhood experiences in which they were teased by peers and their family about their weight. Meyers (1999) claims that representations of women in popular media affect women. For example, the idealization of thinness has been linked to potentially deadly eating disorders like bulimia and anorexia.

Jones, Vigfusdottir, \& Lee (2004) have demonstrated that for teenage girls, there is a mediated relationship between "appearance magazines" and body dissatisfaction. Their study was performed in USA on 433 girls of 12-15 years of age. Compared to boys of similar age, girls were more engaged with appearance magazines, reported 
more appearance conversations, endorsed greater internalization of appearance ideals, and were more dissatisfied with their bodies.

Martin and Peters (2005) have conducted a study to investigate adolescent girls' knowledge about beauty types valued in the American culture, including product and brand associations. By using photos of models, girls categorized beauty types and indicated their preferences. They indicate that "comparing ones physical attractiveness to that of models in advertisements can have a negative effect on self-perceptions and self-esteem" (p. 392).

Coleman (2008) performed a focus group and interview study with thirteen 13 and 14 year old girls. One of her interviews was an "image-making session” (p. 169) in which using some magazine images supplied to them, girls created images of their own bodies. One of her aims was to find out how girls' experiences of bodies are shaped by the influence of teen magazines and popular culture. She states that magazines show impossible images of women's bodies and this causes girls to feel depressed and dissatisfied of their bodies.

Tiggemann (2012) explains that as the ideal beauty is virtually impossible to achieve, women and girls are disappointed and this causes body dissatisfaction.

Other studies (Silvestre, 2009; Smolak, Levine \& Thompson, 2001) indicate that body dissatisfaction may pose an important threat to the mental and physical health of teenage girls. 
Pressure from peers may also be an important factor influencing teenage girls and young women. In their study on undergraduate college students, Vonderen and Kinnaly (2012) state that "peer attitude toward thinness is the primary factor associated with internalization of the thin ideal" (p. 51).

Therefore, literature on body image and body satisfaction shows young girls believe that a woman should carry body properties similar to cover models and celebrities. By comparing one's body to that of impossible images of women's bodies in magazines can have a negative effect on self-perceptions and self-esteem, and girls may feel depression, stress, and dissatisfaction with their bodies.

\subsubsection{Consumption and the Media}

Emphasis on cultural ideals of feminine beauty has led to heavy consumption for beauty especially after the industrialization period. The cosmetic and fashion industries are developed by women's need for make-up and fancy clothes to look good in order to reflect their social status and to meet the body standards.

Before the end of $19^{\text {th }}$ century, the primary purpose of women's magazines used to be supplying information to women on daily life, discussing their problems, and concentrating on entertainment issues. However, later, also with the effects of globalized consumer economy, women became major consumers of goods. In accordance with that, women's magazines started devoting large sections to consumer goods, mainly fashion and beauty products, and attracted a lot of advertisements. Roger (1997) states that studies show, in the $20^{\text {th }}$ century, women spend some $80 \%$ of the total money spent on consumer goods. Accordingly, nowadays, there is a "close relationship which exists between advertising, the consumer goods industry, and the 
crucial economic role of women as consumers" (Ceulemans \& Fauconnier, 1979, p. 7). Since women are now major consumers, advertisers use the ideally beautiful female image in order to persuade women to buy.

Women's tendency of heavy spending for beauty and fashion continued during the first decade of the 21 st century. However, trying to reach an unattainable ideal beauty promoted by media, modern women are claimed to be unsatisfied with respect to their ancestors, as indicated by Wolf (1991): "More women have more money and power, but in terms of how we feel about ourselves physically, we may actually be worse off than our un-liberated grandmothers" (p. 10).

In consumer societies, what you own, what you wear becomes the determining factor for your social relationships. Nowadays women feel that they must look beautiful both to give a good impression to others at work and to be popular in their social environment. Individuals are classified according to what products they consume or wear and the beauty system creates hierarchies among women. Being trendy and wearing well-known international brand products put your position high up in the society.

Some research on the relationship between consumption and media will be summarized below. One such study is by De Beauvoir (1993), who comments about the consumption patterns of American girls in the second part of 1940's stating that "a large part of the working girl's budget is assigned to beauty care and clothes" (p. 561). She continues with remarks on how what you wear may place you up in the hierarchy: 
the better showing a woman makes, the more she is respected; the more necessary it is for her to work, the more advantageous it is for her to appear prosperous; smart appearance is a weapon, a flag, a defense, a letter of recommendation (p. 561).

Similarly, Shields and Mayhew (2001) state that image of gender in fashion ads are "highly structured cultural codes" in the late $20^{\text {th }}$ century capitalism. The transfer of codes of "ideal female beauty or attractiveness" to commodities has become common sense. The sign of ideal female body can be attached to any commodity in order to lend the commodity "value".

Nowadays, producers of various goods make use of market research such as Teen Market Profiles (Magazine Publishers of America, 2004) for outlining buying habits of teenagers. Advertisers make use of this consumption tendency of teenagers cleverly, to sell more and more of their products Teenager girls and even children are targeted with wisely planned advertising campaigns. Advertising surveys show that teen magazines are very important in shaping the consumption decisions of teenagers (MRI Teenmark, 2003).

On the other hand, research on consumer theory has not yet given enough attention to fashion and beauty spending by women, teenager girls and tweens (children with ages between 7 and 12). As Cook (2008) points out, in most of the early consumer theory discussions, the consumer was "decidedly adult" and "undoubtedly male". (p. 227). Even in recent books and articles on consumption theory, not much is said about women, "women's place and experience remain as exceptions" (p. 228). On the other 
hand, youth are covered in some recent cultural studies works, but mainly from a subculture point of view.

When it comes to children, they are "virtually invisible, barely mentioned in the passing” (p. 225). Instead, children's presence and practices must be acknowledged and investigated as an important part of consumer theory. Although there has been an important number of publications on consumer preferences and culture of children since 1990's, Cook points out that “... researchers have not made a point of situating children's consumption and the consumer culture of childhood in relation to consumption theory" (p. 221).

At the beginning of 2007, the Society and Business Review magazine has published a special issue on child and teen consumption. The guest editor of the issue, de La Ville (2007), explains that in order to study the field of child and teen consumption, one has got to consider it as a mixed system, formed of strongly correlated six systems covering social, institutional, technological, narrative, economic and political dimensions. The social relations subsystem covers the family, the peers and the teachers. The institutional system includes the school and the family with regards to providing the skills to integrate the youngster successfully into the society. The technological system includes the media - television, magazines, computers and the Internet, radio, recorded music and communication through mobile phones. The narrative system brings together stories, heroes, celebrities and other characters from real life. The child often refers to these in expressing himself/herself and to exercise his/her judgments. The economic system includes children-oriented markets. People who design products or marketing strategies for children and teens are the main actors. 
Finally, the political system plays an important role through the social construction of values that are "good" or "preferable" for that specific society. These values will play an important role in product selection of teenagers and children.

De La Ville (2007) also states that consumption habits of children and teens are "shaped and transformed by a mix of managerial action, public policy, cycles of technological change, the evaluation of related institutions like parenthood and schooling, changing cultural references, values, modes of socialization, as well as by the actions of children and teens themselves", and consumption habits of children and teenagers are shaped by a complex interrelationship of these factors. (pp. 7-14).

She then explains that social scientists started studies on the role children play in family consumption only after 1950's. Interestingly, it was scientists from the fields of marketing and consumer behavior who were the first to study teen consumption by exploring topics like consumer socialization of children, and formation of preferences about products and brands. These studies have shown that "children develop a set of social standards relating to consumption in a given cultural context - such as search for identity, membership within a group or of belonging to a social class" (pp. 7-14).

One study by Nailer (2011) on semiotic analysis of women in North Cyprus life-style magazines indicates that most of women representations are portrayed through traditional roles such as mother, spouse or partner, in contrast to the few nontraditional roles in the advertisements. 


\subsubsection{History of Magazines}

Women's magazines and teen magazines are important role-players for the consumer society which resulted from the globalization and spreading of capitalism on a world scale. For this reason, I have performed a literature review section on the history of women's and girls' magazines.

With the second part of the $18^{\text {th }}$ century, the capitalist system started getting globalized by extending trade of multinational corporations. This trend got accelerated in the $19^{\text {th }}$ century with colonization. In the $20^{\text {th }}$ century, new right and neo-liberal policies gained support and as globalization in economy increased, the world became a single market (Dağtaş, 2003, p. 13).

Many women's magazines were published in the $19^{\text {th }}$ century, but there were no teen magazines until 1940's. In that century, women were the main consumers of clothes and beauty products. Women's magazines gave them advices on how to look good, what to wear, and how to perform good housekeeping. In Turkey, women's magazines were first published in the second part of the $19^{\text {th }}$ century, but became popular at the beginning of the $20^{\text {th }}$ century (Yapar, 1999).

\subsubsection{Women's Magazines in the World}

A discussion and a chronological summary of women's magazines within political and economic developments that took place in the world may help one to understand when, how and why the print media started showing an interest in women's issues and to understand the developments leading to the current market of women's and girls' magazines. 
In the 18th century, women began a movement for freedom and started taking more responsibility in political and economic arenas. As a result of this, at the beginning of the 19th century, the improving importance of women in social life helped women's magazines to emerge as a new form of media. Early women's magazines concentrated on home and family life, fashion and appropriate manners.

The first women's magazine was La Muse Historique which was published in 165065 in France. However, Yapar (1999) states that this magazine was actually targeting men rather than women.

The Spectator (1711) was another early popular general magazine published in USA which had a sister magazine for women called The Female Spectator (Seneca, 1993).

The first magazine published specifically for women was Courrier de La Nouveaut (1758, France) (Yapar, A., 1999, p.24). The first American popular women's magazine was Godey's Ladies Book, which was published between 1830 and 1898. It was also the first magazine to approach the standard format of today's women's magazines (Seneca, 1993, p.1). 


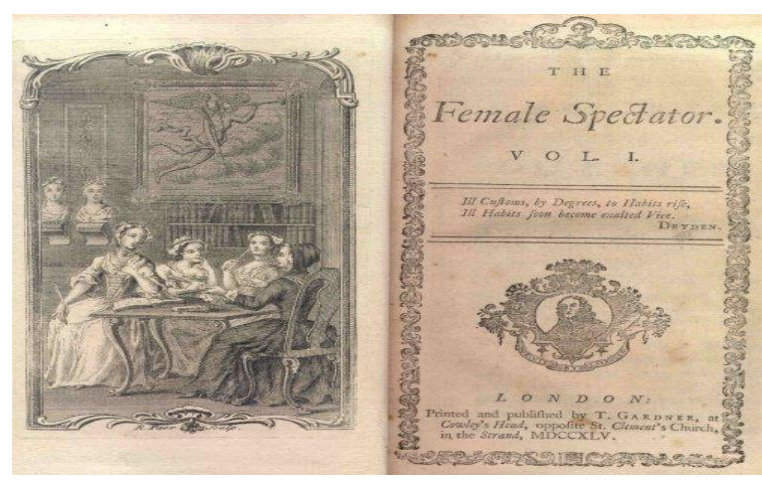

http://umich.edu/ ece/student_projects/fem ale_journalism/femalespectator.htm

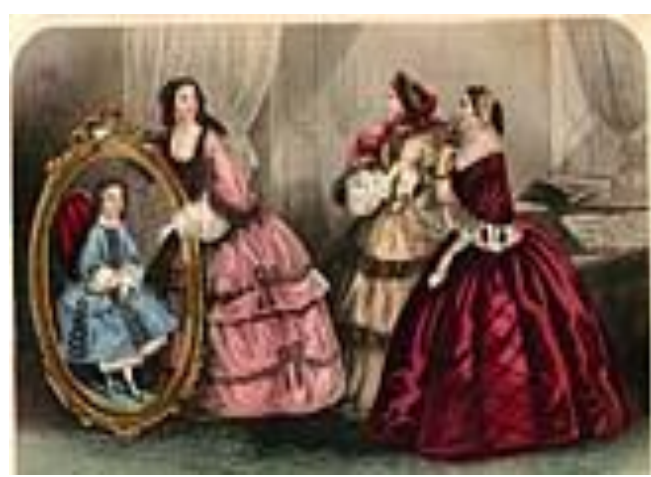

http://rarebookhistory.umwblogs.org/book/ godey\%E2\%80\%99s-lady\%E2\%80\%99sbook-volume-74-and-75/

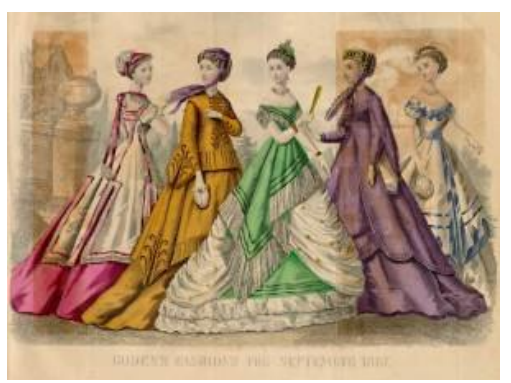

http://www.uvm.edu/ hag/godey/images/glb01-59c.jpg Figure 1: The Female Spectator and Godey's Ladies Book

The Cosmopolitan Magazine was founded as a "family" magazine by Schlicht \& Field in 1886. In the first edition, Paul Schlicht explained that the magazine would include a section "devoted exclusively to the interests of women, with articles on fashions, on household decoration, on cooking, and the care and management of children, etc., also a department for the younger members of the family". Within a year Cosmopolitan reached a circulation of 25,000. However, Schlicht \& Field went out of business in March $1888^{1}$.

\footnotetext{
${ }^{1}$ https://en.wikipedia.org/wiki/Cosmopolitan_(magazine)
} 


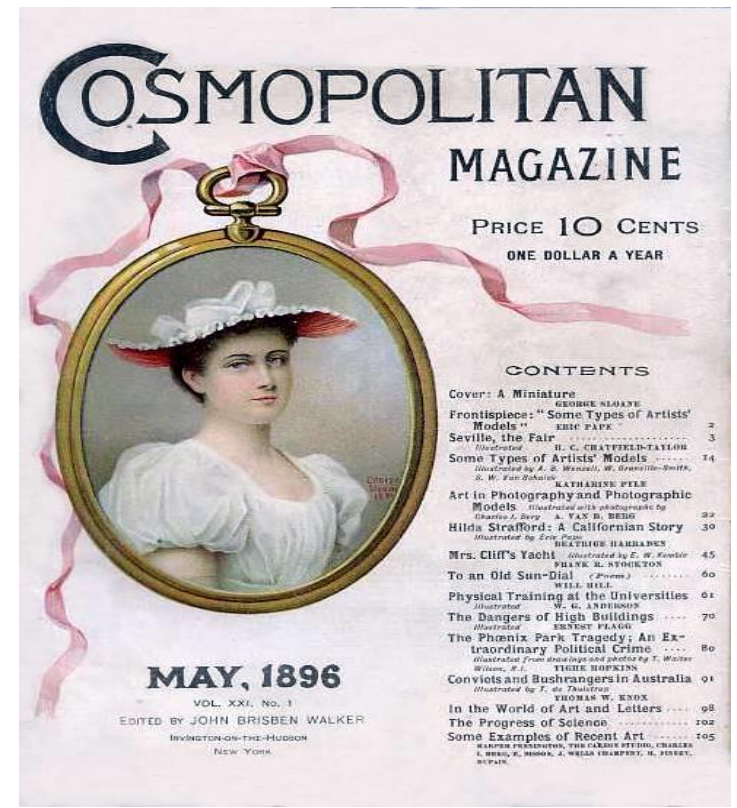

https://thesocietypages.org/socimages/2010/04/26/guest-post-the-evolution-ofcosmopolitan-magazine/

Figure 2: Cosmopolitan Magazine, May 1896, Sample Cover

The magazine was bought by E. D. Walker, from Harper's Monthly, became the new editor in 1888. He introduced serial fiction, book reviews and color illustrations. In four years, Walker tripled the circulation and Cosmopolitan became one of America's leading magazines. William Randolph Hearst purchased Cosmopolitan for $\$ 400,000$ in 1905 . By the 1930s the magazine had a circulation of $1,700,000$ and an advertising income of $\$ 5,000,000$. Circulation of Cosmopolitan reached over 2,000,000 copies during the Second World War. In the 1950s there was a decrease in the demand for fiction and the circulation of the magazine dropped dramatically. The size of the Cosmopolitan was reduced. Although circulation was only just over a million in 1955, the magazine was still profitable.

Towards the end of the 20th century, there was a growing trend in the magazine sector to publish magazines concentrating on a single area or issue. This approach is also 
observed among women's magazines. Separate publications emerged on fashion, working women, mothers, cooking and teenage girls. (Yapar, A. 1999, p.15)

For women's magazines of latest years, Hermes (1995) reports that there are three subgenres: Traditionally oriented magazines, feminist magazines and gossip magazines, with large differences. Gossip magazines are usually "tasteless", and come in a low-price range. Feminist magazines are mostly monthlies and in higher prices. Traditionally oriented magazines are either weeklies with a strong emphasis on practical advice and a moderate price range, or are monthlies in the high price range. These magazines are mostly franchised and appear in different countries and in different languages. Examples are Cosmopolitan, Vogue, Elle and Marie Claire magazines.

\subsubsection{Women's Magazines in Turkey}

Similar to the information given above on women's magazines published in the world, a discussion and a chronological summary of women's magazines within political and economic developments that took place in Turkey may help us understand when, how and why the print media started showing an interest in women's issues and to understand the developments leading to the current market of women's and girls' magazines in Turkey.

The first Turkish publication targeting women was Terakk-i Muhaddarat (1868) which was the supplement of Terakki newspaper. The first Turkish women's magazines were Ayine and Vakit yahut Mürebb-i Muhadderat which were published in 1875 (Yapar, 1999). 
Turkish women's magazines can be studied in two major periods: The Ottoman Empire period (1868-1922) and The Turkish Republic period (1922-2017).

\section{Turkish Women's Magazines in the Ottoman Empire Period (1868-1922)}

The magazines published in the Ottoman Empire period are discussed briefly by Yapar (1999, pp. 52-60). Making use of the information provided by her, these magazines are listed below in chronological order in Table 1, tabulating their name, publisher, year(s) of publication, number of issues published (if known), main contents, and importance. 
Table 1: Turkish women's magazines (1868-1922)

\begin{tabular}{|c|c|c|c|c|c|}
\hline Journal name & Publisher & $\begin{array}{l}\text { Publishing } \\
\text { Year }\end{array}$ & Issues & Contents & Importance \\
\hline $\begin{array}{l}\text { Terakki-i } \\
\text { Muhaddarat } \\
\text { (supplement of the } \\
\text { Terakki newspaper) }\end{array}$ & $\begin{array}{l}\text { Ali Reşit } \\
\text { and Filip } \\
\text { Efendi }\end{array}$ & $\begin{array}{l}28 \text { June } \\
1868\end{array}$ & 48 & $\begin{array}{l}\text { Education } \\
\text { rights and } \\
\text { work } \\
\text { opportunities } \\
\text { for women }\end{array}$ & $\begin{array}{l}\text { Women } \\
\text { audience have } \\
\text { mentioned their } \\
\text { problems with } \\
\text { letters. }\end{array}$ \\
\hline Ayine & $\begin{array}{l}\text { Mahmut } \\
\text { Hamdi }\end{array}$ & $\begin{array}{l}4 \text { Nov. } \\
1875-1876\end{array}$ & 39 & $\begin{array}{l}\text { Family } \\
\text { relationships } \\
\text { and child care }\end{array}$ & \\
\hline $\begin{array}{l}\text { Vakit yahut } \\
\text { Mürebb-i } \\
\text { Muhadderat }\end{array}$ & & 1875 & & $\begin{array}{l}\text { Useful } \\
\text { information for } \\
\text { women }\end{array}$ & \\
\hline Malumat & & & & $\begin{array}{l}\text { Fashion and } \\
\text { beauty }\end{array}$ & \\
\hline Aile & & 1880 & & $\begin{array}{l}\text { Housekeeping, } \\
\text { children }\end{array}$ & \\
\hline Hanımlar & & 1883 & & $\begin{array}{l}\text { Women and } \\
\text { children }\end{array}$ & \\
\hline Şükufezar & Arife hanım & 1886 & & $\begin{array}{l}\text { Equality of } \\
\text { women and } \\
\text { men }\end{array}$ & $\begin{array}{l}\text { The first } \\
\text { magazine which } \\
\text { has women as } \\
\text { editorial staff }\end{array}$ \\
\hline Mürü̈vvet & & 1888 & & $\begin{array}{l}\text { Education of } \\
\text { women, news } \\
\text { about women } \\
\text { of the world }\end{array}$ & \\
\hline Parça Bohçası & & 1889 & 1 & $\begin{array}{l}\text { Housekeeping, } \\
\text { child care, } \\
\text { cooking }\end{array}$ & \\
\hline $\begin{array}{l}\text { Mürebbi- } \\
\text { Mühaddarat }\end{array}$ & & & & $\begin{array}{l}\text { Raising } \\
\text { women in } \\
\text { accordance } \\
\text { with the Islam } \\
\text { religion. }\end{array}$ & $\begin{array}{l}\text { Could not } \\
\text { include some } \\
\text { articles due to } \\
\text { Sultan } \\
\text { Abdülhamit's } \\
\text { oppression. }\end{array}$ \\
\hline $\begin{array}{l}\text { Hanımlara Mahsus } \\
\text { Gazete }\end{array}$ & & $1895-1908$ & & $\begin{array}{l}\text { Women's } \\
\text { education, } \\
\text { women's } \\
\text { problems, } \\
\text { family and } \\
\text { society life, } \\
\text { health, fashion }\end{array}$ & $\begin{array}{l}\text { Authors were } \\
\text { prominent } \\
\text { intellectual } \\
\text { women of the } \\
\text { period. } \\
\text { Supported } \\
\text { women's } \\
\text { integration into } \\
\text { work force. }\end{array}$ \\
\hline Alem-i Nisvan & $\begin{array}{l}\text { Supplement } \\
\text { of Tercüman } \\
\text { newspaper }\end{array}$ & 1906 & & $\begin{array}{l}\text { Education of } \\
\text { Moslem } \\
\text { Women }\end{array}$ & $\begin{array}{l}\text { Published in the } \\
\text { Caucasian area. } \\
\text { Published } \\
\text { pictures. }\end{array}$ \\
\hline Demet & $\begin{array}{l}\text { Cenap } \\
\text { Şahabettin }\end{array}$ & 1908 & & $\begin{array}{l}\text { Problems of } \\
\text { women's' } \\
\text { education }\end{array}$ & $\begin{array}{l}\text { Male authors } \\
\text { signed their } \\
\text { work with } \\
\text { women names } \\
\text { to encourage } \\
\text { women to } \\
\text { mention their } \\
\text { own thoughts. }\end{array}$ \\
\hline
\end{tabular}




\begin{tabular}{|c|c|c|c|c|c|}
\hline \multicolumn{6}{|l|}{ Table 1. (continued) } \\
\hline Kadın & $\begin{array}{l}\text { Süleyman } \\
\text { Bahri }\end{array}$ & 1908 & & $\begin{array}{l}\text { Women's } \\
\text { rights and } \\
\text { freedom. } \\
\text { Published } \\
\text { pictures. }\end{array}$ & $\begin{array}{l}\text { Published in } \\
\text { Selanik. } \\
\text { Authors } \\
\text { included } \\
\text { famous } \\
\text { politicians and } \\
\text { people from } \\
\text { literature } \\
\text { circles. }\end{array}$ \\
\hline Mehasin & $\begin{array}{l}\text { Mehmet } \\
\text { Rauf }\end{array}$ & 1908-1909 & & $\begin{array}{l}\text { Supported } \\
\text { education of } \\
\text { and learning } \\
\text { professions by } \\
\text { women. }\end{array}$ & $\begin{array}{l}\text { Reflected } \\
\text { western fashion } \\
\text { and published } \\
\text { pictures. }\end{array}$ \\
\hline Kadin & & 1911 & 13 & & With pictures. \\
\hline Musavver Kadin & & 1911 & 7 & $\begin{array}{l}\text { Political and } \\
\text { scientific } \\
\text { issues targeted } \\
\text { for women. }\end{array}$ & \\
\hline Erkekler Dünyası & & & & $\begin{array}{l}\text { Proving that } \\
\text { women are } \\
\text { also valuable } \\
\text { in science and } \\
\text { literature. }\end{array}$ & With pictures. \\
\hline Kadınlık Hayatı & & 1913 & & $\begin{array}{l}\text { Science and } \\
\text { literature. }\end{array}$ & $\begin{array}{l}\text { Run by women } \\
\text { staff. }\end{array}$ \\
\hline Kadınlar Dünyası & $\begin{array}{l}\text { Ulviye } \\
\text { Mevlan }\end{array}$ & & 208 & $\begin{array}{l}\text { The changing } \\
\text { status of } \\
\text { Ottoman } \\
\text { women in } \\
\text { society, } \\
\text { Support for the } \\
\text { need for } \\
\text { women's } \\
\text { education, } \\
\text { issues on law. } \\
\text { Included } \\
\text { translations } \\
\text { from other } \\
\text { languages. }\end{array}$ & $\begin{array}{l}\text { The publication } \\
\text { of Müdafaa-1 } \\
\text { Hukuku Nisvan } \\
\text { Association. } \\
\text { Published } \\
\text { pictures of } \\
\text { Moslem women } \\
\text { for the first } \\
\text { time. Authors } \\
\text { were women. } \\
\text { First feminist } \\
\text { magazine that } \\
\text { could run for } \\
\text { many issues. }\end{array}$ \\
\hline Kadınlar Alemi & $\begin{array}{l}\text { Mahmut } \\
\text { Ekrem }\end{array}$ & 1914 & & $\begin{array}{l}\text { Extensive } \\
\text { literary } \\
\text { content. }\end{array}$ & With pictures. \\
\hline Hanımlar Alemi & & 1914-1918 & 32 & & With pictures. \\
\hline Kadınlık & & 1914 & $\begin{array}{l}5 \\
\text { months }\end{array}$ & $\begin{array}{l}\text { Support of } \\
\text { women's } \\
\text { rights. }\end{array}$ & \\
\hline Seyyale & & & & $\begin{array}{l}\text { Scientific and } \\
\text { literary } \\
\text { magazine for } \\
\text { women and } \\
\text { young girls. }\end{array}$ & $\begin{array}{l}\text { Philosophy and } \\
\text { ethic issues are } \\
\text { covered. }\end{array}$ \\
\hline Siyanet & & 1914 & & $\begin{array}{l}\text { Economics } \\
\text { issues are } \\
\text { covered. }\end{array}$ & \\
\hline
\end{tabular}




\begin{tabular}{|c|c|c|c|c|c|}
\hline $\begin{array}{l}\text { Table 1. (ctd.) } \\
\text { Bilgi Yurdu Işı̆ğ }\end{array}$ & $\begin{array}{l}\text { Hanımlar } \\
\text { Bilgi Yurdu } \\
\text { Müessesi }\end{array}$ & 1917-1918 & $\begin{array}{l}17 \\
\text { months }\end{array}$ & & $\begin{array}{l}\text { Published an } \\
\text { insert called } \\
\text { "Ders Kısmı". }\end{array}$ \\
\hline Türk Kadını & & 1918 & 21 & & $\begin{array}{l}\text { Included poetry } \\
\text { and short } \\
\text { stories. }\end{array}$ \\
\hline Genç Kadın & & 1919 & $\begin{array}{l}5 \\
\text { Month } \\
\text { S }\end{array}$ & $\begin{array}{l}\text { Scientific and } \\
\text { literary } \\
\text { magazine }\end{array}$ & $\begin{array}{l}\text { Male-female } \\
\text { relationships } \\
\text { discussed. }\end{array}$ \\
\hline Diyane & $\begin{array}{l}\text { Çerkez } \\
\text { Kadınları } \\
\text { Teavün } \\
\text { Cemiyeti }\end{array}$ & 1920 & 1 & $\begin{array}{l}\text { Scientific } \\
\text { content }\end{array}$ & $\begin{array}{l}\text { Published in } \\
\text { Turkish and } \\
\text { Circasian } \\
\text { languages. }\end{array}$ \\
\hline $\begin{array}{l}\text { Kadınlar Oyuncak } \\
\text { Değildir }\end{array}$ & & 1919 & & Humour & $\begin{array}{l}\text { First (and only) } \\
\text { humour } \\
\text { magazine for } \\
\text { women. }\end{array}$ \\
\hline İnci & $\begin{array}{l}\text { Sedat } \\
\text { Simavi }\end{array}$ & 1919-1921 & 37 & $\begin{array}{l}\text { Covers men's } \\
\text { thoughts on } \\
\text { women, } \\
\text { fashion, } \\
\text { beauty, poetry } \\
\text { and letters } \\
\text { from readers. }\end{array}$ & $\begin{array}{l}\text { Cover with } \\
\text { coloured } \\
\text { women's } \\
\text { photos (modern } \\
\text { Ottoman } \\
\text { women). (firstly } \\
\text { illustrations, } \\
\text { then real } \\
\text { photos) }\end{array}$ \\
\hline Hanım & $\begin{array}{l}\text { Sedat } \\
\text { Simavi }\end{array}$ & 1921 & & $\begin{array}{l}\text { Women, living } \\
\text { room, family. } \\
\text { Letters from } \\
\text { readers, short } \\
\text { stories. }\end{array}$ & $\begin{array}{l}\text { Extensive use } \\
\text { of pictures. }\end{array}$ \\
\hline Yeni İnci & S. Simavi & 1922 & & & $\begin{array}{l}\text { Continuation of } \\
\text { Inci }\end{array}$ \\
\hline
\end{tabular}

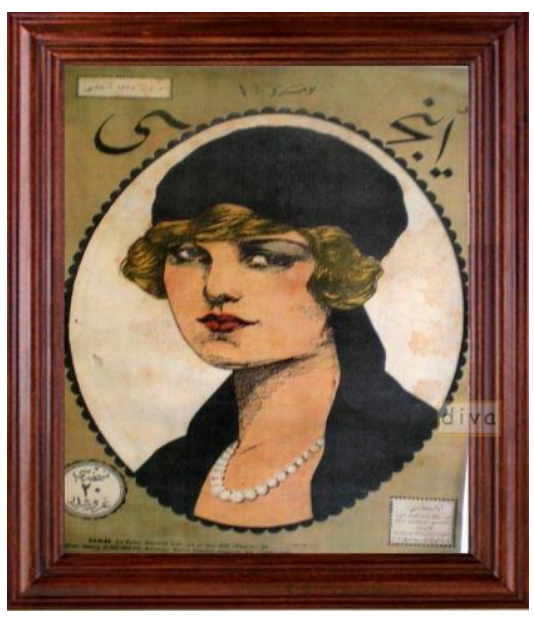

http://gulsenko.blogspot.com.cy/2012/03/turkiyede-dergicilik.html Figure 3: Cover Page of Inci Magazine 
During the last 50 years of the Ottoman Empire, Ottoman women were influenced by the world Feminist movement. In 1869, Terakki-i Muhaddarat magazine was published as the first Ottoman women's magazine. Many women's publications followed this magazine and a number of associations were established to fight for women's rights. Şükufezar, published in 1886, was the first magazine to defend the idea that men and women are equal, and it had women editorial staff. Authors of Hanımlara Mahsus Gazete, published between 1895 -1908, were prominent intellectual women of the period and it supported women's integration into work force.

The total number of women's magazines and newspapers reached 40 before the declaration of the Turkish Republic in 1923. Hanımlara Mahsus Gazete, Şükufezar, Demet, Mehasin, Kadın, Kadınlar Dünyası are among the most prominent of these publications. These publications helped Ottoman women express themselves as individuals, express their problems, get rid of their shyness to write, and helped them have their voices heard and ideas published (Çakır, 2007) .

It should be noted that during this period, the only two publications which aimed to have young teenager girls as a part of their audience were Seyyale and Bilgi Yurdu Işı̆̆ı magazines. Seyyale concentrated on issues such as philosophy, ethics, and lecture notes, while Bilgi Yurdu Işı̆̆g (1917-1918) gave lecture notes'supplements and tried to support young girls in secondary high school education.

Following the $1^{\text {st }}$ Constitutionalist Period (Meşrutiyet), women's magazines started including fashion and beauty issues. After the start of the First World War in 1914, there was an increase in the number of publications, but circulations started to decline. 
The magazines gave up their primary purpose of education, and making profit became as their main purpose. During the First World War, a heavy censorship was imposed on the press. People were fed up with news about the war, and they showed more interest in magazines which covered less politics, less news, and more humor and more magazine news (Yapar, 1999).

\section{Turkish Women's Magazines in the Turkish Republic Period}

With technical advances between World War I and II in printing, like new offset technology, magazines were able to publish more and higher quality pictures and they became more popular among the public (Yapar, 1999). Notable women's magazines published from the declaration of the Turkish Republic in 1923 to 1950 are: Murrahhis (was the first publication which gave presents as promotional goods), Hanımlar Alemi (1929) (the first Turkish women's magazine published with the new Turkish alphabet in Latin letters) Cumhuriyet Kadın Dergisi t was one of the most important women's magazine of the period. It published articles on family life and the position of women in the Turkish society, Moda Albümü (1936) and Model that emphasized women's outlook. They included foreign movie stars, celebrities and western fashion trends, Okul Klzı (1937) was a weekly political opinion, art and culture magazine, Kadın Gazetesi was a weekly magazine which included issues on sexuality for women. It also included articles on fashion, magazine, daily events, politics, social life and education.

After the Democrat Party won the elections in 1950, magazines for the whole family members like Hafta, Yirminci Asır, Resimli Hayat, Yelpaze, Hayat became popular. They mostly covered issues such as celebrities, fashion, magazine news and photonovel (fotoroman). Some notable Turkish women's magazines published in the 1950- 
1970 period are: Burda Moda (1951), Kadın Güzelliği(1951), Yelpaze(1952), Genç Klz (1963), Cep Fotoroman(1968) and Sevgilim(1969) (Yapar, 1999).

A comparison between one of the most popular magazines of this period, Yelpaze, and todays women's and teen magazines reveals that earlier magazines covered more topics and published articles that could be read by the whole family members. For instance, in Yelpaze magazine, translations from famous authors of the world literature such as Athur Miller and Anton Cehov were printed. (Yelpaze, 1960 October, 1963 January). Foreign and national celebrities occupied a more or less even space. Their format was larger than todays' magazines with a size bigger than A4. However, they are quite poor in paper and printing quality compared to today's magazines.
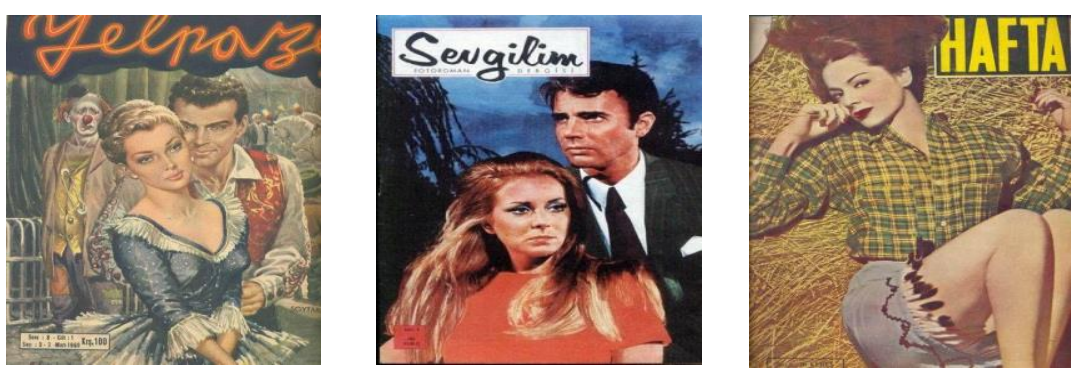

Figure 4: Sample Covers of Yelpaze, Sevgilim and Hafta Magazines. Pictures by the author, from personal collection.

During the 41 year period from 1970 to 2011 , more than 80 women's magazines have been published in Turkey. Kadınca (Womanly) and Kim (Who) were the most popular magazine in this period. Kadınca is started publication in 1978, Kim was launched in 1992. Duygu Asena, a famous Turkish feminist figure who passed away in 2006, was the chief editor of both magazines for a long duration. 
Kirca (2001) performed a textual analysis of 1995 issues of two contemporary Turkish magazines Kim and Kadınca. Kırca states that Kim and Kadınca magazines attempted to cover feminist issues and to establish a female consciousness in line with feminist politics. She indicates that these two magazines had a traditional layout, and they were similar to traditional women's magazines when the language they were using is considered. Like other women's magazines, they covered articles on relationships, sex, beauty and fashion. However, they also proposed strategies for improving daily lives of women, and covered editorial articles on women's equality with men. Both magazines emphasized the importance of economic independence and urged women to fight stereotyped sex roles. So, Kim and Kadınca magazines also had some positive impact on Turkish women with regards to individual freedom and gaining conscience about stereotyped sex roles dominant in the society.

Kirca (2001) criticizes the magazines by saying that "although messages about women's freedom and self-esteem are dominant in Kim and Kadınca, the primary driver behind the magazines is not improving women's lives but making profit to survive in the competitive market system.” (p. 10) Kadinca quit publication in 1998, and Kim ceased publication in 1999.

Pazartesi, Eksik Etek, and Mavi Çorap magazines that were published in this period were feminist magazines, concentrating on women's independence issues, without much concern about circulation matters, which makes them different from the other women's magazines. 


\subsubsection{Teen Magazines}

Similar to women's magazines, teen magazines will be explained in two subsections: Teen magazines in the world, and teen magazines in Turkey.

\section{Teen Magazines in the World}

Teen magazines are magazines specifically aimed at teenage readers. Their contents are mostly fashion, shopping tips, beauty issues, news and interviews with celebrities, tests about relationships and personality. Magazines for teenagers - like the word "teenage" itself - is a terminology of the late 1950s and early 1960s. This was the period of "Cold War", when the world was politically and economically divided into two as the "western" capitalist bloc and the "eastern" communist bloc, with a few countries like India, Yugoslavia, and Egypt remaining as "non-aligned”.

In the second part of the twentieth century, western societies became consumer societies. From 1985 to 1990 consumer spending doubled (Wolf, 1991). Large shopping malls were developed in the US and the Western World, and young girls were given higher allowances which they could use for shopping on their own. Producers of beauty and fashion products discovered that these youngsters could potentially spend considerable amounts of money on their products. For example, Japanese advertisers identified young women to have the most disposable income in the 1970s (Darling-Wolf, 2004).

So, companies started advertising their products for teenagers and teen magazines were published for the promotion and advertising of beauty and fashion products. Various studies have shown that teenage magazines are indeed very effective in promoting and advertising cosmetic products (Duke \& Kreshel, 1998; Duke, 2000; Hendrix, 2003). 
It is important to note here that young women ranked magazines only after friends as the most influential source of information in a study on what they believed was the most effective medium for advertisers in reaching their age groups (Davalos et al., 2007).

Willemsen (1998) states that magazines for teenage girls are very gender stereotypic, while gender-oriented magazines for teenage boys are quite rare. The general interest magazines for teenage boys generally cover topics of special interest like computers, or are music publications which are aimed at both boys and girls.

In the United States the Seventeen Magazine started publication in 1944 and it was the first teen magazine published, specifically targeting the needs of teenagers and informing them on various issues. The promotion of the magazine raised an awareness of teens on the part of marketers, advertisers, and suppliers of goods targeting teens. The starting idea was from Helen Valentine, who envisaged a "service and fashion magazine for high school girls" (Massoni, 2011, p. 7). She was Seventeen's first editor-in-chief for six years. 


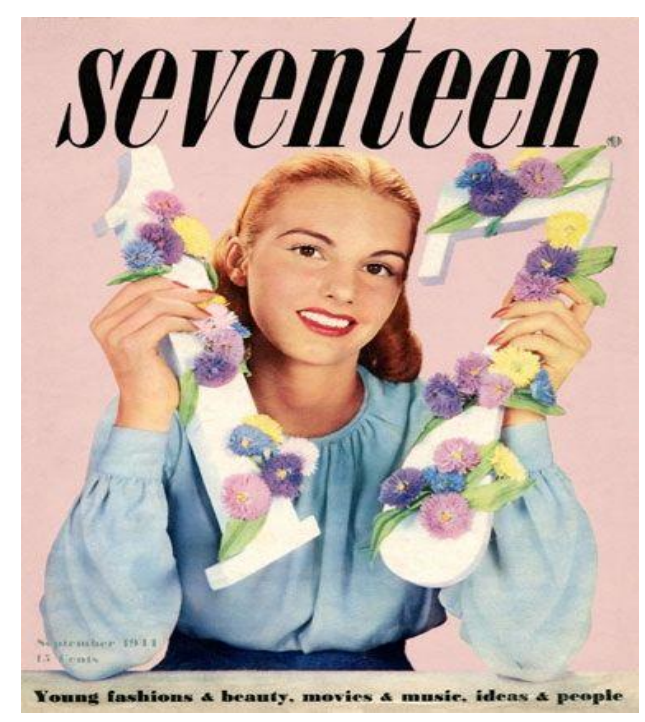

http://www.seventeen.com/celebrity/g1713/65th-anniversary-cover-archive/?slide=1 Figure 5: Sample Cover of an Early Edition of Seventeen Magazine (1944).

Seventeen remained under Triangle Publications until it was sold to Rupert Murdoch ${ }^{2}$. The magazine was then sold in 1991 to Primedia company, and then to the Hearst Corporation (William Randolph Hearst) for $\$ 182.4$ million (). Honey is regarded as the first teen magazine published in the UK in 1962. Its first motto was: "For the teens and twenties" ${ }^{3}$. At its peak time, it sold as high as 250,000 copies per month but then the sales went down and the magazine was closed announcing it was being merged to the 19 magazine in 1986.

The traditional "big three" teen magazines of the US market were Seventeen, YM and Teen. These magazines had a combined readership of more than 6 million, which is quite notable in a country with a population of 300 million. Then after 1999, three new teen magazines, which are all offspring of successful adult magazines: Cosmo Girl (Cosmopolitan), Elle Girl (Elle) and Teen Vogue (Vogue) were launched and the teen

\footnotetext{
${ }^{2}$ https://en.wikipedia.org/wiki/Seventeen_(American_magazine)

${ }^{3}$ https://en.wikipedia.org/wiki/Honey_(magazine)
} 
magazine sector became more competitive. Consequently, advertisement revenues went down and circulations started to decline (Tyre, 2004).

It should be noted that the teen magazine sector has been in a decline in terms of sales of printed copies at newsstands since 2008. This decline appears to be in parallel with the rise of the Internet, with teenagers preferring online web sites and social networking sites in order to keep up with the latest trends and fashions, and to follow gossip and news on their favorite celebrities. As a result, traditional teen magazines, published on a weekly or monthly basis, "are unable to compete with online news sites and social networks, which provide up-to-the minute news and trends". However, there is still some possibility for growth within this sector. For example, Condé Nast group published two new teen magazines: Teen Tatler and Miss Vogue. This move follows "the highly successful launch of Teen Vogue in the US" (Research and Markets, 2013).

In UK, the Sugar teen magazine which was closed in 2011 after its owner said it was no longer profitable. Sugar's circulation went down to an average of 113,320 a month from a high of 422,179 in the first half of 2000. On the other hand, there were similar declines in other print magazine sectors such as men's magazines, and the technical and game magazines. Sugar's closure was blamed on teenagers spending more time on the Internet with their mobile phones and the web as they could get the content for free of charge. This is an issue which also affected the music industry for some time (Plunkett, 2011).

Hachette Filipacchi media group blamed the Sugar closure on teenagers spending more time on their mobile phones and the web who "increasingly expect to receive content 
for free". It is an issue that the music industry - along with most media owners - has been struggling with for some time. However, there is an expectation that online web sites of magazines can stay alive and still bring in revenue. For example, Coleridge, who launched iPad applications for both Vogue and Wired magazines, has predicted that "up to $40 \%$ of the publisher's sales will one day come from tablets" (Plunkett, 2011). Similarly, although it is not printed anymore, the Sugar magazine's website, Sugarscape.com has around 430,000 unique users a month, even surpassing its highest circulation in 2000 , cited above.

In Amazon's best seller list of teen magazines, Seventeen and Teen Vogue currently occupy the top two positions ${ }^{4}$. Seventeen's circulation (the number of copies distributed, on average, for each issue) is listed as 2,000,585 as of June 2017, the $29^{\text {th }}$ in the list of all magazines sold in USA. Teen Vogue's circulation is $1,007,108$, and it is the $74^{\text {th } 5}$.

\section{Teen Magazines in Turkey}

The first teen magazine of Turkey is Hey, which was published in 1970. It was a weekly music, film, fashion-youth magazine. Other Turkish teen magazines following Hey were published in the middle of 1980's. This interestingly coincides with the liberalization policies of Turgut Özal's governments which were formed after the military coup of 1980. Also, first big shopping malls were established in Istanbul and Ankara in early 1990's. (Ak Merkez, Atakule, Galleria) Those were the times when the Turkish market was further open for international products, including beauty products and popular brands for youngsters such as Adidas, Nike, and Converse.

\footnotetext{
${ }^{4}$ https://www.amazon.com/Best-Sellers-Magazines-Teen/zgbs/magazines/602368

${ }^{5}$ https://en.wikipedia.org/wiki/List_of_magazines_by_circulation 
Before 1980, the majority of Turkish teenagers did not wear international brand products. As one result of the liberalization policies after 1980, the majority of teenagers in Turkey and Northern Cyprus now prefer to wear brand clothes and shoes produced by popular international companies.

Looking at the Turkish political background in the 1980's, the most notable event is the military coup of September 1980. This was followed by the dissolving of the national assembly, a large number of arrests and the suspension of some civil rights. Many daily and weekly newspapers and magazines had to stop publication for various durations under decrees from the military. Some editors were jailed and put on trial. Under these conditions, Turkish media gave more emphasis to magazine coverage after the 1980 coup as there was considerable pressure on publishing political news and social issues (Dağtaş, 2006).

Another important issue of the post-1980 coup media in Turkey is the changes in the ownership of media companies. Businessmen like Aydın Doğan (Milliyet, Hürriyet, D\&R magazines, Kanal D TV etc.), Turgay Ciner (Sabah group, ATV) and Cem Uzan (Star group) took over media companies and TV stations and many newspapers lost their independence (Dağtaş, 2006).

Teen magazines published after 1980 were Blue Jean by Hürriyet Group (1986), Hey Girl (1988) by Milliyet Yayın Group, She + he (1994) by 1 Numara Yayıncılık (Sabah Periyodik Yayınlar), Cosmo Girl (May. 2002), by 1 Numara \& Hearst, and Go Girl and Chica, published by Doğan and Egmont Yayınc1lık. Milliyet newspaper publishes an insert for girls every Wednesday called Salsa. In North Cyprus, the T2E 
magazine was the first and only teen magazine. It was published by Arkitera Ltd., and its owner was Alev Şensoy. The table below lists the Turkish teen magazines ${ }^{6}$.

Table 2: Turkish teen magazines (Until 2007).

\begin{tabular}{|c|c|c|}
\hline $\begin{array}{l}\text { Name of Turkish teen } \\
\text { magazine }\end{array}$ & First published in & $\begin{array}{l}\text { Published by (first publisher in } \\
\text { parenthesis) }\end{array}$ \\
\hline Hey (closed) & 1970 & \\
\hline Blue Jean & 1986 & (Hurriyet Group) DBR \\
\hline \multicolumn{3}{|l|}{ Free (closed) } \\
\hline \multicolumn{3}{|l|}{ Onyedi (closed) } \\
\hline \multicolumn{3}{|l|}{ Boom (closed) } \\
\hline \multicolumn{3}{|l|}{ Walkman (closed) } \\
\hline Stüdyo İmge (closed) & 1985 & \\
\hline Gençlik (closed) & & Supplement of Güneş Newspaper \\
\hline Stretch (closed) & & Supplement of Sabah Newspaper \\
\hline \multicolumn{3}{|l|}{ TV'de 7 Gong (closed) } \\
\hline \multicolumn{3}{|l|}{ Heavy Metal (closed) } \\
\hline Rock Kazanı (closed) & 1990 & \\
\hline Akgenç (closed) & & Akbank \\
\hline \multicolumn{3}{|l|}{ PopCorn (closed) } \\
\hline Hey Girl & 1988 & (Milliyet Yayin Group) DBR \\
\hline Top Pop (closed) & & (Hurriyet Group) \\
\hline \multicolumn{3}{|l|}{ Number One (closed) } \\
\hline She \& He (closed) & 1994 & (1 Numara Yayıncılık) Sabah Gr. \\
\hline \multicolumn{3}{|l|}{ Popsi (closed) } \\
\hline Cosmo Girl & 2002 & Sabah Group \\
\hline Go Girl & & Dogan and Egmont \\
\hline Chica & & Dogan and Egmont \\
\hline Dream (closed) & 2006 & Dream TV \\
\hline Yüxexes & & Dream TV \\
\hline Rolling Stone & & Sabah Group \\
\hline Salsa & & $\begin{array}{l}\text { Supplement of } \text { Milliyet } \\
\text { Newspaper }\end{array}$ \\
\hline Trendy & & $\begin{array}{l}\text { Supplement of Hürriyet } \\
\text { Newspaper }\end{array}$ \\
\hline Seventeen (closed) & & Sabah Group \\
\hline T2E (closed) & 2006 & Arkitera Ltd. \\
\hline
\end{tabular}

\footnotetext{
${ }^{6}$ When forming Table 2, information from the following web page is also used: https://onedio.com/haber/bir-donem-gencligin-elinden-dusurmedigi-en-populer-genclik-ve-muzikdergileri-623548
} 
According to our findings outlined in Chapter 4 and findings of other researchers, the recent trend is that girls start reading magazines from very young ages (Vares \& Jackson, 2010). This is reflected by the fact that a series of magazines for different age groups are now being published. Now, there are magazines in North Cyprus and Turkey like Barbie for 6-9 years old, magazines such as Go Girl for 10-12 years olds. Teen magazines like Hey Girl and Cosmo Girl are prepared for an audience of 15-17 years old. There are no teen magazines for boys published in Turkey and North Cyprus.

\subsection{Related Theories}

\subsubsection{Feminist Theory}

One of the issues contested by feminist movements is that the society continually forces young girls and women to comply to the image of "feminine beauty" (Wolf, 1991). According to many feminist scholars, this is one of the reasons why teenagers become heavy consumers of brand clothes and beauty products. These points of view closely match my stance, hence the feminist theory and research conducted by various feminist movements and scholars on beauty is discussed below.

Individually, women have been demanding equal rights since 1600's. However, an organized movement for this purpose was first observed in America during the Women's Suffrage movement of the 1848. This movement represents the first stage in the organized demand for political equality. First books and newspaper articles specifically written for women also appeared during the Suffrage movement (Code, 2003).

Early feminist movements were more "liberal" in their nature. John Stuart Mill's statement of liberal feminism influenced the first feminists who asked for equal rights 
with men to education, voting rights for women and rights to own property. However, Mill indicated that only "exceptional" women should be allowed to workforce, which was to be criticized sharply by later feminist movements (Nash, 2002)

According to some researchers, during the $20^{\text {th }}$ century, there were three 'waves' of feminist movements. The first wave was in late 1930's, the second one in late 1960's and early 1970's and the third wave started during the 1990's. Each one of these waves had different leading issues and messages, distinguishing them from each other (Schlenker, Caron. \& Halteman, 1998).

Feminism earlier concentrated on political issues, such as voting rights and equality of women in social life. Later, "uneven distribution of power and privilege" in the society on gender basis (McPherson, K. 2003, p.208) was considered and, known as the women's liberation movement, it became a worldwide action. The main aims were to oppose sexual discrimination in the society, to call for a greater emphasis on women's issues and the right for birth control.

More recently, feminists acknowledged race, class, sexuality, religion and age differences among women of the world. Also, lately, feminists "made their mark by bringing girls' issues and multiple girls' standpoints to the forefront" for the first time and they "were especially concerned with issues facing adolescent girls and young women" (Starr, 2003, p. 474).

Recent feminist movements identified the so-called "Barbie Doll syndrome": women should look a certain way: thin and attractive (Purdy, 2005, p. 161). Freidan (2013) 
criticizes this misleading statement as follows: “...experts told (women) how to catch a man and keep him... how to dress, look and act more feminine" and adding that the message given to young girls and women was:"(all they) had to do was to devote their lives ... to finding a husband and bearing children.” (p. 2) Girls are also taught from an early age that they should look 'most beautiful' to males.

Feminists interpret sex and gender differently: "sex and gender are not simply variables to be put into equations, but they are complex factors that require careful attention to their formation" (Dow and Condit, 2005, p. 454).

Recently, feminist work in academic circles in the field of communication grew considerably. Some specific areas explored by feminist researchers are the body images displayed on the TV and magazines, the portrayal of women in advertisements, and gendered language patterns in advertisements directed at youngsters (Dow and Condit, 2005).

Other feminist movements to note are radical feminism and socialist feminism. Radical feminists seek to abolish male-domination in society (patriarchy) by challenging existing social norms and institutions, instead of a purely political process (Willis, 1984). They challenge traditional gender roles, opposing the sexual objectification of women. On the other hand, socialist feminists challenge consumerism and inequality of women's status in the society. They have started community initiatives for better childcare provision, for safer streets, and better academic opportunities for women in higher education (Thom, 2002). 
The Turkish feminist movements were analyzed in detail by Kara (2000). She mentions that feminist movements succeeded in bringing together women from different social and political movements under the topic of women's rights. In 1990's, problems of women started being discussed in many institutions and appeared in programs of some political parties. Also, some feminist newspapers and magazines were published. However, up to our knowledge there is no feminist research on Turkish girls' magazines.

A comprehensive study on fiction written for women in patriarchal societies is "Reading Romance” (Radway, 1991). Joke Hermes (1995) has published a book on reading women's magazines. She states that she has a postmodern feminist standing. As an activity of understanding the society, she decided to perform a study on how women's magazines are read. She states that in earlier work on women's magazines, Freidan said women's magazines have a mystic power to keep women within their homes and Tuchman stated that the ideal woman is described as passive and dependent, and this influences young women in a negative way. Hermes indicates that these early studies on women's magazines did not take into consideration the opinions of magazine readers, they just contained an analysis of the text.

After the 1980's, post-structuralism and postmodernism led to the acknowledgement of "pleasure" as an important aspect of popular culture studies and cultural studies started including the readers' perspectives as well. Hermes (1995) mentions that magazine readers may be taking pleasure from what they read considering the fantasies appearing in stories. She agrees with many other researchers that women's magazines are still predominantly heterosexual in orientation and white in color. 
On the other hand, considering cinema products, Laura Mulvey (1989) mentions that the image of woman is used as passive raw material for the active gaze of man, in line with the patriarchal order. Similarly, messages in magazines direct adolescent girls to try to make themselves attractive for young men considering how they would be viewed through the 'male gaze'. Trying to get closer to ideal beauty standards, they do make-up and purchase beauty products in order to make themselves more attractive for the young men.

As teen magazines can actually "shape the world of a teenage girl" (Peirce, 1993, p. 66), they should include more nontraditional messages to show their readers that there are other options, women are not confined to a few limited roles and occupations can become less gendered. Freidan (2013) claims "somehow, somewhere, someone must have figured out that..." if women are kept as housewives, they will buy more things (p.2 43).

When young girls find out that they cannot attain ideal beauty standards, they start disliking some physical features of their body and they get depressed. For example, Sauer and Robles-Pina's (2003) study shows that young women read beauty and fashion magazines about once in a month, mostly perceive themselves as being overweight even when they are not, and some exhibit unhealthy diet habits.

\subsubsection{Media Effects}

As cited in (Güngör, 2013), first studies on media effects by Lippmann and Lasswell date back to 1920's. Lasswell investigated the powerful propaganda of USA and UK during the first world war using the newspapers. This was followed by the "hypodermic needle theory" in 1930's and 1940’s, following the Payne Fund studies, 
focusing on the impact of motion pictures on children. This theory, also known as the magic bullet theory, claimed mass media had a direct, immediate and powerful effect on its audiences. Several factors contributed to this powerful effects theory of communication, including: "the fast rise and popularization of radio and television, and the emergence of the persuasion industries, such as advertising and propaganda." (University of Twente, 2017)

Hitler's powerful propaganda system using radio and newspapers during WWII to unify the German public behind the Nazi party supported this theory of powerful effects. The theory suggests that the mass media could influence a very large group of people directly and uniformly by 'shooting' or 'injecting' them with appropriate messages designed to trigger a desired response.

Nowadays, it is believed that communication research on media effects has gone through four stages. The first phase covers the studies of Lippmann, Lasswell and the hypodermic needle theory as explained above and researchers believed that media had considerable power to shape the public opinion.

In 1930's, researchers started experimental studies (first, on influence of films on children and youngsters) on media effects. This is considered as the start of the second phase, which continued until 1960's. In this phase, it was realized that social, cultural, environmental and psychological factors should also be taken into consideration in media effects research. "Media were shown to operate within a pre-existing social relationships and a particular social and cultural context” (McQuail, 2005, p. 458). The second phase concluded that media had limited effects. However, with the advance of 
new media and Internet, this finding was to be challenged later in third and fourth phases.

When television became popular towards the beginning of 1960's, researchers realized its importance in social life and started reconsidering more serious effects of media one more time. This was the beginning of the third phase. This time, attention was on long-term effects of media, and social processes and media processes were considered at the same time. Researchers were also interested in the details of media organizations, their ownership structures and how messages were "shaped" before they were delivered to audiences.

Although the first girls' magazine, Seventeen, started publication in 1944, the theme magazines for teenage girls became popular in 1960's, which coincides with the third phase of media effects research on teen magazines Honey, Jackie, and 19.

The fourth phase is considered to begin in late 1970's, with the introduction of the "social constructivist" approach. This approach views media as "having their most significant effects by constructing meanings. These constructed meanings are then offered in a systematic way to audiences, often shaped by prior collective identifications" (McQuail, 2005, p. 460). Then, meanings are constructed by the receivers of messages, who are in strong influence from their social environment. So, both the constructed meanings and the social structure determine how a certain person is going to be affected by the messages. This approach is closer to Cultural Studies research. 
However, there is great difficulty predicting what these effects will be, or in proving that these effects are due to the influence of the media. McQuail reports that with recent advances in communications research, we are "in a better position to say when effects are more or less likely" (p. 456). One difficulty in performing media effects research is it is hard to distinguish between effects on knowledge and opinion (cognitive), effects on attitude and feelings (affectual) and behavioral effects. It is also hard to tell which type of effect is more significant than others (McQuail, 2005, p. 465). McQuail reports that media can cause an unintended change, an intended change, a minor change, can facilitate change, can reinforce the existing beliefs or views, or can prevent change. Effects can further be classified into two dimensions, planned/unplanned and short term/long term.

With the beginning of the new millennium, Internet has become a new medium of information source. As more and more people "go online", research on effects of Internet is gaining popularity in communications studies. So, possibly we can talk about a fifth phase of media effects, which will take into account what is happening on the "cyberspace". It must be noted that, recently, social networking services like Facebook and Twitter have gained high popularity among young children and teenagers. Teen magazines now have companion online web sites, and the magazines are suggesting teenagers to take a look at some web sites they promote. Thus, new media which is reachable online, deserves more research on media effects.

Some researchers are claiming that with new media gaining higher popularity, a new paradigm is needed in communication theory. McQuail (2013) draws attention to the “... potential (of Internet) for using the ... social media as a vehicle, plus the immense 
new capacity for identifying, recording, and keeping track of target markets of consumers." (p. 226). He adds that "There is much to be gained from new technology and learned from new thinking to assist in deploying more complex and effective models of mass communication." (p. 226). However, since the aim for many communicators is still to generate consumption and profits, "the traditional notion of effect is not going to be abandoned lightly." (p. 226)

In this study, I concentrate on long term effects, reinforcement of existing beauty standards in societies and the cultivation of an ideal beauty concept among teenage girls.

\subsubsection{Cultivation Effects and the Media}

Research in the second part of the twentieth century has shown that media have an important role in shaping (cultivating) attitudes and conceptions of human beings about their environment and the world. Originally, Cultivation Theory studies were limited with the TV. Recently, some studies have expanded the cultivation concept to print media. Although cultivation research concentrated on proving the cultivation effects of TV on heavy viewers, the basic idea can also be applied to how teen magazines influence teenage girls.

Cultivation Theory was developed by George Gerbner and it claims that mass media, and in particular, television (TV), affects the perceptions of individuals (Gerbner et al, 1994). McQuail reports that among the long term media effect theories, the cultivation theory is probably the "best documented and most investigated" (2005, p. 497). 
Cultivation Theory considers television as "the cultural arm of the established industrial order". "Television serves to maintain, stabilize and reinforce, rather than alter, threaten or weaken conventional beliefs and behaviors" (i.e., the current economic order - the capitalist system)" (Gross, 1977, p. 180).

Gerbner (1992) states that:

traditional effects research models are based on selectively used media, messages and campaigns. They focus on selective exposures causing attitude change, viewer preferences, etc. They miss the essential and unique feature of television culture: its universal, stable and pervasive cultivations of perception about life and social relationships in large communities over long periods of time (p.100-101).

Since cultivation concentrates on gradual and cumulative effects, it is different than the traditional stimulus-effect studies. It has two dimensions of research. The first one "tests the consistency of the television message system" (McQuail, 2005, p. 497), while the second dimension deals with experimental research (surveys) on public beliefs about the social system. Finally, the public beliefs about reality are compared with the actual reality, taking heavy, medium or light television viewing as the main parameter.

Cultivation analysis begins with a message system analysis, "identifying the most recurrent, stable, and overarching patterns of television content", which are the "consistent images, portrayals, and values that occur in most programs and are virtually inescapable for regular (and especially the heavy) viewers”. (Gerbner, 1998, p. 181) 
Cultivation theorists focus on heavy TV viewing of individuals over a long period of time. Cultivation theory states that, heavy TV viewers tend to describe and accept the world in terms of what they see on the TV. The theory basically states that heavy exposure to mass media messages creates and cultivates attitudes more consistent with these messages. "The more time individuals spend consuming media (e.g., watching television), the closer their views are to the "world" created by media" (Zhang \& Chia, 2006, p. 266).

The two steps in the cultivation process are 'learning' and 'construction': TV viewing causes learning, and incidental information on TV-view of the world is accumulated by the receiver. Then, this information is used to construct social realities. Similarly, considering teenage girls who read teen magazines, teen magazine reading may cause learning while information on magazine-view of the girls' world is accumulated. This view can then be used to construct an ideal teenager girl image.

Some information about the background of Cultivation Theory is also necessary to note here. Cultivation Theory research began in late 1960's when there was a big political turmoil in the USA after the assassinations of human rights activist Martin Luther King and Senator Robert Kennedy. It was also a time of protests against the US involvement in the Vietnam War. The National Commission on the Causes and Prevention of Violence funded a research study to analyze violence in prime time TV programs. George Gerbner was appointed as the director of this project. (Signorielli \& Morgan, 1996) This first research documented how violence dominated television programs. In 1969, the US Congress decided to extend its aims to understanding the social consequences of growing up and living with TV. 
The Cultural Indicators project investigates how the flow of media messages is produced, managed, and distributed, and how exposure to the world of TV contributes to viewers' conceptions about the real world (Signorielli \& Morgan, 1996). TV viewers are classified into two categories: heavy viewers and light viewers. Heavy TV viewers are defined as individuals who watch four or more hours of TV every day. On the other hand, light TV viewers are those who view two or less hours of TV every day. These viewers are also selective in choosing programs they watch. According to 2009 A.C Nielsen Co. studies, the average American watches 5 hours of TV a day (Nielsen, 2009). So, the TV becomes the main 'educator' for many viewers.

Similarly, teen magazine readers may be classified into two categories: heavy readers and light readers. Girls who buy and read copies of at least one teen magazine regularly can be considered to be heavy readers and girls who buy and read teen magazines from time to time, or who borrow teen magazines from their friends rarely can be considered to be light readers.

Cultural indicators are messages that reflect the 'collective cultivation' of a public. Gerbner claims that four questions can determine cultural indicators of a given public (Gerbner et al, 1994). These four questions are:

1. What is? (what gets the attention)

2. What is important? (what gets the emphasis)

3. What is right? (the tendency of public)

4. What is related to what? (the question of structure, what concepts are found interrelated in messages?) 
With regards to the beauty, the beauty standards of a society can be considered to be the cultural indicators of a society.

Cultivation analysis is designed to measure perceptions of real life facts in comparison to life as shown on TV. In general, studies show that violence appears more in the TV world than in real life. For example, in the US, violent crimes are about $1 \%$ of total crimes, but on the TV, violent crimes were reported to be about 10\% (Gerbner et al., 2002). On the other hand, it is reported that "more than half of TV characters are involved in some kind of violent action every week" while FBI statistics indicate that less than $1 \%$ of Americans are victims of criminal violence (Gerbner et al., 2002, p. $52)$.

The Mean World Syndrome states that heavy TV viewers have a tendency to think the world is more dangerous than it actually is. TV shows the world as a selfish and violent place, so heavy TV viewers are frightened and are too cautious of the real world.

According to the cultivation perspective, heavy TV viewers: tend to think there are too many law enforcement employees, tend to trust other people less, experience too much fear (for example, being afraid to walk alone) and watch so much TV that they believe violence is an acceptable behavior in solving problems (Gerbner et al., 2002).

The Mainstreaming principle states that heavy TV viewers will exhibit smaller differences in perceptions, will be drawn towards a more centric view, and adopt expanded TV representations of the world. Similarly, heavy teen magazine readers may exhibit smaller differences in an ideal beauty concept. 
Cultivation Theory studies have been criticized by some communication theory researchers in 1980's and 1990's. One point of controversy was whether the effects do or do not occur, and even if they occur, whether they are limited or not. Another criticism was that other countries had different television networks and different program types, which would have different broadcasting policies, so applying it in other countries would require taking these factors into consideration.

Also, considering the recent directions of communications theory research, it has been realized by many scientists that there is a complex system of relationships between media owners, program producers, the audience, and social order and the environment. This means it is difficult to consider cultivation effects separately from the general socialization theories. On this issue, Reimer and Rosengren (1990) state that "socioeconomic background brings about a certain life-style (which) in turn leads to a specific media use, and this media use cultivates a person's values.” (p. 187).

Signorielli and Morgan (1996) report that research conducted considering cultural indicators and cultivation has already contributed to communications theory and will help scholars performing research in various fields. Morgan and Shanahan (2010) state that more than 125 studies directly relevant to cultivation have been published since 2000, and more than 500 studies have been published in total.

Cultivation approach is also used in research on print media and specifically, on teen magazines (Zollo, 1995; Duke, 2000; Hendriks, 2002; Davalos et al., 2007; Cornett, 2012). As cited in Duke, Freedman has noted, "Boys 'show off through status and power, thus signaling their potency; girls cultivate attractiveness, thus seeking 
admiration and indicating to boys their social interest." Girls learn that the right look and being nice are vital to acceptance by others. Teen magazines are thought to contribute to the socialization of girls into traditional, appearance-based standards of femininity (Duke, 2000, p. 373).

Meyers (1999) mentions a 1987 study by Elizabeth Fraser of how adolescent females interpret Jackie, a British teen magazine for girls. Fraser found that when the media's version of reality conflicted with the girls' lived reality, girls viewed the media's version as more credible and legitimate.

Some researchers adopting a cultivation theoretical approach conducted studies which indicate that messages related with beauty are conveyed over and over by peers and media to young girls and women, cultivating an "ideal beauty" concept.

It is reported that teen magazines are the second most influential source of information for teenagers after peers (Davalos et al., 2007). Young adults indicated that they believed the most effective media for advertisers in reaching their age group is magazines (Zollo, 1995). This finding strengthens the justification of studying the influence of teen magazines on teenagers' beauty standards.

There are also cultivation theory-related studies on media performed in Turkey (Batmaz, 1986; Yumlu, 1987; Özer, 2004; Özer, 2005; Taylan, 2011). Özer (2005) studied TV news programs of 4 prominent private TV stations and one state channel (TRT1), which concludes that television has a cultivation and main streaming role. Similarly, a study by Taylan (2011) states findings supporting original studies of 
Gerbner on long term violence effects of USA TV programs, for youngsters in Turkey watching Turkish TV programs.

\subsubsection{Cultural Studies}

Meyers (1999) defines culture as "the process by which meanings of self, social identity and social relations are created within the context of a particular system of hierarchical social formations" (p. 6). She says culture is inherently political. For European and US cultures, the system is "white, patriarchal capitalism", and as Fiske has pointed out, in this system, the products of popular culture "carry the interests of the ideologically dominant", and works "in favor of the status quo" (p. 7). She points out that as outlined by Althusser, Gitlin and Hall, popular media serves the interests of the ruling classes and help "to shape a world view in their audiences supporting those who hold positions of power and authority" (p. 7). Popular media promote gender stereotypes and beliefs to support the ideals, values and opinions of white, heterosexual, middle-class and upper-classmen. This prevailing ideology must appear natural and inevitable, and must look like common sense to be effective.

Hall (2001) reports that different audiences may understand media products differently. He has proposed that the process of communication should be considered together with the complex structure of social relations, and it cannot be studied as a linear sender/message/receiver model. Instead, he suggested the use of his Encoding/Decoding model of communication.

In Hall's encoding/decoding model, at the production end, the process requires the "knowledge of the technical infrastructure, relations of production and frameworks of knowledge" (p. 168). The media institutions are mostly owned by dominant power 
structures, so, "typical frameworks of meaning" at the production end, "are likely to conform to dominant power structures" (McQuail, 2005, p. 73). Communicators choose to encode messages according to their ideological and institutional position. They can manipulate the language to give their messages a "preferred reading". The product (a television news program, or a teen magazine article), which is called a “meaningful discourse" by Hall (2001, p. 168) is encoded into meaning structures, and it is broadcast. It is then received and decoded by the receiver (audience member), but the meaning structures of the receiver after decoding might be different than the meaning structures intended by the producer, depending on the receiver's sociocultural and political position within the society. Receivers can "resist ideological influence by applying oppositional readings, according to their own experience and position" (McQuail, 2005, p. 73). So, different audiences with different socio-cultural or political positions in the society will decode products into different meaning structures.

Meyers (1999) defines mediated popular culture as the "mass produced commodities" (such as television programs, books, movies, newspapers, music CD's, etc.) “created and disseminated by the media for wide consumption by various targeted segments of the population" (p. 6).

Although it is a popular research area, there are lots of discussions on issues related with popular culture. There is disagreement even on the meaning of popular culture. Milestone and Meyer (2012) define popular culture as an "amorphous concept" including many cultural products ranging from cinema to newspaper articles, from computer games to music, adding that media (mass media and new media) represents 
much of popular culture (p. 1). They explain how gender is produced, consumed and represented in popular culture.

Popular culture started to shape up as a separate discipline of study starting form 1950 's, but it has made a fast progress. In Europe and the USA, there are now many departments offering programs and courses in this area and many studies were conducted resulting in a large set of publications which shows the interest in and the importance of popular culture (Güngör, 1999).

Adorno states that popular culture can be "harmful" and can even have "toxic effects" on the society (Witkin, 2003, p. 1). Instead of using popular culture, he prefers to use "culture industry" because he thinks the products of popular culture do not come from the people, but instead they are manufactured and presented by the capitalist market for manipulating the "mass consciousness" (p. 2).

Aydoğan (2004) criticizes the culture industry stating that their products convey messages on the "fact" that the current state is the best for the society, and there is no basic need that the status quo should be criticized (p. 37). This way, the readers will feel more secure.

On the other hand, according to postmodernists, with the latest developments at the end of the 20th century, with industrial labor losing its position and the service sector gaining importance, working classes of the western world became 'fragmented', and there was a need to redefine cultural meaning. Identities were no longer based solely on the class, but could be based on sex, the body, nationality or ethnicity. Thus, "a 
critique of Marxism inside cultural studies became inevitable" (McRobbie, 1994, p. 6). She also states that women played a key role in structuring modern life and took an important role in "representing the growth of capitalist consumer culture" (p. 7).

In Turkey, studies in popular culture were started later. The 1994 book by Alemdar and Erdoğan is an important step in Turkish popular culture studies. They state that culture should not be limited with a number of areas such as theater, movies, painting, etc. Instead, it should be considered as the expression of himself/herself of humans in every area of societal life. "Using his/her accumulated life experiences and what he/she has created, the way a person 'produces' himself/herself is his/her culture" (p. 19).

They also mention that some researchers relate popular culture to the people considering the meaning of term popular. For them, popular culture is produced by people or by those 'above' the people for people (Alemdar \& Erdoğan, 1994, p. 110).

Then, who is 'people'? Some mention the majority of the population as 'people'. For them, culture is then a concept which is shared by the majority of the population. Some others define people as the working class. Hence, for them, popular culture means the culture of the workers. For those researchers, working class is the fundamental building stone of the society and thus, popular culture has a positive meaning. Others consider the working class as the uneducated, illiterate, ordinary and penniless, and state that popular culture is useless, banal and ordinary (Güngör, 1999). However, one early study on Turkish popular culture by Özbek (2003) on 'Arabesk' music and its prominent pioneer Orhan Gencebay, states that 'Arabesk' music, which is music preferred by Turkish suburban population and shanty towns in 1990's should be 
analyzed within the context of where it is produced, played, listened to and the social class it addresses, and the time frame it is consumed, without blaming it categorically as banal.

The studies in popular culture question whether it is urban or rural, whether it represents contemporary and civilized life or underdeveloped life, where it stems from, by whom is it produced and for whom, whether it is bad or good (Güngör, 1999).

In his book on popular culture in Turkey, Oktay (1993) states that until 1945, magazines published in Turkey gave importance to education and enlightenment of readers. However after the Second World War, and especially following the Marshall Plan in 1948 and the election win by the conservative Democrat Party in 1950, American life style started influencing the Turkish culture and hence the Turkish magazines. This time period can be considered to be the period in which repetitive coverage of Western Beauty ideals is observed in Women's and Girls magazines. In this period, magazines also selected being in harmony with the governing conservatives, as they mainly depended on sales for their revenue (p. 57).

I believe teen magazines also fit into the definition of mediated popular culture, as they are mass produced, and target teenage girls.

Considering the origins of teen magazines and their place in consumer society, and also considering their links to western culture, cultivation effects should be taken into consideration in this type of study. My approach in this research is mainly feminist. 


\section{Chapter 3}

\section{RESEARCH METHODOLOGY}

In this chapter, firstly the research methodologies used in this research will be defined. Then, application of the selected methodologies will be outlined. After the presentation of the sample group, the chapter will be concluded by explaining how the research is conducted.

\subsection{Research Approach}

The aim of this study is to investigate the body images of women and teenagers appearing in teen magazines and the impact of teen magazines on the beauty understanding and consumption habits of young girls. Research methods selected for the study are content analysis, survey and focus group analysis. The results are interpreted from a critical perspective, employing both the qualitative and quantitative research approaches. Hence, this study employs a mixed-method research approach. In the following subsections, basic definitions of the research approaches employed in this study will be stated.

\subsubsection{Mixed methods research}

Mixed methods research is "recognized as the third major research approach or research paradigm” (Johnson, Onwuegbuzie \& Turner, 2007, p. 112). Among the 19 definitions of mixed methods research appearing in the mentioned paper, Creswell's definition is the most direct one: "Mixed methods research is a research design (or methodology) in which the researcher collects, analyzes, and mixes (integrates or 
connects) both quantitative and qualitative data in a single study or a multiphase program or inquiry.” (p. 119).

\subsubsection{Content Analysis}

According to Arthur Asa Berger (1991), "content analysis is defined as a research technique based upon measuring (counting) the amount of something....in a random sampling of some forms of communication." The aim of the technique is by investigating the messages and communication, the researcher may gain "insights into the people who receive these messages" (p. 92). In his recent book, Berger cites Wright who defines content analysis as a research method "for the systematic classification and description of communication content according to certain predetermined categories", which may involve qualitative or quantitative analysis, or both (Berger, 2011, p. 205).

\subsubsection{Survey}

Survey research methodology includes sampling, question design and data collection components. The purpose of the survey technique is to "produce quantitative or numeric descriptions about some aspects of the study population" (Fowler, 2014, p. 1). The information is collected by asking the study population questions. The answers to these questions constitute the data for the analysis phase. Information is collected from a sample of the population, only. The sample is a small fraction of the population.

\subsubsection{Selection of Content Analysis Categories in Related Work}

For the content analysis of teen magazines, Peirce (1993) was the first to use a categorization. Willemsen (1998) added more categories by considering the regular features of the selected magazines. The categories were combined until most of the articles could be placed in a meaningful category. The basic unit of analysis was a quarter of a page. Her final set of categories are fashion, beauty, hobbies, celebrities 
and stars, health and other information, shopping tips, reports, love-sex and relationships, romantic fiction, columns, and miscellaneous (puzzles, horoscopes, letters to the editor, news items, etc.).

\subsubsection{Focus Group}

Focus group study is a qualitative method based on group interviews. A moderator guides the interview, by raising topics, while a small group of participants discusses the topics raised (Morgan, 1997). It is particularly useful when researchers seek to discover how participants give meanings to texts they read and their ways of understanding messages.

Focus group study is different from individual interviews as the questions and individual answers trigger interaction between the participants, resulting in a discussion among the participants and one answer leading to more remarks on the issue from different participants. Focus group methodology allows for discussion among the audience to obtain a better understanding of their views on various issues (Parker \& Tritter, 2006).

According to Kitzinger (1995, p. 302) interaction between participants helps:

a) To highlight the respondents' attitudes, priorities, language, and framework of understanding;

b) To encourage research participants to generate and explore their own questions and develop their own analysis of common experiences;

c) To encourage a variety of communication from participants-tapping into a wide range and form of understanding;

d) To help to identify group norms and cultural values; 
e) To provide insight into the operation of group social processes in the articulation of knowledge (for example, through the examination of what information is censured or muted within the group);

f) To encourage open conversation about embarrassing subjects and to permit the expression of criticism;

g) Generally to facilitate the expression of ideas and experiences that might be left underdeveloped in an interview and to illuminate the research participants' perspectives through the debate within the group.

\subsection{Instruments of the Study}

In the following subsections, the instruments of the study are outlined considering the three research approaches one by one.

\subsubsection{Content Analysis Study}

A quantitative content analysis study is performed to understand the messages and topics covered in teen magazines. The content analysis is used to examine stable and repeated patterns and concepts that appear in teen magazines for girls.

Two teen magazines, Cosmo Girl and Hey Girl are selected for this study. Both magazines are published in Turkey, in Turkish, and they have high circulations. Hey Girl and CosmoGirl magazines consider the 12-17 years old teenage girls as their main audience.

\subsubsection{Survey (Questionnaire) Study}

In the survey approach of this study, a questionnaire was prepared and applied to teenager girls. The questionnaire prepared by the researcher, is applied to teenage girls in the 12-17 year-old range. The survey questionnaire aims to find out information on the beauty concept, the body satisfaction and consumption habits of teenagers. It is 
used to find out teenagers' beliefs, opinions, attitudes and behaviors, trying to find out how teenagers conceive some social realities.

The questionnaire is formed of three sections. The first section, which is composed of 35 questions, aims at collecting various types of information about girls. The types of information collected by the first section of the questionnaire can be classified as follows:

a. Personal information such as age, school grades, education of mother/father, weekly allowance.
b. Information about consumption habits and brands.
c. Information about purchase and reading of girls' magazines.
d. Information about girls' perception of beauty.

The second section of the questionnaire is composed of eight questions on how girls make use of the magazines in their daily lives, with answers to be selected from five options, strongly agree, agree, neutral, disagree, strongly disagree.

The third section contains a body satisfaction inventory, adapted from (Özgür et al., 1998), which is composed of twenty-five questions. The answers are selected among options designed with a five-scale approach, very satisfied, satisfied, no opinion, not satisfied, not satisfied at all.

For the body mass index (BMI) calculations, the height and weight information of 156 girls was also collected, and their body mass index was calculated using this data. 


\subsubsection{Focus Group}

Research methods discussed above (content analysis and the survey) provided us with information on messages given and topics covered by teen magazines, and beauty understanding, consumption habits and body satisfaction of teenage girls. However, it is difficult to find out "why" and "how" these findings in a "natural discussion environment" by just using quantitative methods of research (Hansen et al., 1998, p. 257).

It has been reported that focus group research "can produce highly useful information that surveys miss" (Grudens-Schuck, Allen, \& Larson, 2004, p. 5). For this reason, the focus group method is used to collect information on issues like why and how the beauty understanding, fashion, brand products use, body satisfaction and consumption habits of teenagers who read teen magazines are shaped the way they are.

The methodology applied in this study is similar to that used by Tiggemann, Gardiner, and Slater (2000). A narrative analysis was performed on focus group discussions using an inductive approach (Frith \& Gleeson, 2004). Major focus group findings concerning the girls' consumption habits, body satisfaction, magazine reading, understanding of fashion and brands are presented and discussed.

Discussion was guided by the following questions:

1. Do you buy any teens magazines? (opening question)

2. Which parts of girls' magazines do you like most? (key question)

3. How do you define a beautiful girl? (key question) 
4. Are girls' magazines a good source of information on the issues that are important for you? (key question)

Then, other probing questions were asked for clarification and to better understand responses to the key questions. Finally, girls were asked whether or not there was anything they would like to add as an ending question.

\subsection{Population / Sample Group}

In the following subsections, the population/sample groups selected in this study are outlined considering the three research approaches one by one.

\subsubsection{Population for Questionnaire Study}

The questionnaire is prepared by the researcher, consisting of 67 questions and is applied to 156 teenage girls in the $12-17$ year-old range. The sample of the survey is restricted with teenager girls living in North Cyprus.

\subsubsection{Age Distribution}

Table 3: Age distribution of questionnaire respondents

\begin{tabular}{|l|l|l|}
\hline Age & No. of respondents & $\begin{array}{l}\text { \% of respondents } \\
(\mathbf{n = 1 5 6})\end{array}$ \\
\hline $\mathbf{1 2}$ & 21 & $\mathbf{1 3 . 5}$ \\
\hline $\mathbf{1 3}$ & 27 & $\mathbf{1 7 . 3}$ \\
\hline $\mathbf{1 4}$ & 25 & $\mathbf{1 6}$ \\
\hline $\mathbf{1 5}$ & 33 & $\mathbf{2 1 . 2}$ \\
\hline $\mathbf{1 6}$ & 23 & $\mathbf{1 4 . 7}$ \\
\hline $\mathbf{1 7}$ & 27 & $\mathbf{1 7 . 3}$ \\
\hline All & $\mathbf{1 5 6}$ & $\mathbf{1 0 0 . 0}$ \\
\hline
\end{tabular}

Table 3 indicates that the age distribution of teenage girls who answered the questionnaire is quite even. 


\subsubsection{Weekly Allowance}

Table 4. Weekly allowances of respondents

\begin{tabular}{|c|c|c|}
\hline $\begin{array}{c}\text { Weekly Allowance } \\
(1 \text { USD = 1.5 TL) }\end{array}$ & $\begin{array}{c}\text { No. of } \\
\text { respondents }\end{array}$ & $\begin{array}{c}\text { \% of respondents } \\
(\mathbf{n}=\mathbf{1 5 6})\end{array}$ \\
\hline Less than 25 TL & 32 & $\mathbf{2 0 . 5}$ \\
\hline $\mathbf{2 5 - 5 0}$ TL & 79 & $\mathbf{5 0 . 6}$ \\
\hline $51-75$ TL & 26 & 16.7 \\
\hline $76-100$ TL & 16 & 10.3 \\
\hline More than 100 TL & 3 & 1.9 \\
\hline TOTAL & 156 & 100.0 \\
\hline
\end{tabular}

Table 4. Indicates that more than half of the respondents get a weekly allowance between 25 to 50 Turkish Liras (approximately 15 to 35 USD).

\subsubsection{Mothers' Education}

Table 5. Education level distribution of mothers

\begin{tabular}{|c|c|c|}
\hline $\begin{array}{c}\text { Education } \\
\text { Level }\end{array}$ & No. of respondents & $\begin{array}{c}\text { \% of respondents } \\
(\mathbf{n}=\mathbf{1 5 6})\end{array}$ \\
\hline Primary School & 22 & 14.1 \\
\hline Secondary School & 21 & 13.5 \\
\hline High School & 77 & 49.3 \\
\hline University & 31 & 19.9 \\
\hline Graduate Degree & 3 & 1.9 \\
\hline Other & 2 & 1.3 \\
\hline TOTAL & 156 & $\mathbf{1 0 0 . 0}$ \\
\hline
\end{tabular}


Table 5. Indicates that almost half of the mothers are high school graduates. Mothers with university degrees (bachelor and graduate) make up for more 1/5 (21.8\%).

\subsubsection{Fathers' Education}

Table 6: Education level distribution of fathers

\begin{tabular}{|c|c|c|}
\hline $\begin{array}{c}\text { Education } \\
\text { Level }\end{array}$ & $\begin{array}{c}\text { No. of } \\
\text { respondents }\end{array}$ & $\begin{array}{c}\text { \% of } \\
\text { respondents } \\
(\mathbf{n}=\mathbf{1 5 6})\end{array}$ \\
\hline Primary School & 20 & $\mathbf{1 2 . 8}$ \\
\hline Secondary School & 18 & $\mathbf{1 1 . 5}$ \\
\hline High School & 75 & $\mathbf{4 8 . 1}$ \\
\hline University & 38 & $\mathbf{2 4 . 4}$ \\
\hline Graduate Degree & 4 & $\mathbf{2 . 6}$ \\
\hline Other & 1 & $\mathbf{0 . 6}$ \\
\hline TOTAL & $\mathbf{1 5 6}$ & $\mathbf{1 0 0 . 0}$ \\
\hline
\end{tabular}

Table 6. Indicates that fathers' education levels are quite similar to mothers' education levels. However, fathers with university degrees make up for more $27 \%$, which is almost $6 \%$ higher than mothers.

\subsubsection{Sample Group for Content Analysis Study}

A study conducted by the author earlier on 110 teenager girls indicated that Hey Girl and CosmoGirl magazines are the most popular ones among teenage girls aged 12-17 in North Cyprus. Although obtaining correct sales and subscription statistics are hard to find, information derived over the internet (Medyatava.com, 2006) and sales statistics of Northern Cyprus press distributors (personal communication, 2006) show that these two magazines have the highest sales in North Cyprus. 
It is interesting to note that the circulation of teenager magazines in North Cyprus is almost ten times higher in proportion to the population. Popular teenager magazines have an average circulation of 20,000 in Turkey, and considering the total population as 70 million, the circulation of teen magazines with respect to population is approximately 3 in 10,000. On the other hand, popular teenager magazines have an average circulation of 500 in North Cyprus, and considering the total population as 250,000 , the circulation with respect to the population is approximately 2.5 in 1,000 .

These statistics indicate that North Cyprus is a better setting to study the influence of teenager magazines on teenager girls as it is easier to find teenager girls who are readers of teen magazines for focus groups and other studies.

Three issues each for the 2007-2010 period of Hey Girl and CosmoGirl magazines are selected for this study. In total, 12 issues of Hey Girl and 12 issues of CosmoGirl are analyzed. Hey Girl magazine was first published in 1988 by Milliyet Publishing Group as a monthly magazine. After the takeover of Milliyet Group by Aydin Dogan in 1989, the ownership has passed to Doğan-Burda Dergi Yayıncılık ve Pazarlama A.Ş. The editor of Hey Girl is Ethel Kohen. It is published as a monthly magazine which has 100-118 pages. With the exception of a male author who prepares the "From Men's Point of View' section, all the authors are women. Content analysis study shows the format of the magazine is very similar to women's magazines.

CosmoGirl magazine was first published in 1992 in Turkey as a monthly magazine by Bir Numara Yayınc1lık. The first main theme of the magazine was "Your Best Friend". CosmoGirl was sold to Turgay Ciner's Merkez Dergi Yayıncılık in 2004 and changed 
its leading theme to "The Magazine of Free Girls". The editor is Özge Sarıkadılar. All the authors are women. It is published as a monthly magazine which has 100-148 pages.

Hey Girl magazine defines itself as follows (from the Web page of Hey Girl): "Hey Girl is a real friend for 12-19 year old girls who have just began exploring life because it both informs and entertains young teenagers with its rich contents, colored and lively presentation."

CosmoGirl magazine defines itself as follows (from the Web page of CosmoGirl): "CosmoGirl approaches its readers friendly and intimately shares their secrets and proposes solutions to their problems. It aims to educate girls while they are entertained. The main contents of the magazine are interviews with celebrities, fashion and beauty pages with high quality products which have reasonable prices, psychological articles which analyzes problems teenagers encounter related with school, family, and friends."

\subsubsection{Population for Focus Group Study}

The population of the focus group study is adolescent girls aged between 12-17 years from two schools in the city of Famagusta, North Cyprus. The focus groups from the first school, Canbulat Özgürlük secondary school, consisted of adolescent girls aged between 12-14 years. The focus groups from the second school, Gazimağusa Türk Maarif College (GMTMK), consisted of adolescent girls aged 15-17 years. GMTMK has a middle school and a high school section, and accepts students through a competitive national entrance examination. Both schools are public schools. 
In total, 82 participants were chosen to form six different focus groups, one for each age from 12-17 years. Each focus group had 12 to 15 girls, within the limits described by Morgan (1996).

\subsection{Conducting the Research}

In the following subsections, how research for this study is conducted is outlined considering the three research approaches one by one.

\subsubsection{Content Analysis}

For the content analysis study, three issues of Hey Girl and CosmoGirl magazines were selected from each year, and years 2007, 2008, 2009 and 2010 were covered. In total, 12 issues each of magazines were analyzed, making a total of 24 magazines.

A full page was taken as the basic measure in the content analysis. If more than one content category is covered on a single page (which is a very rare case), the one that appears larger than the other is selected. The categories were decided after reviewing Willemsen's study (1998). Some of her categories were merged and some new categories are added. In total, 15 categories were used in our contents analysis study:

1. Fashion

2. Beauty

3. Celebrities

4. Sex and relationships

5. Music-TV-Cinema

6. Sports and Health

7. Food and Diet

8. Editorials and cover page

9. Astrology 
10. Education and personal development

11. Shopping tips

12. Letters from readers

13. Advertisements

14. Technology

15. Other

The categories beauty and fashion include articles and news only, excluding advertisements or shopping tips about fashion and beauty products.

\subsubsection{Survey}

A questionnaire of 67 questions was applied to 156 teenage girls who were 12-17 years old. The girls were students in Canbulat Ozgürlük Secondary School, Gazimağusa Türk Maarif College and Eastern Mediterranean College, with secondary school and high school sections, all located in the city of Gazimağusa, North Cyprus. Canbulat Özgürlük Secondary School is a state school and its students are mostly from lower income families. Eastern Mediterranean College is a private school and its students are from high income families. Gazimağusa Türk Maarif College is a state school. It is one of the four special North Cyprus state schools that accept primary school graduates by a national entrance exam. Most of its students are from middle or higher income families, although there are some students from lower income families as well.

\subsubsection{Focus Group}

After obtaining permission for the study from the Turkish Cypriot Ministry of Education, a focus group study was conducted with adolescent girls aged between $12-$ 17 years from two schools in the city of Famagusta, North Cyprus. 82 participants were chosen from this sample, taking the approval of families and school 
administrations, to form six different focus groups, one for each age from 12-17 years. Each focus group comprised between 12 and 15 girls, within the limits described by Morgan as explained before (1996). Participation of the girls was voluntary upon approval from their parents.

The focus groups from the first school, Canbulat Özgürlük secondary school, consisted of adolescent girls aged between 12-14 years. The focus groups from the second school, Gazimağusa Türk Maarif College (GMTMK), consisted of adolescent girls aged 15-17 years. GMTMK has a middle school and a high school section, and accepts students through a competitive national entrance examination. Both schools are public schools.

The girls in each focus group knew one another well as they were all classmates. This meant that as they were already members of preexisting social groups, better discussion and debate were promoted (Bloor, Frankland, Thomas, \& Robson, 2000, p.23).

\section{Procedure}

Participants were informed of the topic and purpose of the study. Before the study commenced, participants sat around a table, and the moderator, who was a female researcher, gave them a short orientation on the focus group process. Then, some recent issues of teen magazines were handed out to participants, and they were allowed to read the publications for approximately 15 minutes. This allowed participants to feel comfortable and relaxed when talking to the moderator and to one another. 
The moderator chose a topic and started a discussion, followed by comments from participants. Topics were open for discussion in different orders in the focus groups. There was a prepared list of topics to be discussed. When topics had not been mentioned by participants, the moderator led the group to move from one topic to another to cover them all. Each primary question was discussed for about 15 minutes and one focus group session took approximately 60 minutes. All the discussions were noted and recorded by the moderator. Recordings were transformed into transcripts and the accuracy of the transcripts was checked by a second researcher.

A narrative analysis with an inductive approach was applied to the expressions of participants on the ways in which they make and use stories to interpret their understanding of ideal beauty, body image, and consumption behavior, as well as their motivation for reading the magazines. The research analysis was driven by surface level explicit expressions (Frith \& Gleeson, 2004) of participants. 


\section{Chapter 4}

\section{FINDINGS}

In this chapter, the findings of the three different research approaches applied in this study will be discussed with subsection 4.1 outlining survey results, subsection 4.2. outlining content analysis results and subsection 4.3 oulining focus group results. The chapter is concluded with the interpretation of the findings.

\subsection{Content Analysis Findings}

In this section, content analysis results of Hey Girl and Cosmo Girl magazines are discussed. The last part of the section compares contents of one issue of the Seventeen magazine published in US, and one issue of the Turkish Cosmo Girl magazine.

\subsubsection{Coverage of Hey Girl and Cosmo Girl Magazines}

The content analysis part of the study was conducted on two teen magazines, Hey Girl and Cosmo Girl, published in Turkey, in Turkish language. These magazines are selected considering circulation figures obtained from magazine sales statistics in North Cyprus. They are the ones with highest circulation among girls' magazines sold in North Cyprus.

For the contents analysis study of the magazines, as explained in Chapter 3, Willemsen's (1998) categories are considered. A summary of the averages of each magazine's contents over 12 selected issues spanning four years (2007-2010) and the 
general averages of the 15 content categories, considering all 24 issues of both magazines are given in Table 7, below.

Detailed figures (per issue and averages) of magazine contents according to number of pages and percentage coverage in Hey Girl and Cosmo Girl, which are used to find the averages to construct Table 7 are given in Tables B1, B2, and B3, in Appendix B. 
Table 7: Overall category averages of the content analysis study

\begin{tabular}{|c|c|c|c|c|}
\hline Category & Hey Girl & Cosmo Girl & Overall & Ranking \\
\hline Fashion & 0.94 & 2.83 & 1.83 & 11 \\
\hline Beauty & 3.94 & 2.83 & 3.30 & 7 \\
\hline Celebrities & 15.43 & 17.40 & 16.43 & 3 \\
\hline Sex and Relationships & 17.56 & 11.10 & 14.45 & 4 \\
\hline Music, TV, Cinema & 1.81 & 5.73 & 3.74 & 6 \\
\hline Sports and Health & 1.65 & 2.42 & 2.00 & 9 \\
\hline Food and Diet & 1.89 & 2.10 & 1.99 & 10 \\
\hline Editorials and Cover & 5.28 & 4.14 & 4.74 & 5 \\
\hline Astrology & 2.20 & 1.45 & 1.79 & 13 \\
\hline Educ. and Pers. Dev. & 3.39 & 2.56 & 2.97 & 8 \\
\hline Shopping Tips & 23.07 & 25.10 & 24.29 & 1 \\
\hline Letters from Readers & 1.02 & 2.62 & 1.83 & 12 \\
\hline Advertisements & 21.18 & 17.60 & 19.41 & 2 \\
\hline Technology & 0.08 & 0.00 & 0.04 & 15 \\
\hline Other & 0.55 & 2.00 & 1.18 & 14 \\
\hline TOTAL & 100.00 & 100.00 & 100.00 & \\
\hline
\end{tabular}

When the overall averages are considered, the order of categories is as follows:

1. Shopping tips $(\% 24.29)$

2. Advertisements (\%19.41)

3. Celebrities (\%16.43)

4. Sex and relationships (\%14.45) 
5. Editorials (\%4.74)

6. Music (\%3.74)

7. Beauty (\%3.30)

8. Education and personal development (\%2.97)

9. Sports and health $(\% 2.00)$

10. Food and diet (\%1.99)

11. Fashion (\%1.83)

12. Letters from readers $(\% 1.83)$

13. Astrology (\%1.79)

14. Other (\%1.28)

15. Technology (\%0.04)

Combined together, the first four categories, shopping tips, advertisements, celebrities and sex and relationships cover almost $75 \%$ of girls' magazine pages.

Figure 6 is a graph showing the overall average coverage of each category in magazines use in this study. 


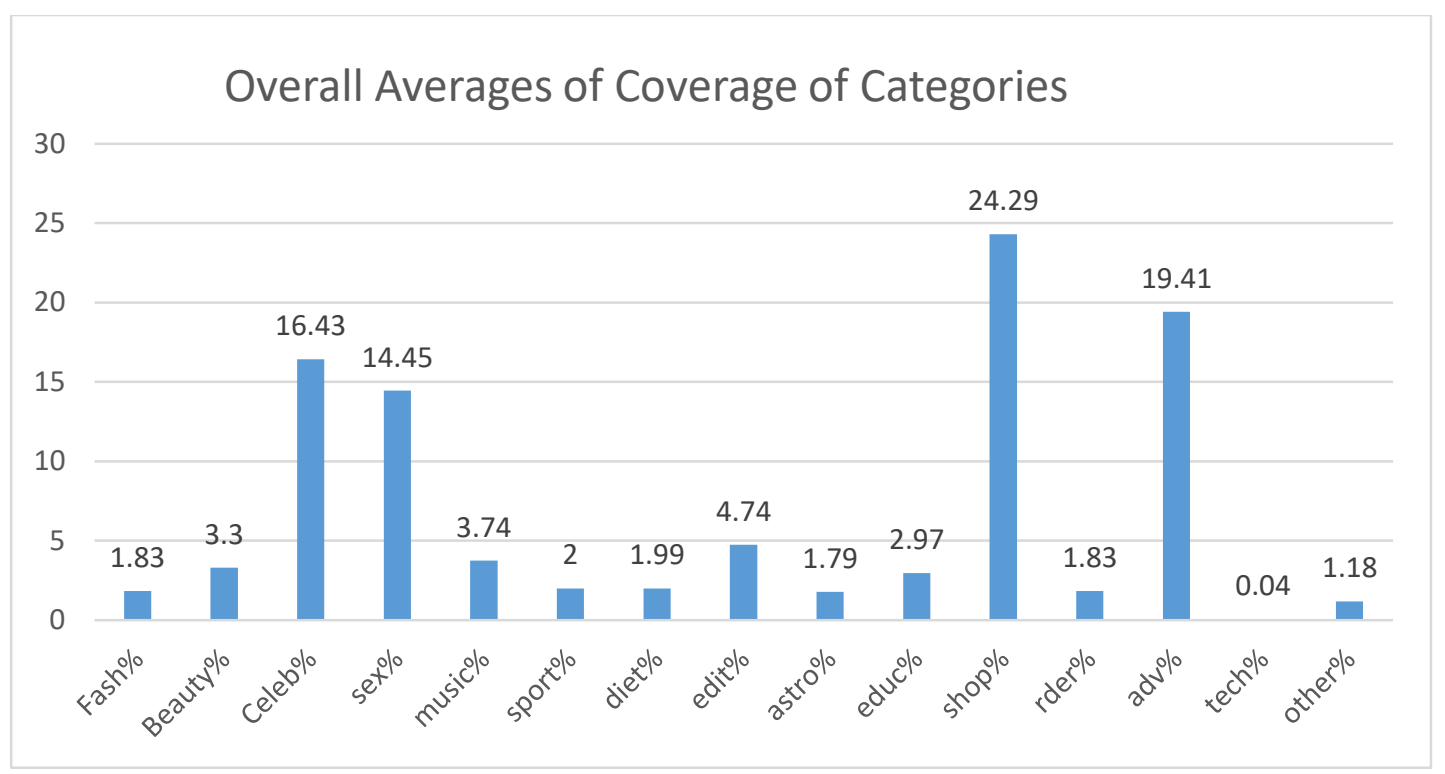

Figure 6: Overall Percentage of Categories in Magazines

The average figures indicate that sum of shopping tips and advertisements make up of more than $42 \%$ of both teen magazines $(44.25 \%$ for Hey Girl and $42.7 \%$ for Cosmo Girl). News, articles about and interviews with celebrities occupy almost $17 \%$, while articles, advice, questionnaires and stories about sex and relationships (mostly, tips and questionnaires on relationships with the opposite sex) make up for more than $14 \%$ of magazine contents, however this category occupies significantly more space in Hey Girl (over 17.5\%) compared to Cosmo Girl (11.1\%). Similarly, Cosmo Girl has a much higher coverage (5.7\%) of music articles and news compared to Hey Girl (1.8\%).

Generally, the contents category averages of 12 issues of each magazine are close to the general averages of the 24 issues.

For a comparison, Willemsen's (1998) findings on content analysis and linguistic analysis show that Fashion and beauty account for more than $25 \%$ of the pages of Yes, which is a girls' magazine. Hobbies, celebrities and stars, health also have important 
coverage with around $10 \%$ each. Shopping tips, reports, and love sex and relationships have about $7 \%$ coverage each. In Hey Girl and Cosmo Girl, there is almost twice as much coverage of the "love, sex and relationships" category. Coverage of celebrities is also higher (16\%) compared to Yes. The breakdown of shopping tips and advertisements given below in Tables 8 and 9 indicate that fashion and beauty are the two topics with highest coverage, as in Willemsen (1998).

In Webber (which is a Dutch boys' magazine), celebrities and stars account for more than $20 \%$ of the pages, followed by hobbies, which account for more than $12 \%$. Fashion comes third with about $9 \%$. Love, sex and relationships, and reports are close to $7 \%$ each. One interesting thing is, there is no romantic fiction section in Webber (Willemsen, 1998).

Advertisements are subcategorized further as:
a) Fashion advertisements (including clothing)
b) Accessories (earrings, necklaces, hairgrips, rings, etc.)
c) Books and magazines
d) Beauty products
e) Diet products, food and beverages
f) Technology products
g) Music - TV channels
h) Other

Shopping tips are subcategorized as:

a) Fashion 

b) Accessories
c) Beauty products
d) Mixed
e) Other

Celebrities are categorized as:
a) Fashion
b) Music
c) TV - Cinema
d) Mixed
e) Other

The following tables show how advertisements, shopping tips and celebrities' coverage is distributed among those subcategories.

Table 8: Distribution of advertisements among product categories

\begin{tabular}{|c|c|c|}
\hline $\begin{array}{c}\text { Advertisement } \\
\text { category }\end{array}$ & $\begin{array}{c}\text { \% in } \\
\text { advertisements }\end{array}$ & \% in all pages \\
\hline Fashion & 29.3 & $\mathbf{5 . 6 9}$ \\
\hline Accessories & 8.0 & $\mathbf{1 . 5 5}$ \\
\hline Books and magazines & 17.3 & $\mathbf{3 . 3 5}$ \\
\hline Beauty products & 16.9 & $\mathbf{3 . 2 9}$ \\
\hline Diet and food & 5.8 & $\mathbf{1 . 1 3}$ \\
\hline Technology & 2.5 & $\mathbf{0 . 4 9}$ \\
\hline Music, TV & 6.2 & $\mathbf{1 . 2 0}$ \\
\hline Other & 14.0 & $\mathbf{2 . 7 1}$ \\
\hline TOTAL & $\mathbf{1 0 0 . 0}$ & $\mathbf{1 9 . 4 1}$ \\
\hline
\end{tabular}

Table 8 indicates that almost one third of advertisements in girls' magazines are for fashion products. Books and magazines and beauty products are the next two most frequent and they occupy about $17 \%$ of all advertisements. Fashion products, beauty 
products and accessories constitute $54.2 \%$ of all advertisements. Figure 7 outlines the overall percentage distribution of advertisements to sub-categories.

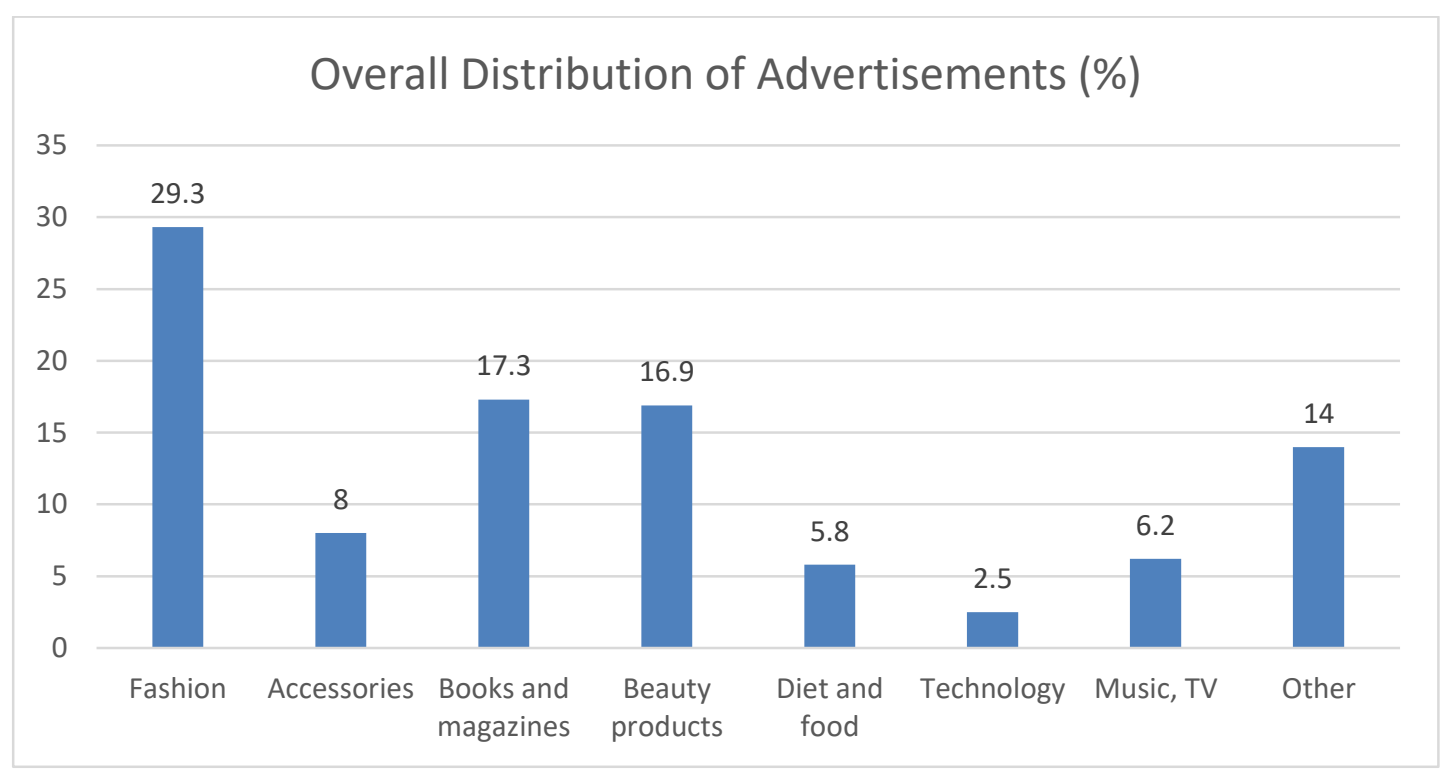

Figure 7: Overall Percentage of Advertisements with Respect to Categories

Table 9 : Distribution of shopping tips

\begin{tabular}{|c|c|c|}
\hline $\begin{array}{c}\text { Shopping Tip } \\
\text { category }\end{array}$ & $\begin{array}{c}\text { \% in shopping } \\
\text { tips }\end{array}$ & $\begin{array}{c}\text { \% in all } \\
\text { pages }\end{array}$ \\
\hline Fashion & 38.5 & $\mathbf{9 . 3 7}$ \\
\hline Accessories & 4.2 & $\mathbf{1 . 0 1}$ \\
\hline Beauty & 29.6 & $\mathbf{7 . 2 2}$ \\
\hline Mixed & 19.4 & $\mathbf{4 . 7 0}$ \\
\hline Other & 8.3 & $\mathbf{1 . 9 9}$ \\
\hline TOTAL & $\mathbf{1 0 0 . 0}$ & $\mathbf{2 4 . 2 9}$ \\
\hline
\end{tabular}

Table 9 shows that shopping tips on fashion products constitute almost $40 \%$ of all the tips in girls' magazines. Next most frequent shopping tips category is beauty products with almost $30 \%$. Fashion products and beauty products appear in $68.3 \%$ of all shopping tips. It should be noted that, mixed fashion tips also mostly include these two categories. So, it can be concluded that fashion products and beauty products constitute 
almost $75 \%$ of all shopping tips given in girls' magazines. Figure 8 shows the overall distribution of shopping tips to sub-categories.

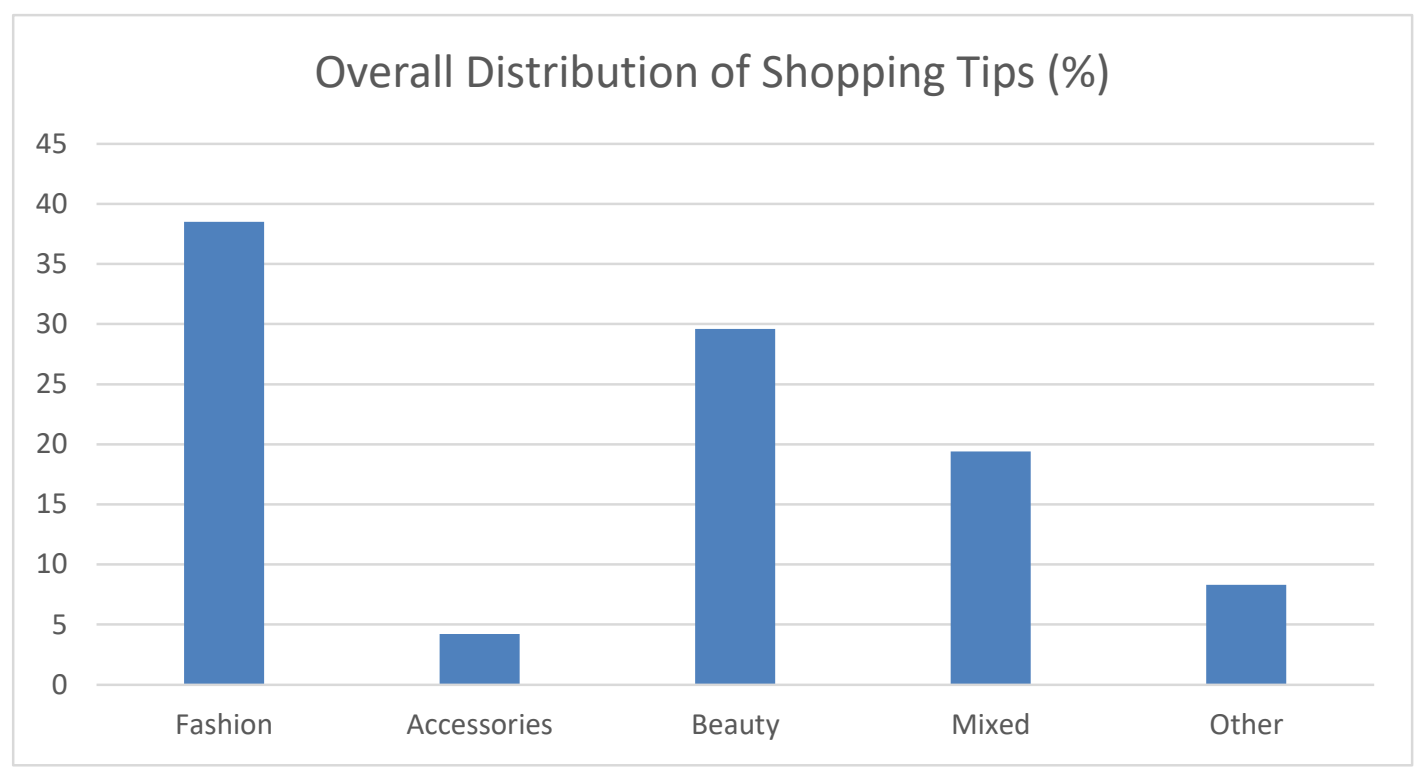

Figure 8: Overall Distribution of Shopping Tips

Table 10 : Distribution of celebrities among celebrity categories

\begin{tabular}{|c|c|c|}
\hline Celebrity category & $\begin{array}{c}\text { \% in } \\
\text { Celebrities }\end{array}$ & $\begin{array}{c}\text { \% in all } \\
\text { pages }\end{array}$ \\
\hline Fashion & 10.5 & $\mathbf{1 . 7 2}$ \\
\hline Music & 40.7 & $\mathbf{6 . 7 0}$ \\
\hline TV Stars & 29.1 & $\mathbf{4 . 7 8}$ \\
\hline Mixed & 7.9 & $\mathbf{1 . 2 9}$ \\
\hline Other & 11.8 & $\mathbf{1 . 9 4}$ \\
\hline TOTAL & $\mathbf{1 0 0 . 0}$ & $\mathbf{1 6 . 4 3}$ \\
\hline
\end{tabular}

Table 10 indicates that more than $40 \%$ of celebrities that appear in girls' magazines are singers or music bands' members. TV stars appear in about $30 \%$ of news and interviews with celebrities on various issues, mostly about their personal and professional lives. Fashion celebrities constitute only slightly more than $10 \%$ of celebrity appearances. Figure 9 gives the overall distribution of celebrities to subcategories. 


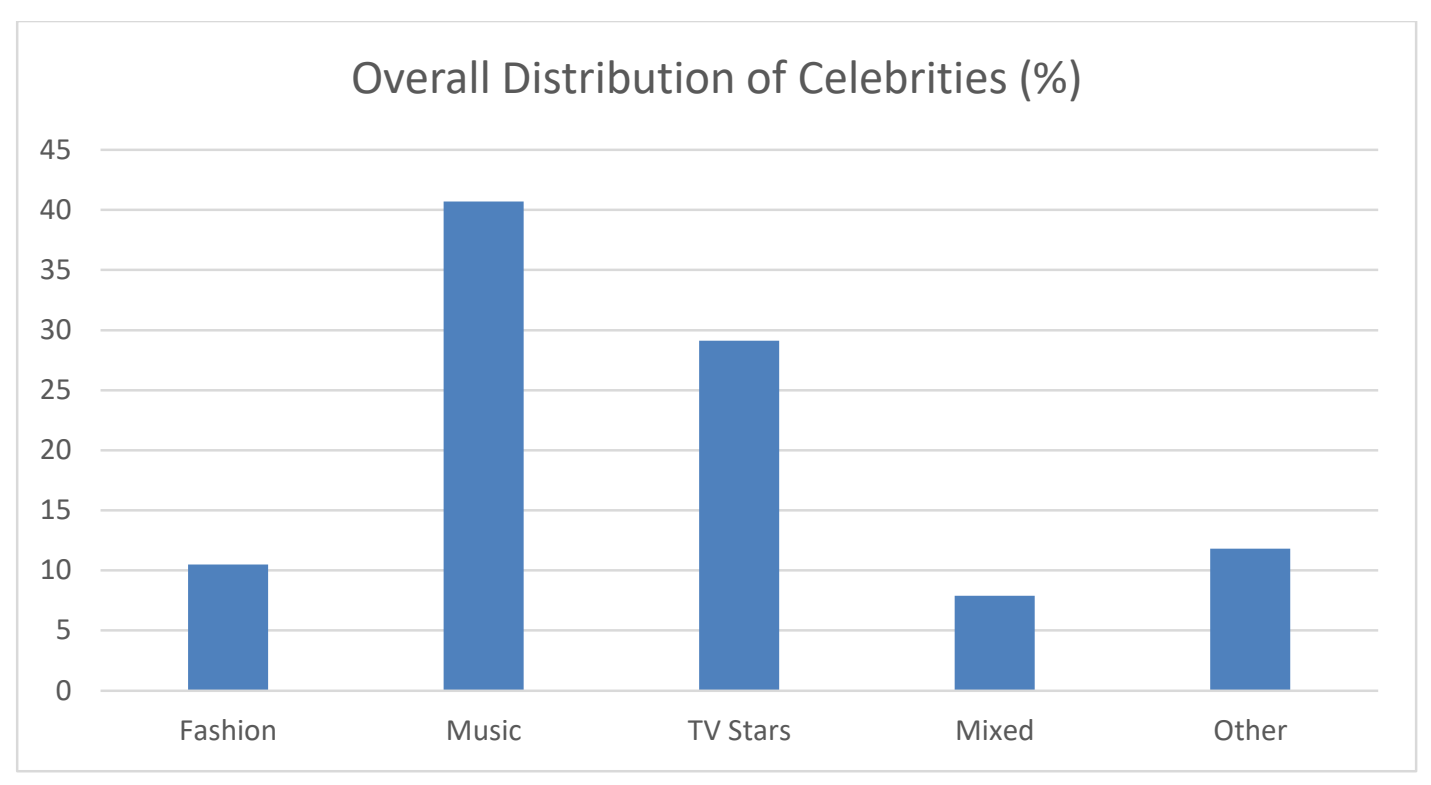

Figure 9: Overall Distribution of Celebrities

When the distribution of advertisements and shopping tips into subcategories presented in Tables 8 and 9 and the distribution into main categories outlined in Table 7 are combined, the coverage given to fashion and beauty products, considering both articles and pictorial content (in terms of advertisements and shopping tips) can be calculated as follows:

Total coverage of fashion products and accessories $\%=$

[fashion pages percentage (main) $]+[$ fashion + accessories total (advertisements) $]+$ [fashion + accessories total (shopping tips) $] \%$

$1.83+[5.69+1.55]+[9.37+1.01]=1.83+7.24+10.38=19.45 \%$

Total coverage of beauty products $\%=$

[beauty percentage (main) $]+[$ beauty products total (advertisements) $]+[$ beauty total (shopping tips) $]=3.30+3.29+7.22=13.81 \%$ 
So, adding these two terms, almost one third of girls' magazine contents (33.26\%) is devoted to fashion and beauty topics, mostly in pictorial form, in advertisements and shopping tips. This shows, teen magazines give a high coverage of fashion and beauty products.

\subsubsection{Content Analysis of Teen Magazine Covers}

In this section, results of the content analysis study on cover girls appearing on 24 teen magazine cover pages, 12 Cosmo Girl and 12 Hey Girl issues selected, from 2007 to 2010 are going to be discussed. The following attributes of cover girls are considered in this content analysis:
a) Hair color
b) Color of eyes
c) Profession (cinema, music, TV, or fashion celebrity)
d) Sex (male or female)

The results are outlined in tables 11 and 12 below. The names of cover girls/celebrities are also listed. 
Table 11 : Content analysis results of Cosmo Girl covers

\begin{tabular}{|c|c|c|c|c|c|}
\hline $\begin{array}{c}\text { Cosmo } \\
\text { Girl Issue }\end{array}$ & Hair Color & Eye Color & Celebrity & Profession & Sex \\
\hline $2007-01$ & Blonde hair & Hazel & $\begin{array}{c}\text { Jessica } \\
\text { Simpson }\end{array}$ & Cinema & $\mathrm{W}$ \\
\hline 2007-09 & Blonde hair & Blue & Fergie & Music & $\mathrm{W}$ \\
\hline $2007-11$ & Blonde hair & Brown & $\begin{array}{l}\text { Ashley } \\
\text { Tisdale }\end{array}$ & Cinema & $\mathrm{W}$ \\
\hline $2008-03$ & Blonde hair & Blue & Avril Lavigne & Music & $\mathrm{W}$ \\
\hline $2008-06$ & Brunette & Hazel & $\begin{array}{c}\text { Kelly } \\
\text { Clarkson }\end{array}$ & Music & $\mathrm{W}$ \\
\hline 2008-09 & Brunette & Blue & Hilary Duff & Cinema & $\mathrm{W}$ \\
\hline $2009-02$ & Brunette & Hazel & Lily Allen & Music & $\mathrm{W}$ \\
\hline 2009-02 & Blonde & Blue & $\begin{array}{c}\text { Taylor } \\
\text { Momsen }\end{array}$ & Cinema & $\mathrm{W}$ \\
\hline 2009-05 & Brunette & Blue & $\begin{array}{l}\text { Kristen } \\
\text { Stewart }\end{array}$ & Cinema & $\mathrm{W}$ \\
\hline $2010-01$ & Black & Blue & Sebnem Ferah & Music & $\mathrm{W}$ \\
\hline $2010-04$ & $\begin{array}{c}\text { Blonde, } \\
\text { Black, } \\
\text { Brunette }\end{array}$ & Brown & $\begin{array}{l}\text { Hepsi (Music } \\
\text { group, } 3 \text { girls) }\end{array}$ & Music & $\mathrm{W}$ \\
\hline $2010-12$ & Brunette & Blue & Emre Aydin & Music & $\mathrm{M}$ \\
\hline
\end{tabular}


Table 12: Content analysis results of Hey Girl covers

\begin{tabular}{|c|c|c|c|c|c|}
\hline $\begin{array}{l}\text { Issue of } \\
\text { Hey } \\
\text { Girl }\end{array}$ & Hair Color & Eye Color & Celebrity & Profession & Sex \\
\hline $2007-01$ & Brunette & Brown & Keremcem & Music & $\mathrm{M}$ \\
\hline $2007-09$ & Brunette & Blue & Masha & Model & $\mathrm{W}$ \\
\hline $2007-11$ & $\begin{array}{l}\text { Brunette, } \\
\text { Brunette }\end{array}$ & $\begin{array}{l}\text { Blue, } \\
\text { Green }\end{array}$ & $\begin{array}{l}\text { Pelin\& } \\
\text { Ibrahim }\end{array}$ & TV Stars & $\mathrm{W}+\mathrm{M}$ \\
\hline $2008-03$ & Blonde & Blue & No name & Model & $\mathrm{W}$ \\
\hline $2008-06$ & Brunette & Blue & $\begin{array}{l}\text { Pelin } \\
\text { Karahan }\end{array}$ & TV star & $\mathrm{W}$ \\
\hline $2008-09$ & Brunette & Brown & Ozge Kucuk & $\begin{array}{l}\text { (Molped \&HG cover } \\
\text { girl contest winner) }\end{array}$ & $\mathrm{W}$ \\
\hline $2009-02$ & $\begin{array}{l}\text { Brunette, } \\
\text { Blonde }\end{array}$ & $\begin{array}{l}\text { Brown, } \\
\text { Blue }\end{array}$ & $\begin{array}{l}\text { Keremcem - } \\
\text { K. Eylul } \\
\text { Akgol }\end{array}$ & $\begin{array}{l}\text { Music } \\
\text { HG reader }\end{array}$ & $\mathrm{W}+\mathrm{M}$ \\
\hline 2009-05 & Brunette & Blue & Sonya & Model & W \\
\hline 2009-08 & Brunette & Green & $\begin{array}{l}\text { Robert } \\
\text { Pattinson }\end{array}$ & Cinema & $\mathrm{M}$ \\
\hline $2010-01$ & Brunette & Hazel & $\begin{array}{l}\text { Taylor } \\
\text { Lautner }\end{array}$ & Cinema & $\mathrm{M}$ \\
\hline $2010-04$ & Brunette & Brown & $\begin{array}{l}\text { Justin } \\
\text { Bieber }\end{array}$ & Music & $\mathrm{M}$ \\
\hline $2010-12$ & Black & Brown & $\begin{array}{l}\text { Selena } \\
\text { Gomez }\end{array}$ & Cinema & $\mathrm{W}$ \\
\hline
\end{tabular}

\subsubsection{Cosmo Girl Covers}

Table 11 indicates that out of the 12 Cosmo Girl covers analyzed, 5 celebrities appearing alone are blonde and 5 are brunettes. One celebrity has dark hair which can be called black. On one cover, the famous Turkish young music group appears, the members of the group have blonde, brunette and black hair, all having brown eyes. Only one member of the group has a dark tan color. 
When the eye colors are considered, 7 celebrities have blue eyes, 3 celebrities have hazel eyes, and one has brown eyes. None of the brunettes have brown eyes. All the celebrities appearing alone have a white tan color.

Cosmo Girl has only one cover with a male celebrity, Emre Aydin, a Turkish singer on in 2010/02 issue. The celebrities appearing in 2007, 2008 and 2009 issues - in total 9 -, are all international celebrities. Those appearing in 2010 issues are Turkish celebrities. This may show an editorial policy change.

\subsubsection{Hey Girl Covers}

Table 12 indicates that among the celebrities appearing on Hey Girl covers, 3 are popular music stars, 3 are cinema stars, 3 are fashion models, 3 are TV stars, one is a magazine reader and one is a cover girl contest winner. Two TV stars casted in the “Kavak Yelleri” Turkish TV series popular among teenagers, Pelin and Ibrahim appear together in the 2008-06 issue, and a male music celebrity, Keremcem, appears with a magazine reader in the 2009-02 issue.

There are 11 brunettes, 2 blondes and one cover girl with black hair. The distribution of eye colors is 6 blue, 5 brown, 2 green and 1 hazel.

There are 7 international celebrities and 5 Turkish celebrities on the covers of Hey Girl issues analyzed.

On 4 of the covers, there are male celebrities and on 6 of the covers there are female celebrities. In two issues, where a pair of male and females appear, the pairs have posed embracing each other. 
Hey Girl magazine has casted its readers in two of the issues. On the 2008-09 issue cover, the winner of a cover girl contest organized by the Hey Girl magazine and Molped company, Ozge Kucuk appears. On the 2009-02 cover, a magazine reader who is a fan of the popular Turkish male singer Keremcem appears together with Keremcem.

Tables 11 and 12 show that blonde and brunette hair, and hazel and blue eyes are quite dominant in magazine covers and these physical properties are promoted as requirements for "ideal beauty".

\subsubsection{Comparison of Cosmo Girl and Hey Girl covers}

In the sample analyzed, most of the celebrities appearing on Cosmo Girl covers are blonde, while most of the celebrities appearing on Hey Girl covers are brunettes. Those celebrities appearing on Cosmo Girl covers mostly have blue eyes (7). Cosmo Girl covers have only one celebrity with brown eyes, while Hey Girl has casted 4 celebrities which have brown eye color. Hey Girl has also casted more celebrities with blue, green and hazel eyes (9) than those with brown eyes (5).

In both magazines, international celebrities appear most, although Hey Girl has casted more Turkish celebrities on its covers. Hey Girl has casted two magazine readers on its covers while Cosmo Girl has not done this.

In both magazines, celebrities appearing on covers have a white tan color, with only one exception, one music band member has a dark tan color on 2010-04 issue of Cosmo Girl. 
Considering all the 24 covers, there are 16 international celebrities and 8 Turkish celebrities. Although Hey Girl casted more Turkish celebrities compared to Cosmo Girl, its covers still contain more international celebrities. It has been reported earlier that Cosmo Girl is owned by the international media giant Hearst Corporation, but Hey Girl is a Turkish publication. These results shows that foreign celebrities dominate covers of teen magazines published in Turkey, and covers are devoted to celebrities mostly in line with the western ideal beauty standard of white, thin women with blue, green or hazel eyes. Even when Hey Girl's cover girls with darker hair and brown eyes are considered, their thinness, faces, noses and eyes and their dominantly white skin color fit the western beauty standards. This result is something that requires a discussion, and may be considered as one indicator of the already cultivated Western beauty standard in the Turkish society.

\subsubsection{Comparison of Cosmo Girl-Turkey and Seventeen-USA Magazines}

The Turkish Cosmo Girl magazine is owned by the Turkish media group Turkuvaz Gazete ve Dergi Basim A.S. However, it is also indicated that the name and publication rights belong to Hearst Corporation.

The Hearst Corporation publishes various teenager magazines in different countries. In Holland, the Czech Republic, China, Indonesia, and Hong Kong, the name of the magazine is Cosmo Girl, as in Turkey. It is published with the name Seventeen in the US, as well as in Argentina, Chile, Colombia, Ecuador, Venezuela, Malaysia, Mexico, Singapore, South Africa, and Thailand.

The information given at the web site of Seventeen magazine indicates that the first teenager magazine of Hearst Group was Cosmo Girl which had its first issue appearing 
in 1999. After the purchase of Seventeen magazine, which was published since 1944, by Hearst Corporation in 2003, for a short while, both magazines were published by Hearst, but after 2008, Cosmo Girl's US edition was closed down and only Seventeen continued to be published. For reasons unclear to us, the media giant Hearst Corporation has continued to publish some of its international editions under the title "Cosmo Girl", like in Turkey. It should be noted that, the Seventeen magazine was also published in Turkey for a short while, but it was quickly discontinued ${ }^{7}$.

The web site of the Seventeen magazine publihed in $\mathrm{UK}^{8}$ has the following mottoes: Seventeen Magazine is your handbook to life! Full of great fashion tips that keep you ahead of the trends... the hottest makeup, the best products for beautiful skin, must have jeans, the best shoes, belts \& bags, and those great little dresses that keep you looking your best at school, parties... or just about anywhere! Get the latest scoop on celebrities, music, movies and more. Plus, catch up on the guy scene every month with Seventeen's Guy Talk.

Looking at some of the articles published in Cosmo Girl magazine, the researcher suspected that they may be translated from the original US edition. Accordingly, the September 2010 issue of American Seventeen magazine and the October 2010 issue of Turkish Cosmo Girl magazine are compared to find out similarities and differences in contents. It is observed that some of the contents of Cosmo Girl are taken from Seventeen.

\footnotetext{
7 http://en.wikipedia.org/wiki/Cosmogirl , http://en.wikipedia.org/wiki/Seventeen_\%28magazine\%29

8 http://www.americanmagazines.co.uk/seventeen-magazine-subscription.html
} 
The first observation is that, the number of pages is quite different in the two magazines. Seventeen is 228 pages, while Cosmo Girl is only 100 pages. Seventeen is sold for 2.99 US dollars. Cosmo Girl is sold for 5 Turkish Liras in Turkey (which was approximately 3.5 US Dollars at that time) and for 6 Turkish Liras in Northern Cyprus (which was approximately 4 US Dollars). The cover photographs are exactly the same in both issues, featuring celebrity singer Katy Perry.

In its introductory pages, the contents of Seventeen are categorized as Fashion, Beauty, Health, Love Life, Your Life and Others by the magazine editors. On the other hand, the contents of Cosmo Girl are categorized as Celebrity News, Trend Alarm, Girl to Girl, Body and Soul, My Man, Zoom, and Others.

When the contents are compared, it has been found out that 15 pages of Cosmo Girl are directly taken from Seventeen after translation to Turkish. For example, the section called "Choose a Unique Date Spot!" in Seventeen appears with the same wording in Cosmo Girl under the heading "Benzersiz Flört Mekanları", which means exactly the same thing in Turkish. In the Turkish version, the comments at the bottom of every subsection are direct translations of the comments in Seventeen, and an impression is given as if the readers' letters are coming from Turkish readers. The signatures of readers are changed, but ages are the same. For example, one comment signed "Alexandra, 17, New Orleans" appears in Turkish Cosmo Girl with the same wording, but with signature "Ayça, 17, Istanbul” (Cosmo Girl, October 2010, p. 92 ; Seventeen, September 2010, p. 216). 
Also there are some problems detected with regards to the translation from English to Turkish. For example, in the US, the term "art museum" is used to indicate a location where art work such as paintings and sculpture are exhibited, in Turkish, there is no such term. The generic term "museum" is used instead for all types of locations exhibiting something. There can be "museums" where art work is exhibited, or there can be "museums" where historical findings are exhibited.

The topics related to sexuality appearing in Seventeen are not used at all in Cosmo Girl. In the interview with the cover girl Katy Perry, she says "I think it is sexier not to give it all away in one night". This sentence has been totally omitted in the same interview in Cosmo Girl (Seventeen, p. 193, Cosmo Girl, p. 69). Also, it has been observed that there are tampon advertisements (p. 97, p. 101) in Seventeen, but in my content analysis on various issues of the Cosmo Girl magazine, I never came across with a tampon advertisement. The reason for this is due to differences in culture. In the Turkish society, virginity of girls before marriage is very important. Since a virgin cannot use tampon, and companies which produce these items know that they cannot sell tampon products to girls, these advertisements do not appear in girls' magazines.

Considering the observations on the different coverage of sexual issues in the two magazines, it can be concluded that Cosmo Girl puts more emphasis on romantic relationships, and it omits some topics on sexual relations of girls with opposite sex, thereby trying to cover contents more acceptable by the sexually conservative Turkish society. 


\subsubsection{General Remarks on Magazine Contents}

In this section, some interesting coverage in the two magazines on different issues which are subjects of study in this study will be listed.

\subsubsection{Beauty}

In September 2008 issue of Hey Girl, on pages 86-87 (Appendix C), there is a title "Techniques to Mow Grass (Çim Biçme Yöntemleri)". The article starts with the sentence in upside-down format besides a pair of long legs of a girl with a mini skirt and high heel summer shoes: "don't think that the summer is over, even if they grow this is not a problem. To be a clean girl inside and outside is very easy. For this, you need to spend a small amount of time and power." In the article, the advantages and disadvantages of laser and laser with needle type epilation techniques and creams to get rid of body hair are mentioned. For laser and laser needle type epilation, the phone number and web site addresses of seven different centers are listed. On the right hand side of the page, brands and prices of hair reducing-removing cream, face serum and epilator are given with pictures. At the end of the article, two more suggestions are mentioned as "shaving and stick and remove epilating wax" and girls are asked to visit the web pages of the magazine for information on these two techniques.

In June 2008 Hey Girl, on p. 46, there is an article titled "Get the Tactics from Pelin", listing some beauty tips from a TV celebrity Pelin who also appears as the cover girl of that issue. She mentions that she likes long and flat hair. She used to dye her hair but she now prefers her natural color. She uses separate hair shampoo and conditioner and she goes to a hair care center once a month. She uses hairpins with different colors. Although she says she does not like heavy make-up, her photo on the page actually shows she did heavy make-up for the photo shooting. She mentions her brand choice 
(Mac) for cosmetic products. When she gets back home, she performs a daily cleaning and uses a moisturizer suggested by her doctor. She uses baby oil after every bath. She explains she uses hand cream which also is good for care taking of nails. She likes "French-style" nail polish.

\subsubsection{Conflicting or Mixed Messages}

There are some conflicting messages in these magazines. For example, on the cover of 2010-April issue of Cosmo Girl, it says "Boys are not looking at your appearance", but on the cover of its 2007-January issue it says "your nickname should not be big boobs". This is a reminder of Behçetoğulları's (2008) remarks that women construct a conflicting control on their body, simultaneously ordering herself to do and not to do, be free but not too much, be seductive but also be like a mother. This type of mixed (negative/positive) messages are also reported by Fuller (2005) on her content analysis study on the Seventeen magazine.

Cosmo Girl magazine has been published with the slogan "Free Girls' Magazine" in its 2009 February issue. As the $14^{\text {th }}$ of February is the Valentine's Day, there is an article trying to console girls who have no boyfriends on page 44 . In both magazines, culturally acceptable man-woman relationships and the meaning of being female are reproduced. On page 52, there is a section called "Intelligent Girl". In this section, there is a title called "Surprise him with your intelligence" which suggests teenager girls to buy exceptional presents for the Valentine's Day to surprise their boyfriends. ("Buy him an exceptional present for the Valentine's Day so that his IQ will be like zero compared to yours, how about this?"). Also in this section, on pages 52 and 53, there are suggestions on what might be exceptional presents, together with their prices. The conclusion that can be derived from this section is that a teenager girl should learn 
how to buy exceptional presents in order to influence her boyfriend with her intelligence.

In Hey Girl's 2010-December issue, there is a section on page 51 titled "In order not to be late, not to be sorry and not miss the life, do these things before your $18^{\text {th }}$ birthday comes". There is a list of 18 items that should be done. The first item is "learn how to cook". Among the other items, there are "wear high heel shoes", "learn how to make make-up" and "live some summer loves". These items mostly concentrate on women's traditional role of serving men for food and pleasing them with their physical appearance.

\section{Messages about Appearance}

There are some messages in these magazines about the preferred appearance of young girls. In the same issue, on page 38 , under the title "Trend alarm", it says "it is not sufficient to make make-up, you have to be determined to be beautiful otherwise your beauty will lose its effect." On page 40, information is given on various hair styles under the heading "fast and flirtous hair styles" (flirtous is a made-up word, meaning flirting, and a similar word, "flörtöz" which is not Turkish, is also made-up for). On pages 66 and 67, under the heading "The best of you until now", some exercises are suggested to "shape your legs", "work out your stomach", "make your hips tighter", "strengthen your arms" and "make your shoulders explicit" .

Stereotypical looks for women/girls appear in magazines, even in advertisements such as Hey Girl March 2008 issue pp. 6-7 which is an advertisement by Twist clothing company, using Barbie dolls, and the setting is the kitchen of the house (Appendix C). 


\section{Beauty Tips}

In Cosmo Girl's 2009-August issue, on page 78, under the title "Natural beauty", the following question is asked: "are you ready to get freshened and get beautiful from your hair to your make-up, without losing your natural appearance and using organic products?". On the accompanying page, page 79 , there are beauty products like mascara, foundation cream, lip polisher, blusher and powder, with their prices also listed.

\section{Celebrities}

On the cover of 2007-September Cosmo Girl issue, a quotation, "I can fall in love with one of my fans", from a Turkish male celebrity, Gokhan Ozen is given. On page 64 of Cosmo Girl's 2010-April issue, under the title "Be a fan but not fall in love", "Soul doctor Sait" is giving recommendations to girls who fall in love with celebrities not to suffer from disappointment.

\section{Healthy Nutrition}

In the 2010-January issue of Hey Girl, on pages 82 and 83, in the "keep your form" section, healthy nutrition tips are given under the title "You should not have kilograms of problems". On the following page, page 84, chocolate apple candy and apple pie recipes are given. On page 85 , under the title "try these", some fruit flavored candies, ice cream, hot chocolate and various cake products are advertised with a news format appearance. These are all conflicting messages.

\section{Fashion}

On one hand, tips on how to construct one's own accessories or t-shirts which are similar to the ones celebrities are wearing are given, on the other hand, in the same issue, there are shopping tips about 33 different accessories mentioning where and for how much they can be purchased. 


\section{Consumption}

In June 2008 issue of Hey Girl magazine, on p.90, under the title "Color Your Vanity Bag (Makyaj Çantanı Renklendir)" (Appendix C), there are recommendation for girls to visit perfume depots for cheaper products and to produce some home-made beauty products. Home-made products suggested are "Cauliflower Mask", "Peeling", "Tonic", "Hand Cream", and recipes are given for them using cauliflower, cucumber juice, rose juice, olive oil and the like.

In the same issue on the same page, there is a subtitle "Recycle (Geri Dönüştür)". Under this title, girls are advised to add olive oil to their eye lashes if they dried out, you can use the brush of your eye lash to comb your eye brows, you can use cotton sticks for ears to apply almost finished lipstick to your lips for economy. However, on the same page there are suggestions on how to buy beauty products from the Internet, and there are shooping tips for lipsticks, perfumes and eye shadows, with prices also mentioned.

In the same issue on page 88-89, there are titles: "Little Budget, Big Change" and "A New Closet". For the first title, there are suggestion like paint your own room, renew your bedroom linens and sheets by making use of beginning of summer campaigns, purchase furniture from stores where you can get modular products. For the second title, girls are advised to stay away from expensive brand products and they are advised that one can buy higher quality products cheaper by visiting local bazaars. They are also advised to look for discount sales or purchase clothes from small shops. However, on page 89 , there are shopping tips for assorted brand products which are not cheap 
making a whole outfit. In addition, girls are advised to check the web pages for a variety of clothes and shoes.

\subsubsection{Sexual Content in Teen Magazines}

In this section, sexual contents appearing in the 24 issues of Cosmo Girl and Hey Girl magazines analyzed in this study will be discussed issue by issue.

2007-January: In Cosmo Girl, there is an article titled "At which age should we practice sex" on page 81 . In Hey Girl, there are two sex related topics discussed. One is titled "If we go any further, will he consider me as a simple girl?", and the other is titled "Is masturbation dangerous?".

2007-September: In Cosmo Girl, on page 63 there is a so called "social advertisement" which claims when birth control pills are used regularly, they protect the girls and also prevent acne. On page 77, there is a section called "Girl to Girl" which has an article called "I didn't know that my boyfriend was gay". In Hey Girl, on pages 96 and 97 there is a section called "Time to get informed: Sexual Advise Line".

2007-November: In Cosmo Girl, on p. 95, there is a section on "Scratches in the genital area”. No sexual content was spotted in this issue of Hey Girl.

2008-March: No sexual content appears in this issue of both magazines.

2008-June: An article on page 83 in Cosmo Girl discusses age 18: "age 18 is the time when you desire all at once, becoming the biggest driver, thinking that you become super active sexually all of a sudden, and you can cope with this". Hey Girl has an 
article which discusses the worries of teenagers that they may be in their menstruation period during the prom night. The article advices girls to consult a doctor to find out whether they can use pills to postpone their menstruation period.

2008-September: There is no sexual content in Cosmo Girl. In Hey Girl, there is an article titled "Decode the cipher of his touches, if he is kissing you frequently".

2009-February: Cosmo Girl has two articles discussing the menstruation period, and one article on cervix cancer. There is no sexual content in Hey Girl.

2009-May: Cosmo Girl has two pages of "Orkid" (sanitary napkin) advertisements titled "The miracle I live on special days" on pages 28 and 29. It has an article on the menstruation period on page 97 . There is a section titled "What if your boyfriend wants to take you to his home in your graduation night" on page 72. Hey Girl has a "Kotex" advertisement titled "Sexual Hygiene", and a social advertisement on page 65 titled "Don't let your future slip away at an unexpected moment: Protected woman is conscious woman".

2009-August: Cosmo Girl has no sexual content. Hey Girl has an article on page 87 titled "Do not stay in the pool or at the seaside with a wet swimming suit, keep your genital area dry".

2010-January and 2010-April: There is no sexual content in these issues of both magazines. 
2010-December: There is no sexual content in Cosmo Girl. In Hey Girl, on pages 40 and 41 there is a section called "My Health Agenda". Item 11 in this section is titled "Get a gynecological examination" which states a quotation from celebrity Rihanna explaining she had a gynecological examination, and by using birth control pills she started taking after the examination, she can now cope with all her problems. She says she is even more comfortable in her outfits now. On page 51, there is a section titled "Do these before you are 18". The seventh suggestion is that girls should go to a gynecologist to find solutions for the pre-menstruation syndrome and to get information on birth control methods.

Among the sexual content appearing in the magazines, two instances appear in "social" advertisements related with birth control pills. In one article, sexual health is discussed. In various pad and panty-liner advertisements, information is given about the menstruation period. Apparently, this information is related with the product to be sold. The information appears in news format, and it is given by Molped, Orkid and Kotex companies. These companies hold a big share in this market in Turkey and North Cyprus.

\subsubsection{Consumption, Distribution and Prices of Goods and Products}

A study on teen magazines should include an analysis from consumption point of view. Results discussed below in our content analysis of popular teen magazines include the products promoted or advertised in two issues of Cosmo Girl, 2007-09, and 2009-02, and one issue of Hey Girl. It is shown that the total price of all goods and products advertised sums up to a very high value. In February 2009 issue of Cosmo Girl, 38,862 TL worth of products have appeared in shopping tips. One US dollar was worth 1.64 Turkish liras at that time, so this translates to a total of USD 23,706 worth of products. 
In December 2010 issues of Hey Girl (pp. 4-5) and Cosmo Girl (pp. 14-15) there is an advertisement of Is Bank about additional credit cards for youngsters (Appendix C). The title is: "A new way of making life easy for families: MaxiPara Genclik". The text of the advertisement on the first page is written for parents. It says if you want to keep track of the allowances you give to your child and have him/her learn about how to administer their personal budget, the MaxiPara Genclik card is just for you. Also included are a discussion on the ease and security of the use of this card, and the fact that parents can give pre-order for adding fixed amounts to the card at regular intervals.

On the second page, there is a huge font message for youngsters saying: if you are tired of asking for allowance, cut the advertisement on the previous page and stick it on the magazine your parents read. The previous page includes a cutting dashed line with a scissors symbol on the very right.

\subsubsection{Consumption Related Beauty and Fashion Messages}

In September 2007 issue of Cosmo Girl, on page 11, there is a diary for the month (Appendix C). The date format is American: 09/07. For everyday, there are suggestions for what to consume/purchase, from beuty products to food (ice cream, yoghurt drink, pasta). For day 10, there is a message for girls: "if your mother is complaining that her breasts are not tight, taje her to the nearest pharmacy and introduce her to the BeautyBreast cream." For day 23, there is a similar message: "your mother should not skip the night, let her use the Olay Complete Care moisturizer and she will wake-up as a younger person in the morning.

\subsubsection{Traditional and Feminist Messages in Advertisements}

Advertisements in all magazines taken into consideration for this study are analyzed to find the percentages of traditional and feminist messages. Advertisments concentrating on the outlook of models, male-female relationships and home related 
issues are considered to be traditional. Advertisements about self-development or political/world issues are considered to be feminist. Advertisements not falling into these two categories are considered to be neutral.

Out of 742 advertisements analyzed, $519(70 \%)$ were traditional, $213(28.6 \%)$ were neutral and only $10(1.4 \%)$ were feminist. The details are given in Table B5 in Appendix B.

\subsection{Survey Findings}

Firstly, some important findings from the questionnaire are given below, in the same order as in the questionnaire.

\subsubsection{Shopping from Supermarkets for the Family}

Table 13 : Shopping from supermarkets for the family

\begin{tabular}{|c|c|c|}
\hline Answer & $\begin{array}{c}\text { No. of } \\
\text { respondents }\end{array}$ & $\begin{array}{c}\text { \% of respondents } \\
(\mathbf{n = 1 5 6})\end{array}$ \\
\hline Yes & 120 & $\mathbf{7 6 . 9}$ \\
\hline No & 35 & $\mathbf{2 2 . 5}$ \\
\hline No answer & 1 & $\mathbf{0 . 6}$ \\
\hline TOTAL & $\mathbf{1 5 6}$ & $\mathbf{1 0 0 . 0}$ \\
\hline
\end{tabular}

Table 13. Shows that more than $75 \%$ of girls do supermarket food and beverage shopping for their families.

\subsubsection{Owning a Bank Card}


Table 14 : Ownership of personal bank card

\begin{tabular}{|c|c|c|}
\hline Answer & $\begin{array}{c}\text { No. of } \\
\text { respondents }\end{array}$ & $\begin{array}{c}\text { \% of respondents } \\
(\mathbf{n = 1 5 6})\end{array}$ \\
\hline Yes & 26 & $\mathbf{1 6 . 7}$ \\
\hline No & 129 & $\mathbf{8 2 . 7}$ \\
\hline No answer & 1 & $\mathbf{0 . 6}$ \\
\hline TOTAL & 156 & $\mathbf{1 0 0 . 0}$ \\
\hline
\end{tabular}

Table 14 indicates that a considerable percentage of teenage girls are owners of personal bank cards. Almost $17 \%$ of them have their personal bank cards. Since they are not 18 years old yet, owning a personal bank card linked to their parents' accounts is an important advantage to do shopping on their own. However, at the time of this study, only about one fifth of the girls had this opportunity.

\subsubsection{Mobile Phone Ownership}

Mobile phones have entered our lives at the end of $20^{\text {th }}$ Century, and they have become an important personal item for the whole society, as well as teenagers. For them, it is a matter of prestige to own a cellular phone. The seventh question was aimed at determining mobile phone ownership.

Table 15 : Do you have a personal mobile phone?

\begin{tabular}{|c|c|c|}
\hline Answer & $\begin{array}{c}\text { No. of } \\
\text { respondents }\end{array}$ & $\begin{array}{c}\text { \% of respondents } \\
(\mathbf{n}=\mathbf{1 5 6})\end{array}$ \\
\hline Yes & 142 & 91.1 \\
\hline No & 12 & 7.7 \\
\hline No answer & 2 & 1.2 \\
\hline TOTAL & 156 & $\mathbf{1 0 0 . 0}$ \\
\hline
\end{tabular}

Table 15 shows that $91 \%$ of the girls who filled the questionnaire own personal mobile phones. Although cellular phones (especially the new ones) are rather expensive items, it is important to note that more than $90 \%$ of girls own cellular phones. 
Table 16: Number of current phone

\begin{tabular}{|l|c|c|}
\hline Current phone is & No. of respondents & \% of respondents \\
\hline First & 19 & $\mathbf{1 3 . 4}$ \\
\hline Second & 32 & $\mathbf{2 2 . 5}$ \\
\hline Third & 41 & $\mathbf{2 8 . 9}$ \\
\hline Fourth & 28 & $\mathbf{1 9 . 7}$ \\
\hline Fifth or more & 22 & $\mathbf{1 5 . 5}$ \\
\hline TOTAL & $\mathbf{1 4 2}$ & $\mathbf{1 0 0 . 0}$ \\
\hline
\end{tabular}

Table 16 indicates that most of the mobile phone owners are changing phones very frequently. Answers to a follow-up question indicates that $36.5 \%$ of the respondents change their mobile phone every $10-12$ months and $15 \%$ of girls change their phones in less than 9 months. This is an indicator of the need of owning the most recent cellular phone for higher prestige among their peers. Also, owning a cellular phone means the teenager needs credit to be able to speak on the phone and to send SMS messages. Considering they have only limited weekly/monthly allowances, they spend an important portion of their allowances for buying cellular phone tokens and their families are asked for extra support for this.

\subsubsection{Internet Connection}

Table 17: Internet connection at home

\begin{tabular}{|c|c|c|}
\hline Answer & $\begin{array}{c}\text { No. of } \\
\text { respondents }\end{array}$ & $\begin{array}{c}\text { \% of respondents } \\
(\mathbf{n = 1 5 6})\end{array}$ \\
\hline Yes & 116 & $\mathbf{7 4 . 4}$ \\
\hline No & 39 & $\mathbf{2 5 . 0}$ \\
\hline No answer & 1 & $\mathbf{0 . 6}$ \\
\hline TOTAL & 156 & $\mathbf{1 0 0 . 0}$ \\
\hline
\end{tabular}

Table 17 shows that there were still many homes without an Internet connection in North Cyprus at the time of study. $25 \%$ of the respondents said they do not have an Internet connection at home. As the opportunity to get connected to the Internet from 
home increases, the girls can read teen magazines online easily, since most of the magazines now have web pages available on the Internet.

\subsubsection{Satellite Receiver and Satellite Music Channels Watched}

Question 12 of the questionnaire asked the girls whether they had a satellite TV receiver at their home. Table 18 shows that almost $95 \%$ of homes have satellite TV receivers. This is a much higher percentage than Internet connection ownership, summarized in Table 17. Having a satellite TV receiver at home means girls watch music channels frequently which show celebrities with heavy make-up representing the western beauty ideals, and which show commercials repeatedly, increasing the impact of mass media on consumption of items like clothing which appear on these channels.

Table 18: Satellite TV receiver ownership

\begin{tabular}{|c|c|c|}
\hline Answer & $\begin{array}{c}\text { No. of } \\
\text { respondents }\end{array}$ & $\begin{array}{c}\text { \% of respondents } \\
(\mathbf{n = 1 5 6})\end{array}$ \\
\hline Yes & 148 & $\mathbf{9 4 . 9}$ \\
\hline No & 5 & $\mathbf{3 . 2}$ \\
\hline No answer & 3 & $\mathbf{1 . 9}$ \\
\hline TOTAL & 156 & $\mathbf{1 0 0 . 0}$ \\
\hline
\end{tabular}

The next question asked the satellite TV music theme channel most watched by the girls. Girls were allowed to make more than one choice. A total of 231 choices were mentioned. Considering the total number of respondents, 156, this means that on the average one of every two girls mentioned two choices. The results are summarized below in Table 19. 
Table 19: Satellite TV music theme channels most watched

\begin{tabular}{|c|c|}
\hline $\begin{array}{c}\text { Music channel } \\
\text { most watched }\end{array}$ & $\begin{array}{c}\text { No. of } \\
\text { respondents }\end{array}$ \\
\hline MTV & 49 \\
\hline Kral TV & 40 \\
\hline VH1 & 7 \\
\hline Number1TV & 39 \\
\hline Power Turk & 57 \\
\hline Dream TV & 24 \\
\hline Others & 15 \\
\hline
\end{tabular}

Among the channels mentioned in the question, MTV and VH1 are international channels. The other channels are Turkish music TV channels. Dream TV channel is owned by the Dogan Media group which also owns the Hey Girl magazine. VH1 is not watched a lot, probably because of the fact that it plays nostalgia music from 1970 's, 1980's and 1990's very often. In addition to the channels listed in the question, 7 girls mentioned Viva and 3 girls mentioned MCM. Among the foreign channels, MTV got the most number of preferences. Among the Turkish music channels, Power Turk is the most popular one.

\subsubsection{Purchases with the Allowance}

Table 20 : Item purchased most with allowance

\begin{tabular}{|c|c|c|}
\hline Item Purchased & No. of respondents & $\begin{array}{c}\text { \% of } \\
\text { respondents } \\
(\mathbf{n = 1 5 6})\end{array}$ \\
\hline Food & 44 & $\mathbf{2 8 . 2}$ \\
\hline Clothes & 44 & $\mathbf{2 8 . 2}$ \\
\hline Accessories & 14 & $\mathbf{9 . 0}$ \\
\hline Beauty products & 8 & $\mathbf{5 . 1}$ \\
\hline Books & 3 & $\mathbf{1 . 9}$ \\
\hline Magazines & 8 & $\mathbf{5 . 1}$ \\
\hline Multiple answers & 19 & $\mathbf{1 2 . 2}$ \\
\hline Other & 16 & $\mathbf{1 0 . 3}$ \\
\hline TOTAL & $\mathbf{1 5 6}$ & $\mathbf{1 0 0 . 0}$ \\
\hline
\end{tabular}


When the girls were asked to indicate what they purchase most with their allowances, 28.2\% each said they mostly purchase food and clothes. $9.0 \%$ of girls mostly purchase accessories and $5.1 \%$ each are mostly buying beauty products and magazines with their allowances. This question was asked for a single answer, but some $12.2 \%$ of girls marked multiple answers. Among the multiple answers, food and clothes were again the top two items with 10 and 8 choices. Among those who selected some other item, 15 girls $(9.5 \%)$ are mostly purchasing phone tokens with their allowances. Although girls purchasing magazines most with their allowance is low (about 5\%), Table 28 in section 4.2.12 shows a very large majority of girls (almost 90\%) do buy magazines.

\subsubsection{Purchasing Plans for the Near Future}

When the girls were asked to indicate what they plan to buy in the near future, they had 7 items to select from, and in case they were planning to buy some other thing, they had the 'other' choice to select. The results showing their choices are given below in Table 21.

Table 21 : Item To Be Purchased In The Near Future

\begin{tabular}{|c|c|}
\hline Item Purchased & $\begin{array}{c}\text { No. of } \\
\text { respondents }\end{array}$ \\
\hline Cellular phone & 53 \\
\hline Ipod/MP3 Player & 16 \\
\hline Computer & 32 \\
\hline Clothes & $\mathbf{6 5}$ \\
\hline Beauty products & 17 \\
\hline Accessories & 22 \\
\hline Books & 27 \\
\hline Other & 21 \\
\hline
\end{tabular}

In this question, some girls marked more than one choice. A total of 253 choices were indicated. Among the choices, clothes appear to be the first, followed by cellular 
phone. Computer is the third choice. The total of choices made by girls for popular technological products is 101 , which is about $40 \%$ of all choices.

\subsubsection{Importance of Brand}

$55.1 \%$ of the girls think brand is important for them. The reasons of why they find using well-known brand products important are that they are high quality, dependable, and they last longer. Some of the girls said wearing brand products make them cool. $42.3 \%$ of the girls think brand is not important, most of those girls believe wearing brand products is unnecessary. $2.6 \%$ of girls did not answer this question.

\subsubsection{Body Mass Index}

Question 17 asked the girls to write down their height and their weight. Using the weight and height information given by the teenager girls, body mass index (BMI) was calculated for all 156 respondents with the formula BMI $=$ weight $/$ height $^{2}$. Cut-off points for various BMI categories are the internationally accepted values as given in (Cole et al., 2007).

Table 22: BMI values of respondents

\begin{tabular}{|c|c|c|}
\hline BMI & No. of respondents & $\begin{array}{c}\text { Percentile } \\
(\mathbf{n = 1 5 6})\end{array}$ \\
\hline $\begin{array}{c}\text { BMI }<\text { 18.5 } \\
\text { (underweight) }\end{array}$ & 38 & $\mathbf{2 4 . 4}$ \\
\hline $\begin{array}{c}\mathbf{1 8 . 5}<=\text { BMI }<24.9 \\
\text { (normal) }\end{array}$ & 106 & $\mathbf{6 7 . 9}$ \\
\hline $\begin{array}{c}25<=\text { BMI }<29.9 \\
\text { (overweight) }\end{array}$ & 11 & $\mathbf{7 . 1}$ \\
\hline $\begin{array}{c}\text { BMI }>=30 \\
\text { (obese) }\end{array}$ & 1 & $\mathbf{0 . 6}$ \\
\hline TOTAL & $\mathbf{1 5 6}$ & $\mathbf{1 0 0 . 0}$ \\
\hline
\end{tabular}

The data given in Table 22 shows that more than two thirds of the girls $(67.9 \%)$ that took part in the questionnaire study are in the normal weight category. Almost one 
quarter of them (24.4\%) are underweight. The total of girls who are normal weight or underweight is $92.3 \%$. Only $7.1 \%$ of girls are overweight, and one girl is obese.

\subsubsection{Dieting}

In questions 18, 19 and 20, girls were asked questions related to dieting. Firstly, they were asked whether they went on a diet in the past. The next question asked whether they are currently on a diet. The third question asked whether they plan to go on a diet in the near future. The results are given below in Tables 23, 24 and 25.

Table 23 : Diet Experience

\begin{tabular}{|c|c|c|}
\hline Answer & $\begin{array}{c}\text { No. of } \\
\text { respondents }\end{array}$ & $\begin{array}{c}\text { \% of respondents } \\
(\mathbf{n = 1 5 6})\end{array}$ \\
\hline Yes & 66 & 42.3 \\
\hline No & 90 & $\mathbf{5 7 . 7}$ \\
\hline No answer & 0 & $\mathbf{0}$ \\
\hline TOTAL & 156 & $\mathbf{1 0 0 . 0}$ \\
\hline
\end{tabular}

Table 24 : Currently on diet?

\begin{tabular}{|c|c|c|}
\hline Answer & $\begin{array}{c}\text { No. of } \\
\text { respondents }\end{array}$ & $\begin{array}{c}\text { \% of respondents } \\
(\mathbf{n = 1 5 6})\end{array}$ \\
\hline Yes & 34 & $\mathbf{2 1 . 8}$ \\
\hline No & 121 & $\mathbf{7 7 . 6}$ \\
\hline No answer & 1 & $\mathbf{0 . 6}$ \\
\hline TOTAL & 156 & $\mathbf{1 0 0 . 0}$ \\
\hline
\end{tabular}

Table 25 : Intention to hold a diet in the near future

\begin{tabular}{|c|c|c|}
\hline Answer & $\begin{array}{c}\text { No. of } \\
\text { respondents }\end{array}$ & $\begin{array}{c}\text { \% of respondents } \\
(\mathbf{n = 1 5 6})\end{array}$ \\
\hline Yes & 76 & $\mathbf{4 8 . 7}$ \\
\hline No & 79 & $\mathbf{5 0 . 6}$ \\
\hline No answer & 1 & $\mathbf{0 . 6}$ \\
\hline TOTAL & 156 & $\mathbf{1 0 0 . 0}$ \\
\hline
\end{tabular}

The results show that 42.3 percent of the girls were on a diet at least once in the past. 21.8 percent of girls said they are currently on a diet and 48.7 percent (almost half) of 
the girls said they are planning to go on a diet in the near future. According to the Body Mass Index (Cole, T.J. et al., 2007) values for girls given above in Table 22, actually only eleven girls are overweight, and one girl is obese, while 67.9 percent have normal weight, and 24.4 are underweight. It is quite notable that almost half of the girls, although they are mostly not overweight, plan to go on a diet. This shows almost half of the girls do not find themselves thin enough.

\subsubsection{The Most Beautiful Eye and Hair Colors}

Questions 21 and 22 asked the respondents which hair and eye colors show a girl "most beautiful". The results are given below in Tables 26 and 27 .

Table 26: The most beautiful hair color

\begin{tabular}{|c|c|c|}
\hline Color & $\begin{array}{c}\text { No. of } \\
\text { respondents }\end{array}$ & $\begin{array}{c}\text { \% of } \\
\text { respondents } \\
(\mathbf{n = 1 5 6})\end{array}$ \\
\hline Own natural color & 114 & $\mathbf{7 3 . 1}$ \\
\hline Blonde & 13 & $\mathbf{8 . 3}$ \\
\hline Brunette & 7 & $\mathbf{4 . 5}$ \\
\hline Black & 12 & $\mathbf{7 . 7}$ \\
\hline Red & 9 & $\mathbf{5 . 8}$ \\
\hline Other & 1 & $\mathbf{0 . 6}$ \\
\hline TOTAL & $\mathbf{1 5 6}$ & $\mathbf{1 0 0 . 0}$ \\
\hline
\end{tabular}

Table 27: The most beautiful eye color

\begin{tabular}{|c|c|c|}
\hline Color & $\begin{array}{c}\text { No. of } \\
\text { respondents }\end{array}$ & $\begin{array}{c}\text { \% of } \\
\text { respondents } \\
(\mathbf{n = 1 5 6 )}\end{array}$ \\
\hline Own natural color & 90 & $\mathbf{5 7 . 7}$ \\
\hline Green & 37 & $\mathbf{2 3 . 7}$ \\
\hline Blue & 24 & $\mathbf{1 5 . 4}$ \\
\hline Brown & 3 & $\mathbf{1 . 9}$ \\
\hline Other & 2 & $\mathbf{1 . 3}$ \\
\hline TOTAL & $\mathbf{1 5 6}$ & $\mathbf{1 0 0 . 0}$ \\
\hline
\end{tabular}


$73 \%$ of the girls seem to be more happy and comfortable with the color of their hair and they indicated that their favorite hair color is their own natural hair color. On the other hand, it is interesting to note that $14.1 \%$ of girls selected blonde or red as the color which shows a girl most beautiful, which are not at all common among Turkish Cypriots. Focus group study results are different and favorite hair colors are blonde and brunette, as indicated in section 4.3.

Similar to the hair colors, more than half of the girls indicated own natural color is the most beautiful. However, there are a considerable number of girls $(39.1 \%)$, who think blue or green is the eye color which looks more beautiful, and again, these eye colors are not common at all among Turkish Cypriots.

\subsubsection{Purchasing Girls' Magazines}

Question 23 asked the girls whether they are purchasing girls' magazines regularly. The results are listed below in Table 28.

Table 28: How girls' magazines are purchased

\begin{tabular}{|c|c|c|}
\hline $\begin{array}{c}\text { Type of purchase of } \\
\text { girls' magazines }\end{array}$ & No. of respondents & \% respondents \\
\hline Buy regularly & 24 & $\mathbf{1 5 . 4}$ \\
\hline Sometimes buy & 111 & $\mathbf{7 1 . 2}$ \\
\hline Read on the Internet & 4 & $\mathbf{2 . 6}$ \\
\hline Never buy & 16 & $\mathbf{1 0 . 3}$ \\
\hline No answer & 1 & $\mathbf{0 . 6}$ \\
\hline TOTAL & $\mathbf{1 5 6}$ & $\mathbf{1 0 0 . 0}$ \\
\hline
\end{tabular}

One interesting result that can be deduced from Table 28 is that only $10.3 \%$ of girls said they do not buy girls' magazines. $89.2 \%$ of girls are purchasing girls' magazines, or read magazines on the Internet. 


\subsubsection{Reasons for not Purchasing Girls' Magazines}

Question 24 asked those girls who said they do not purchase a girls' magazine the reasons for this. The results are outlined below in Table 29.

Table 29: The reasons for not purchasing girls' magazines

\begin{tabular}{|c|c|c|}
\hline $\begin{array}{c}\text { Reason for not buying girls' } \\
\text { magazines }\end{array}$ & $\begin{array}{c}\text { No. of } \\
\text { respondents }\end{array}$ & \% respondents \\
\hline Not interested & 8 & $\mathbf{5 . 1}$ \\
\hline $\begin{array}{c}\text { Too expensive } \\
\text { I read magazines bought by } \\
\text { others }\end{array}$ & 5 & $\mathbf{3 . 2}$ \\
\hline I buy women's magazines & 12 & $\mathbf{1 . 9}$ \\
\hline Other reasons & 3 & $\mathbf{7 . 7}$ \\
\hline No answer & 125 & $\mathbf{1 . 9}$ \\
\hline Total & $\mathbf{1 5 6}$ & $\mathbf{8 0 . 2}$ \\
\hline
\end{tabular}

Answers to the previous question indicates that the number of girls who do not purchase teen magazines adds up to 21 , however, 31 girls stated reasons for not purchasing girls' magazines. This may be due to the fact that some girls wanted to indicate they also buy woman's magazines. The most interesting result that can be drawn from Table 29 is that a considerable percentage of girls are actually purchasing woman's magazines.

\subsubsection{Girls' Magazines Purchased}

Question 25 asked girls who said they are purchasing girls' magazines to name the magazines they are purchasing. Girls were allowed to mark more than one answer for this question. The results are outlined in Table 30 below. 
Table 30 : Girls' Magazines purchased

\begin{tabular}{|c|c|c|}
\hline Girls' magazine & Total no. of choices & Only this magazine \\
\hline Hey Girl & 67 & $\mathbf{1 7}$ \\
\hline Cosmo Girl & 64 & $\mathbf{2 4}$ \\
\hline Go Girl & 39 & $\mathbf{1 0}$ \\
\hline Salsa & 51 & $\mathbf{9}$ \\
\hline Other & $\mathbf{1 2}$ & n.a. (not applicable) \\
\hline
\end{tabular}

Table 30 Shows that Hey Girl and Cosmo Girl are the two most popular magazines purchased by girls. Salsa is a 'low quality print' girls' magazine which started as a supplement of Milliyet newspaper. It has much fewer number of pages compared to other magazines, so it very cheap and it is sold for only 1 Turkish lira. Many girls who buy magazines purchase this magazine as a second one. Go Girl is a magazine for a lower age category, for girls between ages of 10 - 14 .

\subsubsection{Informing the Family about Purchasing Girls' Magazines}

Question 26 asked the girls whether they gave information to their family about purchasing girls' magazines. The results are given below in Table 31 .

Table 31 : Informing the Family about Purchasing Girls' Magazines

\begin{tabular}{|c|c|c|}
\hline Answer & $\begin{array}{c}\text { No. of } \\
\text { respondents }\end{array}$ & $\begin{array}{c}\text { \% of respondents } \\
(\mathbf{n = 1 5 6})\end{array}$ \\
\hline Yes & 106 & $\mathbf{6 7 . 9}$ \\
\hline No & 45 & $\mathbf{2 8 . 8}$ \\
\hline No answer & 5 & $\mathbf{3 . 2}$ \\
\hline TOTAL & $\mathbf{1 5 6}$ & $\mathbf{1 0 0 . 0}$ \\
\hline
\end{tabular}

Table 31 indicates that about one third of the girls are not informing their families about purchasing girls' magazines. 


\subsubsection{Favorite Place for Reading Girls' Magazines}

Question 27 asked the girls' the place they preferred for reading girls' magazines. The results are given below in Table 32 .

Table 32 : Favorite place for reading girls' magazines

\begin{tabular}{|c|c|c|}
\hline Favorite Place & $\begin{array}{c}\text { No. of } \\
\text { respondents }\end{array}$ & $\begin{array}{c}\text { \% of respondents } \\
(\mathbf{n = 1 5 6})\end{array}$ \\
\hline In my room, alone & 97 & $\mathbf{6 2 . 2}$ \\
\hline With friends & 32 & $\mathbf{2 0 . 5}$ \\
\hline In living room & 20 & $\mathbf{1 2 . 8}$ \\
\hline Other & 4 & $\mathbf{2 . 6}$ \\
\hline No answer & 3 & $\mathbf{1 . 9}$ \\
\hline TOTAL & $\mathbf{1 5 6}$ & $\mathbf{1 0 0 . 0}$ \\
\hline
\end{tabular}

Table 32 indicates that $62.2 \%$ of girls prefer to read girls' magazines in their own rooms, alone, in privacy. They do not want to share this reading experience with others.

\subsubsection{Most Favorite Girls' Magazine}

Question 28 asked girls their most favorite girls' magazine - the one that they liked most. The answers are listed below in Table 33 .

Table 33: Most favorite girls' magazine

\begin{tabular}{|l|c|}
\hline $\begin{array}{c}\text { Favorite girls' } \\
\text { magazine }\end{array}$ & Total no. of choices \\
\hline Hey Girl & 41 \\
\hline Cosmo Girl & 51 \\
\hline Go Girl & 35 \\
\hline Salsa & 29 \\
\hline Other & 13 \\
\hline None of them & 7 \\
\hline No answer & 5 \\
\hline TOTAL & 181 \\
\hline
\end{tabular}

Some of the girls marked more than one answer. These results, considered together with Table 30, confirm that the two most favorite magazines for Turkish Cypriot girls 
are Hey Girl and Cosmo Girl. Cosmo Girl, which is a magazine with a heavy translated content, and with most of the content prepared abroad, has a slight edge over Hey Girl as the magazine which is the most popular.

\subsubsection{Magazine Reading in the Last Week}

Table 34 : Have you read a magazine in the last week?

\begin{tabular}{|c|c|c|}
\hline Answer & $\begin{array}{c}\text { No. of } \\
\text { respondents }\end{array}$ & $\begin{array}{c}\text { \% of respondents } \\
(\mathbf{n = 1 5 6})\end{array}$ \\
\hline Yes & 61 & $\mathbf{3 9 . 1}$ \\
\hline No & 90 & $\mathbf{5 7 . 7}$ \\
\hline No answer & 5 & $\mathbf{3 . 2}$ \\
\hline TOTAL & $\mathbf{1 5 6}$ & $\mathbf{1 0 0 . 0}$ \\
\hline
\end{tabular}

Magazines are published at the beginning of every month and they are monthly publications. The questionnaire was applied in the middle of the month, so when asked whether they read any girls' magazine in the last week, $39.1 \%$ said yes, $57.7 \%$ said no. $3.2 \%$ of girls did not answer this question.

\subsubsection{Factors Affecting the Purchase of Girls' Magazines}

Question 30 asked the factors which affect girls' decisions in buying girls' magazines. The results are stated below in Table 35 .

Table 35: Factors affecting the purchase of girls' magazines

\begin{tabular}{|c|c|c|}
\hline Factor & $\begin{array}{c}\text { No. of } \\
\text { respondents }\end{array}$ & $\begin{array}{c}\text { \% of respondents } \\
(\mathbf{n}=\mathbf{1 5 6})\end{array}$ \\
\hline Cover photo & 15 & $\mathbf{9 . 6}$ \\
\hline Promotions & 15 & $\mathbf{9 . 6}$ \\
\hline Contents & 118 & $\mathbf{7 5 . 7}$ \\
\hline Other & 3 & $\mathbf{1 . 9}$ \\
\hline No answer & 5 & $\mathbf{3 . 2}$ \\
\hline TOTAL & $\mathbf{1 5 6}$ & $\mathbf{1 0 0 . 0}$ \\
\hline
\end{tabular}


Table 35 indicates that the most important factor girls consider when buying girls' magazines is the contents of the magazines.

\subsubsection{Factors Affecting Shopping of Girls}

Table 36 summarizes the findings on how girls are affected in making their shopping decisions. Almost $40 \%$ of the girls indicate their friends/peers play a role on their choices when they are buying things for themselves. A fourth of the girls said they take shopping decisions on their own. Family members and advertisements in girls' magazines were the other significant factors.

Table 36: Factors affecting shopping decisions

\begin{tabular}{|c|c|c|}
\hline $\begin{array}{c}\text { Who plays a role in } \\
\text { shopping decisions }\end{array}$ & No. of respondents & \% respondents \\
\hline Ads in magazines & 20 & $\mathbf{1 2 . 8}$ \\
\hline Friends/peers & 61 & $\mathbf{3 9 . 1}$ \\
\hline Family members & 25 & $\mathbf{1 6 . 0}$ \\
\hline Myself & 40 & $\mathbf{2 5 . 7}$ \\
\hline Other & 7 & $\mathbf{4 . 5}$ \\
\hline No answer & 3 & $\mathbf{1 . 9}$ \\
\hline TOTAL & $\mathbf{1 5 6}$ & $\mathbf{1 0 0 . 0}$ \\
\hline
\end{tabular}

The distribution observed in Table 36 shows that girls are most affected from their peers/friends in making shopping decisions. The second factor is their personal views. Family members and advertisements may also play a role, although their affect is smaller than the other two factors.

\subsubsection{Sections Liked Most in Girls’'Magazines}

In Question 32, girls were asked to indicate the section they liked most in girls' magazines. Girls were instructed to order the 10 sections listed from their most favorite section to their least favorite section. The results are listed below in Table 37. To give 
an indication on the general tendencies, number of first choices and the total number of first and second choices are given in Table 37.

Table 37: Sections liked most in girls' magazines

\begin{tabular}{|c|c|c|c|}
\hline Section & $\begin{array}{c}\text { No. of } \\
\text { first choices }\end{array}$ & $\begin{array}{c}\text { No. of first and } \\
\text { second choices }\end{array}$ & Rank \\
\hline Fashion & 51 & 75 & $\mathbf{1}$ \\
\hline Beauty tips & 18 & 53 & $\mathbf{2}$ \\
\hline $\begin{array}{c}\text { Shopping tips } \\
\text { Interviews with } \\
\text { celebrities }\end{array}$ & 5 & 15 & $\mathbf{7}$ \\
\hline Tests & 18 & 36 & $\mathbf{4}$ \\
\hline Tips on relationships & 1 & 39 & $\mathbf{3}$ \\
\hline Astrology & 12 & 9 & $\mathbf{8}$ \\
\hline Advertisements & 2 & 17 & $\mathbf{6}$ \\
\hline Letters of readers & 1 & 5 & $\mathbf{9}$ \\
\hline Posters & 18 & 5 & $\mathbf{1 0}$ \\
\hline
\end{tabular}

Table 37 shows that in girls' magazines, fashion is by far, the most favorite section of girls. It is followed by beauty tips. Tests, interviews with celebrities and posters of celebrities given as promotion are the third, fourth and fifth, respectively.

\subsubsection{Type of clothes that appear most in girls' closets}

In question 33, girls are given eight clothing and accessory categories, and they are asked to order their clothes in their closets from the one appears the most to the one that appears the least. Table 38 shows the first choices and total number of first and second choices for each category. 
Table 38: Type of clothes that appear most in girls' closets

\begin{tabular}{|c|c|c|c|}
\hline Category & $\begin{array}{c}\text { No. of } \\
\text { first choices }\end{array}$ & $\begin{array}{c}\text { No. of first and } \\
\text { second choices }\end{array}$ & Rank \\
\hline Jean trousers & 98 & 133 & $\mathbf{1}$ \\
\hline Jean skirts & 9 & 35 & $\mathbf{3}$ \\
\hline Fabric trousers & 3 & 11 & $\mathbf{4}$ \\
\hline Fabric skirts & 3 & 11 & $\mathbf{4}$ \\
\hline T-shirts & 36 & 99 & $\mathbf{2}$ \\
\hline Shirts & 0 & 6 & $\mathbf{7}$ \\
\hline Party clothes & 2 & 6 & $\mathbf{6}$ \\
\hline
\end{tabular}

Table 38 shows that the clothing item that appears most in girls' closets is jean trousers, by a great margin. T-shirts are also quite popular. Jean skirts are a distant third.

The content analysis performed on girls' magazines in this study indicates that the clothing item that appears most in magazine advertisements are jean trousers, followed by t-shirts. This shows a close correlation between the clothing items in girls' closets and the items advertised most in girls' magazines.

\subsubsection{Girls' Magazines and Daily Lives of Girls}

In the second section of the questionnaire, eight questions on how girls make use of the magazines in their daily lives were asked. The girls had to select an answer from five options, strongly agree, agree, neutral, disagree, strongly disagree. This is an application of 5-level Likert scale (Tezbasaran, A., 1997).

Three questions resulted in findings which are worth mentioning here. Answers for the other five questions are more or less evenly divided between 'agree' and 'disagree' options. 
Firstly, girls were asked whether magazines entertained them and helped them forget about their worries. The results are given below in Table 39.

Table 39: Magazines entertain me and help me forget my worries

\begin{tabular}{|c|c|c|}
\hline Answer & No. of respondents & percentage \\
\hline Strongly agree & 49 & $\mathbf{3 1 . 4}$ \\
\hline Agree & 57 & $\mathbf{3 6 . 5}$ \\
\hline Neutral & 32 & $\mathbf{2 0 . 5}$ \\
\hline Disagree & 10 & $\mathbf{6 . 4}$ \\
\hline Strongly disagree & 8 & $\mathbf{5 . 1}$ \\
\hline TOTAL & $\mathbf{1 5 6}$ & $\mathbf{1 0 0}$ \\
\hline
\end{tabular}

$67.9 \%$ of girls agreed or strongly agreed that girls' magazines entertained them and helped them forget about their worries. Only $11.5 \%$ disagreed. Secondly, girls were asked to indicate whether magazines helped them to direct their mothers or sisters 'correctly' when they are shopping together. The answers are given in Table 40.

Table 40 : Magazines help me correctly direct my mother or sisters

\begin{tabular}{|c|c|c|}
\hline Answer & No. of respondents & Percentage \\
\hline Strongly agree & 19 & $\mathbf{1 2 . 2}$ \\
\hline Agree & 60 & $\mathbf{3 8 . 5}$ \\
\hline Neutral & 35 & $\mathbf{2 2 . 4}$ \\
\hline Disagree & 28 & $\mathbf{1 7 . 9}$ \\
\hline Strongly disagree & 14 & $\mathbf{9 . 0}$ \\
\hline TOTAL & $\mathbf{1 5 6}$ & $\mathbf{1 0 0}$ \\
\hline
\end{tabular}

Table 40 shows $50.6 \%$ of girls agree or strongly agree that girls' magazines help them direct their mothers or sisters correctly in their shopping decisions. $22.4 \%$ were neutral, while $26.9 \%$ disagreed. 
Thirdly, girls were asked whether the clothes they wear fit them perfectly as much as they fit the celebrities in photos in girls' magazines. Table 41 outlines the answers for this question.

Table 41 : The clothes I wear fit me perfectly as much as celebrities

\begin{tabular}{|c|c|c|}
\hline Answer & No. of respondents & percentage \\
\hline Strongly agree & 22 & $\mathbf{1 4 . 1}$ \\
\hline Agree & 42 & $\mathbf{2 6 . 9}$ \\
\hline Neutral & 43 & $\mathbf{2 7 . 6}$ \\
\hline Disagree & 32 & $\mathbf{2 0 . 5}$ \\
\hline Strongly disagree & 17 & $\mathbf{1 0 . 9}$ \\
\hline TOTAL & $\mathbf{1 5 6}$ & $\mathbf{1 0 0}$ \\
\hline
\end{tabular}

Table 41 shows $41.0 \%$ of girls agree or strongly agree that clothes they wear fit them perfectly as much as they fit the celebrities that appear in photos in girls' magazines. $27.6 \%$ were neutral, while $31.4 \%$ disagreed. There is a slight tendency (by about $10 \%$ ) towards agreement that clothes would fit girls perfectly as much as they fit the celebrities.

\subsubsection{Body Satisfaction}

The third section of the questionnaire (Appendix A) contains a body satisfaction inventory which is composed of twenty-five questions, adapted from Ozgur et al.'s study (1998). The answers are again to be selected among the following options designed with a five-scale approach: very satisfied, satisfied, no opinion, not satisfied, and not satisfied at all.

The responses to the body satisfaction inventory indicate that the girls are mostly dissatisfied with their acne (50\% are not satisfied) and hairs on face (40\% are not 
satisfied) and body (50\% are not satisfied). For other body parts, no significant dissatisfaction is observed.

\subsection{Focus Group Findings}

Earlier, during the survey stage, height and weight information of 156 girls was collected, and their body mass index was calculated. I chose 82 participants from this sample, taking the approval of families and school administrations, to form six different focus groups, one for each age from 12-17 years. Each focus group comprised between 12 and 15 girls. Participation of the girls was voluntary upon approval from their parents, and the girls were readers of the two popular Turkish teen magazines, Hey Girl and Cosmo Girl, sold in North Cyprus.

The focus groups from the first school, Canbulat Özgürlük secondary school, consisted of adolescent girls aged between 12-14 years. The focus groups from the second school, Gazimağusa Türk Maarif College (GMTMK), consisted of adolescent girls aged 15-17 years. GMTMK has a middle school and a high school section, and accepts students through a competitive national entrance examination. Both schools are public schools.

As indicated before in section 3.4.3, the girls in each focus group knew one another well as they were all classmates, and so they were already members of preexisting social groups improving the effectiveness of the discussions (Bloor, Frankland, Thomas, \& Robson, 2000, p.23).

\subsubsection{Reading and Use of Teen Magazines}

Participants said that the magazines were "entertaining" and helped the reader to "have a good time." They also preferred to read the magazines because of "the news and 
interviews with their favorite celebrities," and they found beauty secrets and shopping tips in the magazines very useful. Suggestions in the magazines about how to form good friendships, including with boys, were important, and interviews with participants' favorite celebrities were also factors of choice.

The majority of focus group participants said that they bought teen magazines, which they were reading over and over, almost every night. They identified promotion material distributed by magazines, such as posters of celebrities or accessories, as a motive for purchasing magazines. Girls mostly preferred reading magazines alone in their rooms, but some also mentioned they sometimes read with their friends:

"I can read magazines with friends, but the issues to read will differ according to the closeness of my relationship with the friend." $(\mathrm{A}, 17)$

A small minority of the 17-year-olds said that they had read teen magazines such as Hey Girl and Cosmo Girl in the past, but as these had become boring, they became "interested in magazines for adult women like Cosmopolitan and Hülya." One 17-year-old participant commented:

"I used to read Cosmo Girl, but now me, my mother, and my sister are reading the same magazines, which are Cosmopolitan and Marie Claire ...” $(\mathrm{Z}, 17)$

A former reader of Go Girl magazine (which is preferred by 9-12-year-olds) said:

"When I was 10 years old, after reading my sister's Hey Girl magazine I could not continue with Go Girl anymore because the subjects in Hey Girl were more interesting." (M, 12). 
When they were asked which parts of the magazines they were more interested in, girls from the 12 year old group responded as follows:

"Mostly I read the information and clothes." (A, 12)

"I like the costumes." (S, 12)

"I look at articles about soul and body, and health issues... I look at clothes and the fashion of the year..." $(\mathrm{D}, 12)$

"I look at astrology pages, and photos. I read things about health..." $(\mathrm{T}, 12)$

"I look at coiffeur related things, hair care..." $(\mathrm{K}, 12)$

"I like pages about clothes and shoes, and for cosmetics..." (E, 12)

"I read for fashion news and tips, especially I get informed on what to wear where and when." $(\mathrm{D}, 16)$

"I look at the cover and check the posters. Also, if I am interested on the tests, (in that issue) I buy it." (T, 16)

"I look at magazine news and interviews." $(\mathrm{L}, 16)$

"I look at this year's summer fashion, what to wear this summer, how to do your hair..." (E, 17)

"There are tests for testing ourselves, these are helpful." $(\mathrm{O}, 17)$

“There are tests for friendship, I do not know how correct they are but I still do them thinking that they are somewhat correct." $(\mathrm{C}, 17)$

As the reasons for buying magazines, girls mentioned coverage about celebrities, new clothes, beauty products and recommendations about friendships:

“There are interviews with celebrities we like." (S, 13)

"I can follow the newest fashion." (I, 13)

"I find recommendations about friendships." $(\mathrm{D}, 13)$ 
“(Laughingly) I am interested in boys. I read interviews with my favorite celebrities, I learn new things about them.” $(\mathrm{H}, 14)$

"There is information about beauty secrets like how you should put nail polish on your toes, what to do for body care." $(\mathrm{C}, 14)$

\subsubsection{Beauty}

Participants were asked to define the image of ideal beauty. They responded that it is defined as being tall and thin, having pure white and shiny skin, blue or green eyes, small feet and a small nose, and long blonde or brunette hair. A small minority of the girls referred to black or brown hair or black-brown eyes.

When they were asked to define how a beautiful girl should look, participants mentioned the following:

1. A beautiful girl should keep her skin, hair, and body in good condition.

2. She should use makeup and skin conditioner for a pure silky skin.

3. She should dress coolly.

4. She should look attractive.

Some related remarks of girls are:

“A beautiful girl should wear make-up.” (D, 12)

"She should take care of her skin." (A, 12)

"She should do all kind of care taking for her body. She should be popular." $(\mathrm{B}, 12)$

"She should be attractive from men's point of view." $(\mathrm{N}, 13)$

"She should wear beautiful clothes and she should be fashionable." (Y, 13)

"She should be well cared for, attractive, she should neither be overweight, nor underweight..." $(\mathrm{G}, 14)$ 
Girls were asked to comment on the importance of being beautiful. Some selected responses are:

"To feel more comfortable in the society and to get socialized." (D, 15)

"I have to be beautiful so that the boy I like notices me (laughs)." (S, 15)

"In order to feel happy about myself." $(\mathrm{P}, 15)$

A small minority of girls in the 12-13 years age groups also mentioned "inner beauty." Some in the 14-17 years age groups indicated that it was important for a girl to look "natural" and not "artificial." They also stated that "beauty is a relative concept that can change from person to person." The importance of looking good without heavy makeup was also mentioned.

As an observation of the moderator is that, girls from smaller age groups were more naïve with regards to their appearance compared to the larger age group girls. Some larger group girls were using mascara and had partially dyed their hair, which was not observed in smaller age groups.

Some responses in smaller age groups indicated a wish to dye hair or use additional hair in different colors:

"I want my hair to be in different colors. I am going to dye my hair when I finish school to colors like red." $(\mathrm{A}, 14)$

"(the moderator sees that one of the girls has light purple and pink added hair) Teacher, this is added hair, I use it as bulk hair so nobody sees it... Outside of school I wear it freely." $(\mathrm{N}, 14)$ 
When they were asked about what color should a beautiful girl's eyes be, girls mostly mentioned blue, green and hazel:

"Blue-ish, hazel or light blue eyes. Especially when their skin is white, these colors go well for children and adults..." $(\mathrm{K}, 12)$

"If she has dark skin, blue or green, because it looks beautiful." (M, 12)

"Blue and green, which I always wanted as colors for my eyes." (T, 12)

However, participants in the 17 years focus group mentioned that some features could be appealing in other countries. For example:

“... when we go to a country like Germany or Russia, boys there like us ...” $(\mathrm{G}, 17)$

When the popularity of natural blondes with blue eyes in their school was questioned, sample responses were:

“... even if she is a blonde with blue eyes, she has some strange thing in her eyes or on her nose as an Easterner." (L, 17)

"A girl may be blonde and may even have blue eyes, but her nose might be big." (C, $15)$.

In spite of the desire to have blue or green eyes, a small minority of participants indicated that they accepted their own eye color owing to religious concerns:

"God created me with that eye color, if we do not like our looks, God may question us in the other world." $(\mathrm{B}, 12)$

Participants admired certain popular celebrities, and they defined body beauty standards according to those of the celebrities. A majority of girls that they would copy 
what some celebrities have done, namely, "aesthetic surgery will be a solution" when they are grown up.

Participants were then asked a question on the use of contact lenses. Even some girls in smaller age groups indicated use of lenses. Sample responses were:

"I am wearing blue lenses and I like using them." $(\mathrm{G}, 14)$

"I am now wearing colored lenses, but I am using them instead of glasses. I wanted colored eyes. I prefer using prescription color contact lenses, but when I take the lenses out, I look in the mirror and find my original eye color to be strange; I decided that I feel more comfortable with the lenses in.” (E, 17)

"We naturally have darker skin, black hair, and brown eyes. These [colored lenses] look different to us. So, if I want to try something different, I say let me try this once." $(\mathrm{L}, 17)$

Long hair was also very popular among the participants, and, indeed, they mostly had long hair, which is a tradition in North Cyprus. Participants also mentioned that whenever they are in a bad mood they "like to go to the hairdresser" and have "blowdried hair." Long hair was mentioned as one of the requirements of a beautiful girl stating the following reasons:

“(Long hair) shows you more attractive and more beautiful." (E, 15)

Shortening hair was not preferred as indicate in the following remarks:

"I tried short hair once, but I regretted it." $(\mathrm{H}, 15)$

"I never tried short hair and I will never try it in the future." $(\mathrm{K}, 15)$ 
Beauty secrets, such as "how to polish nails" and "facial/body care," were found to be as important as the information that participants received about fashion, hair styles, cosmetics, makeup, and accessories in the teen magazines, as shown in the following comment:

“The suggestions by girls' magazines such as using a cucumber for an eye pouch, foundation for pimples, eyeliner, lipstick, and lip polish, make people beautiful.” (P, 13)

When they saw advertisements for beach slippers and sandals, participants referred to foot shape and size. The favored foot qualities were "small size," "in elegant form," "cute," and "thin," and the foot should not extend beyond the shoe.

On the cover of one magazine that was shown to the 17 years age group, there was an advertisement which included a famous Turkish celebrity wearing heavy makeup and images of various makeup products such as lipstick and eyeliner. Participants commented on the cover page, with one stating that the cover page celebrity "looks like a prostitute," and others giggling. The labeling of the celebrity as a prostitute indicated the participant's conservative background. In contrast, others said that the model was attractive. The heavy makeup was considered to be an "inviting look." One response was that "she is trying to show how makeup makes one attractive," and another was that the advertisement was similar to those in women's magazines. One participant said "I wish I could go to school looking like her." The range of comments on the cover page from "attractive" to "too much for a young girl," indicated that for the participants makeup was something to be desired, but it was also degrading. They stated not only that "heavy makeup may be harmful and even may make one look 
ugly" but also that "some light makeup and softening creams may help one look beautiful."

Girls were asked whether they would like to be a cover girl, the responses were:

"I would like to be one. On one hand it is good, but on the other hand, some may be jealous of me, and they may talk after me.” $(\mathrm{D}, 12)$

"I would like to be a cover girl, but there is a possibility that I will not be selected." $(\mathrm{A}, 12)$

"I would like to be one, I would like to appear on magazine covers with nice pose." $(\mathrm{S}, 12)$

"If I become beautiful, I may be." $(\mathrm{K}, 13)$

"I would not like to be one. Someone might color my face with a pen and humiliate me. I could see that cover on the floor and feel sorry." (F, 13)

"Consider this, people will purchase the magazine and the first thing they will see will be your face." $(\mathrm{A}, 14)$

"I would be happy if people liked me." (G, 14)

"I filled in an application form once, but then I changed my mind." $(\mathrm{B}, 15)$

"I do not want it because everyone will see me like that and it will not be appropriate for my family." $(\mathrm{N}, 15)$

"I would like to be a cover girl but I would like to be inside frequently as well, I wouldn't want to be a temporary one." $(\mathrm{G}, 16)$

However, in older age groups girls indicated they are aware of the fact that cover girls and others do not appear in their natural looks:

"I think none of them (cover girls) look natural." $(\mathrm{O}, 17)$ 
“(They look) over exaggerated." (E, 17)

When participants were discussing the reasons why being beautiful was important, an interesting comment was:

“... it is important to a point. Consider that you are looking for a job which is difficult to get, especially in times of economic crisis. Would they select a beautiful, attractive woman, or one who has neglected looking after herself? Of course the beautiful one, the attractive one wins. It is in general like that, you get some extra points!" $(\mathrm{C}, 16)$

In addition, in spite of participants' desire for makeup, sexy looks, and feminine charm, they used these terms to criticize others for seducing boys with those qualities:

"Popular girls use make-up, wear a mini skirt, like to show all their stuff, they are spoilt, and they would like to have boys running after them.” $(\mathrm{A}, 12)$

“(Popular girls) dress openly, trying to look extremely cool, trying to have boys running after them all the time..." $(\mathrm{E}, 13)$

"There are girls who want to show all (parts of) their body." $(\mathrm{K}, 13)$

"They wear miniskirts and they are as if going to somewhere else but not to school." $(\mathrm{N}, 13)$

When participants spoke about beauty, they often used English words that are prevalent in teen magazines such as "fit," "slim," "cool," "body," "trend," "style," "eyeliner," and "lip gloss."

\subsubsection{Consumption: Fashion, Beauty, and Brand Products}

The analysis in regard to consumption behavior showed that all participants either bought beauty products themselves, or used products purchased by their mothers or 
sisters. They often stated that "one has to use makeup," "you should take good care of your skin," "you have to use skin cream for softening the skin," and "you have to have well-kept hair." The advertisements on beauty products were useful because they informed readers about "the new products and brands." One participant said "This information is very useful if you are going to a wedding ceremony or if you have a date with your boyfriend." Others said that they used beauty products such as moisturizers, tanning lotion, and products for treating black facial dots, and also "wellknown brand products should be used." Eyeliner, hand and body creams, face tonic, makeup cleanser, tanning lotion, nail polish, perfume, lipstick, and mascara were mentioned as the beauty products that they used. There was a general agreement that everyone should use an anti-aging cream. A small minority of girls believed that they would require facial peels, Botox, or face lifts in the future. Girls from the 15 year old group mentioned that they started using make-up at early ages during their middle school days.

One interesting remark about using make-up is:

"Well, when I feel bored and I want to feel more beautiful, I do make-up." (H, 16)

Even some participants in the smaller age groups mentioned use of beauty products, while in older groups daily use was mentioned:

"Sometimes I use creams, to soften my hands." $(\mathrm{D}, 12)$

"I use cosmetic products like creams for skin care and some perfumes, without harming our health.” $(\mathrm{K}, 12)$

"I do not use make-up regularly, but I use a slight amount of make-up when I am going to weddings." $(\mathrm{A}, 12)$ 
"Cosmetic products are very useful when you go to a party or a birthday party, they show you beautiful.” $(\mathrm{Y}, 13)$

"Beauty products are helpful when you are going to a wedding, or for example, when you are meeting with your boyfriend (laughs)..." $(\mathrm{K}, 13)$

"I do some make-up, not a heavy one, I use eye liner, mascara, and some lip gloss, that is all." $(\mathrm{P}, 13)$

"I use sun blocking cream to avoid sun spots on my skin." $(\mathrm{B}, 15)$

"I use creams on a daily basis." $(\mathrm{K}, 17)$

Girls think when one gets older, using beauty products will be a must:

"If my face was not this young and I had to buy something (face cream) expensive, I would buy it... when we get older, we shall use this type of products a lot. (laughs)" $(\mathrm{O}, 17)$

"Since these products are being used all over the world, they are definitely helpful (for skin care), and you should prefer brand products.” (E, 17)

Participants who were using blue or green contact lenses stated that they also used special conditioners to care for their hair. One said that using makeup at an early age may cause some problems, but one could still continue to look natural by using other treatments such as "shiny products, creams that keep the skin, hands, and face smooth.”

Other responses were:

"A beautiful girl should take care of herself properly to be attractive, and she should not be too fat or too thin." $(\mathrm{A}, 12)$ 
"You have to wear makeup to look beautiful and use all kinds of treatment for body care.” $(\mathrm{C}, 12)$

"We are doing all this shopping to feel good and to look better for the boys." (N, 13)

There were also claims that beauty cannot be achieved by wearing makeup only, because dressing well and maintaining one's hair are required at all times. The idea of not using makeup was supported as long as "the latest fashion is followed." For example, "If purple is the color of this year, one shall wear something purple."

Selected comments about brand products were:

"Brand is important, it shows quality. Also, brand products look cooler." $(\mathrm{K}, 13)$

“The people around (my friends) give importance to brand products. I don't know what they would say if I don't wear brand products." (T, 13)

"I don't feel good if I wear non-brand products." (B, 13)

"I feel bad if I do not use brand products." $(\mathrm{G}, 14)$

"I love products by Adidas. I always wear Adidas products. However, I feel terrible if I cannot buy something I want. For example I liked some sportswear but there was no size suitable for me, I had to wait for one week, but eventually I bought it." $(\mathrm{N}, 14)$

"I feel demoralized when my shoes are not Nike." (S, 14)

"If it is not a brand product, it will wear down quickly. If it is a brand product, it will have higher quality." $(\mathrm{B}, 15)$

Girls mentioned how magazines shaped her shopping decisions as follows: 
"For example teen magazines show best presents you can buy for your mother for the mothers' day, or for your father for the fathers' day, or best birthday presents for your friends. I look at best places where you can do your shopping...” (S, 12)

"I look at various clothes that appear in magazines, and when I see something beautiful, I want to find it and then buy it..." $(\mathrm{O}, 17)$

Participants also felt good when they went shopping:

"I become happier, joyous, for example when I buy a cloth I like it very much and I do not want to take it off for days." $(\mathrm{A}, 12)$

"I get rid of all my worries during shopping." $(\mathrm{K}, 13)$

"I feel comfortable and unrestricted." (D, 13)

"I feel better after doing shopping and I present a better image. After shopping, especially after buying brand products, I feel as if I am reborn and I get rid of my nervous stressful state. However, the feeling of happiness after shopping does not last long, I put on my new clothes that day but I throw them away, and eventually, there is a desire to do more shopping." (E, 14)

"I feel very good, like I am reborn. I get rid of my stress and angry mode." $(\mathrm{B}, 14)$

"I feel happy when I go to shopping with my friends." $(\mathrm{K}, 16)$

"We both feel better and (by buying things) we look better to boys." (A, 17)

However, girls also mentioned happiness of buying a new cloth does not last long:

"My happiness continues until I take it off." $(\mathrm{A}, 12)$

"Sometimes I feel sorry for not buying the other one, which was more beautiful. So, I feel happy and regretful." $(\mathrm{D}, 12)$ 
"I am also regretful. For instance, I bought one, OK, but I should have bought the other one as well. Deciding which color to buy is difficult. So I am happy that I bought something, but I also think may be the other color could suit me better..." (E, 12)

"When shopping is over, my mood goes down again." (E, 14)

"My happiness does not last long, I wear the new cloth and I am happy for that day, but when I take it off, say the next day, it is over." $(\mathrm{B}, 14)$

"My happiness lasts until I buy something else for it." (N, 15)

"I become bored of it in a week." $(\mathrm{T}, 15)$

"I am very happy first, but in a few hours it is over." $(\mathrm{Z}, 16)$

Some girls in older age groups had remarks and complaints on the expensiveness of products advertised in magazines:

"Last time when I was reading (a magazine) it had an advertisement showing a bag worth 1,450 Turkish Liras (almost 1,000 US dollars). This is very expensive for most of the readers... The prices shown in magazines for clothes and shoes are very expensive" $(\mathrm{O}, 17)$

Participants preferred to purchase clothes, makeup, magazines, and phone tokens with their allowance. However, they stated that they mostly asked their parents to buy expensive beauty products or brand clothing because their allowance was not sufficient to purchase the desired products. They also indicated that they spent money on clothes and beauty products that were covered extensively in the teen magazines.

\subsubsection{Teen Magazines as the Secret Garden of Adolescent Girls}

Participants said that as teen magazines were "entertaining" and helped the reader to "have a good time," they liked reading them over and over. 
"When I buy a magazine, I read it the whole day and finish it. Then, when I have spare time, during evenings, I take a look at it again and again.” $(\mathrm{D}, 13)$

A large majority of participants indicated that they preferred reading magazines in the privacy of their rooms.

They indicated that they were interested in tests that investigated their relationships with boyfriends and other friends, and that tests were helpful in understanding one's own personality. They were also quite interested in the astrology pages.

Some responses showed that participants were concerned with being liked by boys:

"Let me speak frankly; boys show more interest in girls who wear sexy clothes ..." $(\mathrm{T}, 16)$

This comment demonstrated that they thought that boys their age were interested in girls' sexy clothes.

A large majority of the younger age group participants were not comfortable talking about sexuality in front of their peers. They even said they cannot talk on sexual issues with their counselor teachers of their schools. Only a few of them said they can talk about sexual issues with their mothers. One girl said:

"You can send questions to magazines for these issues." (G, 16)

When asked about whether they make use of information given in magazines about boys or sexual issues, they responded as follows: 
"I sometimes make use of information about boys." (D, 12)

"I cannot share information about sexual issues with my mother, but there is a girl older than me called Gülsüm, I share with her.” $(\mathrm{M}, 12)$

Those who did talk had different opinions on how, when, and from where issues related to sexuality should be learned:

"Hey Girl is covering interviews with doctors beside the issues on menstruation, which are embarrassing subjects to talk to anyone else about." $(\mathrm{Z}, 16)$

"Actually, they raise our consciousness on sexual issues. I turn the pages quickly when I am with my parents. However, when I am alone, I take my time to read private issues in the comfort of my room." $(\mathrm{T}, 13)$

"I find and use some websites that are mentioned in those magazines. If there is an Internet connection, we enter these sites. There is a part which says girl-to-girl. Girls say things about themselves; we like to enter those sites." $(\mathrm{K}, 12)$

“... nowadays, girls are having life experiences 3-4 years earlier than they should, and they have already lived and learned everything." $(\mathrm{O}, 17)$

"They just think that they know, but they just act; actually, their knowledge is limited. Families are also very important. They should inform their children so that children do not make mistakes at young ages.” $(\mathrm{L}, 17)$

\subsubsection{Professional Advice}

Girls indicated the lack of information on professional advice in magazines:

"There is no information in magazines on professions." $(\mathrm{C}, 14)$

"The youngsters in the magazines only like entertainment or fooling around. So, in the end the readers are inclined to imitate them. However if they put things about professions, people would be better informed." $(\mathrm{C}, 17)$ 
In the magazine issues that were handed out to participants, adolescent girls were described as being dependent, with a keen interest in boys. The older age group participants rejected this "stereotypical role" when they examined the magazines, noting that it made it difficult for them to develop their own independent life styles.

“... that is really the problem about these magazines. They consider events from a shallow point of view. Instead, there are many girls who, after reading a lot about celebrities, try to shape their lives like celebrities. Even if some girls are not influenced, many are influenced.” $(\mathrm{H}, 17)$

\subsubsection{Body Satisfaction}

With regards to participants' body satisfaction, I collected weight and height data from the 82 girls who took part in the focus group study in the two schools. I found that $24.4 \%$ were classified as underweight, $67.9 \%$ as normal, $7.1 \%$ as overweight and only $0.6 \%$ as obese. Thus, more than $90 \%$ of the participants fitted into a normal or underweight category according to body mass index definitions by Cole, Flegal, Nicholls, and Jackson (2007).

When asked whether or not they find themselves beautiful, about half of the participants said that they were not happy with their body and that they were planning to go on a diet in the near future. Some didn't like their skin color or the color of their hair and eyes, and some said that they would like to be taller and/or thinner:

"I would like to have a whiter skin and green eyes." (A, 12)

"I wish I was taller and I had blue eyes, also I would rather have a white skin instead of this dark one." $(\mathrm{N}, 12)$

"I would like to be blonde." (M, 12) 
"I am not happy with my weight, I am distressed and I am trying to go for sports now.” $(F, 16)$

"I am also not happy (with my weight), I need a real diet this summer (laughs)." (Z, 16)

"I am one of those who starts a diet on Monday, and finishes the same day." (Y, 16)

\subsection{Interpretation of the Findings}

In this section, findings stated above for each research method used separately will be merged together and considered with respect to the research questions.

Research Question 1: Do teen magazines influence Turkish Cypriot adolescent girls' perception of ideal beauty?

Research Question 1 asked if the teen magazines influence Turkish Cypriot adolescent girls' perception of ideal beauty. The content analysis study has demonstrated that on magazine covers mostly blondes and brunettes with colored eyes were represented. Although answers to the questionnaire indicates girls mostly marked "natural color" choices for most beautiful hair and eye colors, responses of the focus group study has shown, similar to Meyers' (1999) and Tiggemann's (2012) findings, participants defined the image of ideal beauty as being tall and thin, having pure white and shiny skin, blue or green eyes, a small and upturned nose, long blonde or brunette hair, and small feet, although the girls mostly had dark hair and eyes. This finding supports the findings of Sauer and Robles-Pina (2003), who mentioned a relationship between the contents of magazines that girls read and their perception of beauty. The disagreement between the questionnaire results and focus group findings can be explained by the wish of girls trying to give ideal answers to questions, instead of what they actually think. 
Considering focus group participants' tendency of defining ideal beauty standards according to those of the celebrities, and content analysis results of both Cosmo Girl and Hey Girl covers, girls do want to look like the models and celebrities they see on magazine covers and inside the magazines, similar to findings of Shields and Mayhew (2001). From these results, it is possible to say that teen magazines reproduce a beauty ideal and deliver their messages to their target population while making teen girls question their beauty, constantly comparing themselves with the celebrities and models presented as young women with ideal bodies. Similar to Redcross and Grimes' (2014) findings which list celebrity gossip as one of the popular topics in teen magazines, frequent presentation of celebrities which fit to western beauty standards may have a cultivation effect on girls with regards to their understanding of ideal beauty.

Furthermore, the content analysis study indicates that messages about the appearance such as "shape your legs", "work out your abdomen", "make your hips tighter", "strengthen your arms", "techniques to mow grass", and "make your shoulders explicit", along with series of beauty tips and suggestions are all signs of encouragement provided by the magazines for reaching the beauty ideal that is presented as “in one's reach".

In addition, healthy nutrition tips such as "You should not have kilograms of problems" may be considered as building a bond between the physical appearance and other social issues encountered by the teens. 
Research Question 2: Do teen magazines promote Turkish Cypriot adolescent girls' consumption behavior in regard to cosmetics and fashion brands?

Research question 2 asked if magazines promote Turkish Cypriot adolescent girls' consumption behavior in regard to cosmetics and fashion brands.

The distribution of advertisements among product categories which is presented in the content analysis section show that almost one third of advertisements in girls' magazines are for fashion products. A similar pattern can be seen in the distribution of shopping tip categories where fashion again emerged as the most prominent category. Beauty tips followed fashion, where the magazines linked beauty tips with the beauty product advertisements in an attempt to present an understanding that certain beauty goals achievable through these products. From this it can be argued that, girls buying these magazines see repeated messages for purchasing the products that are presented, whether consciously or subconsciously. In the focus group study, girls indicated that advertisements on beauty products are informatory and useful. Even the smaller age group girls mentioned use of a large variety of beauty products, showing the possible effects of advertisements and shopping tips. Girls considered teen magazines as 'useful' for providing them with the information about new products and brands while giving tips for how to use make-up, take care of their skin, hair, and their body.

The survey results has shown that when factors affecting shopping of girls were investigated, the effect of advertisements in magazines is the fourth important item with almost $13 \%$ when compared with the friend and family views which are $39 \%$ and $16 \%$ respectively. When it is known that sections liked most in girls' magazines are 
fashion and beauty tips as demonstrated by this study, this is coherent with the overall averages of the content analysis study which show that fashion and beauty tips emerge as the most popular categories used by the editors of the magazines. Furthermore, when the overall averages are considered, shopping tips and advertisements together constituted almost half of the content of the magazines. This is consistent with studies conducted on similar teen magazines such as Seventeen, which indicated that half of the magazine space is dedicated to advertisements (Massoni, 2001).

The interaction between magazines and girls could be clearly seen when they were asked the type of clothes that appear most in their closets. The content analysis performed on girls' magazines in this study indicates that the clothing item that appears most in magazine advertisements are jean trousers, followed by t-shirts. This shows a close correlation between the clothing items in girls' closets and the items advertised most in girls' magazines. Similar findings are obtained from the questionnaire.

Another finding of the questionnaire is that more than $42 \%$ of the girls said they prefer to purchase clothes, accessories and beauty products with their allowances, whereas, only $28 \%$ said they prefer to purchase food. Similarly, in their choices for future purchasing plans, combination of clothes, accessories and beauty products is the first category. In addition to this, the focus group study showed that since some beauty products are expensive, girls are asking their mothers and elder sisters to purchase them.

The survey study shows almost $55 \%$ of girls think brand is important, and listed looking cool, using high quality and dependable clothing as main reasons of 
importance of using brand products. Similarly, the focus group study found that girls linked brands to quality which perceived as a mediator to achieve social acceptance in their environment, while they stressed the fact that they spend money on clothes and beauty products that are covered in the teen magazines.

For purchases with their allowances, they give equal priority to buying food and drinks from school canteens, and buying clothes. Although buying food and drinks is a basic need, they mostly purchase packaged food and soda, which are not healthy, but still advertised in teen magazines.

The survey results show that about $50 \%$ of the girls think magazines help them direct their mothers or sisters correctly with regards to their shopping decisions. The content analysis results indicated that there are sections in magazines containing information for girls on how to direct their mothers to buy and use some beauty products, as indicated in section 4.2.7.5.

Therefore, this study supports the research question statement that teen magazines promote Turkish Cypriot adolescent girls' consumption behavior in regard to purchasing decisions on cosmetics and fashion products.

Research Question 3: For what reasons do Turkish Cypriot adolescent girls read teen magazines?

Regarding to the third research question which investigated the reasons behind Turkish Cypriot adolescent girls' tendency to read teen magazines, this study has pointed out the following results. 
Focus group participants defined teen magazines as entertaining, and helping them to have better time. In the survey study, as an important reason for reading teen magazines, more than two thirds of girls agreed or strongly agreed that girls' magazines entertained them and helped them forget about their worries. Only about $12 \%$ disagreed with this statement.

Focus group study also showed most of the girls preferred to read magazines alone in their rooms. This is in line with the survey results where 60 per cent of the participants presented their favorite place for reading teen magazines as alone in their room. In the focus group study, one of the main reasons for this need of privacy emerged as being uncomfortable to talk about their sexuality with their peers as well as their family. Similarly, a study conducted by Walsh and Ward (2010) found that more frequent reading of magazines was accepted to be an intermediary for improving sexual health knowledge. Therefore, teen magazines seem to be a source of information for the questions that girls are not able to ask to their parents or friends easily.

The questionnaire results have shown that more than $75 \%$ of girls purchase magazines mainly for the contents. Cover and promotions are chosen by only $10 \%$ each of girls as the main reason for purchasing. However, in the focus group study, an important motivation for buying these magazines emerged as the promotion material distributed by magazines that came in the form of posters of celebrities or accessories distributed free with magazines. Other reasons were stated as the news and interviews with their favorite celebrities, and beauty secrets and shopping tips. Advices on friendships and relationships were also a source of motivation. These results are also similar to 
questionnaire findings which shows that the sections liked most in teen magazines are fashion and beauty tips, followed by tests and interviews with celebrities.

Research Question 4: Are Turkish Cypriot teenagers happy with their current appearance?

The fourth research question of this study asked whether Turkish Cypriot adolescent girls are satisfied with their appearance, i.e. their body satisfaction.

The dieting section of the questionnaire indicated that more than $40 \%$ of the girls had some dieting experience and almost half of them plan to go on a diet in the near future. Similarly, almost half of the girls interviewed in the focus group study said they were planning to go on a diet in the near future. In contrast, body mass index calculation of this study has shown that more than two thirds of the girls were in the normal weight category, about a quarter of them were underweight, while only 7 per cent of them fell into overweight category.

More importantly, out of the under-weight body mass index (BMI) girls, almost one fifth said they have had a diet experience in the past, $10 \%$ of them were currently on diet, and almost $40 \%$ of them were planning to go on diet in the near future. For the over-weight BMI girls, $82 \%$ have said they had a diet experience, almost two thirds are on diet, and more than $70 \%$ said they are planning to go on diet in the near future.

These results show that girls are not satisfied with their weight, although most of them are scientifically in a normal or underweight category. This finding supports Sauer 
and Robles-Pina's (2003) finding which indicates that most of the teen magazine readers perceive themselves as overweight even when they are not.

In the focus group study, when asked whether or not they find themselves beautiful, about half of the participants said that they were not happy with their body. Some didn't like their skin color or the color of their hair and eyes, and some said that they would like to be taller and/or thinner. Thus, it can be concluded that a majority of girls were not happy with their body. Magazines may also be playing a role in this low degree of body satisfaction as indicated by Duke (2000), Jones et al. (2004) and Coleman (2008). 


\section{Chapter 5}

\section{CONCLUSION}

In this conclusion chapter, a discussion on major findings will be made and suggestions for further studies will be stated.

\subsection{Discussion}

The findings of this study show that the Turkish Cypriot girls are in favour of reading teen magazines and their definition of ideal beauty is similar to the image of ideal Western beauty promoted by teen magazines. Duits (2010) indicates that in everyday girl culture, "there is a dominant perception of popular culture as trivial" (p. 254). Similar to this remark, the "Western beauty standard", now seems to be a part of the Turkish Cypriot girls' culture and it is taken for granted by girls.

Although in some cases teens refer to physical differences other than the ideal beauty as being acceptable, the basic model remains as thin, blond and white skinned, with an upturned nose and large blue or green eyes, similar to Tiggemann's (2012) ideal beauty definition. For example, according to focus group findings, blue contact lenses for eyes was especially preferred because it was different and fits the definition of ideal beauty better. In contrast, most of the participant girls had dark colored hair and eyes.

As for the hair color, in the survey study, although a majority of the girls choose the option "own natural color" as the most beautiful hair color, $14.1 \%$ of girls selected 
blonde or red as the color which shows a girl beautiful. These colors are not at all common among Turkish Cypriots, but they appear frequently in magazine covers. Similar to the hair colors, in the questionnaire, there are a considerable number of girls $(39.1 \%)$, who think blue or green is the eye color which looks more beautiful, and again, these eye colors are quite rare among Turkish Cypriots.

Interestingly, in the focus group study, girls indicated that later they can change the color of hair easily by dying it whenever they want and to whatever color they like, which shows a wish to change their hair color. It was observed that some larger group girls had partially dyed their hair, which was not observed in smaller age groups.

Also, in the focus group study, girls specifically mentioned blonde or brunette as most beautiful hair colors and blue, green and hazel as the most beautiful eye colors. Similarly, blonde and brunette are the dominant hair colors on covers according to the content analysis study, and it was found that celebrities and cover girls appearing on magazine covers mostly had blue, green or hazel eyes. Thus, focus group and content analysis findings show similarity according to hair and eye colors.

To change the color of one's eyes, using colored lenses is an option. However, most of the girls said it is easy to understand whether one is using lenses, so it does not look natural. Possibly, if lenses looked more natural, they could have preferred using lenses to change the color of their eyes like dying their hair, which some girls indicated as a technique they use to change their hair color while on vacation. 
However, responses show girls are aware that ideal beauty is difficult to attain, as one may have at least one unfitting physical appearance. Girls also think that beauty standards may change from one society to another. They are aware that blondes may be preferable in a culture in which majority of the girls have black or brown hair, but not in another culture where blondes are dominant.

During the focus group study, a question on popular girls liked by boys in their school was directed to girls. Participants in all age groups were mostly angrily explaining that popular girls use heavy make-up, wear miniskirts, and they would like to have boys running after them. In the Western world, being popular in school is a positive attribute, but girls in North Cyprus think differently, and it is perceived as a negative attribute.

This study offers evidence that there is body dissatisfaction among teenage girls since they think they do not look like the ideal beauty. This finding reminds Coleman's (2008) remark that "impossible images" presented in magazines cause girls to be depressed and dissatisfied about their bodies (p.173). It is interesting that although girls already had young skin, they still believe that they should use beauty products to obtain smooth and shiny skin, for looking beautiful and to attract boys. This fact reminds similar findings by Labre and Walsh-Childers (2003) who stated girls think beauty is a requirement for girls and they are given the message that beauty can be achieved by using beauty products offered by the magazines. Complaints and worries for non-existent problems such as eye pouches were seriously taken into consideration, and girls were interested in products that would remove those, even if they had none. The focus group study indicates that magazines have affected girls about their body 
image perception, like Voelker, Reel, and Greenleaf (2015), who report similar findings.

Attracting the attention of boys seems to be a major worry for the girls as indicated by the focus group findings. Content analysis study also shows that magazine contents include various advices on how to have influence on boys by looking beautiful. This is in-line with findings of a content analysis study on Seventeen magazine (Fuller, 2005) stating that it has contents encouraging girls to make themselves as beautiful as possible to attract boys and physical appearence is the most common theme appearing in Seventeen. Similarly. Kim et al. (2011) report that a major issue covered in Seventeen and Teen Vogue magazines is how to improve one's appearence using beauty products, fashion and dieting.

Focus group findings also indicate that there is a desire to get thinner by dieting, even if they are not overweight, a result similar to findings of Sauer and Robles-Piña (2003)'s study on teenager girls in Portugal. The study by Crossley, Cornelissen and Tovee (2012) indicates that women define ideal body measures as something very difficult to achieve and 39 out of 40 women who took part in the study had higher BMI ratios then their ideals. I think thin ideal body images presented in magazines contribute to girls' body dissatisfaction considering my findings on BMI versus dieting experiences of girls that took part in this study.

Answers of participants in the focus group study showed that girls feel happy, at least for some duration, when they do shopping. Also, they say they go to a hair dresser or shopping when they feel depressed, in order to get rid of their stress. 
Although the magazines influence teens for body image and consumerism, the results also reveal that Turkish teenagers believe some body image messages in magazines are contrary to some of their traditional values and culture. Other factors effecting the beauty image accepted are the cultural values of the society, peers and family. Girls who were coming from more religous backgrounds showed signs of accepting their looks and hence reducing the stress related with beauty issues. This finding is compatible with Ekși, (2001), who states that for young adolescent girls, religion is supportive in reducing stress and making it easier to endure anxiety.

The study has found that girls begin to purchase and use beauty products at ages as early as 12 , to become fit and to attain looks that are similar to the beauty ideal. These products are heavily advertised in the media, and the girls have a strong belief that they are used by many women and girls in different countries. So, they spend a lot of money for these items and they are considered as important and valuable customers by the marketing sector. Also, this study has shown that fashion and beauty product advertisements constitute more than two thirds $(68 \%)$ of all advertisements in teen magazines (Appendix B).

One other finding of the content analysis study is the advertisers are sometimes using a more friendly language to persuade girls to buy their products. On the other hand, in some advertisements, a different type of advice-giving language is used. Some advertisements are organized in such a way that they look like the advice-giving pages of magazines. 
Since advertisements and shopping tips constitute almost half of magazine pages, a content analysis was conducted on the advertisements appearing in the teen magazines considered in this study. The results showed that a big majority (70\%) of advertisements are giving traditional messages. Only a very small minority of advertisements are found to give feminist messages. Trimble-Clark (2012) who anlayzed articles in the Seventeen magazine reports that they also contain mainly antifeminist messages. Her findings show that $73 \%$ of messages are anti-feminist in nature.

Similar to de la Ville's (2007) findings indicating girls believe magazines can help them find the right products, girls taking part in this study said they find the information given by magazines on new products and latest fashion trends very useful and influential in their shopping decisions. The focus group findings indicate there was a strong belief among the girls that the models and celebrities who appear in magazines use many different beauty products to look beautiful and to sustain their beauty. The girls think they should also use similar products. Brands are important and girls were not feeling good when they had to wear non-brand products. The results show that for the teenage girls, brand equals quality. This finding supports Wolf's (1991) explanation on why teenagers prefer brand products.

Girls seem to be interested in similar brand products, similar life-styles (like those of celebrities), and similar worries on having to buy presents on special days like the Mother's day or the Valentine's Day, which were actually not a part of Turkish culture until lately. The magazines were identified as guides on their choice of presents for special days. The information about "places where can one do the best shopping" is 
found to be especially useful. When they were asked about what clothes they have in their closets, they indicated jeans, t-shirts and accessories that are in-line with the coverage in advertisements in girls' magazines. They want to become unique in terms of their clothing and the products they purchase, under pressure from their peers and the media that promotes beauty standards and trending fashion. Therefore, without being aware, they become monotype life-style individuals as indicated by (KulaDemir, 2004).

The content analysis study showed sex and relationship-related articles in teen magazines occupy more than $14 \%$ on the average and is ranked fourth. Girls participating in the focus groups showed a special interest in sex-related issues, which shows sex related issues is a major concern. Similar findings are reported in the literature, such as Kim and Ward (2004). Although sexuality is not directly covered in girls' magazines, it is indirectly implicated in frequent advertisements such as those about birth control pills (one advertisement even claimed that birth control pills reduce acne). Girls from 16 and 17 years old groups mentioned that sexuality becomes an important issue at a very young age, and they believe that many girls learn topics of sexuality from girls' magazines, instead of their family or their school, and magazines may help provide information about sexual issues. This finding is similar to the findings of Walsh and Ward (2010) who state that teen magazines might be an important source to learn about issues related with sexuality.

Girls reported they prefer to read magazines in their rooms and they get pleasure by reading them over and over. This finding supports the statements of Radway (1991) who reports young women take pleasure by reading romance novels and popular 
literature. Girls were also interested in personality and relationship tests and astrology pages. Especially among the younger age groups, astrology pages were taken seriously. It was observed that girls from smaller age groups were more naïve with regards to their appearance and speech compared to the larger age group girls. As indicated by Öztürk (2000) in his study on television's place on children's political socialisation, as children grow older, they perceive the information better. Some girls in smaller age groups thought astrology pages were prepared by scientists and they took the recommendations on those pages as granted.

The content analysis study indicated some use of English language words in magazines. Firstly, it should be noted that the names of the two magazines which are subjects of this study are in English. Even magazine names for smaller age groups published in Turkey are also in English, like Barbie and GoGirl. It was interesting to see that while speaking in Turkish, girls were using some English words and idioms that relate to beauty and body image, that are borrowed from the 'jargon' of the teen magazines like "fit, trendy, cool". This shows the effect of magazines in daily language causing use of foreign words for beauty and body image definitions.

In the literature, some researchers report that children read teenage girls tend to read adolescent magazines and tweens read teens magazines (Sauer and Robles-Pina, 2003; Vares and Jackson, 2010). The study by Vares and Jackson (2010) reports that tweens ${ }^{9}$ in New Zealand read at least two of three teen magazines (Crème, Girlfriend and Dolly) published in Australia and New Zealand. In Sauer and Robles-Pina's study

\footnotetext{
${ }^{9}$ The term tweens refers to children with 8 to 12 years of age
} 
(2003) on magazine reading habits of adolescent girls, besides Seventeen and YM, Cosmo (the adult version of Cosmo Girl) was reported as one of the most-read magazines. A similar finding from our focus group study has shown that some Turkish Cypriot teenager girls, especially those older than 16 years of age are reading women's magazines and consider teen magazines as childish, and reading them as a waste of time.

In parallel with the present literature (Durham, 1998; Chow, 2004; Fuller, 2005), the results of this study indicate that teen magazines include contradictory messages by emphasizing the image of "innocence", on one hand, while promoting birth control pills as a solution for acne, weight gain and menstrual pain, on the other hand. Chow (2004) reports that adolescents receive contradictory messages which suggest they should be erotically appealing, but without engaging in sexual activities. The focus group findings indicate that this type of conflicting information can lead to confusion for a teenager who was raised with more conservative values.

Focus group members mentioned that by reading girls' magazines, which continually present traditional, stereotypical gender roles and present frequent interviews and news about celebrities, girls are encouraged to think only about professions such as those of pop stars, movie stars, and fashion models. However, focus group findings indicate that girls do not want to be recognized merely by their body because they think that is a "shallow" image for a girl. Girls who took part in this study think that girls" magazines provide very few articles and no sections on vocational counselling which could help them choose a profession. It is reported that adolescents need advice and counselling about their personality, capabilities and possible areas of interest 
(Kulaksizoglu, 2007). This guides them to make healthy decisions on possible suitable professions.

In conclusion, this research indicates that teen magazines are used as one reference point by teenagers in North Cyprus in defining ideal beauty, and Turkish Cypriot girls are under the influence of the ideal Western beauty image promoted through these magazines. Also, girls buying these magazines are under continuous pressure for buying the products that are advertised or presented in the magazines. However, since girls also consume other types of media like music channels and web sites, it is difficult to state that teens may have developed their western ideals of beauty or consumption habits solely from those magazines. In addition, it should be noted that the owners of music channels in Turkey also own girls magazines (such as Hey Girl and Dream TV, Cosmo Girl and MTV), so similar messages and editorial policies are expected.

All in all, it should be noted that teen magazines are an influential type of media for girls. Consequently, this study has found evidence that girls are affected by the direct and indirect messages in teen magazines. Most of those messages seem to be on beauty and fashion products. Considering that teenagers are loyal to magazines, teen magazines should include more messages on healthy nutrition, information on professions for their inclusion into social life, non-shallow information on sexual issues, and non-conflicting messages.

\subsection{Suggestions for Further Study}

It has been reported in the content analysis part of this study that an issue of Seventeen, USA and CosmoGirl, Turkey have a lot matching and sometimes exact contents and articles. Starting from this observation, for future work, teen magazines published in 
Turkish can be compared with magazines published in USA and Europe to find similarities and differences in contents.

Considering that teenagers are now using the Internet heavily, their usage of web sites of magazines and other types of new media such as those promoting fashion products, beauty products, discussing make-up techniques should also be investigated in addition to magazines, to determine their impact on effects discussed in this study. For instance, a content analysis on the web pages of teen magazines can be performed.

Also, the impacts of television shows and programs and the impacts of social media on girls' perception of ideal beauty and their consumption behaviour in regard to cosmetics and fashion brands with direct and indirect messages can be compared to find similarities and differences.

The focus group study can be repeated for the Turkish teenage girls and its results can be compared with the results of this study.

Improving the questionnaire developed for this study (Appendix A), an enhanced scale for measuring magazine effects can be developed.

Another follow-up study can be interviewing the editors of the teen magazines to find out about their editorial policies and the reasons for the current format of content choices. 
For researchers that would like to conduct similar studies, I suggest employing some qualitative research techniques in addition to quantitative techniques, as adolescent girls may be opting for ideal answers in survey methods although they speak more frankly about their personal opinion during the focus group studies. 


\section{REFERENCES}

Akany1ldı, R. Ç. (2010). Perfect bodies, ideal women: beauty, the female body and the construction of femininity in popular women's magazines in Turkey in the 1990s. (Unpublished MA thesis), Boğaziçi University, Turkey.

Alemdar, K., Erdogan, I. (1994). Popüler kültür ve iletişim. Ümit Yayıncılık, Ankara, Turkey.

Archer, S. (1993). Identity status in early and middle adolescents: Scoring criteria. Chapter 8 in Marcia et al. (Eds.). Ego identity: A handbook for psychosocial research, Springer-Verlag.

Atik, D. \& Örten, T. (2008). İdeal beden imgesini oluşturan sosyal ve kurumsal faktörler ve bu idealin bireyler üzerindeki etkileri. Journal of Hacettepe University Faculty of Letters, 25(1), 17-35.

Aydoğan F. (2004). Medya ve popüler kültür üzerine yazllar. Media Cat Akademi, Istanbul, Turkey.

Ballentine, L. W., \& Ogle, J. P. (2005). The making and unmaking of body problems in Seventeen magazine, 1992-2003. Family \& Consumer Sciences Research Journal, 33, 281-307. http://doi.org/d2fmnr 
Baran, S. J. \& Davis, D. K., (2003). Mass communication theory, foundations, ferment, and future, $3^{\text {rd }}$ edition. (pp. 322-333), Thomson-Wadsworth.

Baron, R. A., Byrne D., \& Johnson B.T. (1998). Exploring social psychology, $\quad 4^{\text {th }}$ edition. Allyn and Bacon, USA.

Batmaz, V. (1986). Bir kitle iletişim aracı olarak televizyonun siyasal ve toplumsal etkileri: Ampirik bir model denemesi. (Unpublished doctoral dissertation), Ankara University, Turkey.

Behcetoğulları P., (2008). Anksiyetik/endișeli cins: Bağla beni! Toplumsal/yaralı cinsiyet(ler)e dair “Ordan burdan”, Kıbrls Yazılarl, Issue 10-11-12, 117-120.

Berger, A. A. (1991). Media analysis techniques. Sage, USA.

Berger, A. A. (2011). Media and communication research methods: An introduction to qualitative and quantitative approaches, $2^{\text {nd }} e d$. , Sage, USA.

Bloor, M., Frankland, J., Thomas, M., \& Robson, K. (2000). Focus groups in social research. London, UK: Sage.

Bordo, S. (1993). Unbearable weight: Feminism, western culture and the body, Berkeley, Univ. of California Press, USA. 
Bovet, J., Raymond, M. (2015). Preferred women's waist-to-hip ratio variation over the last 2,500 years. PLOS ONE, 10(4), 1-13. doi:10.1371/journal.pone.0123284

Bucchianeri, M. M., Arikian, A. J., Hannan, P. J., Eisenberg, M. E., \& Neumark Sztainer, D. (2013). Body dissatisfaction from adolescence to young adulthood: Findings from a 10-year longitudinal study. Body Image, 10, 1-7. http://doi.org/bx48

Ceulemans M., \& Fauconnier G. (1979). Mass media: The image, role, and social conditions of women: A collection and analysis of research materials. UNESCO report, Paris, France. Downloaded from http:// dergipark.ulakbim.gov.tr/intwojde/article/download/5000135149/5000123951

Chen, H., \& Jackson, T. (2012). Gender and age group differences in mass media and interpersonal influences on body dissatisfaction among Chinese adolescents. Sex Roles, 66, 3-20. http://doi.org/fmk5hk

Chow, J. (2004). Adolescents' perceptions of popular teen magazines. Journal of Advanced Nursing, 48 (2), 132-139. doi: 10.1111/j.1365-2648.2004.03180.x

Clark, Z., (2008). The bird that came out of the cage: A Foucauldian feminist approach to Kate Chopin's the Awakening. Journal for Cultural Research, (12)4, 335-347. 
Cole, T. J., Flegal, K. M., Nicholls, D., \& Jackson, A. A. (2007). Body mass index cut offs to define thinness in children and adolescents: International survey. British Medical Journal, 335, 194-197. http://doi.org/cj9xdx

Coleman R. (2008). The becoming of bodies. Feminist Media Studies, 8(2), 163-179. http://dx.doi.org/10.1080/14680770801980547

Colins, R. L., (2011). Content analysis of gender roles in the media: Where are we now and where should we go? Sex Roles, No. 64, 290-298.

Cook, D. T. (2008). The missing child in consumption theory. Journal of Consumer Culture, 8, 219-243. http://doi.org/bgss2s

Cornett, A. M. (2012). Examining the effects of men's magazines on men's perceptions of women through cultivation theory. (Unpublished MS thesis), University of Kansas, USA.

Crawford M., Unger R., (2000). Women and gender: A feminist psychology. McGraw-Hill, USA.

Crawford, M., et al., (2008), Globalizing beauty: Attitudes toward beauty pageants among Nepali women. Feminism Psychology, 18, p. 61. 
Crossley, K. L., Cornelissen P. L. \& Tovee, M. J. (2012). What is an attractive body? Using an interactive $3 \mathrm{D}$ program to create the ideal body for you and your partner. PLOS ONE, 7(11), 1-11. doi:10.1371/journal.pone.0050601

Çakır, S. (2007, September 16). Osmanlı kadın hareketi. Açık Gazete, http://www.acikgazete.com/?newsid=17546\&category=106 retrieved from the Internet on 24 September 2007.

Dağtaş, E. (2003). Türkiye'de Magazin Basını, Ütopya Yayınevi, Ankara.

Darga, A. M. (2011). Anadolu’da kadın. Yapı Kredi Yayınları, İstanbul.

Darling-Wolf, F. (2004). Sites of attractiveness: Japanese women and Westernized representations of feminine beauty. Critical Studies in Media Communication, 21(4), 325-345.

Davalos et al., (2007). Content analysis of magazine headlines: Changes over three decades. Feminism \& Psychology, 17(2), 250-258.

Davis, K. (2000). Beauty: The feminine beauty system. In L.Code (Ed.), Encyclopedia of Feminist Theories (pp. 38-39), London: Routledge.

de La Ville, V. I. (2007). The consequences and contradictions of child and teen consumption in contemporary practice. Society and Business Review, 2, 7-14. http://doi.org/b4gd7b 
Dow, B. J., Condit, C. M. (2005). The state of the art in feminist scholarship in communication. Journal of Communication, (September), 448-478.

Duits, L. (2010) .The importance of popular media in everyday girl culture. European Journal of Communication, 25, 243-257. http://doi.org/fjfbjk

Duke, L. L., \& Kreshel, P. J. (1998). Negotiating femininity: Girls in early adolescence read teen magazines. Journal of Communication Inquiry, 22, 48-71. http://doi.org/fb699c

Duke, L. L. (2000). The role of age and race in adolescent girls' interpretations of teen magazines. (Unpublished doctoral dissertation), University of Georgia, USA.

Durham M. G. (1998). Dilemmas of desire: representations of adolescent sexuality in two teen magazines. Youth and Society, 29 (3), 369-390.

Eksi, H. (2001). Başa çıkma, dini başa çıkma ve ruh sağlı̆̆ı arasındaki ilişki üzerine bir araştırma. ("Coping: A study on the relationship between religious coping and mental health") (Unpublished doctoral dissertation), Uludağ University, Bursa, Turkey.

Evans, E. D., Rutberg, J., Sather, C., \& Turner, C. (1991). Content analysis of contemporary teen magazines for adolescent females. Youth \& Society, 23, 99120. http://doi.org/bcr8b6 
Featherstone, M. (1996). Localism, Globalism and Cultural Identity. In ed. R. Wilson and W. Dissanayake, Global/local. Duke University Press, p. 47.

Felski, R. (2006). Because it is beautiful: New feminist perspectives on beauty. Feminist Theory, 7 (2), 273-282.

Fowler Jr, F. J. (2014). Survey research methods. Sage Publications, London.

Fuller, C. (2005). A content analysis of seventeen magazine and the messages its articles and advertisements are sending to teenage girls. (Senior Research Project, Paper 37), Southern Adventist University, USA. http://knowledge.e.southern.edu/senior_research/37

Friedan B. (2013). The feminist mystique. W.W. Norton and Company, USA.

Frith, H., \& Gleeson, K. (2004). Clothing and embodiment: Men managing body image and appearance. Psychology of Men \& Masculinity, 5, 40-48. http://doi.org/bx898d

Gane, M. (2007). Changing cultural symbols of femininity: An investigation of products advertised in Seventeen magazine, 1945 to 2005. Proceedings of the annual meeting of the American Sociological Association, New York, NY.

Retrieved from: http://bit.ly/2jG3lg0 
Garner, A., Sterk H. M., Adams S. (1998). Narrative analysis of sexual etiquette in teenage magazines. Journal of Communications, (Autumn), 59-78.

Gerbner, G. (1992). Violence and Terror by the Media. In M. Raboy and B. Dagenars (Eds.). Media, crisis and democracy. Sage, 94-107.

Gerbner, G. (1994). The politics of media violence: some reflections. In Cees J. Hamelink, C. J. \& Linne, O. (Eds.), Mass communication research: Problems and policies, the art of asking the right question. Ablex Publishing Corporation, Norwood, New Jersey, USA.

http://web.asc.upenn.edu/gerbner/Asset.aspx?assetID=1602

Gerbner, G. (1998). Cultivation analysis: An overview. Mass Communication and Society, 1:3-4, 175-194, doi: 10.1080/15205436.1998.9677855

Gerbner, G. (1999). The stories we tell. Peace Review, 11, 9-15. http://doi.org/c553sp

Gerbner, G., et.al. (2002). Growing up with television: The cultivation perspective. In J. Bryant \& D. Zillmann (eds.), Media effects, advances in theory and research. Lawrence Erlbaum, 43-68.

Godey's Ladies Book, (February 1656). The night before the wedding. http://www.uvm.edu/ hag/godey/contents.html

Godey's Ladies Book, (November 1857). The governess 
http://www.uvm.edu/ hag/godey/contents.html

Gonick, M. (1996) Teen magazines and feminist pedagogy, Canadian Dimension. $30(5), 27-29$.

Gonick, M. (1997). Reading selves, re-fashioning identity: Teen magazines and their readers. Curriculum Studies, 5, 69-86. http://doi.org/bgxpjs

Gonick, M. (2003). Between femininities: Ambivalence, identity, and the education of girls. State University of New York Press, 2003.

Gordon, M.K. (2004). Media images of women and African American girls'sense of self. (Unpublished doctoral dissertation), University of Michigan, USA.

Grogan, S. \& Wainwright, N. (1996). Growing up in the culture of slenderness: Girls' experiences of body dissatisfaction. Women's Studies International Forum, 19 (6), 665-673. https://doi.org/10.1016/S0277-5395(96)00076-3

Gross, L. P. (1997). Television as a Trojan horse, School Media Quarterly, 175-180.

Grudens-Schuck, N. Allen, B. L. \& Larson, K. (2004). Focus Group Fundamentals. Iowa State University Digital Repository. http://www.extension.iastate.edu/Publications/PM1969B.pdf retrieved from the Internet on: 22/03/2006. 
Güngör, N. (1999). Popüler kültür ve iktidar. Vadi Yayınları, Ankara, Turkey.

Güngör, N. (2013). İletişim: Kuramlar, yaklaşımlar. Siyasal kitabevi, Ankara, Turkey.

Hall, S. (2001). Encoding/Decoding. Chapter 11 in M.G. Durham and D.M. Kellner (Eds.). Media and cultural studies. Oxford: Blackwell, UK.

Hansen, A., Cottle, S., Negrine, R. \& Newbold, C. (1998). Mass communication research methods, NYU Press, USA.

Hendriks, A. \& Burgoon, M. (2003). The relationship between fashion magazine consumption and body satisfaction in women: Who is most at risk of influence? Proceedings of the Meeting of the International Communication Association, San Diego, CA, USA.

Hermes J. (1995). Reading women's magazines: An analysis of everyday media use, Polity Press, USA.

Hey Girl Magazine (2007). http://www.emecmua.com/YayinDetay.aspx?DID=66 , retrieved from the Internet on 12/09/2007

Hooks, B. (1993). Black Looks: Race and Representation, South End Press, Boston, USA. 
İnceoğlu, Y. \& Kar, A. (2009). New beauty icons: Freedom or conviction to the human body, Proceedings of the Media and Healthy Development in Adolescence Conference, 7-31, Hong-Kong, China.

Johnson, R. B., Onwuegbuzie, A. J., Turner, L. A. (2007). Toward a definition of mixed methods research. Journal of Mixed Methods Research, 1 (2), 112-133. http://doi.org/10.1177/155868980629824

Jones, D. C., Vigfusdottir, T. H., Lee, Y. (2004). Body image and the appearance culture among adolescent girls and boys: An examination of friends, conversations, peer criticism, appearance magazines, and the internationalization of appearance ideals. Journal of Adolescent Research, 19, $323-339$.

Kara, N. (2000). Feminist kadın hareketleri ve medya profesonellerinin tutumlart. (unpublished doctoral dissertation), Ankara University, Turkey.

Kehily, M. J. (1999). More sugar? Teenage magazines, gender displays and sexual learning. European Journal of Cultural Studies, 2 (1), 65-89.

Kirca S. (2001). Turkish women's magazines: The popular meets the political, Women's Studies International Forum, (3-4), 457-468.

Kilbourne, J. (2014, May 8). The dangerous ways ads see women, TEDx Lafayette College, https://www.youtube.com/watch?v=Uy8yLaoWybk 
Kim, J. L., \& Ward, L. M. (2004). Pleasure reading: Associations between young women's sexual attitudes and their reading of contemporary women's magazines. Psychology of Women Quarterly, 28, 48-58. http://doi.org/fbf6jz

Kim, K. et al. (2011). Socialization and the teen magazines: What are the messages? International Journal of Costume and Fashion, 11 (2), 1-12.

Knauss, C., Paxton, S. J., \& Alsaker, F. D. (2007). Relationships amongst body dissatisfaction, internalisation of the media body ideal and perceived pressure from media in adolescent girls and boys. Body Image, 4, 353-360. http://doi.org/bqgs7v

Kroger, J. (1997). Gender and Identity: The Intersection of Structure, Content, and Context. Sex Roles, 36 (11), 747-768. doi:10.1023/A:1025627206676

Kula Demir, N. (2004). Genç kız dergilerinin söylemsel çözümlemesi: İktidar, ideoloji ve kimlik [Discourse analysis of two magazines intended for young girls]. Kadın/Woman 2000 - Journal for Women's Studies, 5, 93-116.

Kulaksızoğlu, A. (2007). Ergenlik psikolojisi [Adolescent psychology]. Remzi Kitabevi, Istanbul, Turkey.

Labre M. P. \& Walsh-Childers K. (2003). Friendly advice? Beauty messages in web sites of teen magazines. Mass Communication and Society, 6(4), 379-396. 
Magazine Publishers of America. (2004). Teen Market Profile. http://www.magazine.org, retrieved from Internet 12/02/2005

Marcia, J. E. (1966). Development and validation of ego-identity status. Journal of Personality and Social Psychology, $3 \quad$ (5), 551-558. http://dx.doi.org/10.1037/h0023281

Martin, M. C., \& Peters, C. O. (2005). Exploring adolescent girls' identification of beauty types through consumer collages. Journal of Fashion Marketing and Management: An International Journal, 9(4), 391-406. http://doi.org/cktzqb

Massoni, K. (2011). Fashioning teenagers: A cultural history of Seventeen magazine, Left Coast Press, USA.

McLuhan, M. (2006). The Medium is the Message. Chapter 8 in Durham, M.G. and Kellner, D.M. (Eds.), Media and cultural studies: Key works, Blackwell, USA.

McPherson, K. (2003). First Wave/Second Wave Feminism. In Code, L. (Ed.), Encyclopedia of Feminist Theories (p. 208). London: Routledge.

McQuail, D. (2005). McQuail's Mass Communication Theory, $5^{\text {th }}$ edition. Sage.

McQuail, D. (2013). Reflections on Paradigm Change in Communication Theory and Research. International Journal of Communication, 7, 216-229. 
McRobbie, A. (1991). Feminism and youth culture, Macmillan Education, UK.

McRobbie, A. (1993), "Jackie: An ideology of adolescent femininity”, in Waites, B., Bennet, T., and Martin, G. (Eds.), Popular Culture: Past and Present, Oxford University Press and Routledge, London.

McRobbie, A. (1994). Postmodernism and popular culture, Routledge, UK.

McRobbie, A. (1997). Back to reality? Social experience and cultural studies. Manchester University Press, UK.

Meenakshi, D. (2005) Myths of race and beauty in teen magazines: A semiological analysis. The Annual Meeting of the International Communication Association, NY. http://www.allacademic.com/meta/p14312_index.html

Meyers, M. (1999). Fracturing women. Chapter 1 in Meyers, M. (Ed.), Mediated women, Hampton Press Inc., USA.

Milestone, K. \& Meyer A. (2012). Gender and popular culture. Polity Press, UK.

Morgan, D. L. (1996). Focus groups. Annual Review of Sociology, 22, 129-152. http://doi.org/bjen8d

Morgan, D. L. (1997). The focus group guidebook. Sage Publications, USA. 
Morgan, M. \& Shanahan, J. (2010). The state of cultivation. Journal of Broadcasting \& Electronic Media, 54(2), 337-355.

MRI Teenmark (2003), Teen products data.

http://www.magazine.org/content/files/teenproducts.xls , retrieved from internet on 15/03/2004

Mulvey, L. (1989). Visual pleasure and narrative cinema. In Visual and other pleasures, Palgrave Macmillan UK. http://dx.doi.org/10.1007/978-1-349-19798-9_3

Mutlu, E. (1998). Iletişim sözlüğü (Dictionary of communication), Bilim ve Sanat Yayınları, Ankara, Turkey.

Nailer, D. (2011). Representation of women in advertisements: A semiotic analysis of women in North Cyprus life style magazines. (Unpublished MA thesis), Eastern Mediterranean University, North Cyprus.

Nam, K., Lee, G., \& Hwang, J. S. (2011). Gender stereotypes depicted by Western and Korean advertising models in Korean adolescent girls' magazines. Sex Roles, 64, 223-237. http://doi.org/fjmbcn

Nash, K. (2002). Liberal feminism. In L. Code (Ed.), Encyclopedia of Feminist Theories (pp. 303-305), London: Routledge. 
Nielsen Co. (2009). Americans watching more TV than ever. Retrieved from: http://www.nielsen.com/us/en/insights/news/2009/americans-watching-moretv-than-ever.html

Oktay A. (1993). Türkiye'de popüler kültür. Cogito-Yapı Kredi Yayınları, İstanbul, Turkey.

Opree, S. J., Buijzen, M., van Reijmersdal, E. A., \& Valkenburg, P. M. (2014). Children's advertising exposure, advertised product desire, and materialism: A longitudinal study. Communication Research, 41, 1-19. http://doi.org/bx49

Özbek, M. (2003). Popüler kültür ve Orhan Gencebay arabeski. İletişim Yayınları. (First printed in 1991).

Özer, Ö. (2004). Yetiştirme kuramı: Televizyonun kültürel işlevlerinin incelenmesi, published doctoral dissertation, Anadolu Üniversitesi Yayınları, No. 1578, Turkey.

Özer, Ö. (2005). Yetiştirme kuramı: Televizyonla yaşamanın ideolojik kültürel sonuçlarına yönelik yapılan araştırma. Sosyal Bilimler Dergisi, (1), 75-107.

Özgür, F., Tuncali, D., \& Güler Gürsu, K. (1998). Life satisfaction, self-esteem, and body image: A psychosocial evaluation of aesthetic and reconstructive surgery candidates. Aesthetic Plastic Surgery. 22 (6), 412-419. 
Öztürk, S. (2000). Televizyonun çocukların siyasal toplumsallaşmalarındaki yeri. (unpublished masters thesis), Gazi University, Turkey.

Pardun, C. J., L'Engle, K. L. \& Brown, J. D. (2005). Linking exposure to outcomes: early adolescents' consumption of sexual content in six media, Mass Communication and Society, 8 (2), 75-91.

Parker, A., \& Tritter, J. (2006). Focus group method and methodology: Current practice and recent debate. International Journal of Research \& Method in Education, 29, 23-37. http://doi.org/bndh3m

Peirce, K. (1993). Socialization of teenage girls through teen-magazine fiction: the making of a new woman or an old lady? Sex Roles, 29 (1-2), 59-69.

Petersen, A. (2000). Identity, In Code, L. (Ed.) Encyclopedia of Feminist Theories, (p.262). Routledge, London, UK.

Plunkett, J. (2011, January 24). Magazines suffer the impact of free media and blame the teenagers. The Guardian, UK. Retrieved from the Internet at: https://www.theguardian.com/media/2011/jan/24/magazines-free-medialaunches

Purdy, E. (2005). Encyclopedia of politics: The left and the right. Carlisle, L. P. (Ed.) (In Volume 1: The left, p. 161). 
Radway, J. A. (1991). Reading the romance: Women, patriarchy, and popular literature. The University of North Carolina Press, Chapel Hill, USA.

Reimer, B. \& Rosengren, K. E. (1990) Cultivated viewers and readers: A life-style perspective, in Signorielli, N. \& Morgan, M. (Eds.), Cultivation analysis: New directions in media effects research, 181-206, Sage Publications, California, USA.

Research and Markets (2013). Teenage \& pre-teen magazines market update: 2013. http://www.businesswire.com/news/home/20140102005297/en/ResearchMarkets-Teenage-Pre-Teen-Magazines-Market-Update .

Roger, S. (1997). Medya, kültür siyaset, imgeler ve eşitlik: Kadınlar ve ulusal basın”, Derleyen: Süleyman İrvan, Ankara, Turkey.

Rowe, I., \& Marcia, J. E. (1980). Ego identity status, formal operations, and moral development. Journal of Youth and Adolescence, 9 (2), 87-99. doi: 10.1007/BF02087928.

Sauer, H., \& Robles-Piña, R. (2003). Magazines: What adolescent girls are reading and the way they shape body image. Advancing Women in Leadership Journal, (Fall), 1-10. 
Schlenker, J. A., Caron, S. L. \& Halteman, W. H. (1998). A feminist analysis of seventeen magazine: Content analysis from 1945 to 1995. Sex Roles, 38, $(1 / 2), 135-149$.

Seid, R. P. (1994). Too "close to the bone": The historical context for women's obsession with slenderness. Chapter 1 in Fallon, P., Katzman, M. A., Wooley S. C. (Eds.), Feminist perspective on eating disorders, Guilford Press, New York.

Seneca, T. (1994). The history of women's magazines: magazines as virtual communities. New York University, LIS 282B Report for History of Printing and Publishing 1700-Today. retrieved from: http://besser.tsoa.nyu.edu/impact/f93/students/tracy/tracy hist.html

Shaffer, D. R. (2002). Developmental Psychology, Wadsworth, USA.

Shields V. \& Mayhow K. (2001). Face value: how US female identity is produced in/through/against fashion ads. In Mediated identities. Ross K.et al. (Eds.), Istanbul Bilgi University Press,

Signorielli, N. \& Morgan, M. (1996). Cultivation analysis: Research and practice. Chapter 8 in Stacks, D. W., Salwen, M. B. (Eds.) An Integrated Approach to Communication Theory and Research, Lawrence Erlbaum, USA.

Signorielli, N. (1997). Reflections of girls in the media: A content analysis: A study of television shows and commercials, movies, music videos, and 
teen magazine articles and ads. Research Report. http://files.eric.ed.gov/fulltext/ED444214.pdf

Silvestre, M. J. C. (2009). Female body representations in Portuguese popular media. In N. Kara (Ed.), Gender at the crossroads: Multi-disciplinary perspectives. (pp. 315-322).Eastern Mediterranean University Press, Famagusta, Northern Cyprus.

Smolak, L., Levine M. P. \& Thompson J. K. (2001). The use of the socio-cultural attitudes towards appearance questionnaire with middle school boys and girls. International Journal of Eating Disorders, 29, 216-223.

Starr, C. (2003). Third-wave Feminism. Code, L. (Ed.), Encyclopedia of Feminist Theories, (p. 474), Routledge, London, UK.

Steele, J. R., Brown, J. D. (1995). Adolescent room culture: Studying media in the context of everyday life. Journal of Youth and Adolescence, 24, 551-576. doi :10.1007/BF01537056

Taylan, H. H. (2011). Televizyon programlarındaki şiddetin yetiştirme etkisi: Konya lise öğrencileri üzerine bir araştırma, Selçuk Üniversitesi Sosyal Bilimler Enstitüsü Dergisi, 26, 355-367.

Tezbaşaran, A. (2008). Likert tipi ölçek hazırlama kılavuzu. Türk Psikologlar Derneği Yayını. Mersin, Turkey . 
Thom, D. (2002). Socialism and feminism. In L.Code (Ed.), Encyclopedia of Feminist Theories (pp. 452-453), London: Routledge.

Tiggemann, M., Gardiner, M., \& Slater, A. (2000). I would rather be size 10 than have straight A's: A focus group study of adolescent girls' wish to be thinner. Journal of Adolescence, 23, 645-659. http://doi.org/b5shpt

Tiggemann, M. (2003). Media exposure, body dissatisfaction and disordered eating: Television and magazines are not the same! European Eating Disorders Review, 11, 418-430. http://doi.org/c5bpwg

Tiggemann, M. (2012). Sociocultural perspectives on human appearance and body image. In Cash T. F. and Smolak,L. (Eds.) Body image: A handbook of science, practice and prevention, $2^{\text {nd }}$ ed., Guilford Press, New York, USA.

Tornblom, H. (2006). A feminist investigation: Objectification and well-being. Ecclectica, April. http://ecclectica.brandonu.ca/issues/2006/1/Article-28.html

Trimble-Clark, B. (2012). A Feminist Content Analysis of Seventeen Magazine. (Unpublished MA thesis). Minnesota State University, Mankato, USA.

$\mathrm{Tu}, \mathrm{C} . \mathrm{T}$. (2007). The relationship between exposure to thin models in fashion magazines and Taiwanese female readers' perceptions of their body shapes. (Unpublished doctoral dissertation). Hawaii Pacific University, USA. 
Tyre, P. (2004, April 19). No longer most likely to succeed: In an overcrowded market, teen magazines fight for their lives. Newsweek, 59.

van Zoonen, L. (1994). Spectatorship and the gaze. Chapter 6 in Feminist Media Studies, Sage, London, UK.

Vares T., Jackson S. (2010). Preteen girls read 'Tween' popular culture: A contribution to the "sexualization of girlhood debates". Proceedings of the $4^{\text {th }}$ Child and Media Consumption Conference, Norrköping, Sweden.

Voelker, D. K., Reel, J. J., \& Greenleaf, C. (2015). Weight status and body image perceptions in adolescents: Current perspectives. Adolescent Health, Medicine and Therapeutics, 6, 149-158. http://doi.org/bx5b

Vonderen K. E. V. \& Kinnally W. (2012). Media effects on body image: Examining media exposure in the broader context of internal and other social factors. American Communication Journal. 14 (2), 41-57.

Walsh, L. M. \& Ward, L. M. (2010). Magazine reading and involvement and young adults' sexual health knowledge, efficacy, and behaviors. The Journal of Sex Research, 47 (4), 285-300. http://dx.doi.org/10.1080/00224490902916009

Willemsen, T. M. (1998). Widening the gender gap: teenage magazines for girls and boys, Sex Roles, 38 (9), 851-861. 
Williams, K. (2003). Understanding media theory, Arnold-Oxford University Press, London, UK.

Willis, E. (1984). Radical Feminism and Feminist Radicalism. Social Text, The 60's without Apology (9/10), 91-118.

Witkin, R. W. (2003). Adorno on popular culture, Routledge, UK,

Wolf, N. (1991). The beauty myth: How images of beauty are used against women. Harper Collins, New York, USA.

Xu G. \& Feiner S. (2007). Meuni Jingji / China's beauty economy: Buying looks, shifting value and changing place. Feminist Economics, 13 (3-4), 307-323.

Yapar, A. (1999). Fransa ve Türkiye'de dergicilik olgusu, (Unpublished doctoral dissertation), Istanbul University, Turkey.

Yumlu, K. (1987). Kitle kültürü oluşumunda televizyonun rolü, (Unpublished doctoral dissertation), Dokuz Eylül University, Turkey.

Zhang W. \& Chia S. C. (2006). The effects of mass media use and social capital on civic and political participation. Communication Studies, 57 (3), 277-297.

Zollo, P. (1995). Talking to teens. American Demographics, 17 (November), $22-28$. 


\section{APPENDICES}




\section{Appendix A: Questionnaire}

\section{MAGAZIN DERGILERININ ETKILLERININ ARAŞTIRILMASI}

Değerli gençler, araştırmanın sağlıklı olabilmesi için vereceğiniz samimi yanıtların önemi büyüktür. Verdiğiniz yanıtlar gizli tutulacak, sadece araştırmacı tarafından değerlendirilecektir. Katkılarınız için teşekkür ederim.

\section{Sorular}

1. Kaç yaşındasınız?
a. 12
b.13 c. 14
d.15 e.16
f. 17

2. Her istediğinizde anne ya da babanızdan harçlık alabilir misiniz?

a. Evet b. Hayır

3. Haftalık ortalama harçlığınız ne kadardır? ( hafta sonu dahil)

a. 25 YTL'den az b.25 -50 YTL c.50-75 YTL d.75-100 e. 100'den fazla

4. Annenizin eğitim düzeyi nedir?

a. İlkokul b.Ortaokul c.Lise d.Üniversite e.Lisansüstü f.

Diğer

5. Babanızın eğitim düzeyi nedir?

a. İlkokul b.Ortaokul c.Lise d.Üniversite e.Lisansüstü f.

Diğer

6. Süpermarketlerden aileniz için yiyecek-içecek alışverişi yapar mısınız?
a. Evet
b. Hayır

7. Kendinize ait bir banka kartınız var mı?

a. Evet b. Hayır

8. Kendinize ait bir cep telefonunuz var mı?

a. Evet b. Hayır

9. Var ise elinizdeki kaçıncı cep telefonunuz?
a. Ilk
b. Ikinci
c. Üçüncü
d. Dördüncü
e. Diğer (Lütfen belirtiniz)

10. Ortalama ne kadar sürede telefonunuzu değiştirirsiniz?
a.1-3 ay
b.4-6ay
c. 6-9 ay
d. 10-12 ay
e. Diğer (Lütfen
belirtiniz)

11. Evinizde İnternet bağlantısı var mı?

a. Evet b. Hayır

12. Evinizde uydu TV alıcısı var mı?

a. Evet b. Hayır 
13. Var ise en çok izlediğiniz müzik kanalları hangileridir?
a. MTV
b. Kral TV
c. VH1
d. Number1 TV
e. Power Türk
f. Dream TV
g. Diğer (Lütfen belirtiniz)

14. Harçlıklarınızı en çok ne almak için kullanırsınız?

a. Yiyecek b. Giysi c. Aksesuar d. Güzellik malzemesi e. Kitap f. Dergi g. Diğer

15. Yakın bir gelecekte ne almayı planlıyorsunuz? (lüttfen marka/cins belirtiniz)

a. Cep telefonu d. Giysi

b. I-pod/MP3 çalar

e. Güzellik

malzemesi

c. Bilgisayar

f. Aksesuar

g. Kitap

h. Diğer ( lütfen

belirtiniz)

16. Sizin için marka önemli midir?

a) Evet önemlidir, çünkü

b) Hayır önemli değildir, çünkü

17. Boyum (lütfen belirtiniz)

Kilom (lütfen belirtiniz)

18. Hiç kilo vermek için rejim yaptınız mı?
a) Evet
b) Hayır

19. Şu anda kilo vermek için rejimde misiniz?
a) Evet
b) Hayır

20. Yakın gelecekte kilo vermek amacı ile rejim yapmayı düşünüyor musunuz?
a) Evet
b) Hayır

21. Sizce bir genç kızı en güzel gösteren saç rengi hangisidir?
a) Kendi doğal rengi
b) Sar1
c) Kahve rengi
d) Siyah
e)

Kizıl

f) Diğer (Lütfen belirtiniz)

22. Sizce bir genç kızı en güzel gösteren göz rengi hangisidir?
a) Kendi doğal rengi
b) Yeşil
c) Mavi
d) Kahve
e) Diğer

23. Düzenli olarak bir ya da daha çok gençlik dergisi satın alır mısınız?
a) Evet alırım
b) Bazen alırım
c) Sadece Internet'ten okurum
d) Hiç almam 
24. 23. Soruya cevabınız (d) ise hiç almama nedeniniz nedir?

a) Almam çünkü ilgimi çekmiyor

b) Almam çünkü çok pahalı

c) Almam, başkalarının aldığını okurum

d) Gençlik dergisi yerine yetişkinler için olanları alırım (Cosmopolitan, Hülya $\mathrm{vb})$.

e) Almam çünkü

25. 23. Soruya cevabınız Evet ya da Bazen ise hangi dergiyi/dergileri alıyorsunuz? (Birden fazla seçenek işaretleyebilirsiniz)
a) Hey Girl
b) Cosmo Girl
c) Go Girl
d) Salsa
e) Diğer

26. Dergileri ailemin bilgisi dahilinde alırım.
a) Evet
b) Hayır

27. Dergileri nasıl bir ortamda okumayı tercih edersiniz?
a) Odamda yalnız
b) Arkadaşlarımla birlikte
c) Evimizin oturma odasında
d)Diğer

28. En çok beğendiğiniz gençlik dergisi hangisidir?
a) Hey Girl
b) Cosmo Girl
c) Go Girl
d) Salsa
e) Diğer
f)Hiçbiri

29. Son bir hafta içinde bir gençlik dergisi okudunuz mu?
a) Evet
b) Hayır

30. Magazin dergilerini alırken sizin için neler belirleyici olur?
a) Kapaktaki resim
b) Derginin verdiği hediyeler
c) İçindeki konular

d) Diğer

31. Kendinize birşey alırken (giysi, aksesuar, cep telefonu vs.) kimler / neler etkili olur?

a) Dergilerdeki reklamlar

b) Arkadaşlarım ya da benim yaşımdakiler

c) Aile üyeleri (lütfen kim olduğunu belirtiniz).

d) Diğer ( lütfen belirtiniz)

32. Gençlik dergilerinde en çok beğendiğiniz bölümler hangileridir? Lütfen önem sırasına göre 1 den 10 a doğru bir değer veriniz.

( )Moda

( )Güzellik önerileri

( )Karşı cinsle ilgili öneriler

( )Alış veriş onerileri

( )Astroloji

( )Sanatc1lar ile röportaj

( )İçindeki reklamlar

( ) Testler

( )Okuyucu mektupları

( ) Diğer

( )Posterler 
33. Elbise dolabınızda en çok hangi kıyafetler bulunur? Lütfen çoktan aza doğru sıralayınız. ( örneğin en çok kot pantolon ise yanına 1, sonraki 2, sonraki 3 gibi )

a) Kot pantolon( ) b) Kot etek( ) c) Kumaş Pantolon( ) $\quad$ d) Kumaş etek( )
e) Tişört( )
f) Gömlek( )
g) Abiye ( )
h) Aksesuar( )

1) Diğer

Aşağıdaki magazin dergileri ile ilgili ifadelerden hangileri sizin için geçerlidir?

34. Giyimimi olumlu yönde etkiler
a. Kesinlikle katılırım
b. Katılırım
c. Kararsizim
d. Katılmam e.

Kesinlikle katılmam

35. Verdiği önerilerle arkadaşlarla olan ilişkilerimde bana yol gösterir
a. Kesinlikle katılırım
b. Katılırım
c. Kararsizim
d. Katılmam e.

Kesinlikle katılmam

36. Ailemle, okulumla olan ilişkilerimde bana yol gösterir
a. Kesinlikle katılırım
b. Katılırım
c. Kararsizim
d. Kat1lmam
e. Kesinlikle katılmam

37. Karşı cinsle olan ilişkilerimde bana yol gösterir
a. Kesinlikle katılırım
b. Katılırım
c. Kararsizim
d. Katılmam e. Kesinlikle katılmam

38. a Hoşça vakit geçirmemi sağlar, bana dertlerimi unutturur.
a. Kesinlikle katılırım
b. Katılırım
c. Kararsizim
d. Katılmam e. Kesinlikle katılmam

38. b Gençlik dergilerindeki mankenlere giydikleri ne kadar yakışıyorsa bana da giydiklerim o kadar yakışır.
a. Kesinlikle katılırım
b. Katılırım
c. Kararsizim
d. Katılmam e.

Kesinlikle katılmam

39. Annem ve/ veya kız kardeşlerim alış veriş yapacağı zaman benim onları doğru yönlendirmemde katkısı olur.
a. Kesinlikle katılırım
b. Katılırım
c. Kararsizim
d. Katılmam e.
Kesinlikle katılmam

40. Gençlik dergilerinin kapaklarında gördüğüm kızlar gibi görünmek isterim.
a. Kesinlikle katılırım
b. Katılırım
c. Kararsizım
d. Katılmam e.
Kesinlikle katılmam 
Aşağıdaki sorular bedeninizde beğendiğiniz yönlerin derecesi ile ilgilidir. Beden kısımlarınızla ilgili memnuniyet derecenizi aşağıdaki şıklara göre işaretleyiniz.
a) Çok memnunum b) Memnunum c) Kararsızım
d) Memnun değilim
e) Hiç memnun değilim

\begin{tabular}{|c|c|c|c|c|}
\hline 41. Saçlarımdan & a.( ) & b.( ) & c. ( ) & d.( ) \\
\hline 42. Kulaklarımdan & a.( ) & b. ( ) & c. ( ) & d. ( ) \\
\hline 43. Ă̆zım ve dudaklarımdan & a. ( ) & b.( ) & c. ( ) & d. ( ) \\
\hline 44. Çenemden & a.( ) & b. ( ) & c. ( ) & d. ( ) \\
\hline 45. Yüz güzelliğimden & a.( ) & b. ( ) & c. ( ) & d. ( ) \\
\hline 46. Omuzlarımdan & a.( ) & b. ( ) & c. ( ) & d. ( ) \\
\hline 47. Kollarımdan & a.( ) & b. ( ) & c. ( ) & d. ( ) \\
\hline 48. Belimden & a. ( ) & b. ( ) & c. ( ) & d.( ) \\
\hline 49. Ayaklarımdan & a.( ) & b. ( ) & c. ( ) & d. ( ) \\
\hline 50. Cildimin renginden & a. ( ) & b.( () & c.( () & d.( ) \\
\hline 51. Boyumdan & a.( ) & b. ( ) & c. ( ) & d. ( ) \\
\hline 52. Genel görünüşümden & a.( ) & b. ( ) & c. ( ) & d.( ) \\
\hline 53. Gözlerimden & a.( ) & b. ( ) & c. ( ) & d.( ) \\
\hline 54. Burnumdan & a.( ) & b. ( ) & c. ( ) & d.( ) \\
\hline 55. Dişlerimden & a.( ) & b. ( ) & c. ( ) & d. ( ) \\
\hline 56. Yüzümdeki sivilcelerden & a.( ) & b. ( ) & c. ( ) & d.( ) \\
\hline 57. Yüzümdeki tüylerden & a.( ) & b. ( ) & c. ( ) & d. ( ) \\
\hline 58. Sesimin tonundan & a.( () & b.( ) & c. ( ) & d. ( ) \\
\hline 59. Göğüslerimden & a.( ) & b. ( ) & c. ( ) & d. ( ) \\
\hline 60. Ellerimden & a.( ) & b. ( ) & c. ( ) & d. ( ) \\
\hline 61. Kalçalarımdan & a.( ) & b. ( ) & c. ( ) & d.( ) \\
\hline 62. Bacaklarımdan & a.( ) & b. ( ) & c. ( ) & d. ( ) \\
\hline 63. Vücut tüylerimden & a.( ) & b. ( ) & c. ( ) & d. ( ) \\
\hline 64. Kas yapımdan & a.( ) & b. ( ) & c. ( ) & d. ( ) \\
\hline 65. Kilomdan & a.( ) & b. ( ) & c. ( ) & d. ( ) \\
\hline
\end{tabular}

66. Devam ettiğiniz okul

67. Okul başarı durumunuz: $\quad$ a. Pekiyi $\quad$ b. İyi $\quad$ c. Orta $\quad$ d. Zayıf

Anketi yanıtladığınız için teşekkür ederim...

Yonca Aybay

Doğu Akdeniz Üniversitesi

İletişim Fakültesi, Doktora Öğrencisi

Tel: (392) 6301296 


\section{Appendix A: Questionnaire}

\section{A STUDY ON MAGAZINE EFFECTS}

Dear youngsters, in order for this study to be meaningful, your sincere answers carry great importance. Your answers will be kept strictly confidential and will only be used by the researcher. Thank you very much for your contribution

\section{Questions}

1. How old are you?
a. 12
b. 13 c. 14
d.15 e.16
f.17

2. Can you get allowance from your mother/father anytime you ask for it?

a. Yes b. No

3. What is your weekly average allowance? (including weekend)
a. less than 25 YTL
b. $25-50$ YTL
c.50-75 YTL
d.75-100 YTL
e. more than 100 YTL

4. What is your mother's education level?
a. Primary school
b. Secondary school
c. High school
d. University
e. Masters level
f. Other

5. What is your father's education level?
a. Primary school
b. Secondary school
c. High school
d. University
e. Masters level
f. Other

6. Do you shop for food and drinks from supermarkets for your family?

a. Yes b. No

7. Do you own an ATM card?

a. Yes b. No

8. Do you own a cell phone?

a. Yes b. No

9. If you own a cell phone, it is your ...
a. First
b. Second
c. Third
d. Fourth
e. Other (please indicate:

10. What is the average duration of changing your cell phone?
a. 1-3 months
b. 4-6 months
c. 6-9 months
d. 10-12 months
e. Other (please indicate:

11. Do you have Internet connection at home?
a. Yes
b. No

12. Do you have a satellite TV at home?
a. Yes
b. No 
13. If you have a satellite $T V$, which music channels do you watch most?
a. MTV
b. Kral TV
c. VH1
d. Number1 TV
e. Power Türk

f. Dream TV g. Other (please indicate:

14. You use your allowances mostly to buy:

a. Food b. Clothes c. Accessories d. Beauty products e. Books

f. Magazines g. Other (please indicate:

15. What do you plan to buy in the near future? (indicate type/brand)
a. Cell phone
d. Clothes
b. I-pod/MP3 player
e. Beauty product
c. Computer
f. Accessories
g. Book
h. Other (please indicate:

16. Is brand important for you?

a) Yes it is, because:

b) No it is not, because:

17. Height (please indicate) Weight (please indicate)

18. Have you ever been on diet to loose weight?
a) Yes
b) No

19. Are you on a diet now?
a) Yes
b) No

20. Do you plan to go on a diet in the near future to loose weight?
a) Yes
b) No

21. Which hair color is the most beautiful for a girl?
a) Own natural color
b) Blonde
c) Brunette
d) Black
e) Red
f) Other (please indicate:

22. Which eye color is the most beautiful for a girl?
a) Own natural color
b) Green
c) Blue
d) Brown
e) Other (please indicate:
-

23. Do you purchase one or more girls' magazines regularly?
a) Yes I do
b) I sometimes do
c) I only read on the Internet
d) I never purchase

24. If your answer to question 23 is (d) why don't you buy?

a) I don't buy because I am not interested

b) I don't buy because they are expensive

c) I don't buy, I read my friend's magazines

d) Instead I buy magazines for adults (Cosmopolitan, Hülya etc.)

e) I don't buy because 
25. If your answer to question 23 is yes, or sometimes, which magazine/magazines do you purchase? (You may mark more than one answer)
a) Hey Girl
b) Cosmo Girl
c) Go Girl
d) Salsa
e) Other (please indicate:

26. My parents know that I purchase magazines.
a) Yes
b) No

27. Where do you prefer to read magazines?
a) Alone in my room
b) With my friends
c) in the living room
d) Other (please indicate:

28. Which one is your best girls' magazine?
a) Hey Girl
b) Cosmo Girl
c) Go Girl
d) Salsa
e) Other (please indicate:
f) None of them

29. Have you read a girls' magazine in the last week?
a) Yes
b) No

30. Which factors are important for you in buying a magazine?
a) Cover picture
b) Promotions
c) Its contents
d) Other (please indicate:

31. When you are purchasing an item for yourself (clothes, accessories, cell phone, etc.) who/what is influential?

a) Advertisements in magazines

b) My friends or my peers

c) My family members (please indicate whom)

d) Other (please indicate:

32. Which sections do you like most in girls' magazines? Please rank from 1 to 10.
( ) Fashion
( ) Tips about boys
( ) Beauty tips
( ) Astrology
( ) Shopping tips
( ) Advertisements
( ) Interviews with celebrities
( ) Letters from readers
( ) Tests
( ) Posters
( ) Other (please indicate:

33. Which clothes appear most in your closets? Please order from most to least? ( 1 for the most, 2 for the next most, then $3, \ldots$ )

a) Jean trousers( ) b) Jean skirts( ) c) Fabric trousers( ) d) Fabric skirts( )
e) T-shirts( )
f) Shirts( )
g) Party dresses( )
h) Accessories( )
i) Other (please indicate: 
Which of the following remarks about magazines are valid for you?

34. Magazines effect my clothing positively
a. Definitely agree
b. Agree
c. Neutral
d. Don't agree
e. Definitely don't agree

35. With the tips they give, guide me in my relationships with friends
a. Definitely agree
b. Agree
c. Neutral
d. Don't agree

e. Definitely don't agree

36. Guide me in my relations with my family and my school
a. Definitely agree
b. Agree
c. Neutral
d. Don't agree
e. Definitely don’t agree

37. Guide me in my relationships with the opposite sex
a. Definitely agree
b. Agree
c. Neutral
d. Don't agree
e. Definitely don't agree

38. a Entertain me and help me forget my worries.
a. Definitely agree
b. Agree
c. Neutral
d. Don't agree
e. Definitely don’t agree

38. b My clothes look good on me as much as the clothes on models in magazines.
a. Definitely agree
b. Agree
c. Neutral
d. Don't agree
e. Definitely don't agree

39. Help me in guiding my mother or my sisters correctly when they are going to do shopping.
a. Definitely agree
b. Agree
c. Neutral
d. Don't agree
e. Definitely don't agree

40. I want to look like the girls I see on magazine cover pages.
a. Definitely agree
b. Agree
c. Neutral
d. Don't agree
e. Definitely don't agree 
The questions below are related to the degree of your satisfaction about your body parts. Please indicate your degree of satisfaction according to the following choices.
a) Very satisfied
b) Satisfied c) Neutral
d) Not satisfied
e) Not satisfied at all
41. My hair
42. My ears
43. My mouth and lips
44. My chin
45. My face beauty
46. My shoulders
47. My arms
48. My waist
49. My feet

50. The color of my skin

51. My height

52. My general look

53. My eyes

54. My nose

55. My teeth

56. Acne on my face

57. Hair on my face

58. Tone of my voice

59. My breasts

60. My hands

61. My hips

62. My legs

63. Hair on my body

64. My muscular form

65. My weight

\begin{tabular}{|c|c|c|c|}
\hline a.( ) & b. ( ) & c.( () & d.( ) \\
\hline a.( ) & b. ( ) & c. ( ) & d.( ) \\
\hline a. ( ) & b.( ) & c.( () & d.( ) \\
\hline a.( ) & b.( ) & c.( () & d.( ) \\
\hline a.( ) & b.( ) & c.( () & .( ) \\
\hline a.( ) & b.( ) & c.( () & d.( ) \\
\hline a.( ) & b.( ) & c.( () & d.( ) \\
\hline a.( ) & b.( ) & c.( ) & d.( ) \\
\hline a.( ) & b.( ) & c.( ) & d.( ) \\
\hline a.( ) & b.( ) & c.( ) & d.( ) \\
\hline a.( ) & b.( ) & c.( ) & d.( ) \\
\hline a.( ) & b.( ) & c.( ) & d.( ) \\
\hline a.( ) & b.( ) & c.( ) & d.( ) \\
\hline a.( ) & b.( ) & c.( ) & d.( ) \\
\hline a.( ) & b.( ) & c.( ) & d.( ) \\
\hline a.( ) & b.( ) & c.( () & d.( ) \\
\hline a.( ) & b.( ) & c.( ) & d.( ) \\
\hline a.( ) & b.( ) & c.( ) & d.( ) \\
\hline a.( ) & b.( ) & c.( ) & d.( ) \\
\hline a.( ) & b.( ) & c.( () & d.( ) \\
\hline a.( () & b.( ) & c.( () & d.( () \\
\hline a.( ) & b.( ) & c.( () & d.( ) \\
\hline a.( ) & b.( ) & c.( () & d.( ) \\
\hline a.( ) & b.( ) & c.( () & d.( ) \\
\hline a.( () & b. () & c.( () & d. () \\
\hline
\end{tabular}

66. Your school :

67. Your performance at school: a. Very good b. Good c. Medium d. Weak

Thank you very much for answering the questions...

\author{
Yonca Aybay \\ Eastern Mediterranean University \\ Faculty of Communication, Ph. D. student
}

Tel: (392) 6301296 


\section{Appendix B: Content Analysis Graphs and Tables}

Table B1. Number and percentage of pages according to categories (Hey Girl)

\begin{tabular}{|c|c|c|c|c|c|c|c|c|c|c|c|c|c|c|c|c|c|c|}
\hline MAG & YEAR & MONTH & pgs & fash & beaut & celeb & sex & music & sport & diet & editor & astro & educ & shop & reader & adv & tech & other \\
\hline HG & 2007 & 1 & 100.00 & 3.00 & 3.00 & 23.00 & 16.00 & 0.00 & 3.00 & 2.00 & 4.00 & 2.00 & 7.00 & 24.00 & 1.00 & 11.00 & 0.00 & 1.00 \\
\hline HG & 2007 & 9 & 118.00 & 2.00 & 4.00 & 21.00 & 21.00 & 2.00 & 1.00 & 2.00 & 5.00 & 2.00 & 3.00 & 26.00 & 0.00 & 26.00 & 0.00 & 3.00 \\
\hline HG & 2007 & 11 & 118.00 & 1.00 & 2.00 & 15.00 & 22.00 & 0.00 & 2.00 & 2.00 & 12.00 & 2.00 & 2.00 & 26.00 & 1.00 & 30.00 & 0.00 & 1.00 \\
\hline HG & 2008 & 6 & 116.00 & 0.00 & 5.00 & 21.00 & 11.00 & 3.00 & 1.00 & 2.00 & 5.00 & 4.00 & 2.00 & 28.00 & 1.00 & 33.00 & 0.00 & 0.00 \\
\hline HG & 2008 & 9 & 100.00 & 0.00 & 8.00 & 7.00 & 31.00 & 2.00 & 2.00 & 2.00 & 5.00 & 2.00 & 3.00 & 17.00 & 1.00 & 20.00 & 0.00 & 0.00 \\
\hline HG & 2009 & 2 & 100.00 & 1.00 & 3.00 & 14.00 & 20.00 & 2.00 & 2.00 & 2.00 & 3.00 & 2.00 & 4.00 & 27.00 & 1.00 & 19.00 & 0.00 & 0.00 \\
\hline HG & 2009 & 8 & 100.00 & 1.00 & 0.00 & 17.00 & 24.00 & 2.00 & 2.00 & 2.00 & 11.00 & 2.00 & 0.00 & 21.00 & 1.00 & 17.00 & 0.00 & 0.00 \\
\hline HG & 2010 & 4 & 100.00 & 1.00 & 2.00 & 22.00 & 20.00 & 0.00 & 0.00 & 2.00 & 4.00 & 2.00 & 2.00 & 20.00 & 1.00 & 24.00 & 0.00 & 0.00 \\
\hline HG & 2010 & 1 & 100.00 & 1.00 & 1.00 & 15.00 & 15.00 & 4.00 & 2.00 & 4.00 & 5.00 & 2.00 & 3.00 & 33.00 & 1.00 & 14.00 & 0.00 & 0.00 \\
\hline HG & 2010 & 12 & 100.00 & 0.00 & 1.00 & 14.00 & 17.00 & 4.00 & 2.00 & 0.00 & 5.00 & 2.00 & 4.00 & 29.00 & 0.00 & 19.00 & 1.00 & 2.00 \\
\hline AVG & & & 105.8 & 1.00 & 4.17 & 16.33 & 18.58 & 1.92 & 1.75 & 2.00 & 5.58 & 2.33 & 3.58 & 24.42 & 1.08 & 22.42 & 0.08 & 0.58 \\
\hline PCT & & & 100 & 0.94 & 3.94 & 15.43 & 17.56 & 1.81 & 1.65 & 1.89 & 5.28 & 2.20 & 3.39 & 23.07 & 1.02 & 21.18 & 0.08 & 0.55 \\
\hline
\end{tabular}


Table B2. Number and percentage of pages according to categories (Cosmo Girl Magazine)

\begin{tabular}{|c|c|c|c|c|c|c|c|c|c|c|c|c|c|c|c|c|c|c|}
\hline MAG & YEAR & MONTH & PAGE & fash & beau & celeb & sex & music & sport & diet & edito & astro & educ & shop & reader & adv & tech & other \\
\hline CG & 2007 & 1 & 136.00 & 2.00 & 1.00 & 39.00 & 15.00 & 2.00 & 1.00 & 2.00 & 6.00 & 3.00 & 3.00 & 45.00 & 1.00 & 14.00 & 0.00 & 2.00 \\
\hline CG & 2007 & 9 & 148.00 & 8.00 & 7.00 & 26.00 & 15.00 & 12.00 & 6.00 & 2.00 & 5.00 & 4.00 & 4.00 & 19.00 & 2.00 & 33.00 & 0.00 & 5.00 \\
\hline CG & 2007 & 11 & 134.00 & 11.00 & 3.00 & 15.00 & 13.00 & 14.00 & 5.00 & 2.00 & 6.00 & 2.00 & 7.00 & 30.00 & 0.00 & 25.00 & 0.00 & 1.00 \\
\hline CG & 2008 & 6 & 132.00 & 2.00 & 10.00 & 18.00 & 13.00 & 8.00 & 1.00 & 2.00 & 4.00 & 2.00 & 4.00 & 34.00 & 6.00 & 23.00 & 0.00 & 5.00 \\
\hline CG & 2008 & 9 & 134.00 & 0.00 & 1.00 & 19.00 & 19.00 & 7.00 & 7.00 & 9.00 & 5.00 & 2.00 & 2.00 & 35.00 & 8.00 & 17.00 & 0.00 & 3.00 \\
\hline CG & 2009 & 2 & 100.00 & 2.00 & 0.00 & 25.00 & 8.00 & 7.00 & 0.00 & 2.00 & 4.00 & 1.00 & 6.00 & 19.00 & 5.00 & 21.00 & 0.00 & 0.00 \\
\hline CG & 2009 & 8 & 100.00 & 2.00 & 4.00 & 15.00 & 22.00 & 5.00 & 1.00 & 3.00 & 3.00 & 1.00 & 1.00 & 21.00 & 3.00 & 19.00 & 0.00 & 0.00 \\
\hline CG & 2010 & 1 & 116.00 & 2.00 & 6.00 & 33.00 & 13.00 & 7.00 & 3.00 & 1.00 & 6.00 & 1.00 & 0.00 & 30.00 & 0.00 & 14.00 & 0.00 & 0.00 \\
\hline CG & 2010 & 4 & 100.00 & 2.00 & 1.00 & 17.00 & 10.00 & 4.00 & 3.00 & 1.00 & 5.00 & 1.00 & 6.00 & 30.00 & 1.00 & 18.00 & 0.00 & 1.00 \\
\hline CG & 2010 & 12 & 100.00 & 3.00 & 2.00 & 17.00 & 6.00 & 1.00 & 2.00 & 1.00 & 7.00 & 1.00 & 0.00 & 35.00 & 1.00 & 24.00 & 0.00 & 0.00 \\
\hline AVG & & & 120.67 & 3.42 & 3.42 & 21.00 & 13.42 & 6.92 & 2.92 & 2.58 & 5.00 & 1.75 & 3.08 & 30.33 & 3.17 & 21.25 & 0.00 & 2.42 \\
\hline PCT & & & 100 & 2.83 & 2.83 & 17.4 & 11.1 & 5.73 & 2.42 & 2.1 & 4.14 & 1.45 & 2.56 & 25.1 & 2.62 & 17.6 & $\mathbf{0}$ & 2 \\
\hline
\end{tabular}


Table B3. Overall percentage of pages according to categories

\begin{tabular}{|c|c|c|c|c|c|c|c|c|c|c|c|c|c|c|c|c|c|c|}
\hline mg & Year & no & Fash & eauty & Celeb & sex & music & sport & diet & edit & astro & educ & shop & rder & adv & tech & other & total \\
\hline $\mathrm{HG}$ & 2007 & 1 & 3.00 & 3.00 & 23.00 & 16.00 & 0.00 & 3.00 & 2.00 & 4.00 & 2.00 & 7.00 & 24.00 & 1.00 & 11.00 & 0.00 & 1.00 & 100.00 \\
\hline HG & 2007 & 9 & 1.69 & 3.39 & 17.80 & 17.80 & 1.69 & 0.85 & 1.69 & 4.24 & 1.69 & 2.54 & 22.03 & 0.00 & 22.03 & 0.00 & 2.54 & 100.00 \\
\hline $\mathrm{HG}$ & 2007 & 11 & 0.85 & 1.69 & 12.71 & 18.64 & 0.00 & 1.69 & 1.69 & 10.17 & 1.69 & 1.69 & 22.03 & 0.85 & 25.42 & 0.00 & 0.85 & 100.00 \\
\hline $\mathrm{CG}$ & 2007 & 1 & .47 & 0.74 & 28.68 & 11.03 & 1.47 & 0.74 & 1.47 & 4.41 & 2.21 & 2.21 & 33.09 & 0.74 & 10.29 & 0.00 & 1.47 & 100.00 \\
\hline $\mathrm{CG}$ & 2007 & 9 & 5.41 & 4.73 & 17.57 & 10.14 & 8.11 & 4.05 & 1.35 & 3.38 & 2.70 & 2.70 & 12.84 & 1.35 & 22.30 & 0.00 & 3.38 & 100.00 \\
\hline CG & 2007 & 11 & 8.21 & 2.24 & 11.19 & 9.70 & 10.45 & 3.73 & 1.49 & 4.48 & 1.49 & 5.22 & 22.39 & 0.00 & 18.66 & 0.00 & 0.75 & 100.00 \\
\hline $\mathrm{HG}$ & 2009 & 2 & 1.00 & 3.00 & 14.00 & 20.00 & 2.00 & 2.00 & 2.00 & 3.00 & 2.00 & 4.00 & 27.00 & 1.00 & 19.00 & 0.00 & 0.00 & 100.00 \\
\hline $\mathrm{HG}$ & 2009 & 5 & & 5.00 & 7.00 & 14.00 & 4.00 & 2.00 & 2.00 & 5.00 & 2.00 & 3.00 & 23.00 & 3.00 & 29.00 & 0.00 & 0.00 & 100.00 \\
\hline $\mathrm{HG}$ & 2009 & 8 & 1.00 & 0.00 & 17.00 & 24.00 & 2.00 & 2.00 & 2.00 & 11.00 & 2.00 & 0.00 & 21.00 & 1.00 & 17.00 & 0.00 & 0.00 & 100.00 \\
\hline $\mathrm{CG}$ & 2009 & 2 & 2.00 & 0.00 & 25.00 & 8.00 & 7.00 & 0.00 & 2.00 & 4.00 & 1.00 & 6.00 & 19.00 & 5.00 & 21.00 & 0.00 & 0.00 & 100.00 \\
\hline $\mathrm{CG}$ & 2009 & 5 & & 4.31 & 7.76 & 9.48 & 8.62 & 2.59 & 0.86 & 4.31 & 0.86 & 1.72 & 30.17 & 4.31 & 24.14 & 0.00 & 0.86 & 100.00 \\
\hline $\mathrm{CG}$ & 2009 & 8 & 2.00 & 4.00 & 15.00 & 22.00 & 5.00 & 1.00 & 3.00 & 3.00 & 1.00 & 1.00 & 21.00 & 3.00 & 19.00 & 0.00 & 0.00 & 100.00 \\
\hline $\mathrm{HG}$ & 2008 & 3 & 0.85 & 13.56 & 16.95 & 10.17 & 0.00 & 1.69 & 1.69 & 2.54 & 3.39 & 8.47 & 16.10 & 1.69 & 22.88 & 0.00 & 0.00 & 100.00 \\
\hline $\mathrm{HG}$ & 2008 & 6 & 0.00 & 4.31 & 18.10 & 9.48 & 2.59 & 0.86 & 1.72 & 4.31 & 3.45 & 1.72 & 24.14 & 0.86 & 28.45 & 0.00 & 0.00 & 100.00 \\
\hline $\mathrm{HG}$ & 2008 & 9 & 0.00 & 8.00 & 7.00 & 31.00 & 2.00 & 2.00 & 2.00 & 5.00 & 2.00 & 3.00 & 17.00 & 1.00 & 20.00 & 0.00 & 0.00 & 100.00 \\
\hline $\mathrm{CG}$ & 2008 & 3 & 5.30 & 0.76 & 14.39 & 12.12 & 4.55 & 2.27 & 3.79 & 3.03 & 1.52 & 1.52 & 23.48 & 4.55 & 14.39 & 0.00 & 8.33 & 100.00 \\
\hline CG & 2008 & 6 & 1.52 & 7.58 & 13.64 & 9.85 & 6.06 & 0.76 & 1.52 & 3.03 & 1.52 & 3.03 & 25.76 & 4.55 & 17.42 & 0.00 & 3.79 & 100.00 \\
\hline $\mathrm{CG}$ & 2008 & 9 & 0.00 & 0.75 & 14.18 & 14.18 & 5.22 & 5.22 & 6.72 & 3.73 & 1.49 & 1.49 & 26.12 & 5.97 & 12.69 & 0.00 & 2.24 & 100.00 \\
\hline $\mathrm{HG}$ & 2010 & 4 & 1.00 & 2.00 & 22.00 & 20.00 & 0.00 & 0.00 & 2.00 & 4.00 & 2.00 & 2.00 & 20.00 & 1.00 & 24.00 & 0.00 & 0.00 & 100.00 \\
\hline $\mathrm{HG}$ & 2010 & 1 & 1.00 & 1.00 & 15.00 & 15.00 & 4.00 & 2.00 & 4.00 & 5.00 & 2.00 & 3.00 & 33.00 & 1.00 & 14.00 & 0.00 & 0.00 & 100.00 \\
\hline $\mathrm{HG}$ & 2010 & 12 & 0.00 & 1.00 & 14.00 & 17.00 & 4.00 & 2.00 & 0.00 & 5.00 & 2.00 & 4.00 & 29.00 & 0.00 & 19.00 & 1.00 & 2.00 & 100.00 \\
\hline CG & 2010 & 1 & 1.72 & 5.17 & 28.45 & 11.21 & 6.03 & 2.59 & 0.86 & 5.17 & 0.86 & 0.00 & 25.86 & 0.00 & 12.07 & 0.00 & 0.00 & 100.00 \\
\hline $\mathrm{CG}$ & 2010 & 4 & 2.00 & 1.00 & 17.00 & 10.00 & 4.00 & 3.00 & 1.00 & 5.00 & 1.00 & 6.00 & 30.00 & 1.00 & 18.00 & 0.00 & 1.00 & 100.00 \\
\hline $\mathrm{CG}$ & 2010 & 12 & 3.00 & 2.00 & 17.00 & 6.00 & 1.00 & 2.00 & 1.00 & 7.00 & 1.00 & 0.00 & 35.00 & 1.00 & 24.00 & 0.00 & 0.00 & 100.00 \\
\hline AV & & & 1.83 & 3.30 & 16.43 & 14.45 & 3.74 & 2.00 & 1.99 & 4.74 & 1.79 & 2.97 & 24.29 & 1.83 & 19.41 & 0.04 & 1.18 & 100.00 \\
\hline
\end{tabular}


Table B4. Clothes and accessories appearing in magazines 2010 (issues 1, 4 and 12)

\begin{tabular}{|l|r|r|r|r|r|r|r|r|}
\hline \multicolumn{1}{|c|}{ Type } & \multicolumn{1}{|c|}{ CG-1 } & HG-1 & CG-4 & HG-4 & \multicolumn{1}{c|}{$\begin{array}{c}\text { CG- } \\
\mathbf{1 2}\end{array}$} & $\begin{array}{c}\text { HG- } \\
\mathbf{1 2}\end{array}$ & Total & Rank \\
\hline $\begin{array}{l}\text { Jean } \\
\text { trousers }\end{array}$ & 23 & 33 & 21 & 12 & 23 & 23 & 135 & $\mathbf{2}$ \\
\hline Jean skirts & 0 & 1 & 1 & 3 & 2 & 0 & 5 & $\mathbf{7}$ \\
\hline T-shirts & 29 & 28 & 32 & 32 & 21 & 50 & 160 & $\mathbf{1}$ \\
\hline $\begin{array}{l}\text { Fabric } \\
\text { trousers }\end{array}$ & 1 & 1 & 2 & 1 & 3 & 1 & 9 & $\mathbf{6}$ \\
\hline $\begin{array}{l}\text { Fabric } \\
\text { skirts }\end{array}$ & 3 & 1 & 4 & 0 & 3 & 0 & 11 & $\mathbf{5}$ \\
\hline $\begin{array}{l}\text { Shirts } \\
\text { Party } \\
\text { dresses }\end{array}$ & 9 & 7 & 10 & 14 & 7 & 0 & 47 & $\mathbf{4}$ \\
\hline
\end{tabular}




\begin{tabular}{|c|c|c|c|c|c|c|c|c|c|c|c|c|c|c|c|c|c|c|c|}
\hline \multirow{11}{*}{ 䠶 } & & \multirow{2}{*}{ Table B5. } & \multirow[b]{2}{*}{ Fsh } & \multirow[b]{2}{*}{ Bty } & \multirow[b]{2}{*}{ Tec } & \multicolumn{8}{|c|}{ Traditional and feminist messages in advertisements } & \multirow[b]{2}{*}{ Plce } & \multirow[b]{2}{*}{ musc } & \multirow[b]{2}{*}{ Crd } & \multirow[b]{2}{*}{ hous } & \multirow[b]{2}{*}{ tot iss } & \multirow[b]{2}{*}{ Totall } \\
\hline & & & & & & $\mathrm{Je}$ & Stnr & Foo & Medi & Acs & Univ & Edu & Med & & & & & & \\
\hline & \multirow{3}{*}{1} & None & 1 & 0 & 3 & 0 & 1 & 3 & 3 & 0 & 0 & 0 & 0 & 0 & 0 & 0 & 0 & 11 & 213 \\
\hline & & Feminist & 0 & 0 & 0 & 0 & 0 & 0 & 0 & 0 & 0 & 0 & 0 & 0 & 0 & 0 & 0 & 0 & 13 \\
\hline & & Traditionl & 8 & 6 & 1 & 0 & 0 & 0 & 1 & 0 & 0 & 0 & 0 & 0 & 0 & 0 & 0 & 16 & 516 \\
\hline & \multirow{3}{*}{9} & None & 3 & 0 & 1 & 0 & 0 & 0 & 3 & 1 & 1 & 1 & 0 & 0 & 0 & 0 & 0 & 10 & \\
\hline & & Feminist & 1 & 0 & 0 & 0 & 0 & 0 & 0 & 1 & 0 & 1 & 0 & 0 & 0 & 0 & 0 & 3 & \\
\hline & & Traditionl & 8 & 5 & 3 & 0 & 0 & 0 & 5 & 0 & 0 & 0 & 0 & 0 & 0 & 0 & 0 & 21 & \\
\hline & \multirow{3}{*}{11} & None & 3 & 1 & 1 & 1 & 0 & 0 & 0 & 0 & 0 & 0 & 0 & 0 & 0 & 0 & 0 & 6 & \\
\hline & & Feminist & 0 & 0 & 0 & 0 & 0 & 0 & 0 & 0 & 0 & 0 & 0 & 0 & 0 & 0 & 0 & 0 & \\
\hline & & Traditionl & 4 & 11 & 1 & 2 & 0 & 0 & 0 & 0 & 0 & 0 & 0 & 0 & 0 & 0 & 0 & 18 & \\
\hline \multirow{9}{*}{ 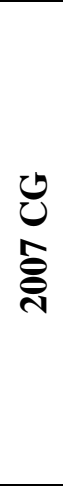 } & \multirow{3}{*}{1} & None & 0 & 1 & 0 & 0 & 0 & 0 & 2 & 0 & 0 & 0 & 0 & 0 & 0 & 0 & 0 & 3 & \\
\hline & & Feminist & 0 & 0 & 0 & 0 & 0 & 0 & 0 & 0 & 0 & 0 & 0 & 0 & 0 & 0 & 0 & 0 & \\
\hline & & Traditionl & 18 & 5 & 0 & 0 & 0 & 0 & 2 & 1 & 0 & 0 & 0 & 0 & 0 & 0 & 0 & 26 & \\
\hline & \multirow{3}{*}{9} & None & 3 & 3 & 1 & 0 & 1 & 1 & 2 & 0 & 0 & 0 & 0 & 0 & 0 & 0 & 0 & 11 & \\
\hline & & Feminist & 1 & 0 & 0 & 0 & 0 & 0 & 0 & 0 & 0 & 0 & 0 & 0 & 0 & 0 & 0 & 1 & \\
\hline & & Traditionl & 17 & 18 & 1 & 0 & 2 & 1 & 0 & 0 & 0 & 0 & 0 & 0 & 0 & 0 & 0 & 39 & \\
\hline & \multirow{3}{*}{11} & None & 14 & 6 & 1 & 0 & 0 & 1 & 0 & 2 & 0 & 0 & 0 & 0 & 0 & 0 & 0 & 24 & \\
\hline & & Feminist & 2 & 0 & 0 & 0 & 0 & 0 & 0 & 0 & 0 & 0 & 0 & 0 & 0 & 0 & 0 & 2 & \\
\hline & & Traditionl & 19 & 5 & 0 & 0 & 0 & 0 & 0 & 1 & 0 & 0 & 1 & 0 & 0 & 0 & 0 & 26 & \\
\hline \multirow{6}{*}{ 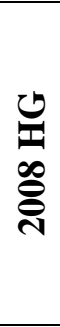 } & \multirow{3}{*}{3} & None & 2 & 0 & 1 & 0 & 0 & 1 & 2 & 0 & 0 & 0 & 0 & 0 & 0 & 0 & 0 & 6 & \\
\hline & & Feminist & 1 & 0 & 0 & 0 & 0 & 0 & 0 & 0 & 0 & 0 & 0 & 0 & 0 & 0 & 0 & 1 & \\
\hline & & Traditionl & 12 & 1 & 0 & 0 & 0 & 1 & 2 & 3 & 0 & 0 & 0 & 0 & 0 & 0 & 0 & 19 & \\
\hline & \multirow{3}{*}{6} & None & 0 & 1 & 0 & 0 & 0 & 1 & 1 & 0 & 0 & 0 & 0 & 1 & 0 & 0 & 0 & 4 & \\
\hline & & Feminist & 0 & 0 & 0 & 0 & 0 & 0 & 0 & 0 & 0 & 0 & 0 & 0 & 0 & 0 & 0 & 0 & \\
\hline & & Traditionl & 20 & 2 & 6 & 1 & 0 & 1 & 3 & 0 & 0 & 0 & 0 & 0 & 0 & 0 & 0 & 33 & \\
\hline
\end{tabular}




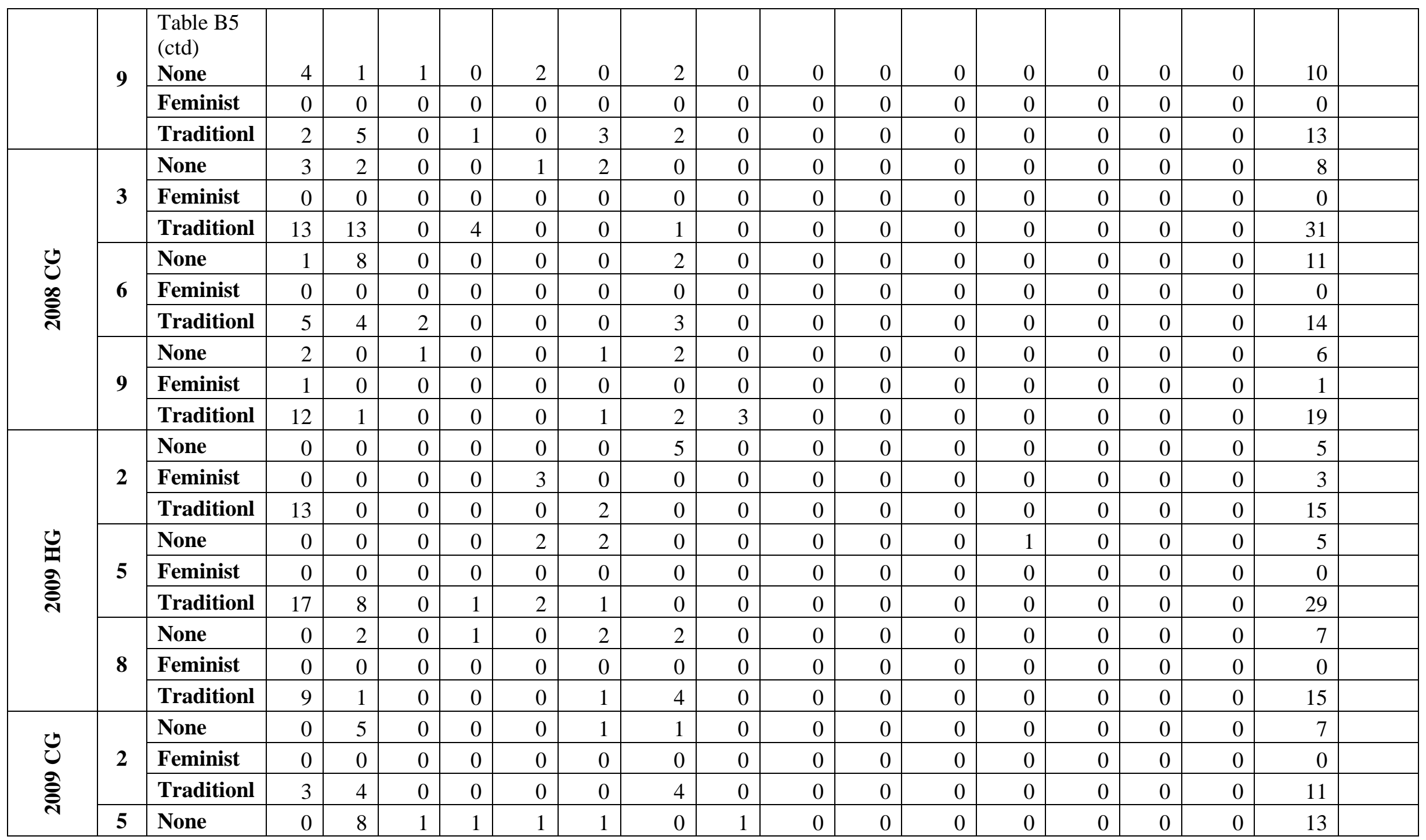




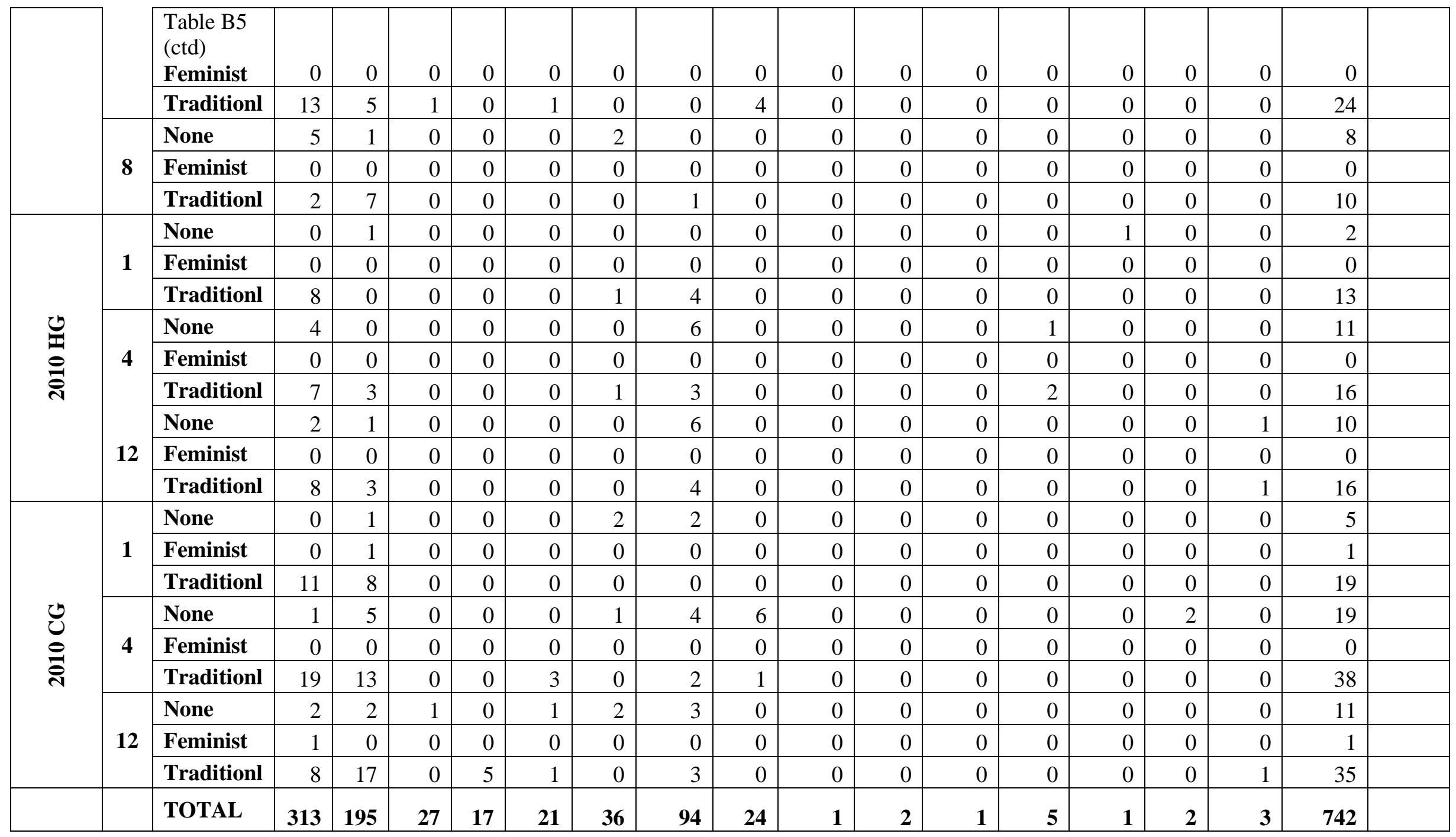





\section{Appendix C: Content Analysis Sample Pages}

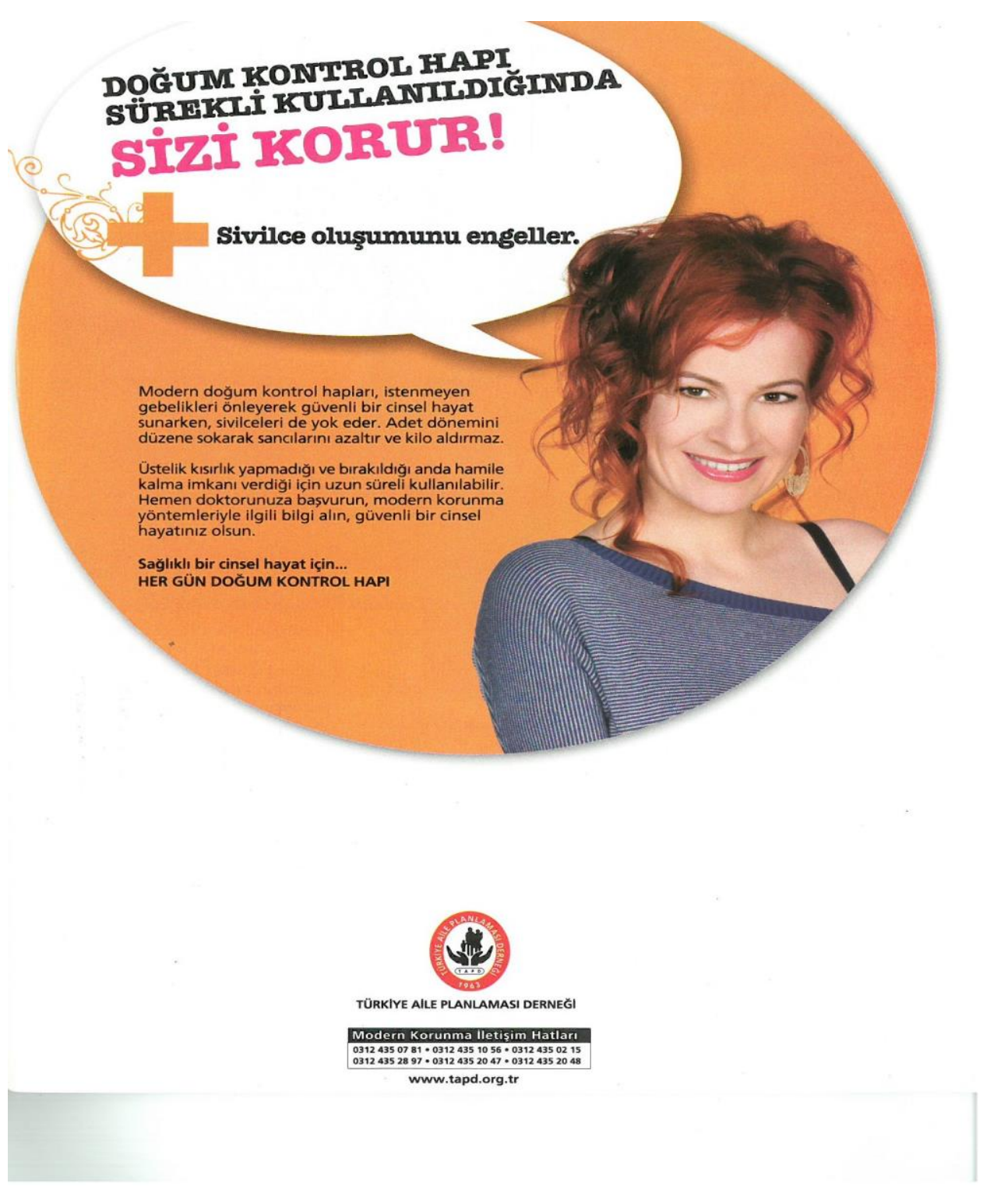

Cosmo Girl September 2007 issue, p. 63

(Also appears in Hey Girl September 2007 issue, p. 65) 


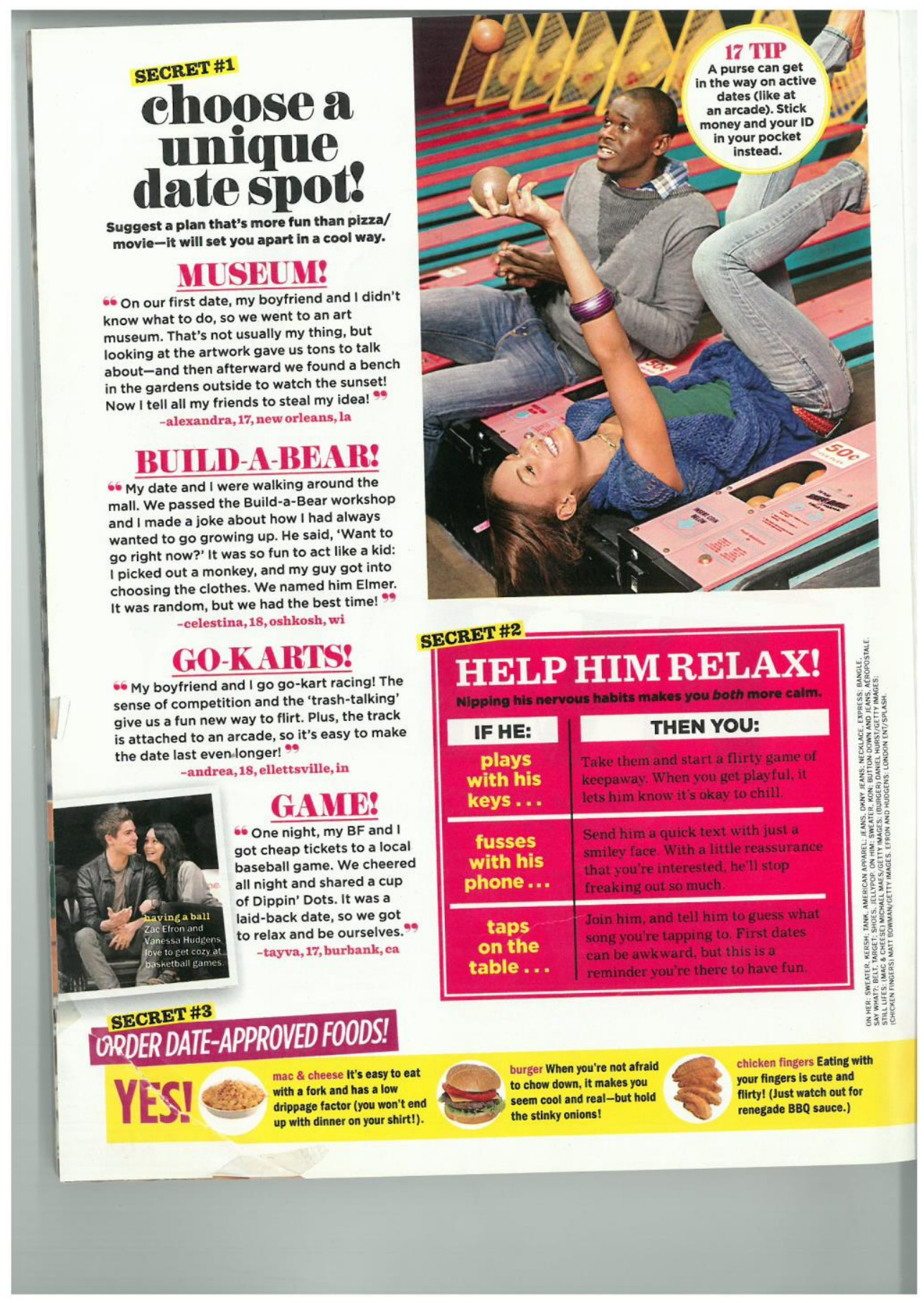

Seventeen, September 2010 issue 


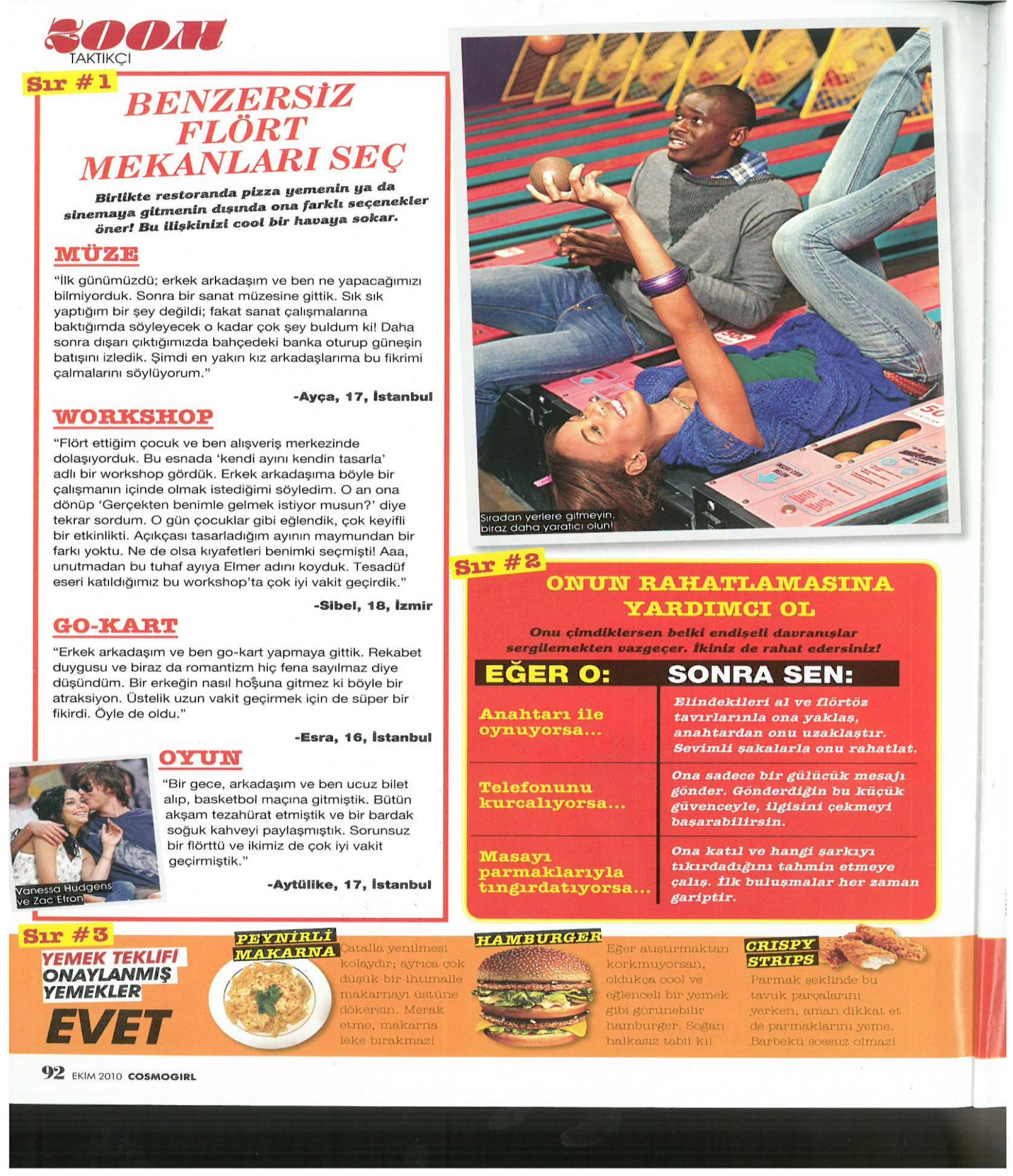

Cosmo Girl, October 2010 issue 


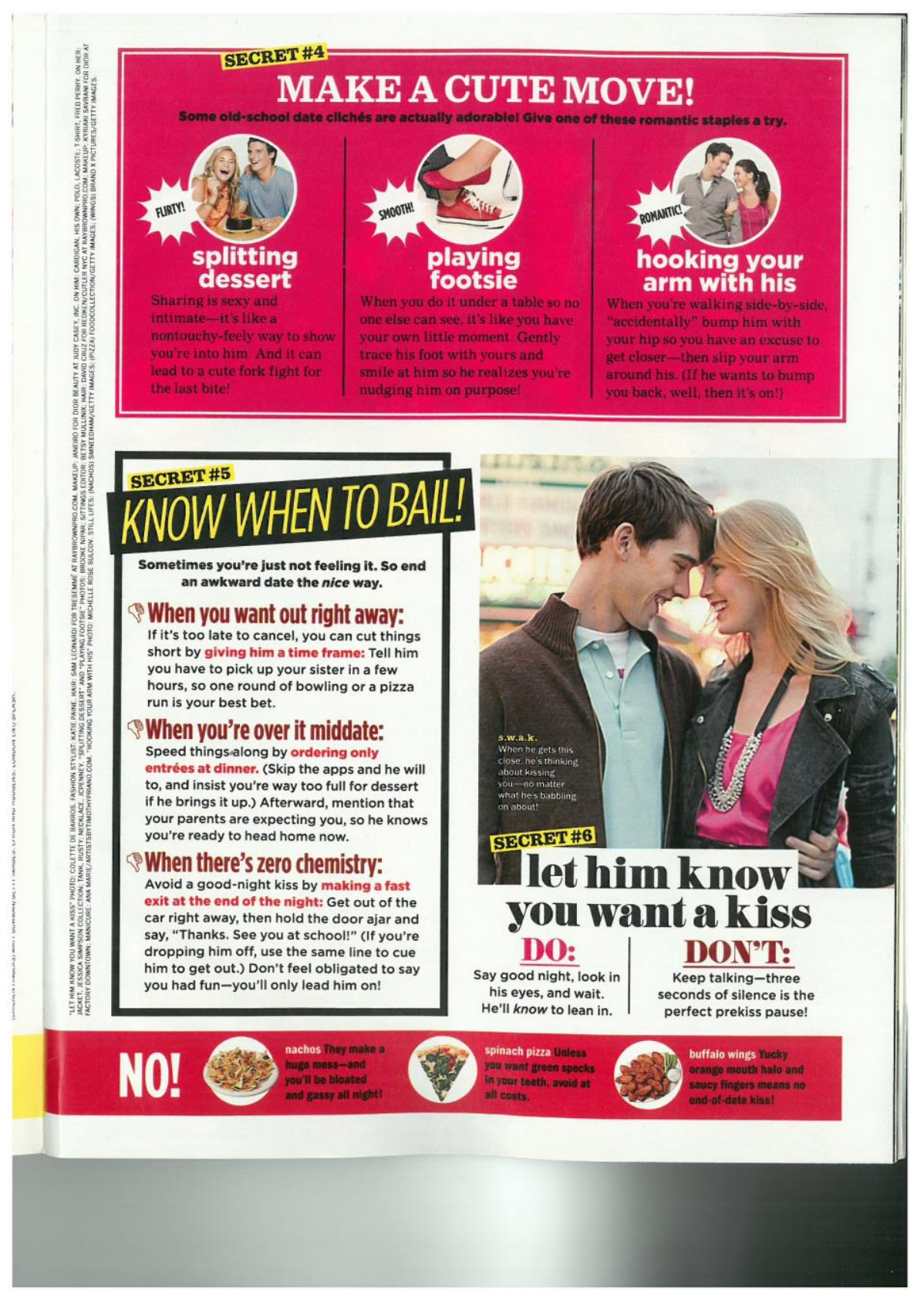

Seventeen, September 2010 issue 


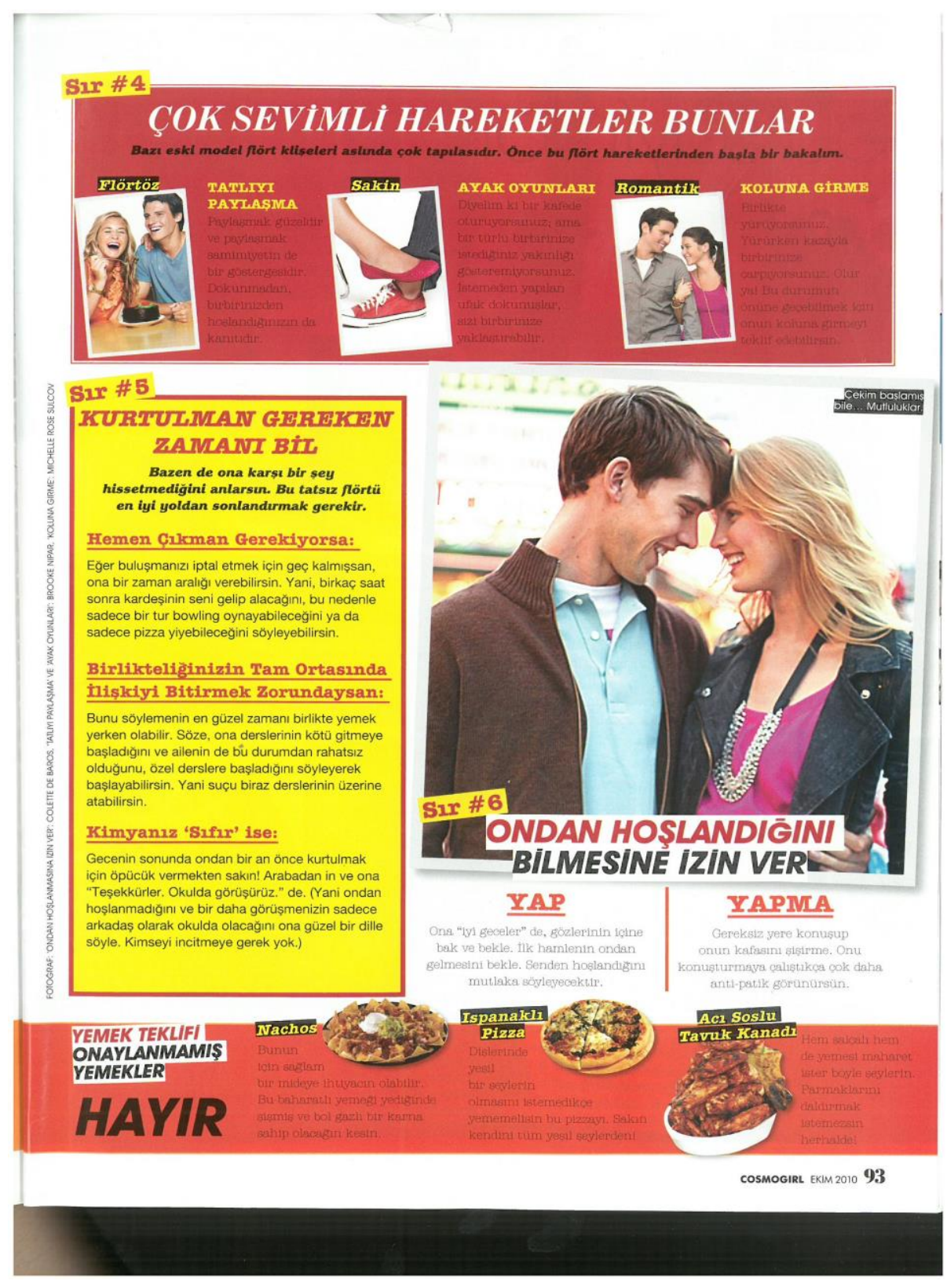

\section{Cosmo Girl, October 2010 issue}




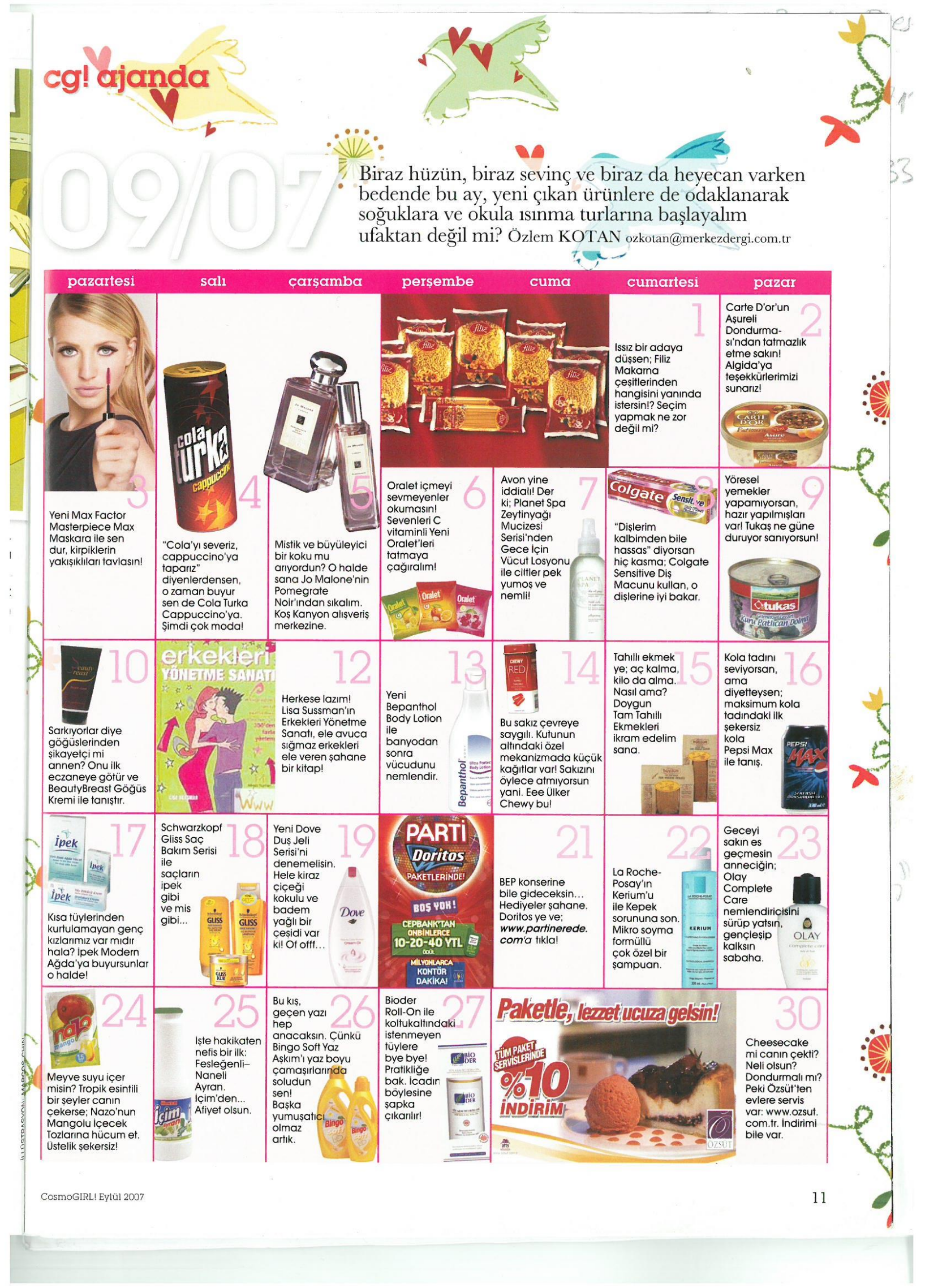



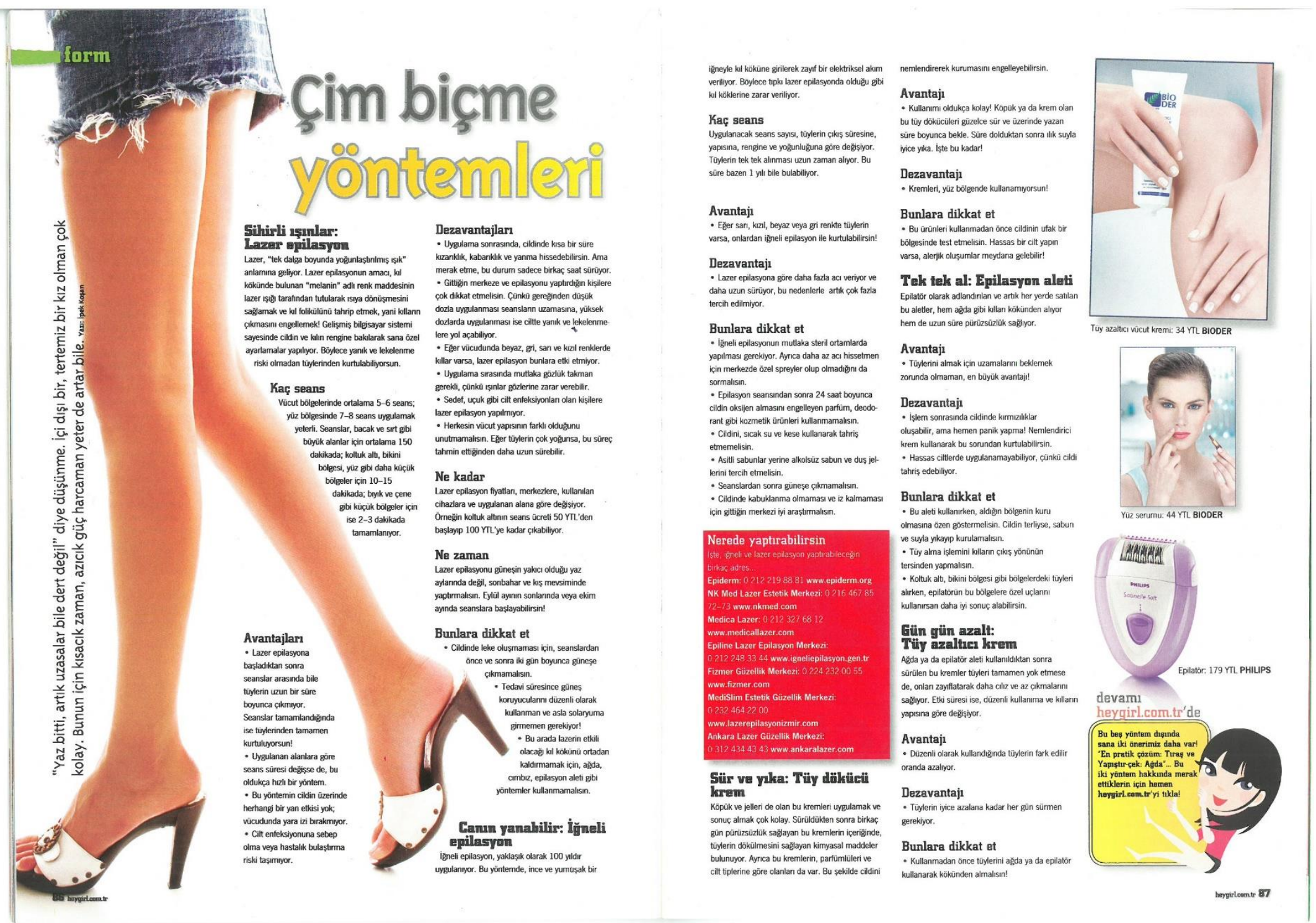


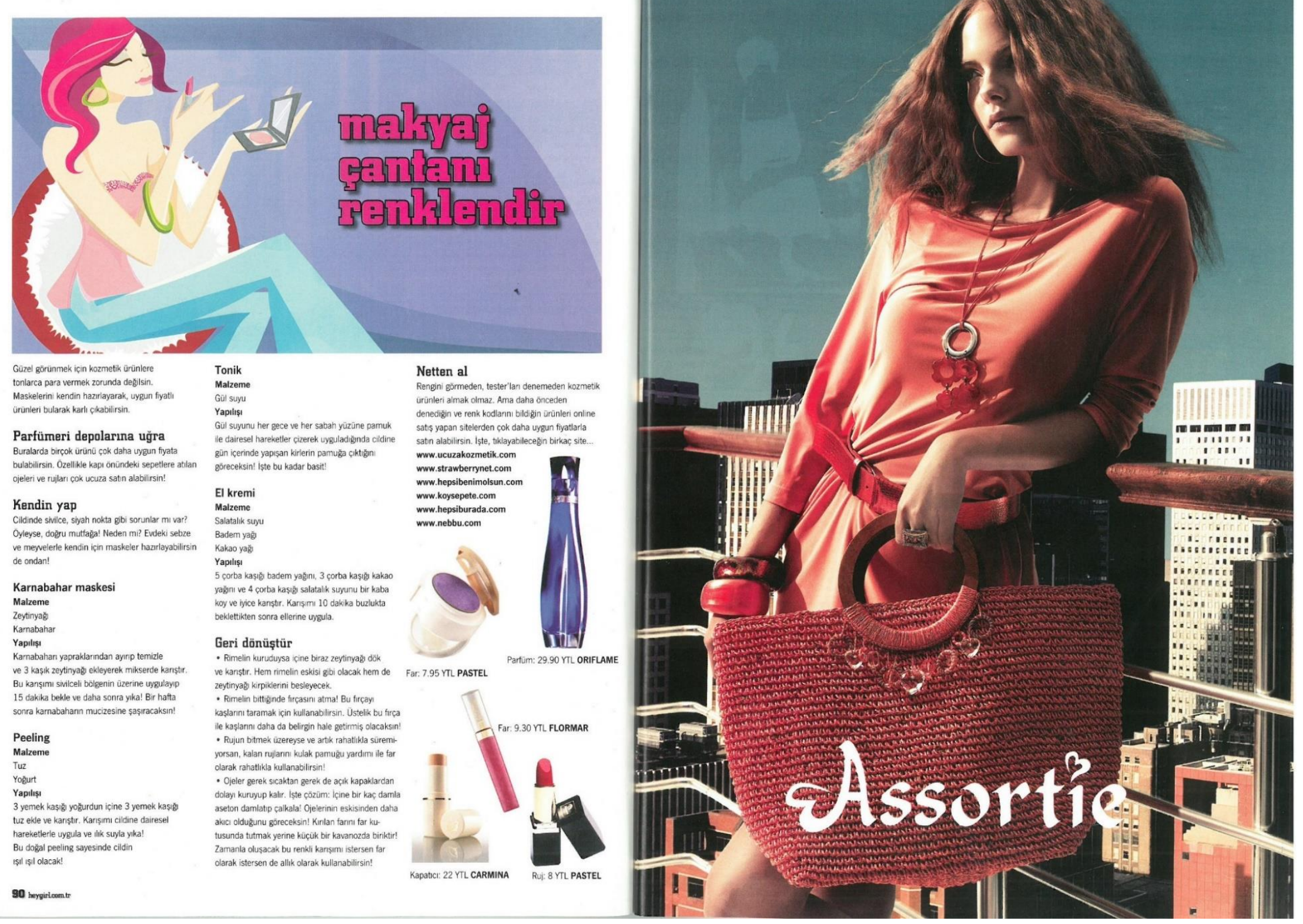




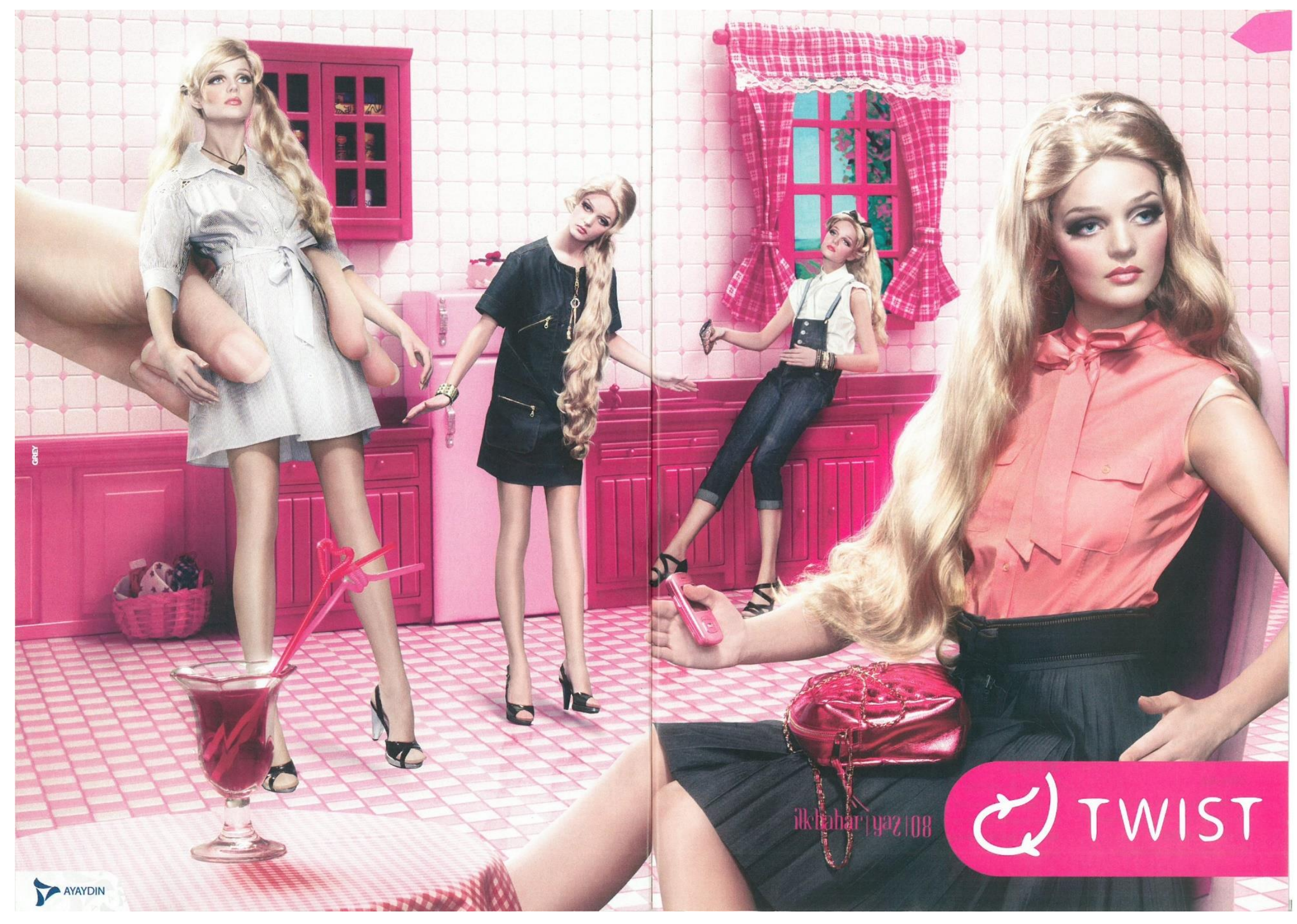


Ailelerin hayatını kolaylaştıran bir yenilik:

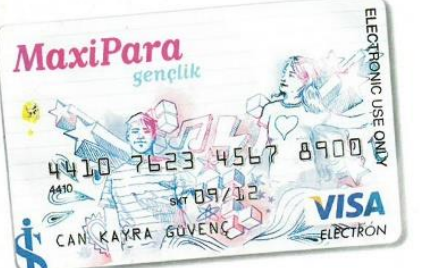

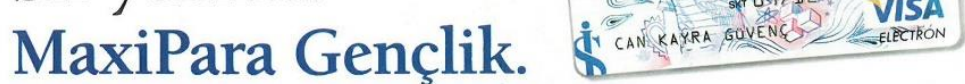

Çocuğunuza verdiğiniz harçlı̆̆ düzenli olarak takip etmek ve ona kendi bütçesini idare etme bilinci kazandırmak istiyorsanız İs Bankası'nın gençlere özel sunduğu MaxiPara

Gençlik Kart tam size göre.. MaxiPara Gençlik Kartlarla çocuğunuz yurtiçinde ve yurtdışında, yatırdığııız miktar kadarım

harcayabiliyor,

tercih etmeniz halinde nakit çekebiliyor.

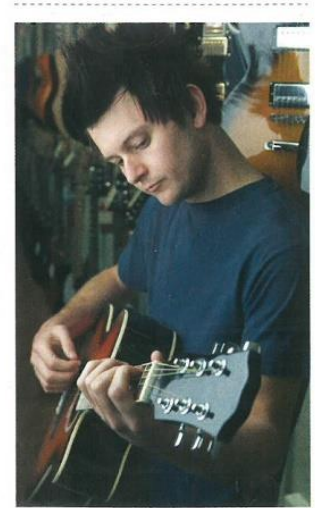

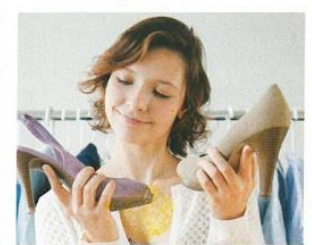

Sizin için kolaylık, çocuğunuz için güvenlik.

MaxiPara Gençlik Kart, çocugunuzu para taşıma oluyor. Kartyla alısveris yapiyor kendi sifresini kullanarak ihtiyacı olduğ anda ihtiyacı kadar para çekiyor. Hem parasız kalma korkusu yaşamıyo hem de para kaybetmek ya caldırmak gibi riskler taşımıyor.

Size en yakın şubemize gelerek çocugunuz için bir Maxi tedinebilirsiniz.

Ayruntılı bilgi için:
Düzenli para

yükleme.

Dilerseniz

belirleyeceğiniz

karttaki para

azaldığında MaxiPara

Gençlik Kart'a

otomatik para

yukleme talimatı

Boylece, çocuğunuz

sehir dişnda

harclinin

tam zamanınd

yatırdığııızdan

emin olabilirsiniz.

Ustelik, karta

para yatirabile

belirleyebilirsinz.

siniz

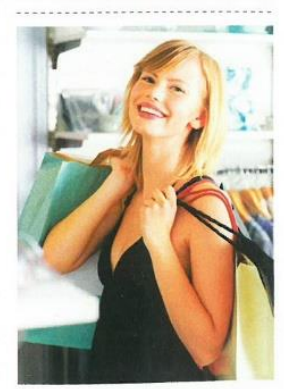

Harçlk istemekten sikıldıysan yandaki ilanı ailenin okuduğu dergiye yapıştır.
Nakit paranın yerini MaxiPara alıyor! Artık harçlıklar MaxiPara Gençlik Kart'a yatıyor, para yerine MaxiPara kullaniliyor.
MaxiPara

44007623456 ? 8900 ? (440) 


\section{KUZEY KIBRIS TÜRK CUMHURIYYETI MILLLİ EĞİTIM VE KÜLTÜR BAKANLIĞI GENEL ORTAÖĞRETIM DAİRESI MÜDÜRLÜĞÜ}

Sayı: GOÖ.0.00-35/07/08/A-6.59

07.03.2008

Sayın Yonca Aybay, Doğu Akdeniz Üniversitesi Gazi Mağusa.

İgi: 07.03 .2008 tarihli yazını.

İlgi başvurunuz Talim ve Terbiye Dairesi tarafından incelenmiş olup Müdürlüğümüze bağlı okullarda öğrenim gören öğrencilere yönelik hazırlanan "Magazin Dergilerinin Etkilerinin İncelenmesi” konulu anket sorularının uygulanması uygun görülmüştür.

Ancak anketi uygulamadan önce, anketin uygulanacağı okulun bağlı bulunduğu Müdürlükle istişarede bulunulup, anketin ne zaman uygulanacağının birlikte saptanması gerekmektedir.

Anketi uyguladıktan sonra ise sonuçlarının Talim ve Terbiye Dairesi Müdürlüğ̈u’ne ulaştırması gerektiğini bilgilerinize saygı ile rica ederim.

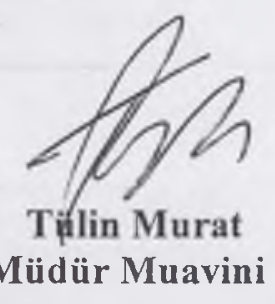

TM/PC

\begin{tabular}{lrl}
\hline Tel & $(90)(392) 2283136-2288187$ & \\
Fax & $(90)(392) 2278639$ & \\
E-mail & meb@mebnet.net & Lefkosa-KIBRIS
\end{tabular}

